KAREN STEPONAVICIUS PIEDADE CRUZ

\title{
INTERAÇÕES CELULARES EM AMBIENTE TRIDIMENSIONAL ENTRE CÉLULAS HÍBRIDAS DENDRÍTICAS-TUMORAIS E LINFÓCITOS HUMANOS: \\ EM BUSCA DE ESTRATÉGIAS DE APRIMORAMENTO DE VACINA \\ ANTITUMORAL
}

Tese apresentada ao Programa de Pós-Graduação em Imunologia do Instituto de Ciências Biomédicas da Universidade de São Paulo, para obtenção do Título de Doutor em Ciências. 
KAREN STEPONAVICIUS PIEDADE CRUZ

INTERAÇÕES CELULARES EM AMBIENTE TRIDIMENSIONAL ENTRE CÉLULAS HÍBRIDAS DENDRÍTICAS-TUMORAIS E LINFÓCITOS HUMANOS:

EM BUSCA DE ESTRATÉGIAS DE APRIMORAMENTO DE VACINA ANTITUMORAL

Tese apresentada ao Programa de Pós-Graduação em Imunologia do Instituto de Ciências Biomédicas da Universidade de São Paulo, para obtenção do Título de Doutor em Ciências.

Área de Concentração: Imunologia

Orientador: Prof. Dr. José Alexandre Marzagão Barbuto

Co-Orientadora: Profa. Dra. Vanessa Morais Freitas

Versão original

São Paulo

2015 


\section{DADOS DE CATALOGAÇÃO NA PUBLICAÇÃO (CIP) \\ Serviço de Biblioteca e Informação Biomédica do Instituto de Ciências Biomédicas da Universidade de São Paulo}

reprodução não autorizada pelo autor

Cruz, Karen Steponavicius Piedade.

Interações celulares em ambiente tridimensional entre células híbridas dendríticas-tumorais e linfócitos humanos: em busca de estratégias de aprimoramento de vacina antitumoral / Karen Steponavicius Piedade Cruz. -- São Paulo, 2015.

Orientador: Prof. Dr. Jose Alexandre Marzagão Barbuto.

Tese (Doutorado) - Universidade de São Paulo. Instituto de Ciências Biomédicas. Departamento de Imunologia. Área de concentração: Imunologia. Linha de pesquisa: Citofisiologia do trofoblasto.

Versão do título para o inglês: Cell interactions in three-dimensional environment between dendritic cell-tumor hybrid cells and human lymphocytes: looking for antitumor vaccine enhancement strategies.

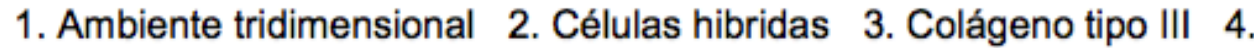
Células dendríticas 5. Linfócitos T I. Barbuto, Prof. Dr. Jose Alexandre Marzagão II. Universidade de São Paulo. Instituto de Ciências Biomédicas. Programa de Pós-Graduação em Imunologia III. Título. 


\title{
UNIVERSIDADE DE SÃO PAULO INSTITUTO DE CIENCIAS BIOMÉDICAS
}

\begin{abstract}
Candidato(a):
Karen Steponavicius Piedade Cruz.

Título da Tese: $\quad$ Interap̧ōes celulares em ambiente tridimensional entre células hibridas dendríticas-tumorais e linfócitos humanos: em busca de estratégias de aprimoramento de vacina antitumoral.
\end{abstract}

Orientador(a): $\quad$ Prof. Dr. Jose Alexandre Marzagão Barbuto.

A Comissāo Julgadora dos trabalhos de Defesa da Tese de Doutorado, em sessāo pública realizada a . J................., considerou
( ) Aprovado(a)
( ) Reprovado(a)

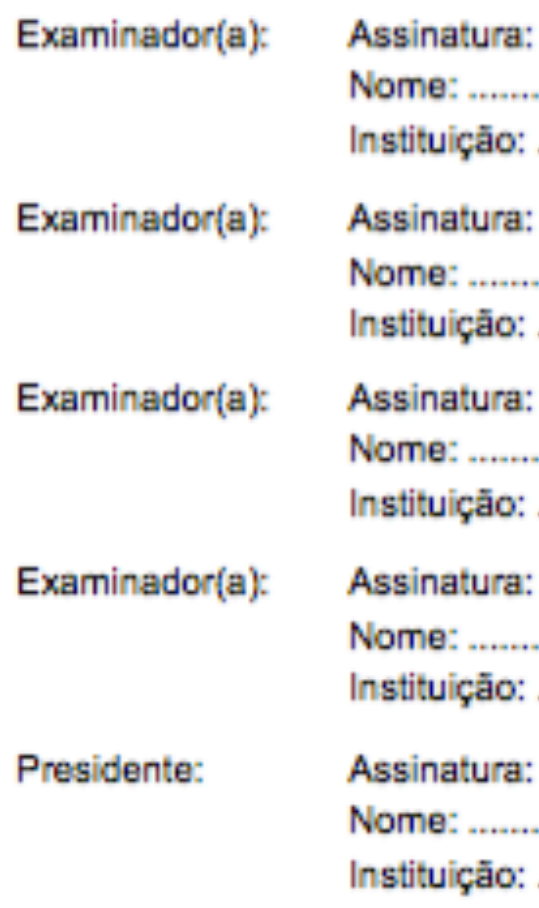


São Paulo, 27 de outubro de 2010.

\section{PARECER 968/CEP}

A Comissão de Ética em Pesquisas com Seres Humanos do ICB, na sessão de 26.10.2010, APROVOU o projeto intitulado: "Interações celulares em ambiente tridimensional entre células híbridas dendríticas-tumorais e linfócitos humanos: em busca de estratégias de aprimoramento de vacina antitumoral" sob responsabilidade de execução dos autores Prof. Dr. José Alexandre M. Barbuto e a aluna Karen Steponavicius Piedade Cruz.

A Comissão sugere para facilidade de estudos futuros a inclusão do item, no Termo de Consentimento Livre Esclarecido:

X) Concordo que o material poderá ser utilizado em outros projetos desde que autorizado pela Comissão de Ética deste Instituto e pelo responsável por esta pesquisa.
( ) $\operatorname{Sim}$
ou
( ) Não

Cabe aos pesquisadores executantes elaborar e apresentar a este Comitê, relatórios anuais (parciais ou final), de acordo com a resolução 196/06 do Conselho Nacional da Saúde, item IX. 2 letra c.

O primeiro relatório deverá ser encaminhado à Secretaria deste CEP em

26.10.2011

Atenciosamente,

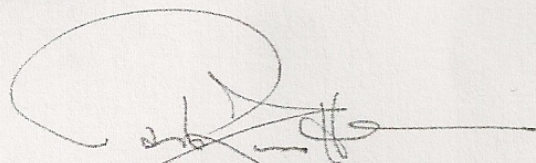

Prof. Dr. PAOLO M. A. ZANOTTO

Coordenador da Comissão de Ética em

Pesquisas com Seres Humanos - ICB/USP 

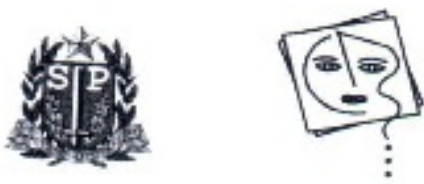

SECRETARIA DE ESTADO DA SAÚDF

Centro de Referência da Saúde da Mulher

\section{Comitê de Ética em Pesquisa}

\section{PARECER CONSUBSTANCIADO DE PROJETO DE PESQUISA}

O Protocolo de Pesquisa: "Interaçōes Celulares em ambiente tridimensional entre células hibridas dendriticas-tumorais e linfócitos humanos : em de Consentimentégias de aprimoramento de vacina anti-tumoral "e o Termo em Pesquisa e considera Esclarecido, foram avaliados por este Comitê de Ética APROVADOS sem restriçōes.

nacionais aprovaçäo, foram seguidas as exigências das Resoluçōes humanos. No presente projeto, relonadas a pesquisas envolvendo seres correspondem ao objetivo for form devidamente enfatizados itens que materiais e metodos: referência Estudo e seu racional; adequaçăo dos do pesquisador na referência bibliográfica pertinente; responsabilidade interrupçāo do estudo nom como possibilidade de Lembramos aos

legislação $251 / 97$ senhores pesquisadores que, no cumprimento da relatórios semestrais Comitê de Ética em Pesquisa (CEP) deverá receber tempo e a criterio do pesquisador ainda, a necessidade delevância. Salientamos que este CEP seja informado quário completo ao final do Estudo. Solicitamos que este CEP seja informado quando da inclusão do primeiro paciente.

Atenciosamente

Dr. Jorge Yoshinori Shida

Coordenador do Comité de Ética

em Pesquisa do CRSM 
À minha família e noivo, os quais foram, são e sempre serão minha prioridade. 


\section{AGRADECIMENTOS}

Aos meus pais, Roseli Steponavicius e José Fernando Piedade Cruz, por todo o amor, assistência, apoio, incentivo, carinho, paciência, puxões de orelha e por todos os seus ensinamentos, sem os quais eu não conseguiria ser metade do que sou hoje;

Ao meu irmão Flavio Steponavicius Piedade Cruz, pelo apoio, carinho, incentivo e por ser meu motivo de orgulho;

A minha avó Marcelina de Jesus Cruz pelo exemplo de força, por todo o carinho, apoio, orações e torcida;

Ao meu noivo Alexandre Urban Borbely, o amor da minha vida, obrigada pelo carinho, amizade e suporte desde o início da faculdade. Você me fez acreditar que daria certo e esteve presente nos momentos de alegria, mas principalmente nos momentos difíceis. Grande parte dessa conquista se deve com certeza ao seu apoio. Obrigada, meu PATETA!

Ao meu orientador Prof. Dr. José Alexandre Marzagão Barbuto, por sua simpatia, incentivo, paciência, por ter me acolhido de braços abertos em seu laboratório desde minha iniciação científica até hoje, pelo seu contagiante espírito de pesquisa e por ter participado de meu processo de formação profissional de maneira positiva;

A minha co-orientadora Profa. Dra. Vanessa Morais Freitas e todos os alunos pela inestimável colaboração neste trabalho. Agradeço pelas sugestões, pelo treinamento e pela paciência para responder minhas eternas dúvidas. Obrigada ainda pela amizade, pelo afeto, e por toda ajuda extra-laboratório que você sempre tem me dado;

A todos os meus amigos do laboratório (atuais e antigos): Ana Carolina, Bruna, Cecília, Cristiano, Lucila, Maria, Mariana, Patrícia Bergami, Roberto e Thiago pela amizade, pelos momentos descontraídos e por toda a ajuda que sempre precisei, em especial por suas contribuições valiosas. Em especial para a Cecília e o Thiago que me ajudaram muito na etapa final da tese.

Aos amigos que já passaram e aos presentes do laboratório de Imunologia de Tumores: Aline, Ariane, Gio, Grá, Isabella, Kleber, Lilian, Patrícia Toniolo, Ricardo, Roberta, Rodrigo, Salomão e Sarah pelos auxílios, trocas de experiências e pela boa companhia dentro e fora do laboratório.

As técnicas Célia Pizzo e Claudinha Cunha do laboratório de Imunologia de Tumores pela ajuda sempre que necessária, pela amizade e risadas.

Ao Prof. Dr. Ruy Gataldoni Jaeger e todos os alunos do Laboratório de Biologia Tumoral pela inestimável ajuda em momentos críticos do trabalho. Obrigada pelas várias formas de auxílio prestadas durante a realização deste trabalho, incluindo consultorias experimentais, cessão de reagentes, e permissão para utilizar seus equipamentos e seu laboratório; 
À minha amiga Adriane Siqueira pela sua inestimável contribuição ao meu Doutorado, mas acima de tudo, pela amizade e companheirismo.

Aos meus sogros, Lúcia e Ladislau e ao meu cunhado Artur, que sempre me acolheram em seu ambiente familiar. Obrigada pelo carinho.

Ao Mário Cruz, funcionário do setor de microscopia confocal do CEFAP-ICB, por sua inestimável ajuda, simpatia e paciência em praticamente todas as semanas em que apareci desesperada por um horário;

Ao pessoal do Banco de Sangue do Hospital Oswaldo Cruz, pela ajuda, simpatia e paciência quando liguei inúmeras vezes;

Ao pessoal do Hospital Pérola Byington pela ajuda, em especial aos enfermeiros Aline e Henrique Guedes por toda ajuda desde a obtenção do prontuário até a a obtenção da amostra no centro cirúrgico.

A Beth e Carlos do CTR - IPEN por toda simpatia, disponibilidade e ajuda na irradiação das células.

Aos doadores de sangue e as pacientes com câncer que aceitaram participar deste estudo, sendo solidários e contribuindo imensamente para o progresso da ciência;

A todos os professores do departamento de Imunologia/ICB-USP pela contribuição na minha formação profissional, bem como disponibilização de laboratórios e reagentes.

Aos demais colegas de departamento pela amizade, discussões imunológicas e momentos de descontração.

Aos funcionários Amanda, Eni, João e Jotelma pela atenção e grande ajuda nos tramites burocráticos.

Aos funcionários do setor Audiovisual Moisés, Márcio e Andréas por sempre estarem dispostos a nos ajudar.

Aos funcionários da portaria pela atenção e cuidado com a nossa segurança.

Aos funcionários da Biblioteca do ICB, que trabalham com dedicação, presteza e eficiência.

A FAPESP e ao CNPq-PIBIC pelo auxílio financeiro nesses anos doutorado direto;

E finalmente, aqueles cujos nomes não foram explicitamente citados, mas que de alguma maneira me influenciaram em decisões, me apoiaram e incentivaram, ficam meus sinceros agradecimentos. 
Alea iacta est - A sorte está lançada.

Gaius Julius Caesa 


\section{RESUMO}

Cruz, K. S. P. Interações celulares em ambiente tridimensional entre células híbridas dendríticas-tumorais e linfócitos humanos: em busca de estratégias de aprimoramento de vacina antitumoral. 2015. $131 \mathrm{f}$. Tese (Doutorado em Imunologia) - Instituto de Ciências Biomédicas, Universidade de São Paulo, São Paulo, 2015.

Células híbridas dendríticas-tumorais vem sendo usadas em vacinas terapêuticas para portadores de neoplasias metastáticas e tem mostrado resultados promissores. Porém, o comportamento $\mathrm{e}$ as funções desempenhadas por essas células híbridas ainda são insuficientemente conhecidos. Neste contexto, o presente trabalho pretende estudar a interação dessas células híbridas com diferentes subpopulações de linfócitos $\mathrm{T}$ em um ambiente tridimensional (3D) com ou sem colágeno tipo III. Para isso, células mononucleares do sangue periférico foram diferenciadas em células dendríticas (DCs) e linfócitos $\mathrm{T}$ foram separados por colunas imunomagnéticas. Inicialmente, DCs em diferentes estágios de maturação e linfócitos $\mathrm{T} \mathrm{CD}^{+}$e linfócitos $\mathrm{T} \mathrm{CD} 8^{+}$foram cocultivados no ambiente $3 \mathrm{D}$ Biotek tratado com colágeno do tipo III ou não e analisados em diversos parâmetros. DCs só interagiram com linfócitos $\mathrm{T} \mathrm{CD}^{+}$quando em presença de colágeno III. Com relação ao tempo e tipo de interação, o tempo de interação de $\mathrm{DCs}$ com linfócitos $\mathrm{T} \mathrm{CD}^{+}$diminui conforme a maturação e DCs maduras apresentaram um tipo de interação onde elas preferencialmente interagem com um único linfócito. Já a interação com linfócitos $\mathrm{T} C D 8^{+}$ não foram observadas diferenças quanto ao tempo de interação e DCs maduras foram capazes de interagir repetidas vezes com o mesmo linfócito. Os ensaios de migração mostraram que a presença colágeno tipo III ou mesmo a presença de DCs em diferentes estágios de maturação podem alterar a velocidade de migração dos linfócitos $\mathrm{T} C \mathrm{CD} 8^{+}$. Além disso, a velocidade de migração dos linfócitos $\mathrm{T} \mathrm{CD}^{+}$diminui após o contato e que há uma relação com o estágio de maturação das DCs. A maturação completa das DCs e a presença de colágeno III induziram a produção de IL-2 mas não foi observado uma aumento na proliferação de linfócitos $\mathrm{T}$ embora exista uma tendência a aumentar. Uma vez determinadas as condições, analisamos todos os parâmetros anteriores com DCs maduras fundidas com células tumorais de pacientes com câncer de mama ou com células da linhagem SKBR-3 cocultivadas com linfócitos T. Nossos resultados indicaram que células no grupo Fusão Tumoral interagiu tanto com linfócitos $\mathrm{T} \mathrm{CD}^{+}$quanto com linfócitos $\mathrm{T} \mathrm{CD}^{+}$mas o grupo Fusão Linhagem interagiram apenas com linfócitos $\mathrm{T} \mathrm{CD}^{+}$. Com relação ao tempo interação os linfócitos $\mathrm{T}$ $\mathrm{CD}^{+}$interagiram 2 vezes mais no grupo Fusão Linhagem do que nos grupos Sem Fusão e Fusão Tumoral e sua interação foi apenas com um único linfócito. Já com linfócitos T $\mathrm{CD} 8^{+} \mathrm{o}$ grupo Fusão Tumoral interagiu mais tempo quando comparado aos outros dois grupos. Células híbridas apresentaram a velocidade de migração reduzida quando comparadas as DCs. Não foi observada IL-2 na culturas onde as células híbridas estavam presentes e a proliferação de linfócitos no grupo Fusão Tumoral também não foi observada. Assim, a cocultura 3D foi capaz de demonstrar que células híbridas derivadas de câncer de mama não possuem comportamento similar ao de outras células, mostrando a importância de um protocolo personalizado para cada tipo de tumor, levando em consideração suas características única.

Palavras-chaves: Ambiente Tridimensional. Células Híbridas. Colágeno tipo III. Células Dendríticas. Linfócitos T. 


\begin{abstract}
Cruz K. S. P. Cell interactions in three-dimensional environment between dendritic celltumor hybrid cells and human lymphocytes: looking for antitumor vaccine enhancement strategies. 2015. 131 f. Ph. D. thesis (Immunology). Instituto de Ciências Biomédicas, Universidade de São Paulo, São Paulo, 2015.
\end{abstract}

Dendritic cell-tumor hybrid cells have been used in therapeutic vaccines for people with metastatic cancer and have shown promising results. However, the behavior and the functions performed by these hybrid cells are still insufficiently known. In this context, this study aims to analyze the interaction of these hybrid cells with different subpopulations of $T$ lymphocytes in a three dimensional environment (3D) with or without collagen type III. Therefore, peripheral blood mononuclear cells were differentiated into dendritic cells (DCs) and the $\mathrm{T}$ lymphocytes were separated by immunomagnetic columns. Initially, DCs at different stages of maturation and $\mathrm{CD} 4^{+} \mathrm{T}$ lymphocytes and $\mathrm{CD} 8^{+} \mathrm{T}$ lymphocytes were cocultured in the Biotek 3D environment and treated or not with collagen type III with further analyzes of several parameters. DCs only interacted with $\mathrm{CD}^{+} \mathrm{T}$ lymphocytes when in the presence of collagen type III. DCs interaction time with $\mathrm{CD} 4^{+} \mathrm{T}$ lymphocytes decreases with maturation and mature DCs showed a type of interaction where they preferentially interact with a single lymphocyte. Moreover, regarding the interaction with $\mathrm{CD} 8^{+}$, no differences were observed concerning the interaction time and mature DCs were able to interact repeatedly with the same lymphocyte. Migration assays showed that the presence of collagen type III or even the presence of DCs in different stages of maturation could alter the migration speed of $\mathrm{CD}^{+} \mathrm{T}$ lymphocytes. Furthermore, the migratory speed of $\mathrm{CD}^{+} \mathrm{T}$ lymphocytes after interaction decreases, and there is a relation to DCs stage of maturation. Full maturation of DCs and the presence of collagen type III induced IL-2 production although T lymphocytes proliferation presented only a tendency to increase. Furthermore, we analyzed all the previous parameters with mature DCs fused with tumor cells from patients with breast cancer or the SKBR-3 cell line co-cultured with T lymphocytes. Our results indicated that cells in Tumor Fusion group interacted with both $\mathrm{CD}^{+}$and $\mathrm{CD} 8^{+} \mathrm{T}$ lymphocytes, however the SKBR-3 Fusion group interacted only with $\mathrm{CD}^{+} \mathrm{T}$ lymphocytes. The $\mathrm{CD} 4^{+} \mathrm{T}$ lymphocytes interacted 2 times more in the SKBR-3 Fusion group than in Control and Tumor Fusion groups. Besides, their interaction was only with a single lymphocyte. $\mathrm{CD} 8^{+} \mathrm{T}$ lymphocytes interaction with the Tumor Fusion group resulted in longer interactions when in comparison with the other two groups and hybrid cells had a reduced migratory speed in comparison with DCs. No IL-2 was observed in cultures where the hybrid cells were present and the proliferation of lymphocytes in Tumor Fusion group was not observed. In conclusion, the 3D co-culture was able to demonstrate that hybrid cells derived from breast cancer had not a similar behavior to the other cells showing the importance of a custom protocol for each tumor type, taking into consideration the unique characteristics.

Keywords: Three-dimensional environment. Hybrid cells. Collagen type III. Dendritic cells. T lymphocytes. 


\section{LISTA DE FIGURAS}

Figura 1 - Método de compensação no programa FlowJo com esferas magnéticas..........36

Figura 2 - Método de análise da pureza de linfócitos e monócitos no programa FlowJo

Figura 3 - Método de análise da fenotipagem de DCs

Figura 4 - Ilustração mostrando a estrutura 3D Biotek ${ }^{\mathrm{TM}}$. 48

Figura 5 - Método de análise da proliferação celular. 51

Figura 6 - Delineamento Experimental dos grupos Sem Col III vs Col III 54

Figura 7 - Delineamento Experimental dos grupos Sem Fusão vs Fusão Linhagem vs Fusão Tumoral 54

Figura 8 - Enriquecimento de monócitos do sangue periférico após seleção negativa por esferas imunomagnéticas

Figura 9 - Enriquecimento de linfócitos $\mathrm{T} \mathrm{CD3}^{+}$do sangue periférico após seleção negativa por esferas imunomagnéticas 58

Figura 10 - Enriquecimento de linfócitos $\mathrm{T} \mathrm{CD4}^{+}$do sangue periférico após seleção positiva por esferas imunomagnéticas .

Figura 11 - Enriquecimento de linfócitos $\mathrm{T} \mathrm{CD8}^{+}$do sangue periférico após seleção negativa por esferas imunomagnéticas ....................................................................59

Figura 12 - Fotomicrografias de culturas para diferenciação em DCs. ...........................61

Figura 13 - Expressão de CD11c ${ }^{+}$e HLA-DR ${ }^{+}$em monócitos ...............................................62

Figura 14 - Expressão de CD11c ${ }^{+} \mathrm{HLA}^{-D R^{+}}$em 0h-DCs, 2h-mDCs e 48h-mDCs ............ 63

Figura 15 - Expressão de CD14 ${ }^{+}$em monócitos, 0h-DCs, 2h-mDCs e 48h-mDCs............64

Figura 16 - Expressão de CD40 ${ }^{+}$em monócitos, 0h-DCs, 2h-mDCs e 48h-mDCs............ 65

Figura 17 - Expressão de $\mathrm{CD80}^{+}$em monócitos, 0h-DCs, 2h-mDCs e 48h-mDCs ...........66

Figura 18 - Expressão de CD86 $^{+}$em monócitos, 0h-DCs, 2h-mDCs e 48h-mDCs............. 67

Figura 19 - Expressão de $\mathrm{CD83}^{+}$em monócitos, 0h-DCs, 2h-mDCs e 48h-mDCs............68

Figura 20 - Expressão de CD1a ${ }^{+}$em monócitos, 0h-DCs, 2h-mDCs e 48h-mDCs............69

Figura 21 - Expressão de CD209 ${ }^{+}$em monócitos, 0h-DCs, 2h-mDCs e 48h-mDCs.......... 70

Figura 22 - Expressão de CCR7 $7^{+}$em monócitos, 0h-DCs, 2h-mDCs e 48h-mDCs. .......... 71

Figura 23 - Expressão de PD-L1 ${ }^{+}$em monócitos, 0h-DCs, 2h-mDCs e 48h-mDCs ..........72

Figura 24 - Fotomicrografias de linfonodo corado com a coloração de picro-sírius observados em luz não-polarizada. ..................................................................................75

Figura 25 - Fotomicrografias de linfonodo marcado com colágenos do tipo III e I ......... 76 


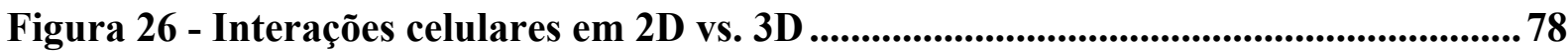

Figura 27 - Esquema mostrando as dimensões espaciais dos eixos $\mathrm{X}, \mathrm{Y}$ e $\mathrm{Z}$................... 79

Figura 28 - Interação celular que foi considerada .......................................................................80

Figura 29 - Interação celular que foi desconsiderada ...........................................................80

Figura 30 - Porcentagem das interações celulares em ambiente 3D ................................81

Figura 31 - Tempo de interação celular no ambiente 3D na presença ou ausência de colágeno tipo III entre linfócitos $\mathrm{T} \mathrm{CD3}^{+} \mathrm{CD4}^{+}$e linfócitos $\mathrm{T} \mathrm{CD3}^{+} \mathrm{CD8}^{+}$e $\mathrm{DCs}$ em

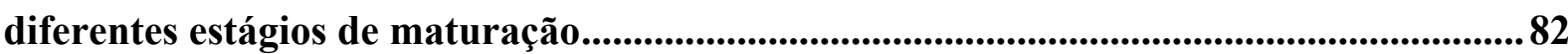

Figura 32 - Migração de DCs sem contato com nenhum linfócito $\mathrm{T}$ em um ambiente 3D tratado com colágeno tipo III ou não

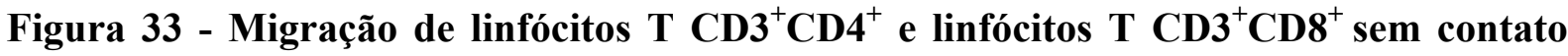
com DCs no ambiente 3D tratado com colágeno do tipo III ou não

Figura 34 - Migração de DCs pré e pós interação com linfócitos $\mathrm{T} \mathrm{CD3}^{+} \mathrm{CD4}^{+}$e linfócitos $\mathrm{T} \mathrm{CD3}^{+} \mathrm{CD8}^{+} \mathrm{em}$ um ambiente 3D tratado com colágeno tipo III ou não 86

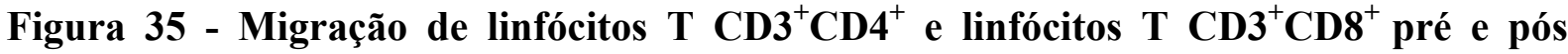
interação com DCs em um ambiente 3D tratado com colágeno tipo III ou não 87

Figura 36 - Avaliação das citocinas peresentes no sobrenadante após 17 horas de cocultivo nos grupos Sem Col III e Col III. 88

Figura 37 - Representação gráfica do resultado da diluição do CTV 89

Figura 38 - Caracterização das células híbridas dendríticas-tumorais .90

Figura 39 - Porcentagem das interações celulares em ambiente 3D 91

Figura 40 - Tempo de interação celular no ambiente 3D Biotek nos grupos Sem Fusão, Fusão Linhagem e Fusão Tumoral. 92

Figura 41 - Migração de DCs ou células fundidas sem contato com nenhum linfócito $T$ nos grupos Sem Fusão, Fusão Linhagem e Fusão Tumoral

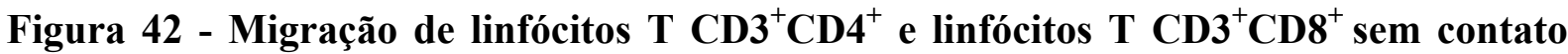
com DCs nos grupos Sem Fusão, Fusão Linhagem e Fusão Tumoral

Figura 43 - Migração de DCs ou células fundidas pré e pós interação com linfócitos T $\mathrm{CD3}^{+} \mathrm{CD4}^{+}$e linfócitos $\mathrm{T} \mathrm{CD3}^{+} \mathrm{CD8}^{+}$nos grupos Sem Fusão, Fusão Linhagem e Fusão Tumoral

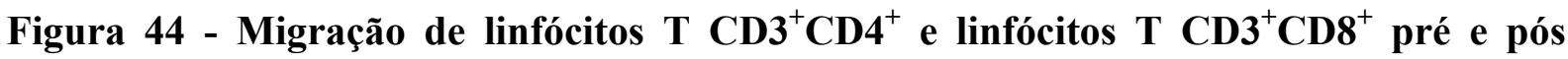
interação com as DCs ou células fundidas nos grupos Sem Fusão, Fusão Linhagem e Fusão Tumoral. 96

Figura 45 - Avaliação das citocinas peresentes no sobrenadante após 17 horas de cocultivo nos grupos Sem Fusão, Fusão Linhagem e Fusão Tumoral ................................97

Figura 46 - Representação gráfica do resultado da diluição do CTV ..................................98 


\section{LISTA DE TABELAS}

Tabela 1 - Pacientes incluídas no estudo 32

Tabela 2 - Anticorpos monoclonais utilizados para avaliação da pureza de monócitos, linfócitos $\mathrm{T} \mathrm{CD3}^{+}$, linfócitos $\mathrm{T} \mathrm{CD3}^{+} \mathrm{CD4}^{+}$e linfócitos $\mathrm{T} \mathrm{CD3}^{+} \mathrm{CD8}^{+}$ 37

Tabela 3 - Anticorpos monoclonais utilizados para avaliação do fenótipo de membrana dos monócitos e das DCs (dos grupos 0h-DCs, 2h-mDCs e 48h-mDCs) 38

Tabela 4 - Anticorpos monoclonais utilizados em testes de interações celulares. 43

Tabela 5 - Anticorpos monoclonais utilizados para marcação das células tumorais, SKBR-3 e das DCs 45

Tabela 6 - Anticorpos monoclonais (BD Biosciences) utilizados para avaliação das subpopulações de linfócitos $\mathrm{T}$

Tabela 7 - Porcentagem dos diferentes tipos de interações celulares entre os grupos 0hDCs, 2h-mDCs e 48h-mDCs e linfócitos $\mathrm{T} \mathrm{CD3}^{+} \mathrm{CD}^{+}$no grupo Sem Col III e no grupo Col III . .83

Tabela 8 - Porcentagem dos diferentes tipos de interações celulares entre os grupos 0hDCs, 2h-mDCs e 48h-mDCs e linfócitos $\mathrm{T} \mathrm{CD3}^{+} \mathrm{CD8}^{+}$no grupo Sem Col III e no grupo Col III .83

Tabela 9 - Porcentagem dos diferentes tipos de interações celulares dos linfócitos $T$ $\mathrm{CD3}^{+} \mathrm{CD4}^{+}$e linfócitos $\mathrm{T} \mathrm{CD3}^{+} \mathrm{CD8}^{+}$nos grupos Sem Fusão, Fusão Linhagem e Fusão Tumoral 93 
2D Amibiente Bidimendional

3D Ambiente Tridimensional

ANOVA Análise de Variância

APC Aloficocianina

APCs Células Apresentadoras de Antígenos

BSA Albumina Sérica Bovina

CBA Ensaio de citometria por beads

CCR Receptor de quimiocinas

CD Cluster of Differentiation

CFSE Carboxifluoresceína succinimidil éster

CTLs Linfócitos T Citotóxicos

CTV CellTrace Violet

DAP-I 4',6-diamino-2-fenilindol

DCs Células Dendríticas

DMSO Dimetilsulfóxido

EDTA Ácido Etilenodiamino Tetra-Acético

FITC Fluoresceína isotiocianato

FSC forward scatter

GM-CSF Estimulador de Colônia de Macrófagos e Granulócitos

HLA Antígeno Leucocitário Humano

HSPs Proteínas de Choque Térmico

IL Interleucina

MEC Matriz Extracelular

MFI Intensidade Mediana de Fluorescência

MHC Complexo Principal de Histocompatibilidade

PBMCs Células Mononucleares do Sangue Periférico

PBS Salina Tamponada com Fosfato

PE Ficoeritrina

PerCP Clorofila Peridinina

SFB Soro Fetal Bovino

SSC side scatter 
TCR Receptor de Células T

TNF- $\alpha \quad$ Fator de Necrose Tumoral $\alpha$ 


\section{SUMÁRIO}

1 INTRODUÇÃO E JUSTIFICATIVA...............................................................................19

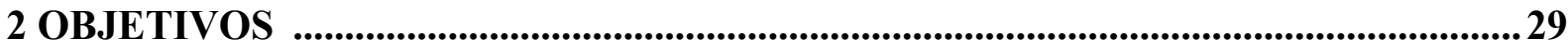

3 MATERIAIS e MÉTODOS .................................................................................31

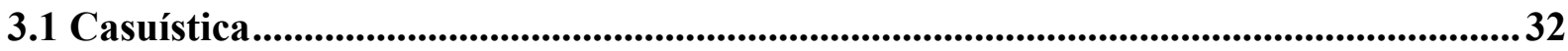

3.2 Diferenciação de células dendríticas in vitro a partir de monócitos derivados de sangue periférico ..........................................................................................................................33

3.3 Separação imunomagnética de linfócitos $\mathrm{T} \mathrm{CD3}^{+}$.........................................................33

3.4 Separação imunomagnética de linfócitos $\mathrm{T} \mathrm{CD3}^{+} \mathrm{CD}^{+}$e linfócitos $\mathrm{T} \mathrm{CD3}^{+} \mathrm{CD8}^{+} \ldots . . .34$

3.5 Avaliação por citometria de fluxo da pureza das populações de monócitos e linfócitos 34

3.6 Avaliação do fenótipo de membrana de monócitos e das DCs por citometria de

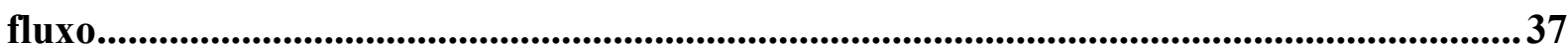

3.7 Obtenção dos Animais .....................................................................................................41

3.7.1 Coloração por Picro-Sírius para a identificação de Fibras Colágenas...........................41

3.7.2 Imunofluorescência ..................................................................................................................41

3.8 Testes com diferentes tipos de matrizes 3D........................................................................42

3.9 Interações celulares entre DCs e linfócitos $T$ em ambiente 3D .........................................43

3.9.1 Marcação de linfócitos T com Carboxifluoresceína succinimidil éster (CFSE)...............43

3.9.2 Marcação de linfócitos T com CellTracker Orange............................................................43

3.9.3 Marcação de DCs com CellTracker Red..............................................................................44

3.10 Fusão Celular .....................................................................................................................44

3.10.1 Digestão e isolamento de células neoplásicas de adenocarcinoma ductal invasivo de mama ........................................................................................................................................44

3.10.2 Cocultivo da linhgem SKBR-3 .........................................................................................45

3.10.3 Marcação de receptores de membrana das células tumorais, SKBR-3 e DCs .............45

3.10.4 Geração de células hibridas dendríticas-tumorais ...........................................................46

3.11 Cocultivo de DCs ou células híbridas e linfócitos T em ambiente 3D.........................46

3.12 Análise da duração das interações celulares e migração de DCs, células híbridas e linfócitos $\mathrm{T}$ em ambiente 3D .................................................................................................48

3.13 Detecção de citocinas por ensaio de citometria por beads (CBA) ..................................49 
3.14 Ensaio da proliferação de linfócitos $T$ cocultivados com células dendríticas ou células híbridas dendríticas-tumorais..........................................................................49

3.14.1 Marcação de linfócitos com CellTrace Violet (CTV), anti-CD4, anti-CD8 e anti-CD25 e análise por Citometria de Fluxo ...................................................................................................49

3.14.2 Avaliação da proliferação celular ....................................................................50

3.15 Delineamento experimental dos cocultivos em ambiente 3D ...................................52

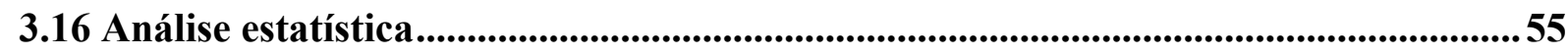

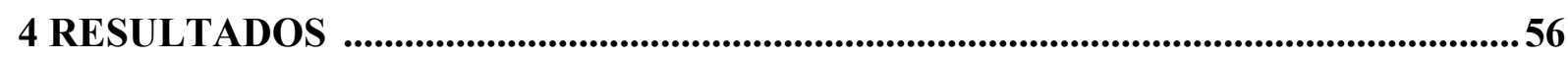

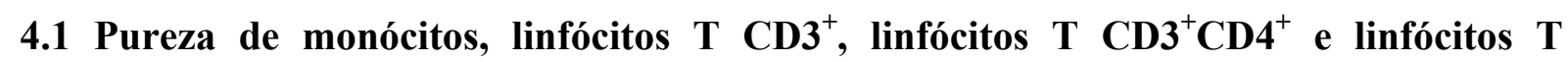

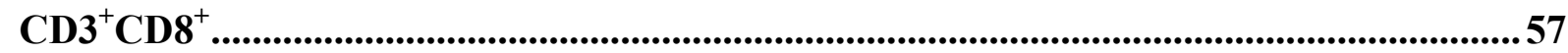

4.2 Características morfológicas de monócitos, 0h-DCs, $2 \mathrm{~h}$-mDCs e 48h-mDCs .............60

4.3 Caracterização imunofenotípica de monócitos, 0h-DCs, 2h-mDCs e 48h-mDCs ....... 62

4.4 Análise dos testes para a escolha do tipo de matriz 3D .................................................73

4.5 Caracterização da rede colágena em linfonodo murino....................................................74

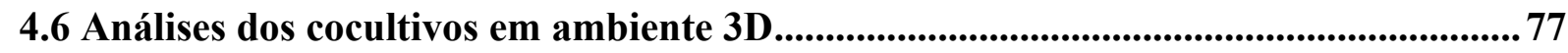

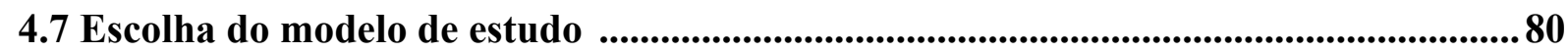

4.8 Análises das interações celulares entre DCs e Linfócitos $T$ nas coculturas em

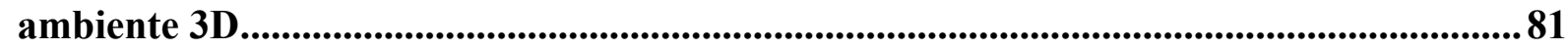

4.8.1 Análises funcionais entre DCs e linfócitos T nas coculturas em ambiente $3 D$................88

4.9 Caracterização das células híbridas............................................................................89

4.10 Análise das interações entre células híbridas e linfócitos $T$ nas coculturas em ambiente 3D....................................................................................................................1

4.10.1 Análises funcionais entre células híbridas e linfócitos $T$ nas coculturas em ambiente

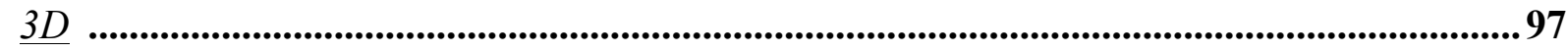

5 DISCUSSÃO

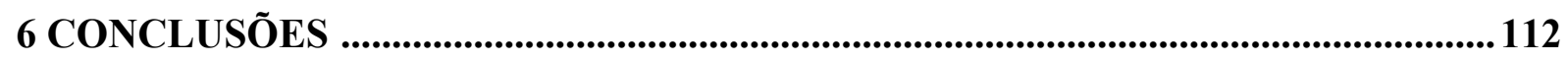

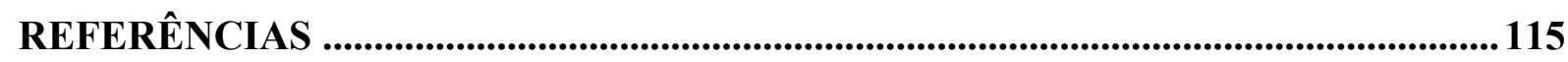




\section{INTRODUÇÃO E JUSTIFICATIVA}

O sistema imunológico é um sistema complexo de reconhecimento, composto por diversas células e moléculas que interagem entre si e com outros sistemas do organismo para a manutenção da homeostase. Entre todas as células existentes neste complexo sistema há um tipo celular que desempenha um papel fundamental na organização e modulação da resposta imunológica: as células dendríticas (DCs) (BANCHEREAU; STEINMAN, 1998; BANCHEREAU et al., 2000). Essas células foram identificadas em órgãos linfóides de camundongos e foram caracterizadas de acordo com sua morfologia específica, contendo um grande número de mitocôndrias, endossomos de várias densidades, núcleo irregular e a presença de extensões citoplasmáticas arranjadas na forma de dendritos (STEINMAN; COHN, 1973). Além disso, essas células estão amplamente distribuídas em todo o organismo no qual localizam-se principalmente na pele, nas mucosas e nos órgãos linfóides (BANCHEREAU et al., 2000; SATO; FUJITA, 2007; SERTL et al., 1986; STEINMAN; COHN, 1973; VAN VOORHIS et al., 1982).

Dados da literatura sobre as células dendríticas sugerem que essas células constituem uma heterogênea população que se divide em diferentes subpopulações (ARDAVIN et al., 2001; BANCHEREAU et al., 2000; COLLIN; MCGOVERN; HANIFFA, 2013; NAIK, 2008; TAN; O’NEILL, 2005). Embora a classificação dessas células em subpopulações sofra variações entre os diversos autores, há um consenso de que as DCs possam ser divididas em dois segmentos principais: o das DCs mielóides e o das DCs plasmocitóides (BANCHEREAU et al., 2000; COLLIN; MCGOVERN; HANIFFA, 2013; ZIEGLERHEITBROCK et al., 2010). As DCs plasmocitóides se caracterizam por possuírem uma capacidade de ativação de linfócitos T muito baixa (REIZIS et al., 2011), pela ausência de CD11c e presença de CD123 em sua superfície (COLONNA; TRINCHIERI; LIU, 2005; REIZIS et al., 2011) além de produzirem grandes quantidades de interferon (REIZIS et al., 2011). Já as DCs mielóides tem sido reconhecidas pela expressão de CD11c (O’DOHERTY et al., 1994) e por sua alta capacidade de apresentação de antígenos aos linfócitos $\mathrm{T}$ (BANCHEREAU et al., 2000; STEINMAN, 1991). Além disso, Schuler e Steinman (1985) foram os primeiros a descrever que as DCs mielóides apresentavam dois estágios de maturação, denominando-as de DCs imaturas e maduras.

Células dendríticas imaturas residentes em tecidos não-linfóides e em um estado de homeostasia estão principalmente envolvidas na captura e no processamento dos antígenos (BANCHEREAU et al., 2000; GUERMONPREZ et al., 2002). Outra característica importante 
deste tipo celular é a expressão de receptores de quimiocinas, como CCR1, CCR2 e CCR5 (SALLUSTO et al., 1998). Quando no tecido de origem ocorrem perturbações na homeostasia, as quais são detectadas por receptores para padrões moleculares amplamente expressos pelas DCs, se inicia o processo de maturação dessas células (BANCHEREAU et al., 2000; DZOPALIC et al., 2012; GUERMONPREZ et al., 2002). Neste processo, as células apresentam redução de sua capacidade endocítica, aumentam a produção de citocinas inflamatórias e passam a expressar, entre outras moléculas, o CCR7 (BANCHEREAU et al., 2000; GUERMONPREZ et al., 2002; SAEKI et al., 1999; SALLUSTO et al., 1998; YANAGIHARA et al., 1998). Do mesmo modo, as DCs maduras expressam outras características interessantes: a) aumentam a densidade de moléculas de classe II codificadas pelo complexo principal de histocompatibilidade (MHC) na membrana citoplasmática; b) expressam altos níveis de moléculas coestimuladoras de linfócitos T (CD40, CD80 e CD86) e c) passam a expressar um indicador da maturação, o CD83 (BANCHEREAU et al., 2000; ZHOU; TEDDER, 1996). A mudança de expressão dos receptores de quimiocinas de CCR1, CCR2 e CCR5 para CCR7 favorece a migração das DCs ativadas (e dos linfócitos T “naïve”) para a região paracortical dos linfonodos (CYSTER, 2005; SALLUSTO et al., 1998). As DCs maduras também possuem a capacidade de realizar a apresentação cruzada de antígenos endocitados no contexto de moléculas de classe I do MHC (CARBONE et al., 1998). Devido a essas e outras características, após sua maturação fenotípica e funcional, as DCs tornam-se competentes na ativação de linfócitos $\mathrm{T}$ "nä̈ve", sendo consideradas as principais células apresentadoras de antígenos (APCs) (BANCHEREAU, STEINMAN, 1998; BANCHEREAU et al., 2000; GUERMONPREZ et al., 2002). Dessa forma, tanto linfócitos T auxiliares (CD4 ${ }^{+}$) como citotóxicos $\left(\mathrm{CD}^{+}\right)$podem ser ativados por esse tipo de DCs. Além disso, as DCs podem ser caracterizadas por outras moléculas, como a ausência de CD14, um conhecido marcador de monócitos (KIERTSCHER; ROTH, 1996; SALLUSTO, LANZAVECCHIA, 1994); a presença de CD1a, molécula apresentadora de lipídeos e glicolipídeos (AQUINO et al., 2011) e PD-L1, que está associada com um perfil tolerogênico (WÖLFLE et al., 2011). Outra molécula que está presente em DCs é o CD209, que se liga com alta afinidade ás moléculas de adesão intercelular 3, presentes nos linfócitos, e internaliza antígenos que poderão ser apresentados aos linfócitos T (ENGERING et al., 2002).

Para que a apresentação de antígenos para os linfócitos ocorra, o comportamento e a localização desses dois tipos de células nos órgãos linfóides secundários é essencial. Dentre os vários órgãos linfóides, destacam-se os linfonodos, por se interporem à drenagem linfática de todo o organismo. Estes órgãos são tradicionalmente divididos em três regiões: cortical, 
paracortical e medular. A região cortical está localizada perifericamente e apresenta folículos linfóides compostos por agregados de linfócitos B. Dentro de cada uma dessas estruturas é possível identificar um centro germinativo, que corresponde à área onde ocorre a multiplicação mais intensa e a ativação de linfócitos B (KALDJIAN et al., 2001; WILLARDMACK, 2006). No folículo também encontramos um tipo celular especializado, a célula dendrítica folicular, que, embora tenha nome semelhante às DCs, tem origem e funções muito diversas (REZK et al., 2013). A região paracortical, situada na interface das regiões cortical e medular, apresenta predomínio de linfócitos $\mathrm{T} \mathrm{CD}^{+}$além de linfócitos $\mathrm{T} \mathrm{CD}^{+}, \mathrm{DCs}$, macrófagos e as células reticulares. As células reticulares são responsáveis pela síntese e secreção de moléculas de matriz extracelular, que se organizam em fibras reticulares. As fibras colágenas reticulares são muito delgadas e constituídas predominantemente pelo colágeno do tipo III, além de colágeno do tipo I, ambos associados a um elevado teor de proteoglicanos, glicoproteínas e componentes da lamina basal (CASTAÑOS-VELEZ; BIBERFELD; PATARROYO, 1995; KARTTUNEN et al., 1989; KRAMER; ROSEN; MECDONALD, 1988; SOBOCINSKI et al., 2010; WILLARD-MACK, 2006). É nesta região que ocorre a apresentação de antígenos pelas DCs para os linfócitos T (CYSTER, 2005; INGULLI et al., 1997; TAKAHASHI et al., 2001). Por último, a região medular é composta de cordões e seios medulares, sendo rica em macrófagos e plasmócitos (WILLARD-MACK, 2006).

Considerando o papel das DCs na ativação da resposta imune e que seu estágio de maturação funcional influencia significativamente o padrão de resposta imune (BANCHEREAU et al., 2000; PULENDRAN, 2004), essas células tem sido bastante exploradas como instrumentos de imunomodulação (BARBUTO, 2013; GANGULY et al., 2013; VASSALLI, 2013). Dentre estas abordagens, estratégias de vacinação terapêutica contra o câncer tem sido amplamente estudadas (BARBUTO et al., 2004; BARBUTO, 2013; VIK-MO et al., 2013; WANG et al., 2009). A maioria dos protocolos de imunização contra o câncer baseada em DCs não usa o isolamento direto destas células a partir dos tecidos, mas explora a possibilidade da diferenciação in vitro de precursores sanguíneos e da medula óssea em DCs funcionais (BARBUTO et al., 2004; CAUX et al., 1996; ORSINI et al., 2013; RAMOS et al., 2012; SALLUSTO, LANZAVECCHIA, 1994; VIK-MO et al., 2013). Neste contexto, existem diferentes estratégias de geração de vacinas antitumorais: as DCs podem ser incubadas com peptídeos sintéticos (MAYORDOMO et al., 1995; NIU et al., 2012; ROSALIA et al., 2013); com lisados tumorais (CHIANG et al., 2013; KIM et al., 2006; REYES et al., 2013); com proteínas de choque térmico (HSPs) isoladas de células tumorais 
(CASEY et al., 2003; KUROTAKI et al., 2007; PRZEPIORKA; SRIVASTAVA, 1998); ou transfectadas/eletroporadas com RNA tumoral (VAN NUFFEL et al., 2010; VIK-MO et al., 2013; ZHANG et al., 2006). Outra abordagem que vem sendo estudada é o direcionamento de antígenos às DCs, por estratégias diferentes como, por exemplo, o acoplamento do antígeno a anticorpos direcionados contra moléculas características das DCs (BONIFAZ et al., 2004) ou o uso de peptídeos acoplados a receptores do tipo Toll (BALEEIRO et al., 2010).

Outras abordagens ainda procuram modificar as próprias DCs, seja pela transdução com genes para citocinas (KOYA et al., 2004; OJIMA et al., 2006) ou com genes que codificam moléculas co-estimuladoras (WIETHE et al., 2003). Ainda considerando a apresentação de antígenos, mas buscando outra estratégia, para o conseguir, há estudos procurando investigar se exossomos, nanovesículas originadas de compartimentos endossomais (JOHNSTONE et al., 1987), derivados das células tumorais (LI et al., 2013) ou de DCs (CHAPUT et al., 2004; ROMAGNOLI, 2012; VIAUD et al., 2009) podem ser usados como instrumentos para a imunoterapia.

Vale ressaltar que muitas das informações que temos sobre os tumores e a resposta antitumoral se deve, sem dúvida, a utilização de células tumorais primárias (BARBUTO et al., 2004; VIK-MO et al., 2013), mas também devido ao uso de linhagens tumorais (ROSENBLATT et al., 2013; ZHANG et al., 2014; ZHENG; SHU, 2011). O uso de linhagens tumorais possui diversas vantagens, como o seu crescimento rápido e contínuo, proliferação quase ilimitada, homogeneidade fenotípica e a possibilidade de realizar um elevado número de testes em um reduzido intervalo de tempo, permitindo assim maior reprodutividade dos resultados e uma redução dos ensaios com animais (COIMBRA, 2008). A partir de tais estudos, diversos grupos vem utilizando a imunização de portadores de neoplasias com células dendríticas fundidas com células tumorais para a indução da resposta imune contra o tumor (BARBUTO et al., 2004; ROSENBLATT et al., 2013; ZHANG et al., 2014; ZHENG, SHU, 2011). Na estratégia usada em nosso laboratório, as células híbridas dendríticastumorais são obtidas através da fusão de células tumorais do paciente com DCs alogenêicas, obtidas de doadores saudáveis. Essa estratégia contorna um obstáculo potencial: o fato de que a diferenciação de DCs a partir de células precursoras de pacientes portadores de câncer não é tão eficiente quanto a diferenciação de células obtidas de doadores saudáveis (AZEVEDO; LAGINHA; BARBUTO, 2007; EISENDLE et al., 2005; NEVES et al., 2005; ORSINI et al., 2013, RAMOS et al., 2012). Com a fusão, espera-se que as células fundidas passem a apresentar antígenos tumorais no contexto de moléculas codificadas pelo MHC, tanto autólogas (do tumor), quanto alogenêicas (das próprias DCs), acrescentando um efeito 
alogenêico ao estímulo tumor-específico. Esta abordagem trouxe benefício clínico a pacientes com carcinoma renal ou melanoma metastáticos vacinados, com estabilização da doença por períodos superiores a seis meses (BARBUTO et al., 2004). Além do mais, estes pacientes apresentaram recuperação da função das DCs, avaliada pela expressão das moléculas CD80, CD83 e CD86, além da aquisição da capacidade de indução da secreção de interferon- $\gamma$ em culturas mistas linfocitárias (NEVES et al., 2005). Com esses resultados promissores, nosso laboratório vem tentando estabelecer um novo protocolo para pacientes com câncer de mama. O câncer de mama é segundo tipo mais frequente no mundo, e é o mais comum entre as mulheres, respondendo por $22 \%$ dos casos novos a cada ano (INSTITUTO NACIONAL DO CÂNCER, 2014).

Embora animadores, nossos resultados ainda estão longe de atingirem todo o potencial que se poderia se esperar da estratégia. Parte disto se deve, sem dúvida, à heterogeneidade dos tumores tratados e do estado imunológico dos pacientes. Todavia, também há muito que se estabelecer quanto à função imunoestimuladora das células híbridas usadas. Além dos métodos usuais pelos quais se podem estudar as diferentes funções destas células, uma abordagem relativamente recente pode acrescentar ainda mais à caracterização funcional das mesmas: o cultivo em ambiente tridimensional (3D).

Nossa compreensão atual de muitos processos biológicos é amplamente baseada em estudos de populações de células cultivadas em ambientes bidimendionais (2D) e em modelos animais. Porém, essas culturas 2D acabam forçando as células a se ajustarem a uma superfície linear artificial, plana e rígida, assim interferindo diretamente sobre a morfologia celular, a polaridade, o metabolismo e a motilidade, não captando fielmente o comportamento fisiológico das células in vivo (BAKER; CHEN, 2012; LEE; CUDDIHY; KOTOV, 2008). Já os modelos animais são importante fonte de informações mas são limitados para estudos com seres humanos devido ao alto grau de diversidade de mecanismos funcionais e moleculares entre as espécies (RANGARAJAN et al., 2004; TEKLEMBURG; MACKLON, 2009). Portanto, modelos 3D in vitro proporcionam uma terceira abordagem que faz a ponte entre a cultura de células e modelos animais tradicionais (FEDER-MENGUS et al., 2008; GRIFFITH; SWARTZ, 2006; YAMADA; CUKIERMAN, 2007).

O primeiro estudo relatado de uma cultura 3D foi realizado por Carrel em 1912 em que cultivava cardiomiócitos e percebeu que a região mais central de suas colônias apresentava elevado índice de necrose. Como solução a este obstáculo, os cardiomiócitos passaram a ser cultivados sobre uma superfície constituída por fios de seda permitindo uma maior interação 
das células com o ambiente. Desde então, o número de trabalhos utilizando essa nova metodologia cresce em grandes proporções.

As culturas 3D vem sendo utilizadas em diversos trabalhos, como em modelos para estudo de células tumorais (FREITAS; JAEGER, 2002; FREITAS et al., 2008; LEE et al., 1985; SHAW; WROBEL; BRUGGE, 2004; XU et al., 2010), na análise de respostas terapêuticas a medicamentos (DORJ et al., 2013; YIP; CHO, 2013), em doenças autoimunes (SOLOMON et al., 2004), na diferenciação de células-tronco (HOLMES et al., 2013; NAITO et al., 2011), entre outros. Assim, existem diversos tipos de cultura 3D que representam a mais complexa estrutura tridimensional in vivo e restauram características histomorfológicas e funcionais do tecido original. Graças a essa nova abordagem in vitro muito se tem aprendido sobre o comportamento de células imunológicas e células tumorais (COUGOULE et al., 2012; DEBNATH; BRUGGE, 2005; FREITAS; JAEGER, 2002; FREITAS et al., 2008; LEE et al., 1985; REICHARDT; GUNZER; GUNZER, 2007; SHAW; WROBEL; BRUGGE, 2004; XU et al., 2010). Por exemplo, em estudo realizado por Lee et al. (1985) descreve que em culturas 3D de colágeno, as células mamárias passam a secretar beta-caseína, a proteína do leite.

Em estudo realizado por Gunzer et al. (2000a) usando um modelo 3D de matriz de colágeno do tipo I, DCs imaturas murinas foram caracterizadas pela baixa migração, enquanto DCs maduras murinas apresentaram uma alta atividade migratória. Em outro estudo realizado pelo mesmo grupo e utilizando o mesmo modelo 3D, DCs interagiram com linfócitos $\mathrm{T}$ e mantiveram essa interação de forma contínua ao longo de sua superfície por curtos períodos. Esses encontros repetidos levaram a um influxo de cálcio nos linfócitos T e a ativação celular medida pelo aumento dos marcadores de ativação e pela proliferação (GUNZER et al., 2000b). Foi observado também que linfócitos T humanos são capazes de migrar em ambiente 3D revestido de colágeno do tipo I, mas não em Matrigel (COUGOULE et al., 2012). Entretanto, Hachehouche, Chetoui e Aoudjit (2010) mostraram que linfócitos T humanos possuem uma capacidade de migrar através de uma matriz 3D revestida de Matrigel e que, quando ativada por anti-CD3, sua capacidade migratória foi 3 vezes maior. Considerando a organização do sistema imunológico, é evidente que o movimento de suas células é um requisito indispensável para a sua função. As interações celulares, ocorrendo tanto no local de efetuação da resposta, quanto nos órgão linfoides, permitem que informações capturadas num local do organismo influenciem a função de células em outro compartimento, direcionando a resposta para o restabelecimento da homeostasia e da capacidade das células de migrarem de maneira direcionada no organismo. Além disso, células do sistema imunológico que 
interagem transientemente entre si para a troca de sinais específicos, podem apresentar alteração desses sinais se a polaridade celular e a tridimensionalidade forem diferentes in vivo (GUNZER et al., 2000b; PAGE; FLOOD; REYNAUD, 2013; REICHARDT; GUNZER; GUNZER, 2007; SCHMEICHEL; BISSELL, 2003).

Tasaki et al. (2004) utilizaram um sistema 3D que consistia na presença de DCs derivadas de monócitos humanos embebidas em um gel de colágeno do tipo I na camada inferior e, na camada superior, outro gel de colágeno do tipo I contendo células tumorais necróticas e/ou linfócitos T. Eles mostraram a migração de DCs em direção às células tumorais e linfócitos $\mathrm{T}$ e apresentação de antígenos tumorais para os linfócitos T pelas DCs. Além disso, exemplos do potencial desta estratégia também podem ser encontrados na análise das interações entre linfócitos T citotóxicos e células tumorais. Alguns estudos que abordaram este tópico encontraram um fenômeno intrigante: linfócitos $\mathrm{T}$ citotóxicos (CTLs) tumorespecíficos, capazes de reconhecer células tumorais em culturas convencionais, falharam em culturas 3D (DANGLES-MARIE et al., 2003; FEDER-MENGUS et al., 2007; FISCHER et al., 2007; GHOSH et al., 2005; SANTINI et al., 2004). As explicações para esta observação ainda não são bem conhecidas, mas existem dados sugestivos de que em um ambiente $3 \mathrm{D}$, existe uma menor possibilidade de interação das células tumorais com as CTLs, possivelmente por alterações conformacionais (FEDER-MENGUS et al., 2007). Essas mudanças conformacionais em células tumorais modulam também os perfis de expressão gênica, diminuindo a susceptibilidade ao ataque das CTLs (GHOSH et al., 2005). Outra possibilidade sugerida é a produção de ácido lático, que, produzido em alta quantidade por células tumorais cultivadas em esferoides, tem capacidade de suprimir a proliferação e a de produção de citocinas por CTLs humanas (FISCHER et al., 2007). Outros trabalhos encontrando resultados similares, argumentam que o fenômeno poderia ser decorrente de uma deficiência no reconhecimento das células tumorais pelas CTLs causada pela diminuição da expressão de HSPs (DANGLES-MARIE et al., 2003) ou da modificação do metabolismo lipídico (SANTINI et al., 2004) nas células tumorais cultivadas nestes ambientes.

Outrossim, a composição do arcabouço responsável pelo estabelecimento do ambiente 3D pode ser modificada e, assim, influenciar significativamente o estado funcional das diferentes células (COUGOULE et al., 2012; DHIMOLEA et al., 2010). Debnath e Brugge (2005) mostraram que quando as células epiteliais foram cultivadas em ambiente 3D, características do tecido de origem que de outra maneira não eram observadas, passavam a ser identificadas na cultura. $\mathrm{Na}$ verdade, não se pode ignorar a complexidade inerente à matriz extracelular (MEC), uma vez que a decisão final de uma célula para se diferenciar, proliferar, 
migrar, entrar em apoptose ou executar outras funções específicas, é resultado de uma resposta bem coordenada de sua interação com os componentes da MEC e com as células vizinhas (SCHMIDT; FRIEDL, 2010; SCHUPPAN; RÜHL, 1994; STERN et al., 2009).

Frente a estas observações, percebe-se que o estudo em culturas 3D pode trazer informações novas e potencialmente relevantes para a compreensão das diversas interações celulares na resposta imunológica, inclusive daquela induzida pelas células híbridas dendríticas-tumorais usadas em vacinação terapêutica antitumoral por nosso grupo. Serão estas células capazes de interagir e/ou ativar, preferencialmente, uma ou outra subpopulação linfocitária? O padrão de interações é influenciado por modificações nas DCs ou nos diferentes componentes da matriz? Para responder a estas questões, culturas em ambientes 3D são essenciais e podem acrescentar novas variáveis ao estudo da imunoterapia do câncer.

De modo geral, as principais propriedades estruturais de biomateriais desejadas para a construção de um cultivo 3D são a permeabilidade (para permitir o crescimento e a organização celular), porosidade (para manter as células em sua conformação natural) e a conectividade (para permitir o fluxo livre de oxigênio e nutrientes em torno da massa de células em crescimento) (LEE; CUDDIHY; KOTOV, 2008). Outra propriedade importante para a criação de um ambiente 3D é a utilização de diferentes componentes da MEC que podem ou não ser utilizados em associação com os biomateriais com o objetivo criar uma maior semelhança com as condições de um organismo vivo (LEE; CUDDIHY; KOTOV, 2008; PAGE; FLOOD; REYNAUD, 2013). Entre os componentes utilizados comumente, podemos destacar os colágenos e o Matrigel. O Matrigel é composto por diversas proteínas estruturais, proteoglicanos e fatores de crescimento que se assemelham ao ambiente extracelular encontrado em muitos tecidos (KLEINMAN; MARTIN, 2005). Além dos componentes já presentes no Matrigel, outro integrante essencial da MEC são os colágenos. Apesar de diversos estudos demonstrarem que a estrutura de colágeno tipo I é capaz de dar suporte à organização celular (COUGOULE et al., 2012; GUNZER et al., 2000a,b; TASAKI et al., 2004), sabe-se que o colágeno do tipo III é capaz de promover a migração de células da hipófise (GONZÁLEZ et al., 2004) e é o principal componente da matriz do linfonodo, em especial das regiões cortical e paracortical (KRAMER; ROSEN; MECDONALD, 1988), podendo estar envolvido com a migração celular nestes compartimentos. Surpreendentemente, sabendo-se que as interações DC-linfócitos ocorrem nessas regiões, não existem trabalhos referentes às interações imunológicas em 3D utilizando o colágeno III ou ainda alguma mistura de outros componentes de matriz tipicamente presentes em órgãos reticulares.

Assim, no presente estudo, pretende-se acrescentar novos aspectos à análise funcional 
das células híbridas dendríticas-tumorais utilizadas em vacinação antitumoral. Entre estes, a contribuição das variáveis dimensionais e de composição da matriz onde as interações ocorrem, podem, além de aprofundar a compreensão da fisiologia deste sistema terapêutico, oferecer novas estratégias de modulação e aperfeiçoamento da abordagem. 
2 OBJETIVOS 


\section{OBJETIVOS}

O objetivo geral do presente estudo foi investigar as interações celulares entre células híbridas dendríticas-tumorais com diferentes subpopulações de linfócitos $\mathrm{T}$ em um ambiente tridimensional com ou sem substratos.

Especificamente, pretendeu-se:

a) Escolher o melhor ambiente 3D e o melhor tipo de análise das interações celulares;

b) Padronizar o cocultivo de DCs e diferentes subpopulações de linfócitos $\mathrm{T}$ em ambiente 3D;

c) Analisar a porcentagem, o tipo e o tempo de duração das interações celulares;

d) Analisar a velocidade de migração celular antes e depois das interações celulares;

e) Analisar o perfil funcional das coculturas através da produção de citocinas e a proliferação celular de linfócitos T;

f) Analisar todos os parâmetros supracitados em coculturas de células híbridas dendríticas-tumorais e diferentes subpopulações de linfócitos $\mathrm{T}$ no ambiente 3D padronizado. 
3 MATERIAIS e MÉTODOS 


\section{MATERIAIS E MÉTODOS}

\subsection{Casuística}

Foram utilizadas células mononucleares do sangue periférico (PBMCs) coletadas de 30 doadores saudáveis e obtidas através de câmaras de leucorredução durante o procedimento de aférese, o qual é realizado no Banco de Sangue do Hospital Alemão Oswaldo Cruz, após consentimento por escrito dos doadores. Como critérios de inclusão e exclusão, foram considerados aqueles estabelecidos rotineiramente pelo banco de sangue. Foram utilizadas também 8 pacientes do sexo feminino que apresentaram diagnóstico de adenocarcinoma ductal invasivo de mama com tumores ressecáveis e que voluntariamente se propuseram a participar do estudo, assinando termo de consentimento livre e esclarecido no Hospital Pérola Byington. Foram coletadas amostras de tumores frescos assepticamente obtidos por ressecção cirúrgica $\left(\geq 1 \mathrm{~cm}^{3}\right)$ de lesão primaria ou metastática e ainda, foram coletados $30 \mathrm{~mL}$ do sangue da paciente em tubo com anticoagulante (Tabela 1).

Este projeto foi aprovado pela Comissão de Ética em Pesquisas em Seres Humanos do ICB-USP (número 078.2010) e pela Direção de Ensino do Hospital Pérola Byington (número $045 / 11)$.

Tabela 1 - Pacientes incluídas no estudo. Na tabela encontram-se dados demográficos das pacientes estudadas.

\begin{tabular}{|c|l|c|l|l|}
\hline Pacientes & \multicolumn{1}{|c|}{ Sexo } & Idade & \multicolumn{1}{|c|}{ Diagnóstico } & Quimioterapia \\
\hline P1 & Feminino & 70 anos & $\begin{array}{l}\text { Carcinoma Ductal Invasivo } \\
\text { grau histológico 3 e grau nuclear 3 }\end{array}$ & 6 ciclos \\
\hline P2 & Feminino & 44 anos & $\begin{array}{l}\text { Carcinoma Ductal Invasivo } \\
\text { grau histológico 2 e grau nuclear 3 }\end{array}$ & Não \\
\hline P3 & Feminino & 51 anos & $\begin{array}{l}\text { Carcinoma Ductal Invasivo } \\
\text { grau histológico 3 e grau nuclear 3 }\end{array}$ & Não \\
\hline P4 & Feminino & 57 anos & $\begin{array}{l}\text { Carcinoma Ductal Invasivo } \\
\text { grau histológico 3 e grau nuclear 3 }\end{array}$ & Não \\
\hline P5 & Feminino & 47 anos & $\begin{array}{l}\text { Carcinoma Ductal Invasivo } \\
\text { grau histológico 2 e grau nuclear 2 }\end{array}$ & n ciclos \\
\hline P6 & Feminino & 74 anos & $\begin{array}{l}\text { Carcinoma Ductal Invasivo } \\
\text { grau histológico 2 e grau nuclear 2 }\end{array}$ & 6 ciclos \\
\hline P7 & Feminino & 50 anos & $\begin{array}{l}\text { Carcinoma Ductal Invasivo } \\
\text { grau histológico 2 e grau nuclear 2 }\end{array}$ & 6 ciclos \\
\hline P8 & Feminino & 46 anos & $\begin{array}{l}\text { Carcinoma Ductal Invasivo } \\
\text { grau histológico 1 e grau nuclear 2 }\end{array}$ \\
\hline
\end{tabular}




\subsection{Diferenciação de células dendríticas in vitro a partir de monócitos derivados de sangue periférico.}

As câmaras de leucorredução e o sangue das pacientes, devidamente lacrados e estéreis, foram transportados à temperatura ambiente para o Laboratório de Imunologia de Tumores do Instituto de Ciências Biomédicas da Universidade de São Paulo, onde o material foi processado.

O conteúdo das câmaras de leucorredução e do sangue das pacientes foi diluído em Salina Tamponada com Fosfato (PBS; Sigma-Aldrich, St. Louis, Missouri, EUA) pH 7,2, na proporção de 1:1. Em seguida, o conteúdo foi vigorosamente ressuspenso e transferido para outro tubo já contendo $12 \mathrm{~mL}$ de Ficoll-Paque Plus (GE Healthcare, Uppsala, Suécia). Em seguida, o material foi centrifugado a $900 \mathrm{~g}$ com 0 de frenagem e temperatura de $18^{\circ} \mathrm{C}$ por 30 minutos. Logo após a centrifugação, foi retirada a camada de células mononucleares e estas foram ressuspensas juntamente com o meio RPMI-1640 (Life Technologies ${ }^{\mathrm{TM}}$, Carlsbad, CA, EUA). A solução foi novamente centrifugada a $290 \mathrm{~g}$ com frenagem e temperatura de $18{ }^{\circ} \mathrm{C}$ por 10 minutos. Foram então feitas duas lavagens com RPMI-1640, intercaladas de centrifugações de $244 \mathrm{~g}$ e $163 \mathrm{~g}$, respectivamente. O precipitado foi coletado e ressuspenso em meio de cultura AIM-V (GIBCO by Life Technologies, Carlsbad, CA, EUA). Uma alíquota da suspensão celular foi coletada para quantificação das células mononucleares em câmara de Neubauer.

Após quantificação, as células $\mathrm{CD}_{1} 4^{+}$das câmaras de leucorredução foram separadas a partir das PBMCs por seleção negativa em coluna imunomagnética, através do kit Monocyte Isolation Kit II human (Miltenyi Biotec, Bergisch Gladbach, Alemanha). Resumidamente, 1 x $10^{7}$ células foram centrifugadas a $300 \mathrm{~g}$ por 10 minutos à $4^{\circ} \mathrm{C}$. Em seguida, o sobrenadante foi retirado e as células foram ressuspensas em $30 \mu \mathrm{L}$ de tampão apropriado (PBS suplementado com 0,5\% de albumina sérica bovina (BSA; Sigma-Aldrich), pH 7,2, e $2 \mathrm{mM}$ ácido etilenodiamino tetra-acético (EDTA; Sigma-Aldrich), $4-8^{\circ} \mathrm{C}$ ). Logo após, $10 \mu \mathrm{L}$ do reagente bloqueador de FcR e $10 \mu \mathrm{L}$ do coquetel de anticorpos biotinilados (anti-CD3, CD7, CD16, CD19, CD56, CD123 e glicoforina A) foram adicionados. Após uma leve agitação, as células foram incubadas por 10 minutos à $4{ }^{\circ} \mathrm{C}$. Em seguida, $30 \mu \mathrm{L}$ de tampão e $20 \mu \mathrm{L}$ de microesferas anti-biotina foram adicionados, misturados e incubados por mais 15 minutos à temperatura de $4{ }^{\circ} \mathrm{C}$. Decorrido o tempo, as células foram lavadas com $2 \mathrm{~mL}$ de tampão e centrifugadas a $300 \mathrm{~g}$ por 10 minutos. Logo após a retirada do sobrenadante, as células foram ressuspensas em $500 \mu \mathrm{L}$ de tampão e foram aplicadas na coluna imunomagnética MS por 
duas vezes, obtendo somente monócitos $\mathrm{CD} 14^{+}$, que foram usados em ensaios posteriores. Já as células das pacientes foram congeladas $\left(90 \%\right.$ de Soro Fetal Bovino (SFB; Invitrogen ${ }^{\mathrm{TM}}$, Carlsbad, EUA) e 10\% de Dimetilsulfóxido (DMSO, Sigma-Aldrich) antes do procedimento de separação por colunnomagnética.

Após a separação dos monócitos pela coluna imunomagnética, estes foram plaqueados na concentração de até $1 \times 10^{6}$ células $/ \mathrm{mL}$ e mantidos na estufa a $37^{\circ} \mathrm{C}$ com $5 \%$ de $\mathrm{CO}_{2}$ para diferenciação em DCs. Os monócitos foram mantidos em meio de cultura AIM-V acrescido de $50 \mathrm{ng} / \mathrm{mL}$ de interleucina-4 (IL-4; PeproTech, EUA) e $50 \mathrm{ng} / \mathrm{mL}$ de Fator Estimulador de Colônia de Macrófagos e Granulócitos (GM-CSF; PeproTech) para a diferenciação dos monócitos em DCs imaturas (0h-DCs). Após 5 dias, as células foram ativadas pela adição de 50 ng/mL de Fator de Necrose Tumoral $\alpha$ (TNF- $\alpha$; PeproTech) para a obtenção de DCs maduras (48h-mDCs).

Visto que resultados não publicados do nosso grupo mostram um início do processo de maturação da DC já após 2 horas de tratamento com TNF- $\alpha$, incluímos este tratamento aos experimentos realizados. Este grupo foi denominado aqui como $2 \mathrm{~h}-\mathrm{mDCs}$, diferente ao tratamento convencional de 48 horas com TNF- $\alpha$, aqui denominado como $48 \mathrm{~h}-\mathrm{mDCs}$.

No sétimo dia de cultura, 0h-DCs, $2 \mathrm{~h}-\mathrm{mDC}$ e $48 \mathrm{~h}-\mathrm{mDC}$ foram colhidas e utilizadas nos diferentes experimentos.

\subsection{Separação imunomagnética de linfócitos $\mathbf{T} \mathbf{C D 3}^{+}$}

Linfócitos congelados a partir de culturas anteriores (obtidos de câmaras de leucorredução e do sangue das pacientes ambas separadas por gradiente de densidade) foram submetidos à separação imunomagnética. Utilizamos colunas magnéticas através do kit Pan T Cell Isolation Kit II (Miltenyi Biotec). Resumidamente, 1 x $10^{7}$ de linfócitos foram centrifugados a $300 \mathrm{~g}$ por 10 minutos. Em seguida, o sobrenadante foi retirado e as células foram ressuspensas em $40 \mu \mathrm{L}$ de tampão apropriado (PBS-BSA 0,5\%, pH 7,2, e $2 \mathrm{mM}$ EDTA, $4-8{ }^{\circ} \mathrm{C}$ ). Logo após, $10 \mu \mathrm{L}$ do coquetel de anticorpos biotinilados (anti-CD14, CD16, CD19, CD36, CD56, CD123 e glicoforina A) foram adicionados, agitados e incubados por 10 minutos à $4{ }^{\circ} \mathrm{C}$. Após esse período, foram adicionados mais $30 \mu \mathrm{L}$ de tampão e $20 \mu \mathrm{L}$ de microesferas anti-biotina. Em seguida, o tubo contendo as células e os reagentes foram misturados e incubados por mais 15 minutos à temperatura de $4{ }^{\circ} \mathrm{C}$. Decorrido o tempo necessário, o volume foi completado para $10 \mathrm{~mL}$ com tampão e centrifugado a $300 \mathrm{~g}$ por 10 minutos. Por fim, o sobrenadante foi retirado e as células foram ressuspensas em $500 \mu \mathrm{L}$ de 
tampão, procedendo então à passagem através da coluna imunomagnética LS, obtendo somente linfócitos $\mathrm{T} \mathrm{CD}^{+}$, os quais foram usados em ensaios posteriores.

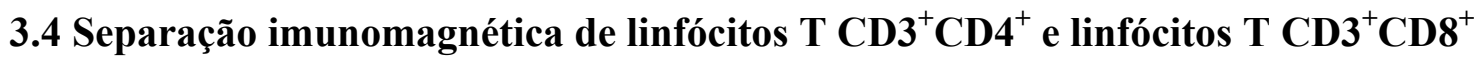

Após separação em coluna imunomagética, linfócitos $\mathrm{T} \mathrm{CD}^{+}$foram novamente contados em câmaras de Neubauer e os linfócitos $\mathrm{CD} 4^{+}$foram separados por seleção positiva em coluna imunomagnética, através do kit CD4 Microbeads (Miltenyi Biotec). Resumidamente, 1 x $10^{7}$ de linfócitos foram centrifugados a $300 \mathrm{~g}$ por 10 minutos. Em seguida, o sobrenadante foi retirado e as células foram ressuspensas em $80 \mu \mathrm{L}$ de tampão apropriado (PBS-BSA 0,5\%, pH 7,2, e $2 \mathrm{mM}$ EDTA, 4- $8^{\circ} \mathrm{C}$ ). Logo após, $20 \mu \mathrm{L}$ de CD4 microesferas foram adicionados, agitados e incubados por 15 minutos à $4^{\circ} \mathrm{C}$. Decorrido o tempo necessário, o volume foi completado para $2 \mathrm{~mL}$ com tampão e centrifugado a $300 \mathrm{~g}$ por 10 minutos. Por fim, o sobrenadante foi retirado e as células foram ressuspensas em $500 \mu \mathrm{L}$ de tampão, procedendo então à passagem através da coluna imunomagnética LS. Por se tratar de uma separação positiva, linfócitos $\mathrm{CD}^{+}$aderidos na coluna imunomagnética foram retiradas com o auxílio de um êmbolo. Já as células que atravessaram a coluna se tratavam de linfócitos $\mathrm{T} \mathrm{CD}^{+}$. Essas células foram novamente centrifugadas a $300 \mathrm{~g}$ por 10 minutos, o sobrenadante foi retirado e as células foram ressuspensas novamente em $500 \mu \mathrm{L}$ de tampão, procedendo mais uma vez a passagem através da coluna imunomagnética LS. Após a separação, linfócitos $\mathrm{T} \mathrm{CD}^{+} \mathrm{CD}^{+}$e $^{\mathrm{CD}} 3^{+} \mathrm{CD} 8^{+}$foram mantidos em meio de cultura RPMI1640 suplementado com $10 \%$ de SFB originando o meio de cultura R-10 por 24 horas e utilizados em ensaios posteriores.

\subsection{Avaliação por citometria de fluxo da pureza das populações de monócitos e linfócitos}

Para determinação da pureza de linfócitos e monócitos, esferas magnéticas marcadas com os anticorpos monoclonais foram utilizadas para ajustar a voltagem dos lasers no citômetro de fluxo (BD FACSCanto ${ }^{\mathrm{TM}}$ II, San Jose, CA, EUA). Para a compensação, realizada no programa de análise FlowJo versão 8.7 (Tree Stars Inc, Ashland, EUA), delimitou-se um gate nas esferas (Figura 1A) e, posteriormente, nos picos negativo e positivo para cada fluorocromo (Figura 1B).

Após a compensação, foi delimitado o gate através dos parâmetros de tamanho (FSC forward scatter) e granulosidade (SSC - side scatter) para a observação das células adquiridas 
sem a presença de debris (Figura 2A). Dentro desta população, foi possível observar os marcadores na superfície das células purificadas (CD3, CD4, CD8, CD14, CD19 e CD56) (Figura 2B). Os anticorpos usados contam na Tabela 2. As aquisições dos dados foram realizadas no citômetro de fluxo FACSCanto $^{\text {TM }}$ II com o programa FACSDiva (BD Biosciences, EUA). Um total de 20000 eventos foram adquiridos/amostra. Os dados obtidos foram analisados usando-se o programa FlowJo versão 8.7. Para cada população, foram avaliadas a porcentagem de células expressando cada marcador .
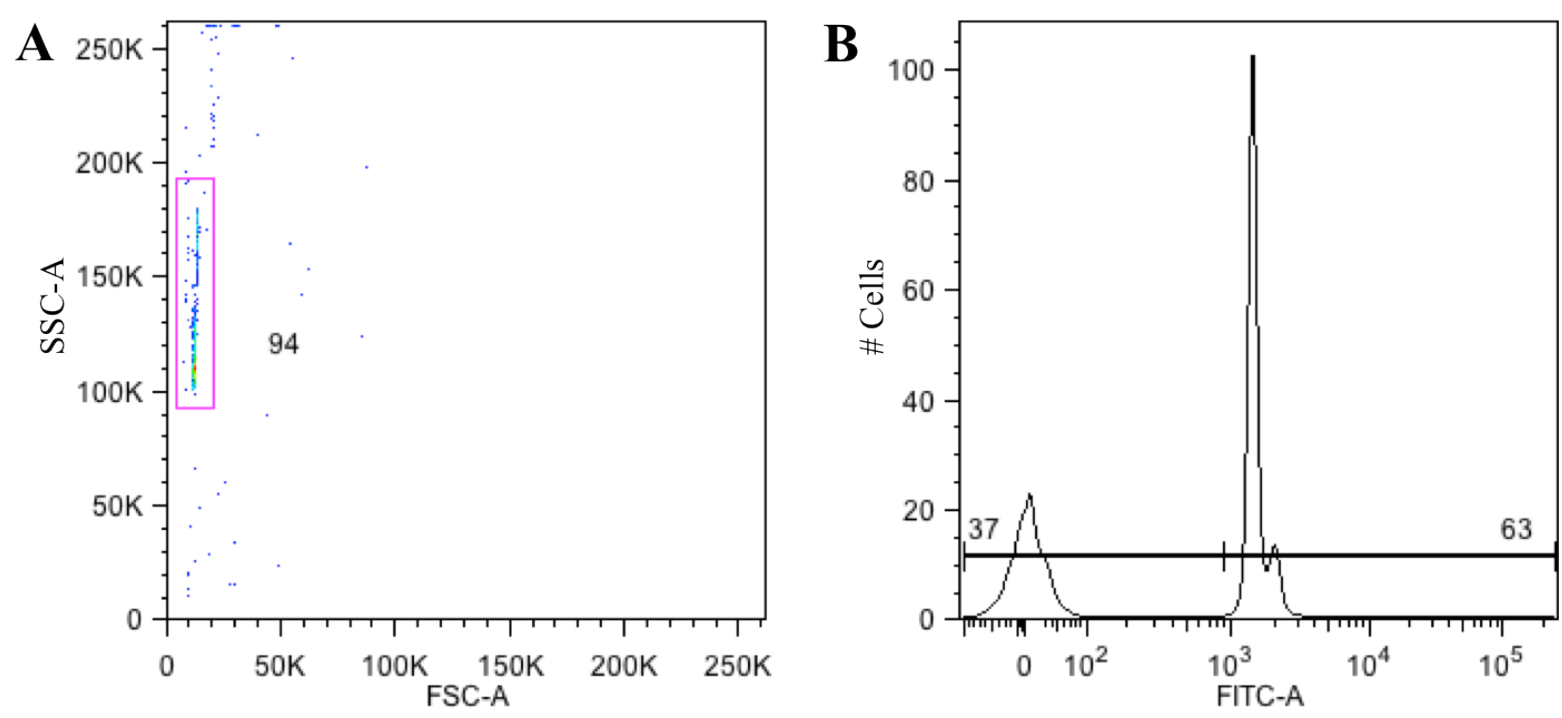

Figura 1 - Método de compensação no programa FlowJo com esferas magnéticas. (A) Gráfico em dot plot demonstrando o gate de análise das esferas magnéticas. (B) Histograma demonstrativo exemplificando o método para compensação do fluorocromo FITC, assim, delimitando a positividade e a negatividade deste fluorocromo 

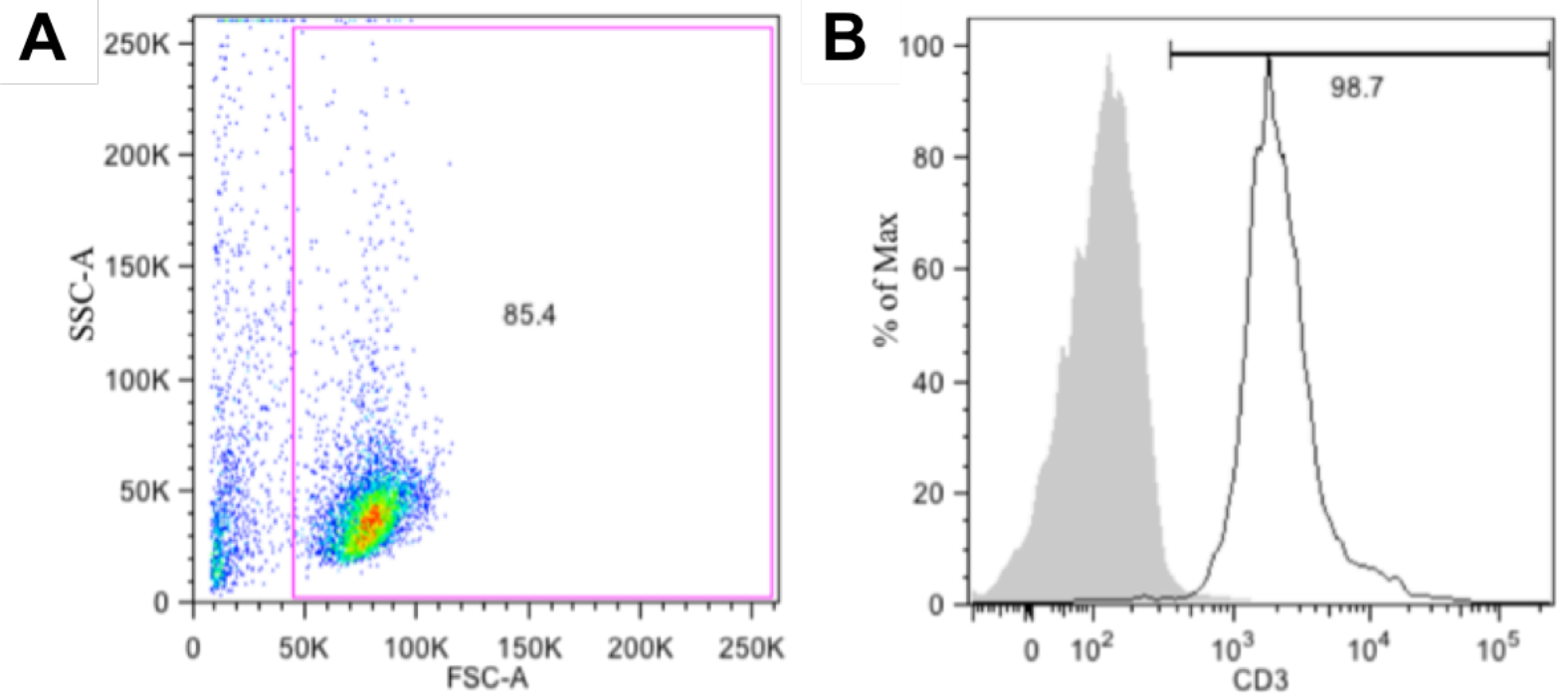

Figura 2 - Método de análise da pureza de linfócitos e monócitos no programa FlowJo. (A) Gráfico dot plot de SSC-A por FCS-A de todas as células adquiridas sem a presença de debris; (B) Histograma mostrando um dos marcadores de interesse (exemplo a molécula CD3). No histograma as células não marcadas estão representadas em cinza e as marcadas, em preto.

Tabela 2 - Anticorpos monoclonais utilizados para avaliação da pureza de monócitos,

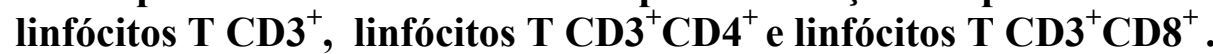

\begin{tabular}{|c|c|c|c|}
\hline Especificidade & Clone & Isótipo/Origem & Marcação \\
\hline CD3 & $\mathrm{H} 1 \mathrm{~T} 3 \mathrm{a}$ & $\mathrm{IgG}_{2 \mathrm{a}} \mathrm{k} /$ camundongo & $\mathrm{APC}$ \\
\hline CD4 & $\mathrm{RPA}-\mathrm{T} 4$ & $\mathrm{IgG}_{1} \mathrm{k} /$ camundongo & $\mathrm{PE}$ \\
\hline CD8 & $\mathrm{SK} 1$ & $\mathrm{IgG}_{1} \mathrm{k} /$ camundongo & PerCP \\
\hline CD14 & $\mathrm{M} 5 \mathrm{E} 2$ & $\mathrm{IgG}_{2 \mathrm{a}} \mathrm{k} /$ camundongo & $\mathrm{FITC}$ \\
\hline CD19 & $\mathrm{SJ} 25 \mathrm{C} 1$ & $\mathrm{IgG}_{1} \mathrm{k} /$ camundongo & $\mathrm{APC}-\mathrm{Cy} 7$ \\
\hline CD56 & $\mathrm{B} 159$ & $\mathrm{IgG}_{1} \mathrm{k} /$ camundongo & $\mathrm{V} 450$ \\
\hline
\end{tabular}

\subsection{Avaliação do fenótipo de membrana de monócitos e das DCs por citometria de fluxo}

Para determinação do fenótipo de membrana, até $2 \times 10^{5}$ células (monócitos, 0h-DCs, 2h-mDCs e 48h-mDCs) obtidas das culturas foram separadas em alíquotas. Em seguida, foram lavadas duas vezes por 30 segundos a $17949 \mathrm{~g}$ para obtenção de um precipitado, ao qual foram adicionados anticorpos monoclonais comerciais (BD Biosciences) contra os seguintes marcadores: CD1a, CD11c, CD14, CD40, CD80, CD83, CD86, CD209, CCR7, PD- 
L1 e HLA-DR. Além disso, foi utilizado o corante violeta LIVE/DEAD (Life Technologies ${ }^{\mathrm{TM}}$ ) para a análise de viabilidade celular. A descrição detalhada dos anticorpos é mostrada no Tabela 3. As células foram incubadas por 20 minutos a $4^{\circ} \mathrm{C}$ no escuro. Após este período, o material foi lavado por 2 vezes (30 segundos, $17949 \mathrm{~g}$ ) com $200 \mu \mathrm{L}$ de tampão para citometria (PBS-BSA 0,5\% e 0,02\% de azida sódica). Após as lavagens, as células já marcadas, foram ressuspensas em $400 \mu \mathrm{L}$ de tampão de fixação $(0,5 \%$ de BSA, $0,02 \%$ de azida sódica e $2 \%$ formaldeído em PBS). As análises foram realizadas no citômetro de fluxo FACSCanto $^{\text {TM }}$ II com o programa FACSDiva. Um total de 20000 eventos foram adquiridos/amostra. Os dados obtidos foram analisados usando-se o programa FlowJo versão 8.7. Para cada população, foram avaliadas a porcentagem de células expressando cada marcador e a intensidade mediana de fluorescência (MFI) relativa. A MFI relativa foi calculada dividindo-se a MFI da população positiva para cada marcador pela MFI do tubo sem marcação.

Tabela 3 - Anticorpos monoclonais utilizados para avaliação do fenótipo de membrana dos monócitos e das DCs (dos grupos 0h-DCs, 2h-mDCs e 48h-mDCs).

\begin{tabular}{|c|c|l|c|}
\hline Especificidade & Clone & Isótipo/Origem & Marcação \\
\hline CD1a & H1149 & IgG1 k/ camundongo & FITC \\
\hline CD11c & B-Ly6 & IgG1 k/ camundongo & APC \\
\hline CD14 & M $\varphi$ P9 & IgG2b k/ camundongo & APC-Cy ${ }^{\mathrm{TM}} 7$ \\
\hline CD40 & $5 \mathrm{C} 3$ & IgG1 k/ camundongo & APC-H7 \\
\hline CD80 & L307.4 & IgG1 k/ camundongo & PE \\
\hline CD83 & HB15e & IgG1 k/ camundongo & PE \\
\hline CD86 & $2331(\mathrm{FUN}-1)$ & IgG1 k/ camundongo & FITC \\
\hline CD209 & DCN46 & IgG2b k/ camundongo & FITC \\
\hline CCR7 & $3 \mathrm{D} 12$ & IgG2a k/ camundongo & PeCy7 \\
\hline PD-L1 & MIH1 & IgG1 k/ camundongo & PE \\
\hline HLA-DR & G46-6 & IgG2a k/ camundongo & V500 \\
\hline
\end{tabular}


Como estratégia de análise para monócitos e os diferentes grupos de DCs, o ajuste da voltagem dos lasers e a compensação foi realizada como descrito nas Figuras 1A e B. Após a compensação, foi delimitado o gate de SSC por FSC (Figura 3A) e, em seguida, foi delimitado outro gate baseado na área (FSC A-forward scatter area) pela altura (FSC H) na população com característica linear para seleção de singlets (Figura 3B). No caso da fenotipagem das DCs, delimitou-se a região de SSC por SSC característicos destas células e foram excluídos os debris celulares (Figura 3C). Dentro deste gate, um gráfico dot plot foi gerado mostrando a viabilidade celular. Neste gráfico, podemos observar 2 populações distintas, o da esquerda determina as células vivas e o da direita, as células mortas (Figura 3D). Dentro das células vivas, delimitou-se então um gate na população que possuía os marcadores de superfície CD11c ${ }^{+}$e $\mathrm{HLA}_{-D R}{ }^{+}$(Figura 3E). Dentro desta população duplopositiva (CD11 $\left.\mathrm{c}^{+} \mathrm{HLA}-\mathrm{DR}^{+}\right)$, foi possível analisar os marcadores de superfície característicos de DCs (CD1a, CD14, CD40, CD80, CD83, CD86, CD209, CCR7 e PD-L1). Já para monócitos, esses mesmos marcadores foram analisados diretamente no gate delimitado para células vivas. 

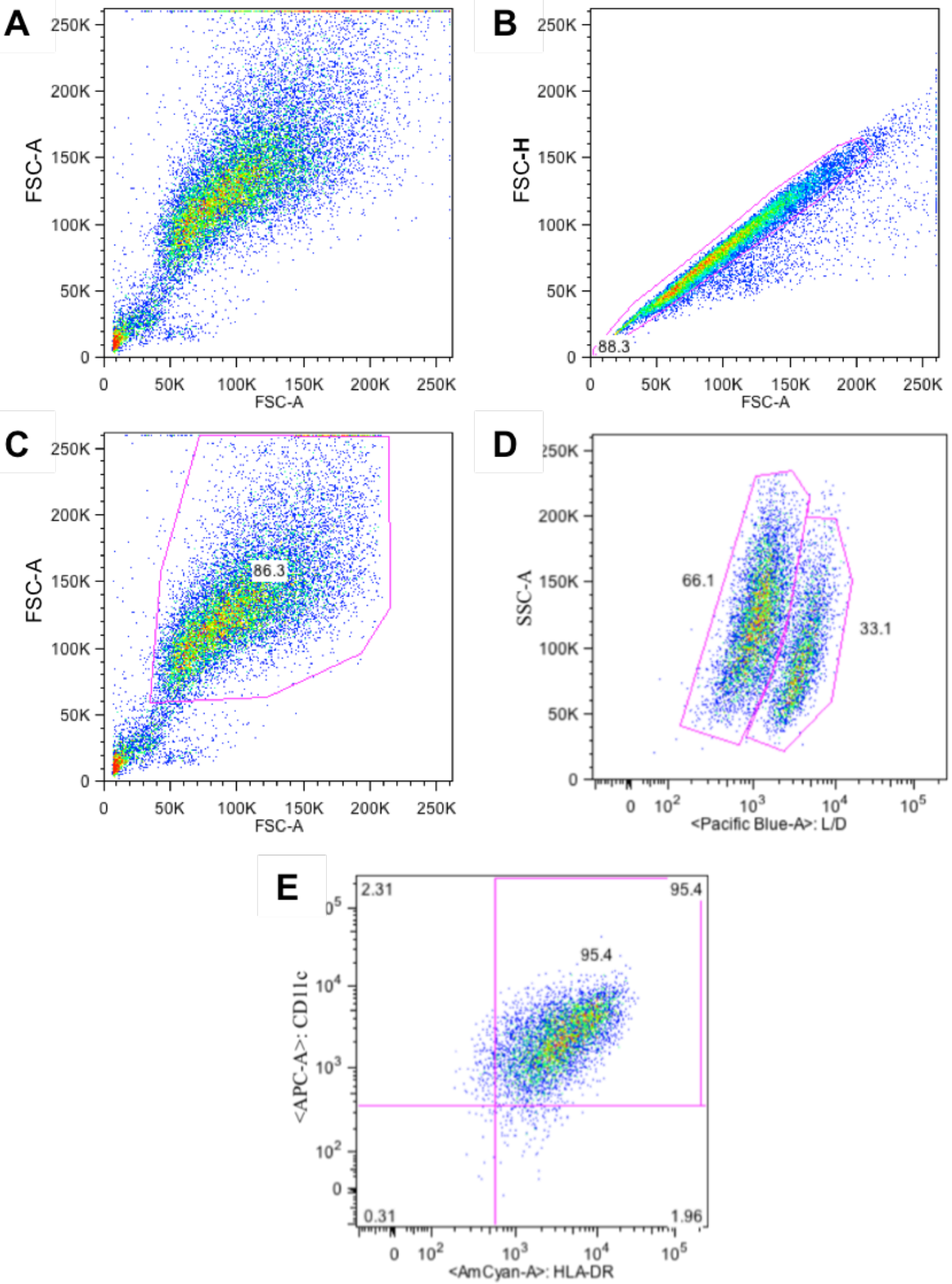

Figura 3 - Método de análise da fenotipagem de DCs. (A) Gráfico dot plot de granulosidade (SSC-A) por tamanho (FCS-A) de todas as células adquiridas; (B) Gráfico dot plot de FCS-H por FCS-A mostrando o gate com eventos únicos (singlets); (C) Gráfico dot plot de SSC-A por FCS-A delimitando o gate, o qual representa a população com tamanho e granulosidade característicos das células de interesse; (D) Gráfico dot plot mostrando a viabilidade celular, demonstrando células vivas do lado esquerdo e mortas do lado direito; (E) Gráfico em dot plot mostrando a população duplo positiva para os marcadores CD11c e HLA-DR dentro do gate de células vivas. 


\subsection{Obtenção dos Animais}

Os linfonodos de camundongos foram gentilmente cedidos pela Dra. Jacqueline de Fátima Jacysyn da Faculdade de Medicina da Universidade de São Paulo. Foram utilizados linfonodos inguinais de camundongos macho Balb/c de 6-8 semanas.

\subsubsection{Coloração por Picro-Sírius para a identificação de Fibras Colágenas}

O protocolo para coloração por Picro-Sírius foi previamente baseado no trabalho de Montes e Junqueira de 1991. Corte histológicos de linfonodos de camundongos foram desparafinizados através de duas lavagens de xilol e, logo após, foi feita a hidratação utilizando sucessivas lavagens de etanol em concentrações decrescentes de 100\%, 95\%, 70\%, seguidas de uma lavagem de água destilada.

Em seguida, as amostras foram coradas por uma solução de $0,1 \%$ de Sirius Red F3BA (Sigma-Aldrich) em uma solução aquosa saturada de ácido pícrico por 1 hora em temperatura ambiente. A diferenciação foi realizada utilizando ácido clorídrico (Synth, EUA) a 0,01N por 30 minutos e foi seguida da desidratação em lavagens com concentração crescentes de etanol a $70 \%, 95 \%$, e $100 \%$, diafanizadas utilizando lavagens de xilol e montadas sob lamínula em goma de Dammar.

\subsubsection{Imunofluorescência}

Para confirmar a composição colágena da região de interesse do linfonodo, foram realizadas reações de imunofluorescência para colágeno III e colágeno I. Linfonodos murinos das regiões inguinais foram fixados em solução de paraformaldeído 4\% em PBS por 24 horas. As amostras foram desidratadas em concentrações crescentes de etanol, diafanizadas com xilol e incluídas em Histosec (Merck, Darmstadt, Alemanha). Cortes histológicos com $5 \mu \mathrm{m}$ de espessura foram realizados através de um micrótomo e depositados sobre lâminas histológicas revestidas previamente com 3-aminopropil-trietoxisilano (Sigma-Aldrich). Após a desparafinização com xilol, a hidratação em concentrações decrescentes de etanol e lavagem em água destilada, os cortes foram incubados em gelatina de pele de peixe a 0,05\% (SigmaAldrich) em PBS por 1 hora para bloqueio dos sítios antigênicos inespecíficos e, logo após, em PBS contendo 3\% de glicina por 1 hora para redução de autofluorescência. Em seguida, 
anticorpos primários anti- I e anti-colágeno III (ambos gentilmente doados pela Profa. Dra. Telma Zorn do Departamento de Biologia Celular e do Desenvolvimento ICB/USP- 1:50, Rockland, EUA) foram diluídos em pele de peixe a 0,05\% em PBS e incubados nos cortes por uma noite a $4{ }^{\circ} \mathrm{C}$. Após lavagens com PBS, o anticorpo secundário anti-coelho conjungado com FITC (1:200; Sigma-Aldrich) foi diluído em pele de peixe a 0,05\% em PBS e incubado nos cortes por 1 hora em temperatura ambiente. Em seguida, foram realizadas lavagens com PBS e os cortes montados com Vectashield/4',6-diamino-2-fenilindol (DAP-I, Vector Laboratories, Burlingame, EUA) em lamínula. Como controles negativos, os anticorpos primários foram omitidos ou substituídos por uma IgG Isotype Control (Abcam, Cambridge, Reino Unido).

\subsection{Testes com diferentes tipos de matrizes 3D}

Com o intuito de escolher o melhor ambiente tridimensional para estudar a interação entre linfócitos e células dendríticas avaliaram-se três arcabouços diferentes: Algimatrix (Invitrogen $^{\mathrm{TM}}$ ), Cell Fate hidrogel (gentilmente cedidas pelo Prof. Dr. Luizmar Porto Universidade Federal de Santa Catarina) e 3D Biotek (Biotek ${ }^{\mathrm{TM}}$, North Brunswick Township, EUA).

Células alvo e efetoras cocultivadas em ambiente tridimensional Algimatrix e o Cell Fate Hydrogel foram fixadas em formol 10\% em PBS por 20 minutos. Em seguida foram realizadas duas lavagens em PBS. Logo depois foi realizada a etapa de bloqueio com Soro Normal de Cabra (KPL, Gaithersburg, MD, EUA) por 20 minutos. Após esse período as células cocultivadas foram marcadas com os seguintes anticorpos para citometria de fluxo: CD3 e CD11c. A descrição detalhada dos anticorpos é mostrada no Tabela 4. Por fim as células foram lavadas em PBS e as lâminas foram montadas com Prolong (Invitrogen ${ }^{\mathrm{TM}}$ ).

Com relação ao arcabouço $3 \mathrm{D}$ Biotek as células foram fixadas em $4 \%$ de paraformaldeído em PBS por 20 minutos. Em seguida foi realizada lavagem em PBS e permeabilização com $0.5 \%$ de Triton X-100 (Sigma-Aldrich) em PBS por 10 minutos. As células foram então submetidas novamente a duas lavagens em PBS. Logo após, foi adicionada RNAse por 20 minutos a $37^{\circ} \mathrm{C}$, seguindo-se lavagem com PBS. Após esse período as células foram marcadas com o faloidina-Alexa 488 (Invitrogen ${ }^{\mathrm{TM}}$ ) por um período de 20 minutos no escuro e lavadas duas vezes consecutivas com PBS. Todos os resultados foram analisados por microscopia confocal de varredura a laser (microscópio Zeiss LSM 510, Jena, Alemanha). 
Tabela 4 - Anticorpos monoclonais utilizados em testes de interações celulares.

\begin{tabular}{|c|c|c|c|}
\hline Especificidade & Clone & Isótipo/Origem & Marcação \\
\hline CD3 & HIT3a & $\operatorname{IgG}_{2 \mathrm{a}} \mathrm{k} /$ camundongo & FITC \\
\hline CD11c & B-Ly6 & $\operatorname{IgG}_{1} \mathrm{k} /$ camundongo & PE \\
\hline
\end{tabular}

\subsection{Interações celulares entre DCs e linfócitos T em ambiente 3D}

\subsubsection{Marcação de linfócitos T com Carboxifluoresceína succinimidil éster (CFSE)}

Para a identificação de linfócitos $\mathrm{T} \mathrm{CD}^{+} \mathrm{CD}^{+}$em ambiente 3D foi utilizado o corante Carboxifluoresceína succinimidil éster (CFSE; Molecular Probes ${ }^{\circledR}$ by Life Technologies ${ }^{\mathrm{TM}}$, Eugene, Oregon, EUA), um corante que nas condições de microscopia é observado em verde. Para isso, até $5 \times 10^{6}$ linfócitos T foram incubados em tampão contendo $0,5 \%$ de BSA e 10 $\mu \mathrm{M}$ do CFSE em PBS. A incubação foi feita a $37^{\circ} \mathrm{C}$ por 10 minutos, no escuro. Após esse período, as células foram mantidas em meio de cultura R-10 e, em seguida, incubadas a $4{ }^{\circ} \mathrm{C}$ por 5 minutos. A solução foi então centrifugada duas vezes a $800 \mathrm{~g}$ por 7 minutos e as células foram mantidas em meio de cultura R-10 por 48 horas para experimento posterior.

\subsubsection{Marcação de linfócitos T com CellTracker Orange}

Linfócitos $\mathrm{T} \mathrm{CD}^{+} \mathrm{CD}^{+}$alogenêicos de doadores saudáveis ou linfócitos $\mathrm{T} \mathrm{CD}^{+} \mathrm{CD}^{+}$ de pacientes com câncer de mama, foram corados com o corante CellTracker Orange (Molecular Probes ${ }^{\circledR}$ by Life Technologies ${ }^{\mathrm{TM}}$ ) um corante vital fluorescente laranja. Resumidamente, os linfócitos foram quantificados, diluídos em PBS-BSA 0,5\% pré-aquecido e centrifugados a $300 \mathrm{~g}$ por 10 minutos. A incubação foi feita a $37^{\circ} \mathrm{C}$ por 15 minutos no escuro e com $10 \mu \mathrm{M}$ do corante em PBS-BSA 0,5\%. Após esse período, as células foram centrifugadas a $17949 \mathrm{~g}$ por 20 segundos. Logo após a centrifugação, o sobrenadante foi retirado e as células foram ressuspensas em $1 \mathrm{~mL}$ de meio de cultura $\mathrm{R}-10$. Novamente as células foram centrifugadas a $17949 \mathrm{~g}$ por 20 segundos. Em seguida, as células foram incubadas a temperatura ambiente por 30 minutos em meio de cultura R-10. Por fim, as células foram novamente centrifugadas a $17949 \mathrm{~g}$ por 20 segundos, o sobrenadante foi descartado e o precipitado celular ressuspenso em meio de cultura R-10. 


\subsubsection{Marcação de DCs com CellTracker Red}

Os grupos 0h-DCs, 2h-mDCs e 48h-mDCs no sétimo dia de cultura, foram coradas com o corante CellTracker Red (Molecular Probes ${ }^{\circledR}$ by Life Technologies ${ }^{\mathrm{TM}}$ ) um corante vital fluorescente vermelho. Resumidamente, as DCs foram quantificadas, diluídas em PBS-BSA $0,5 \%$ pré-aquecido e centrifugadas a $300 \mathrm{~g}$ por 10 minutos. A incubação foi feita a $37{ }^{\circ} \mathrm{C}$ por 15 minutos, no escuro com $10 \mu \mathrm{M}$ do corante em PBS-BSA 0,5\%. Após esse período, as células foram centrifugadas a $17949 \mathrm{~g}$ por 20 segundos. Logo após a centrifugação, o sobrenadante foi retirado e as células foram ressuspensas em $1 \mathrm{~mL}$ de meio de cultura AIMV. Novamente as células foram centrifugadas a $17949 \mathrm{~g}$ por 20 segundos. Em seguida, as células foram incubadas a temperatura ambiente por 30 minutos em meio de cultura AIM-V. Por fim, as células foram novamente centrifugadas a $17949 \mathrm{~g}$ por 20 segundos, o sobrenadante foi descartado e o precipitado ressuspenso em meio de cultura AIM-V.

\subsection{Fusão Celular}

3.10.1 Digestão e isolamento de células neoplásicas de adenocarcinoma ductal invasivo de mama

Os tumores sólidos foram transportados, a $4{ }^{\circ} \mathrm{C}$ em meio de cultura RPMI-1640 com 1\% de solução antibiótica-antimicótica $(100 \mathrm{U} / \mathrm{mL}$ penicilina, $100 \mu \mathrm{g} / \mathrm{mL}$ estreptomicina e 25

$\mu \mathrm{g} / \mathrm{mL}$ anfotericina; $\mathrm{GIBCO}^{\circledR}$ by Life Technologies ${ }^{\mathrm{TM}}$ ), devidamente lacradas e estéreis para o Instituto de Ciências Biomédicas da Universidade de São Paulo, onde ocorreu o processamento do material.

Primeiramente, as amostras tumorais foram dissociadas com o uso de bisturi e as suspensões de células únicas foram geradas por digestão com colagenase tipo VIII $(1,12$ $\mathrm{mg} / \mathrm{mL}$; Sigma-Aldrich), RPMI-1640 e 0,1\% de solução antibiótica-antimicótica durante 120 minutos de incubação a $37^{\circ} \mathrm{C}$, sob agitação. Após recuperação, as células foram filtradas em gaze e lavadas em RPMI-1640. A viabilidade celular foi avaliada por exclusão com o corante azul de tripan e a média de viabilidade foi de $90 \%$. Em seguida as células foram ressuspensas em meio de congelameto (90\% de SFB e 10\% de DMSO), imediatamente congeladas e mantidas até a sua utilização para a hibridação com DCs. 


\subsubsection{Cultivo da linhagem SKBR-3}

As células da linhagem de adenocarcinoma de mama humano SK-BR-3 foram gentilmente cedidas pela Dra. Anamaria Camargo do Instituto Ludwig-SP, e foram mantidas em nosso laboratório criopreservadas em nitrogênio líquido. Para os ensaios, as células foram descongeladas em banho-maria a $37^{\circ} \mathrm{C}$ e rapidamente transferidas para tubo estéril com 10 $\mathrm{mL}$ de meio cultura R-10 e mantidas na estufa a $37^{\circ} \mathrm{C}$ por 15 minutos. Em seguida as células foram lavadas em R-10 suplementado com 1\% de solução antibiótico-antimicótico. Na sequência, as células foram centrifugadas durante 10 minutos à $300 \mathrm{~g}$. A viabilidade das células foi avaliada, considerando-se um mínimo de 70\% de células vivas para manuseio. Após contagem, as células foram mantidas em frascos de $75 \mathrm{~cm}^{2}$ em atmosfera de $5 \% \mathrm{CO}_{2}$ a $37^{\circ} \mathrm{C}$ até formarem uma monocamada de células até atingirem confluência para o uso quando foram utilizadas como parceiras para fusão com as DCs.

\subsubsection{Marcação de receptores de membrana das células tumorais, SKBR-3 e DCs}

Para caracterização das células híbridas dendríticas-tumorais, até 1 × $10^{6}$ células (DCs, células tumorais ou SKBR-3) obtidas das culturas foram separadas em alíquotas e marcadas, sendo realizado o mesmo procedimento para marcação do fenótipo de membrana descrito anteriormente (Item 3.6). A descrição detalhada dos anticorpos é mostrada Tabela 5. No caso da imagem para caracterização de células híbridas dendríticas-tumorais também foi adicionado Prolong acrescido de DAP-I (Invitrogen ${ }^{\mathrm{TM}}$ ) por 20 minutos. Em seguida, as células foram submetidas ao protocolo de geração de células híbridas descrito a seguir.

Tabela 5 - Anticorpos monoclonais utilizados para marcação das células tumorais, SKBR-3 e das DCs

\begin{tabular}{|c|c|c|c|}
\hline Especificidade & Clone & Isótipo/Origem & Marcação \\
\hline CD11c & B-ly6 & $\operatorname{IgG}_{1} \mathrm{k} /$ camundongo & FITC \\
\hline Her-2/neu & Neu 24.7 & $\operatorname{IgG}_{1} \mathrm{k} /$ camundongo & APC \\
\hline CD209 & DCN46 & $\operatorname{IgG}_{2} \mathrm{~b} \mathrm{k} /$ camundongo & FITC \\
\hline
\end{tabular}




\subsubsection{Geração de células híbridas dendríticas-tumorais}

O protocolo para a geração de células híbridas foi baseado nos trabalhos previamente publicados por nosso grupo (BARBUTO et al., 2004) e por outros (SCOTT-TAYLOR et al., 2000). O grupo 48h-mDCs ( $\left.5 \times 10^{5}\right)$ e as células tumorais ou SKBR-3 (5 x 10 $)$, inicialmente separadas e marcadas com anti-Her-2/neu APC (células tumorais ou SKBR-3) e anti-CD11c FITC (DCs), foram lavadas em solução contendo 5\% de glicose (Cinética Química, Rio de Janeiro, Brasil) e centrifugadas por 10 minutos a $300 \mathrm{~g}$. Em seguida, a mesma concentração de cada tipo de célula, em $250 \mu \mathrm{L}$, foi colocada em uma cubeta de eletroporação (BioRad, Richmond, CA, EUA) com uma de suas placas parcialmete recoberta por parafina e mantida por 5 minutos na cubeta. As células foram alinhadas, por um campo de $100 \mathrm{~V} / \mathrm{cm}$ por 11 segundos e submetidas a um pulso de $1000 \mathrm{~V} / \mathrm{cm}$ a $25 \mu \mathrm{F}$, gerado por um eletroporador Gene Pulser II (BioRad, EUA). Depois do processo de fusão, a cubeta contendo as células foi mantida 5 minutos fora do eletroporador. Logo após, as células foram mantidas por 5 minutos em tampão de relaxamento pH $6.8(10 \mathrm{mM} \mathrm{KCl}, 3 \mathrm{mM} \mathrm{NaCl}, 1.25 \mathrm{mM}$ EDTA, $10 \mathrm{mM}$ PIPES). Após esse período, as células foram centrifugadas a $300 \mathrm{~g}$ por 10 minutos e a $18{ }^{\circ} \mathrm{C}$. Em seguida, foi realizada a quantificação em câmara de Neubauer e a células híbridas marcadas com anti-CD11c e anti-Her-2/neu foram submetidas a separação por coluna imunomagnética anti-FITC, através do kit Anti-FITC Microbeads (Miltenyi Biotec). Resumidamente, até $5 \times 10^{6}$ de células híbridas foram centrifugados a $300 \mathrm{~g}$ por 10 minutos. Em seguida, o sobrenadante foi retirado e as células foram ressuspensas em $45 \mu \mathrm{L}$ de tampão apropriado (PBS-BSA 0,5\%, pH 7,2, e 2 mM EDTA, 4-8 ${ }^{\circ} \mathrm{C}$ ). Logo após, $5 \mu \mathrm{L}$ de microesferas anti-FITC foram adicionados, agitados e incubados por 15 minutos à $4{ }^{\circ} \mathrm{C}$. Decorrido o tempo necessário, o volume foi completado para $2 \mathrm{~mL}$ com tampão e centrifugado a $300 \mathrm{~g}$ por 10 minutos. Em seguida, o sobrenadante foi retirado e as células foram ressuspensas em $500 \mu \mathrm{L}$ de tampão, procedendo então à passagem através da coluna imunomagnética LS.

Logo após a separação, as células híbridas foram ressuspendidas em meio de cultura AIM-V e submetidas a irradiação de 200 Gy no Centro de Tecnologia das Irradiações no Instituto de Pesquisas Energéticas e Nucleares. Após a irradiação as células foram novamente quantificadas e utilizadas em experimentos posteriores.

\subsection{Cocultivo de DCs ou células híbridas e linfócitos T em ambiente 3D}


Para avaliação das coculturas entre DCs em diferentes estágio de maturação e linfócitos $\mathrm{T}$ e células híbridas dendríticas-tumorais e linfócitos $\mathrm{T}$ em ambientes 3D tratados com diferentes componentes da MEC foram estabelecidos as seguintes condições de cultura:

- Sem Col III: Células dendríticas cocultivadas com linfócitos T alogenêicos apenas em matriz 3D Biotek em estufa com $5 \%$ de $\mathrm{CO}_{2}$, a $37{ }^{\circ} \mathrm{C}$.

- Col III: Células dendríticas cocultivadas com linfócitos T alogenêicos em matriz 3D Biotek tratada com colágeno tipo III $(0,4 \mu \mathrm{g} / \mu \mathrm{L})$ (BD Bioscience) em estufa com $5 \%$ de $\mathrm{CO}_{2}$, a $37^{\circ} \mathrm{C}$.

- Sem Fusão: Células dendríticas cocultivadas com linfócitos T alogenêicos apenas em matriz $3 \mathrm{D}$ Biotek em estufa com $5 \%$ de $\mathrm{CO}_{2}$, a $37{ }^{\circ} \mathrm{C}$.

- Fusão Linhagem: Células dendríticas fundidas com células da linhagem de adenocarcinoma de mama humana SKBR-3 (células híbridas dendríticas-tumorais) foram cocultivadas com linfócitos $\mathrm{T}$ alogenêicos em matriz 3D Biotek tratada com colágeno tipo III $(0,4 \mu \mathrm{g} / \mu \mathrm{L})$ em estufa com $5 \%$ de $\mathrm{CO}_{2}$, a $37^{\circ} \mathrm{C}$.

- Fusão Tumoral: Células dendríticas fundidas com células tumorais de pacientes com câncer de mama (células híbridas dendríticas-tumorais) foram cocultivadas com linfócitos $\mathrm{T}$ do mesmo paciente com câncer de mama em matriz 3D Biotek tratada com colágeno tipo III $(0,4$ $\mu \mathrm{g} / \mu \mathrm{L})$ em estufa com $5 \%$ de $\mathrm{CO}_{2}$, a $37{ }^{\circ} \mathrm{C}$.

Para a cultura 3D foi utilizada a matriz 3D Biotek. Esta matriz é composta de um arcabouço feito de poliestireno com espessura de $600 \mu \mathrm{m}$, fibras com $150 \mu \mathrm{m}$ e poros de 200 $\mu \mathrm{m}$. Além disso, este arcabouço possui uma área de crescimento celular de $1,5 \mathrm{~cm}^{2}$ (Figura 4), enquanto em culturas convencionais $2 \mathrm{D}$ a mesma equivaleria a $0,32 \mathrm{~cm}^{2}$.

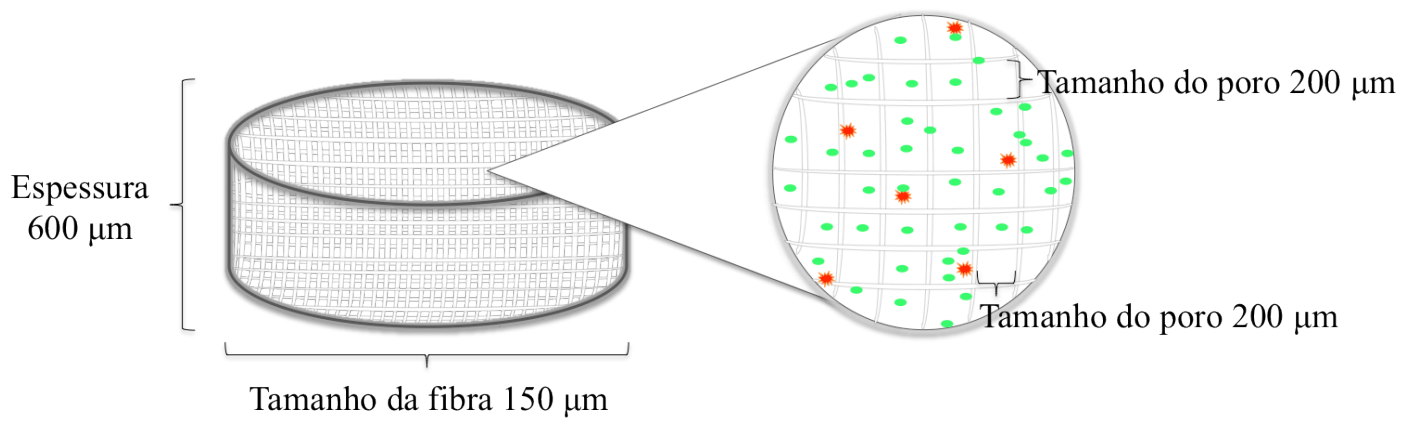

Figura 4 - Ilustração mostrando a estrutura 3D Biotek ${ }^{\mathrm{TM}}$. 
Para a realização da cocultura, após 7 dias em monocultura, 2,5 x $10^{4}$ de DCs coradas com CellTracker Red (vide item 3.9.3) em meio AIM-V foram colocadas no arcabouço juntamente com o colágeno do tipo III (grupo Col III) ou não (grupo Sem Col III) em $20 \mu \mathrm{L}$ e incubadas a $37^{\circ} \mathrm{C}$ por 3 horas. Após esse período, foram adicionados $180 \mu \mathrm{L}$ de meio de cultura AIM-V. Após 24 horas, $2,5 \times 10^{5}$ de linfócitos $\mathrm{T} \mathrm{CD} 3^{+} \mathrm{CD} 4^{+}$corados com CFSE (vide item 3.9.1) e linfócitos $\mathrm{T} \mathrm{CD}^{+} \mathrm{CD}^{+}$corados com CellTracker Orange (vide item 3.9.2) que foram recém transferidos para o meio de cultura AIM-V foram adicionados no ambiente 3D.

Células híbridas dendríticas-tumorais previamente marcadas com antt-CD11 e anttiHer-2/neu (vide item 3.10.3) em meio AIM-V foram colocadas no arcabouço juntamente com o colágeno do tipo III em $20 \mu \mathrm{L}$ e incubadas a $37^{\circ} \mathrm{C}$ por 3 horas. Após esse período, foram adicionados $180 \mu \mathrm{L}$ de meio de cultura AIM-V. Após 24 horas, $2,5 \times 10^{5}$ de linfócitos $\mathrm{T}$ $\mathrm{CD}^{+} \mathrm{CD}^{+}$CellTracker Orange (vide item 3.9.2) e linfócitos $\mathrm{T} \mathrm{CD}^{+} \mathrm{CD} 8^{+}$que foram recém transferidos para o meio de cultura AIM-V foram adicionados no ambiente 3D.

Logo após a adição dos linfócitos $\mathrm{T}_{\mathrm{CD}}{ }^{+} \mathrm{CD}^{+}$e linfócitos $\mathrm{T} \mathrm{CD}^{+} \mathrm{CD}^{+}$aos diferentes grupos contendo 0h-DCs, 2h-mDCs e 48h-mDCs ou células híbridas dendríticastumorais, os experimentos foram analisados em microscópio confocal Zeiss LSM 780 (Zeiss).

\subsection{Análise da duração das interações celulares e migração de DCs, células híbridas e linfócitos T em ambiente 3D}

A cinética da duração das interações celulares e a migração de linfócitos foram realizadas através do microscópio confocal LSM 780 com incubadora com temperatura controlada e injetor de gás carbônico. Imagens das células fluorescentes foram adquiridas a cada 20 minutos em um tempo total de 17 horas com objetiva de 40 vezes. Todas as imagens foram analisadas com o programa de análise Zen 2009 Light Edition (Zeiss).

Para determinação da motilidade, marcações manuais dos centros celulares foram realizadas. $\mathrm{O}$ caminho de uma célula individual foi definido como a sequência de pontos do centro da célula em diferentes tempos. Mensurações do trajeto de células individuais em diferentes intervalos de tempo foram analizadas utlizando o plug-in MTrackJ (desenvolvido por Erik Meijering, Biomedical Imaging Group Rotterdam, Erasmus MC University Medical Center Rotterdam, the Netherlands). Esse plug-in é um módulo do programa Image J (software de domínio público desenvolvido por Wayne Rasband, NIMH, NIH, USA, HTTP://rsbweb.nih.gov/ij/), e foi desenvolvido para facilitar o desenho manual dos trajetos de 
objetos em movimento em imagens seqüenciais, como também permitir mensurações das distâncias percorridas e as velocidades.

\subsection{Detecção de citocinas por ensaio de citometria por beads (CBA).}

Após 17 horas de cocultura, os sobrenadantes de $0 \mathrm{~h}-\mathrm{DCs}, 2 \mathrm{~h}-\mathrm{mDCs}$ e $48 \mathrm{~h}-\mathrm{mDCs}$ ou de culturas isoladas de células híbridas e linfócitos $\mathrm{T}$, foram avaliados por CBA (BD Biosciences) quanto a presença das citocinas IL-4, IL-6, IL-10, IL-17A, TNF- $\alpha$ IL-12 e Interferon- $\gamma($ IFN- $\gamma)$. Resumidamente, os sobrenadantes e os padrões de citocinas do kit foram incubados com microesferas de captura recobertas com anticorpos específicos para as respectivas citocinas e com o anticorpo de detecção marcado com ficoeritrina (PE). Após as incubações de 3 horas no escuro à temperatura ambiente, foi acrescido $1 \mathrm{~mL}$ da solução de lavagem e o material centrifugado por 5 minutos a $200 \mathrm{~g}$. O sobrenadante foi desprezado e o botão ressupendido em $300 \mu \mathrm{L}$ da solução de lavagem, por fim a detecção das citocinas foi realizada em citômetro de fluxo FACSCanto ${ }^{\mathrm{TM}}$ II. Os resultados analisados com auxílio do programa de análise BD FCAP Array versão 3.0.1 (BD Biosciences).

\subsection{Ensaio da proliferação de linfócitos $T$ cocultivados com células dendríticas ou células híbridas dendríticas-tumorais}

Os grupos Sem Col III, Col III, Fusão Linhagem e Fusão Tumoral foram submetidos ao ensaio de proliferação e para avaliar a capacidade estimuladora das células híbridas (ou DCs), também denominadas de células estimuladoras $\left(2,5 \times 10^{4}\right)$, foram cocultivadas com linfócitos $\mathrm{T}$, também denominados de células respondedoras $\left(2,5 \times 10^{5}\right)$, respeitando a proporção de 10 células respondedoras para 1 célula estimuladora. As células foram mantidas por 120 horas em estufa com atmosfera contendo $5 \%$ de $\mathrm{CO}_{2}$ a $37{ }^{\circ} \mathrm{C}$. Ao final da cultura, analisamos expressão de CD4, CD8 e CD25 presentes na membrana dos linfócitos e a diluição do corante CellTrace Violet (CTV; Molecular Probes ${ }^{\circledR}$ by Life Technologies ${ }^{\mathrm{TM}}$ ). Para tal, utilizamos citômetro de fluxo FACSCanto ${ }^{\mathrm{TM}}$ II, e o programa FlowJo versão 8.7 para posterior análise.

\subsubsection{Marcação de linfócitos com CellTrace Violet (CTV), anti-CD4, anti-CD8 e anti-CD25 e análise por Citometria de Fluxo}

Os linfócitos $\mathrm{T}$ foram corados com o corante vital fluorescente CellTrace Violet. Resumidamente, os linfócitos foram incubados no escuro com 2,5 $\mu \mathrm{M}$ do corante em PBS em 
constante agitação, a temperatura ambiente e por 20 minutos. Após esse período, as células foram incubadas por 5 minutos com R-10 e centrifugadas a $300 \mathrm{~g}$ por 10 minutos. Logo após, o sobrenadante foi retirado e as células novamente incubadas por 5 minutos com R-10 e centrifugadas a $300 \mathrm{~g}$ por 10 minutos. Por fim, o sobrenadante foi descartado e o precipitado ressuspenso em meio de cultura AIM-V para posterior ensaio de proliferação.

Já para a marcação com os anticorpos anti-CD4, anti-CD8 e anti-CD25 utilizados para a análise das subpopulações de linfócitos $\mathrm{T}$ em proliferação, foi realizado o mesmo procedimento na marcação do fenótipo de membrana descrito anteriormente (Item 3.6). Além disso, foi utilizado o corante LIVE/DEAD Red (Life Technologies ${ }^{\mathrm{TM}}$ ) para a análise de viabilidade celular. As células já marcadas com os anticorpos, após as duas lavagens, foram ressuspensas novamente em $200 \mu \mathrm{L}$ de tampão para citometria (PBS-BSA 0,5\%, 0,02\% de azida sódica sem paraformaldeído). Um total de 20000 eventos foram adquiridos/amostra. A descrição detalhada dos anticorpos é mostrada no Tabela 6.

Tabela 6 - Anticorpos monoclonais (BD Biosciences) utilizados para avaliação das subpopulações de linfócitos $\mathrm{T}$.

\begin{tabular}{|c|c|c|c|}
\hline Especificidade & Clone & Isótipo/Origem & Marcação \\
\hline CD4 & RPA-T4 & $\mathrm{IgG}_{1} \mathrm{k} /$ camundongo & FITC \\
\hline CD8 & $\mathrm{SK} 1$ & $\mathrm{IgG}_{1} \mathrm{k} /$ camundongo & PerCP \\
\hline CD25 & $\mathrm{M}-\mathrm{A} 251$ & $\mathrm{IgG}_{1} \mathrm{k} /$ camundongo & $\mathrm{APC}$ \\
\hline
\end{tabular}

\subsubsection{Avaliação da proliferação celular}

Como estratégia de análise da proliferação celular, inicialmente o ajuste da voltagem dos lasers e a compensação foram realizadas como descrito nas Figuras 1A e B. Após a compensação, foi gerado um gráfico mostrando a viabilidade celular como descrito na Figura 3D. Em seguida, delimitou-se uma gate de SSC por FSC característicos de linfócitos (Figura 5A). Para definição das células em divisão, a intensidade de fluorescência deveria encontrarse reduzida aproximadamente pela metade, em comparação as células que não se dividiram. Então, dentro da população de linfócitos, foi gerado um histograma mostrando apenas aqueles linfócitos que proliferaram (Figura 5B). Dentro dos linfócitos que proliferaram delimitaramse então dois gates: $\mathrm{CD}^{+}$e $\mathrm{CD} 8^{+}$(Figura 5C). Dentro de cada população $\mathrm{CD} 4^{+}$ou $\mathrm{CD} 8^{+}$foi possível analisar o marcador de ativação CD25 (Figura 5D). 

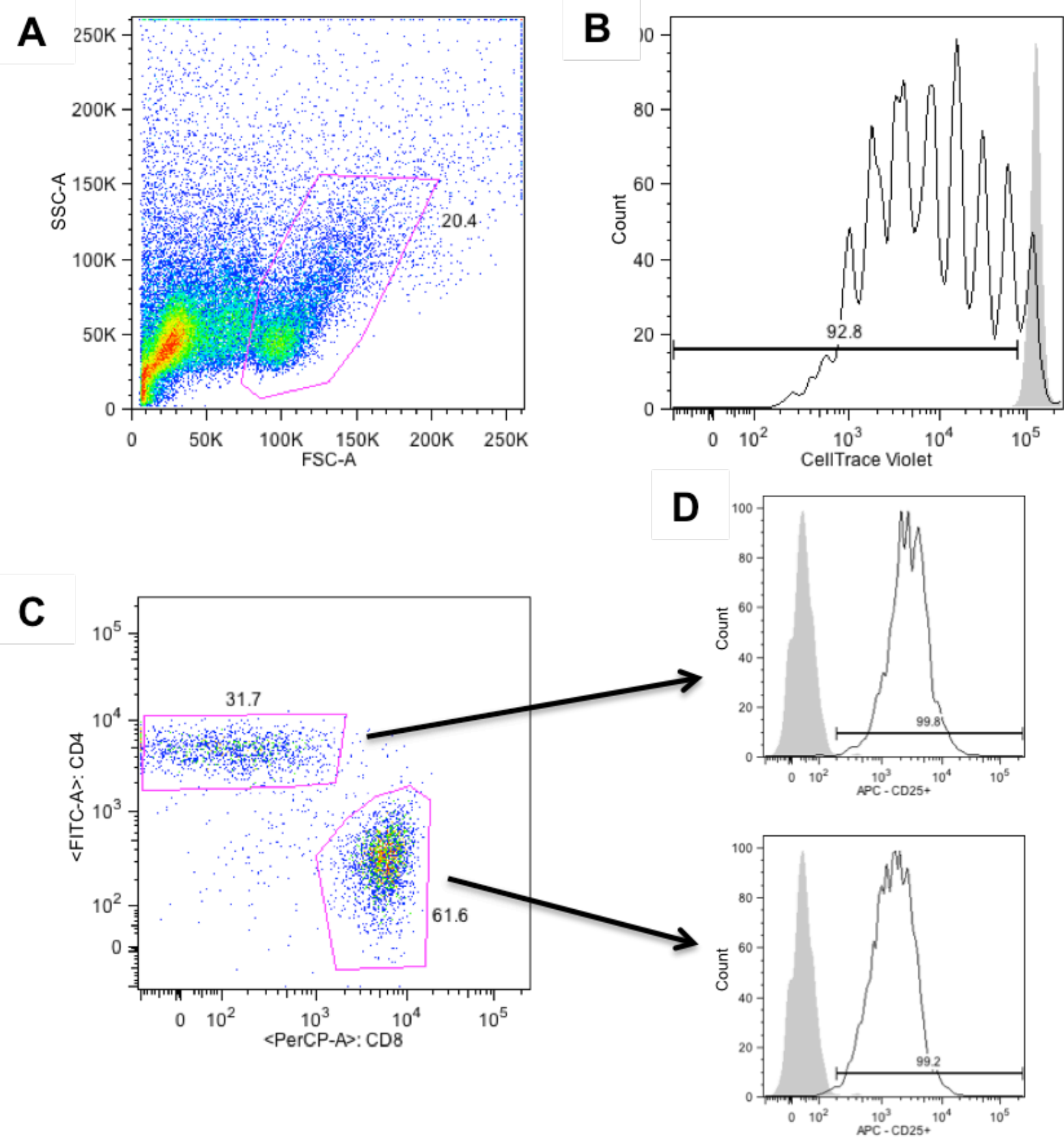

Figura 5 - Método de análise da proliferação celular. (A) Gráfico dot plot de SSC-A por FCS-A o qual representa a população com tamanho e granulosidade característicos de linfócitos; (B) Histograma mostrando linfócitos proliferando (diluição do CellTrace Violet); (C) Gráfico dot plot mostrando dois gates: $\mathrm{CD}^{+}$ (lado esquerdo) e $\mathrm{CD}^{+}$(lado direito); (D) Histogramas representativos das células positivas para CD25 dentro de linfócitos $\mathrm{T} \mathrm{CD} 4^{+}$(superior) e linfócitos $\mathrm{T}$ $\mathrm{CD}^{+}$(inferior); Nos histogramas as células não marcadas estão representadas em cinza e as marcadas, em preto. 


\subsection{Delineamento experimental dos cocultivos em ambiente 3D}

Com relação aos experimentos comparando os grupos Sem Col III vs Col III (Figura 6), no dia zero de cultura, células $\mathrm{CD}_{1} 4^{+}$(monócitos) separadas em coluna magnética de PBMCs de doadores saudáveis foram cultivadas em presença de IL-4 e GM-CSF por 7 dias, para geração de DCs imaturas (Grupo 0h-DCs) em placas de 24 poços. No quinto dia de cultura, parte dessas células foram ativadas por TNF- $\alpha$ (Grupo 48h-mDCs) e no sétimo dia de cultura as DCs foram coradas com CellTracker Red e transferidas para a matriz 3D tratada (Col III) ou não (Sem Col III) com colágeno do tipo III. No oitavo dia, um segundo grupo de células foi ativado apenas por 2 horas com TNF- $\alpha$ (Grupo 2h-mDCs). A análise da imunofenotipagem de $0 \mathrm{~h}-\mathrm{DCs}, 2 \mathrm{~h}-\mathrm{mDCs}$ e $48 \mathrm{~h}-\mathrm{mDC}$ foi feita por citometria de fluxo. Ainda no oitavo dia, os linfócitos $\mathrm{T}_{\mathrm{CD}}{ }^{+} \mathrm{CD} 4^{+}$e linfócitos $\mathrm{T} \mathrm{CD}^{+} \mathrm{CD}^{+}$alogenêicos (às $\mathrm{DCs}$ ) previamente descongelados, separados por coluna magnética foram corados com CFSE (linfócitos $\mathrm{T} \mathrm{CD}^{+} \mathrm{CD}^{+}$) e CellTracker Orange (linfócitos $\mathrm{T} \mathrm{CD}^{+} \mathrm{CD}^{+}$) e foram transferidos para a matriz 3D e iniciada a filmagem por 17 horas da cocultura por microspocia confocal. Após o períodos de 17 horas, no nono dia, o sobrenadante foi congelado para futuro ensaio de detecção de citocinas. Por fim, as 0h-DCs, $2 \mathrm{~h}-\mathrm{mDCs}$ e $48 \mathrm{~h}-\mathrm{mDCs}$ foram mantidas em cocultura com linfócitos $\mathrm{T} C D 3^{+} \mathrm{CD} 4^{+}$e linfócitos $\mathrm{T} \mathrm{CD} 3^{+} \mathrm{CD} 8^{+}$alogenêicos em ambiente 3D previamente tratado ou não com colágeno do tipo III, por 5 dias, após os quais, esses linfócitos foram marcados e analisados por citometria de fluxo. A Figura 6 sumariza todo o procedimento experimental adotado. 


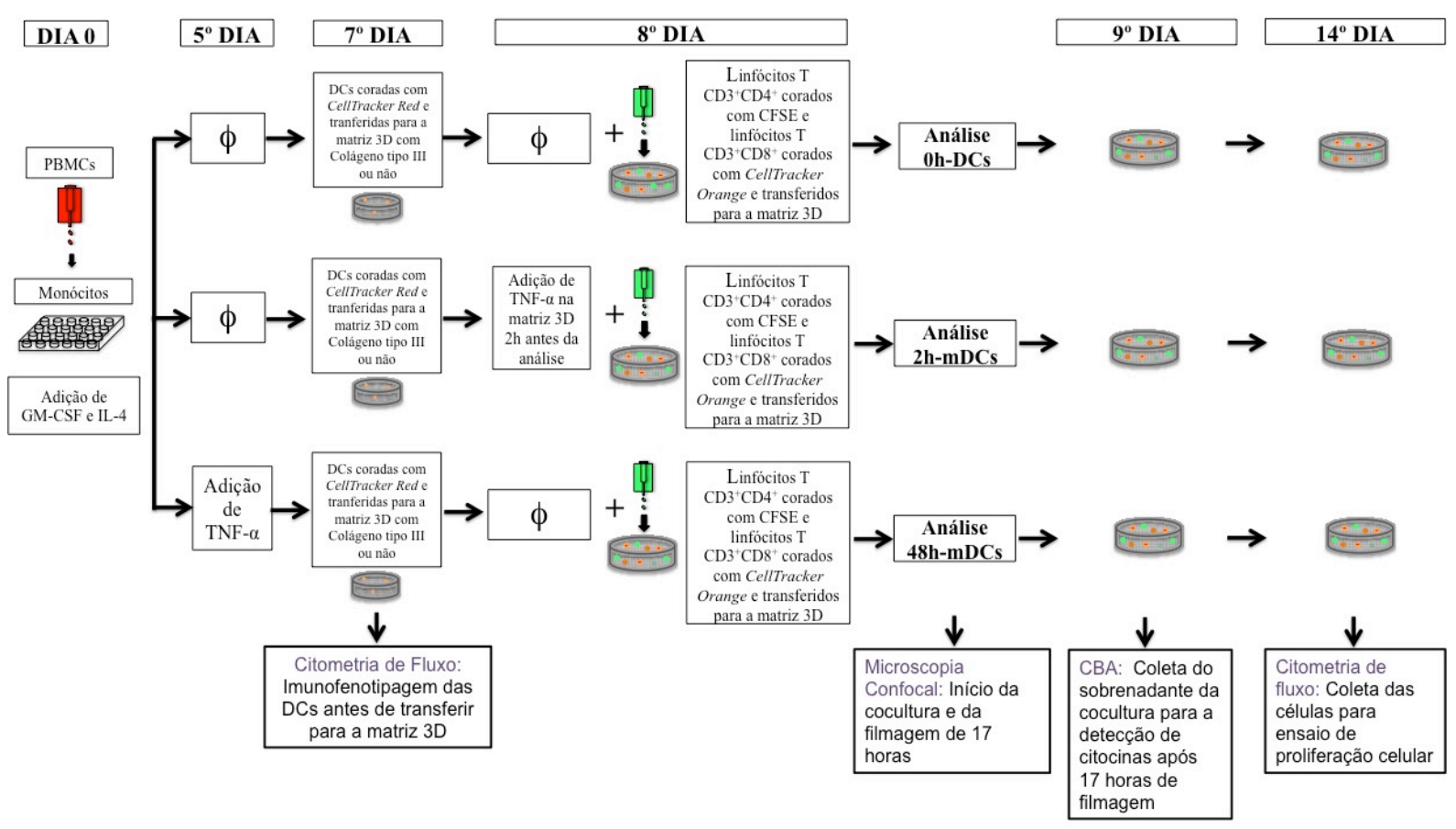

Figura 6 - Delineamento Experimental dos grupos Sem Col III vs Col III.

Com relação aos experimentos comparando os grupos Sem Fusão vs Fusão Linhagem vs Fusão Tumoral (Figura 7), no dia zero de cultura, células $\mathrm{CD}_{1} 4^{+}$(monócitos) separadas em coluna magnética de PBMCs de doadores saudáveis foram cultivadas em presença de IL-4 e GM-CSF por 7 dias. No quinto dia de cultura, todas as células foram ativadas por TNF- $\alpha$ (48h-mDCs). No sétimo dia de cultura as $48 \mathrm{~h}-\mathrm{mDC}$ foram marcadas com anti-CD11c e a linhagem de adenocarcimoma de mama SKBR-3 ou as células tumorais de pacientes foram marcadas com anti-Her-2/neu. Em seguida, 48h-mDCs e SKBR-3 foram fundidas gerando o grupo Fusão Linhagem e outra parte das $48 \mathrm{~h}-\mathrm{mDC}$ foram fundidas com células de pacientes com câncer de mama gerando o grupo Fusão Tumoral. Como controle usamos apenas 48hmDCs (Sem Fusão). As 48h-mDCs e as células híbridas dendríticas-tumorais foram passadas em nova coluna magnética anti-CD11c, irradiadas e transferidas para a matriz 3D tratada com colágeno do tipo III. No oitavo dia, os linfócitos $\mathrm{T}$ foram descongelados e separados por coluna magnética em linfócitos $\mathrm{T} \mathrm{CD}^{+} \mathrm{CD}^{+}$e linfócitos $\mathrm{T} \mathrm{CD}^{+} \mathrm{CD} 8^{+}$. Em seguida, linfócitos $\mathrm{T} \mathrm{CD} 3^{+} \mathrm{CD} 4^{+}$foram corados com CellTracker Orange e linfócitos $\mathrm{T} \mathrm{CD} 3^{+} \mathrm{CD} 8^{+}$não foram corados. Os linfócitos $\mathrm{T}$ foram transferidos para a matriz 3D onde já havia a presença das $48 \mathrm{~h}-\mathrm{mDCs}$ ou das células híbridas dendríticas-tumorais e foi iniciada a filmagem (que durou 17 horas) da cocultura por microspocia confocal. Ressalte-se que todos os linfócitos $\mathrm{T}$ são alogenêicos às DCs e no grupo Fusão Tumoral alogêneicos em relação as DCs mas 
autólogos em relação às células tumorais. Após o período de 17 horas, no nono dia de cultura, o sobrenadante foi congelado para futuro ensaio de detecção de citocinas. Por fim, 48h-mDCs e as células híbridas dendríticas-tumorais foram mantidas em cocultura com linfócitos $\mathrm{T}$ $\mathrm{CD}^{+}{ }^{\mathrm{CD}} 4^{+}$e linfócitos $\mathrm{T} \mathrm{CD} 3^{+} \mathrm{CD}^{+}$em ambiente 3D previamente tratado com colágeno do tipo III, por 5 dias, após os quais, esses linfócitos foram marcados e analisados por citometria de fluxo. A Figura 7 sumariza todo o procedimento experimental adotado.

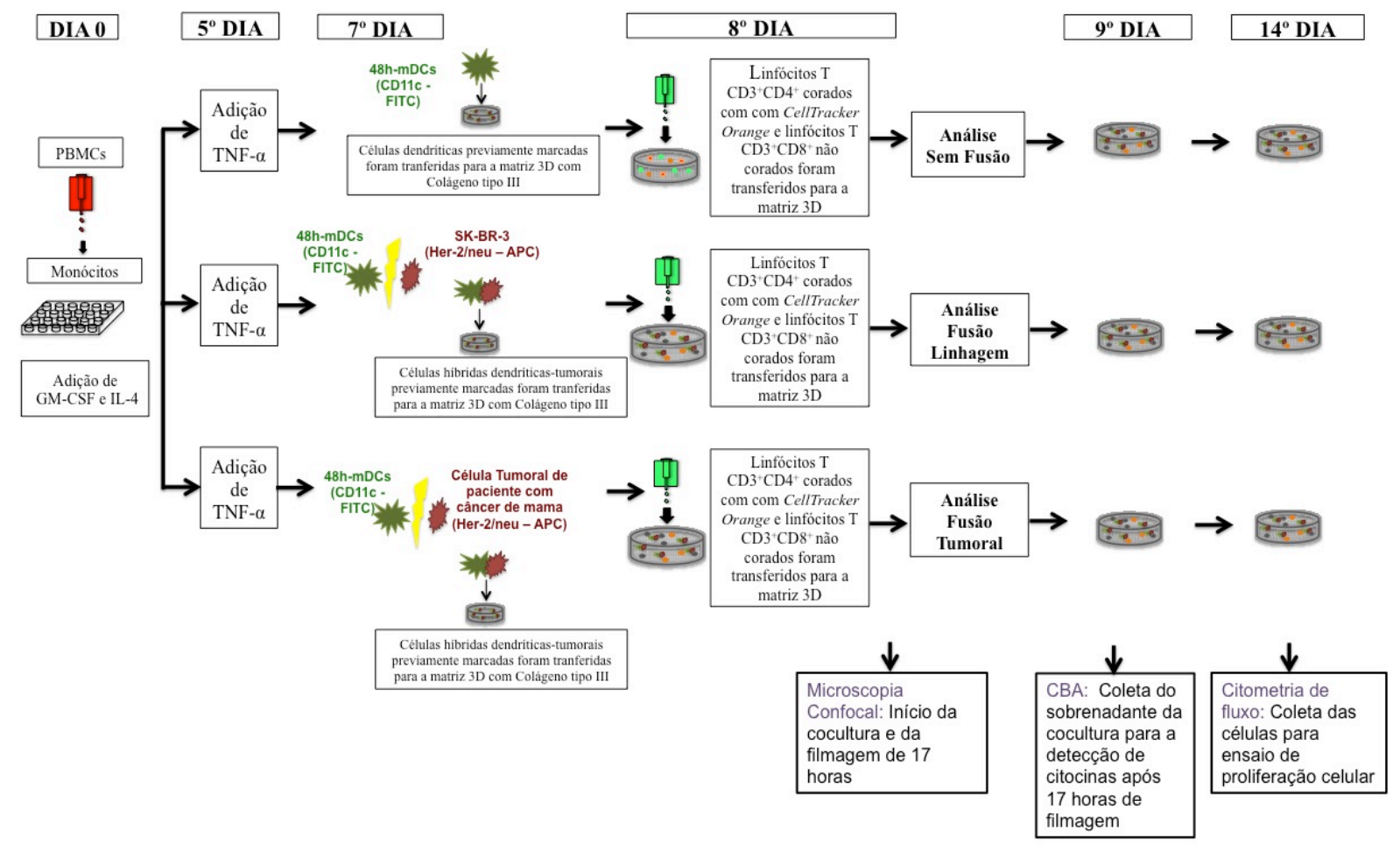

Figura 7 - Delineamento Experimental dos grupos Sem Fusão vs Fusão Linhagem vs Fusão Tumoral. 


\subsection{Análise estatística}

Para avaliação do fenótipo de membrana (monócitos, 0h-DCs, 2h-mDCs e 48h-mDCs), pureza das populações (monócitos, linfócitos $\mathrm{T} \mathrm{CD}^{+}$, linfócitos $\mathrm{T} \mathrm{CD}^{+}{ }^{+} \mathrm{CD} 4^{+}$e linfócitos $\mathrm{T}$ $\mathrm{CD}^{+} \mathrm{CD}^{+}$), porcentagens das interações celulares, tempo de interações, padrão de migração celular, padrão de citocinas e proliferação celular nos experimentos comparando os grupos Sem Col III vs Col III foi realizado através do teste One-way ANOVA seguido do teste de Tukey para comparações múltiplas.

Para avaliação das porcentagens das interações celulares, tempo de interações, padrão de migração celular e o padrão de citocinas nos experimentos com os grupos Sem Fusão vs Fusão Linhagem vs Fusão Tumoral foram realizados através do teste Two-way ANOVA seguido do teste de Bonferroni para comparações múltiplas. Para avaliação do ensaio de proliferação celular comparando os grupos Sem Fusão vs Fusão Tumoral foram realizados testes comparativos múltiplos de Student-Newman-Keuls.

Considerou-se uma diferença como tendo significância estatística quando apresentou $\mathrm{p}<0,05$. Todos os testes foram realizados com o auxílio do programa Graphpad Prisma 5 (GraphPad Software, EUA). 
4 RESULTADOS

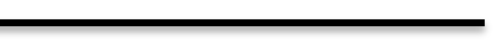




\section{RESULTADOS}

\subsection{Pureza de monócitos, linfócitos $\mathrm{T} \mathrm{CD3}^{+}$, linfócitos $\mathrm{T} \mathrm{CD3}^{+} \mathrm{CD4}^{+}$e linfócitos $\mathrm{T}$ $\mathrm{CD3}^{+} \mathrm{CD8}^{+}$}

A fim de confirmar a pureza das populações selecionadas para os estudos em ambiente 3D, foram realizados ensaios de citometria de fluxo após a separação das mesmas. Os monócitos foram separados por seleção negativa em coluna imunomagnética e apresentaram pureza compatível com o esperado após enriquecimento, visualizada através da expressão de CD14, com ausência das populações $\mathrm{CD}^{+}, \mathrm{CD}_{1} 9^{+}$e $\mathrm{CD}^{+} 6^{+}$(Figuras 8A e B).

$\mathbf{A}$

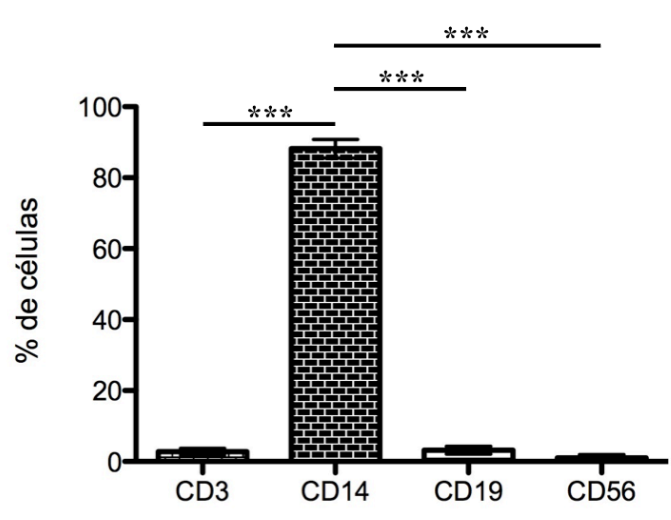

B
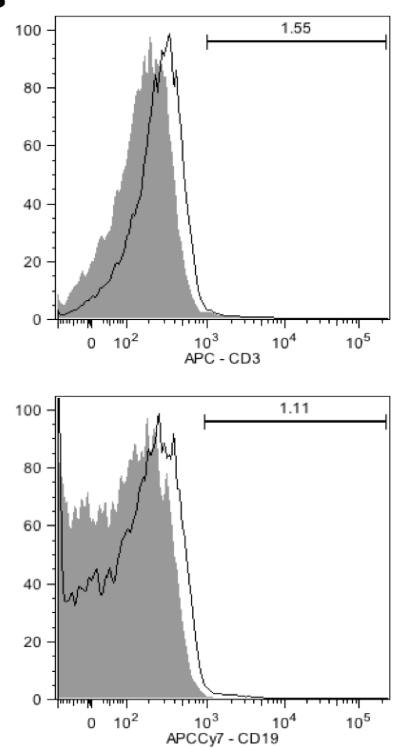
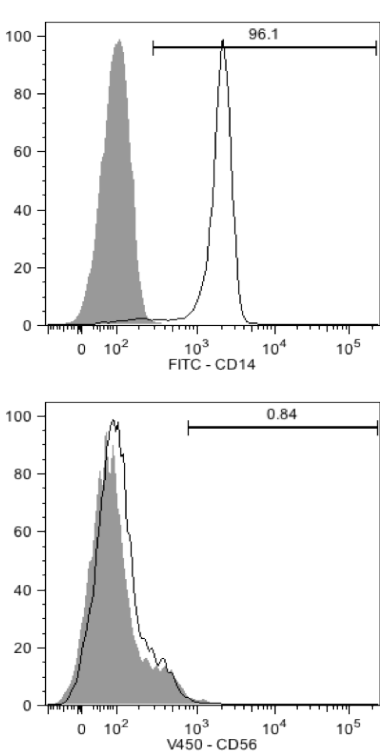

Figura 8 - Enriquecimento de monócitos do sangue periférico após seleção negativa por esferas imunomagnéticas. (A) Porcentagem de células expressando CD3, CD14, CD19 e CD56 dentro da população de monócitos purificados após o processo de seleção. Barras indicam o erro padrão; (***) indica $p<0,0001 ;(n=7)$. (B) Histogramas representativos da expressão das moléculas de superfície CD3, CD14, CD19 e CD56 na população selecionada; as células não marcadas estão representadas em cinza e as marcadas, em preto. 
Os Linfócitos $\mathrm{T} \mathrm{CD}^{+}$também foram selecionados negativamente em coluna imunomagnética. Aproximadamente $90 \%$ da população enriquecida apresentou expressão de CD3, com células $\mathrm{CD}^{+}$e $^{\mathrm{CD}} 8^{+}$na proporção de 3:1 (Figuras 9A e B).
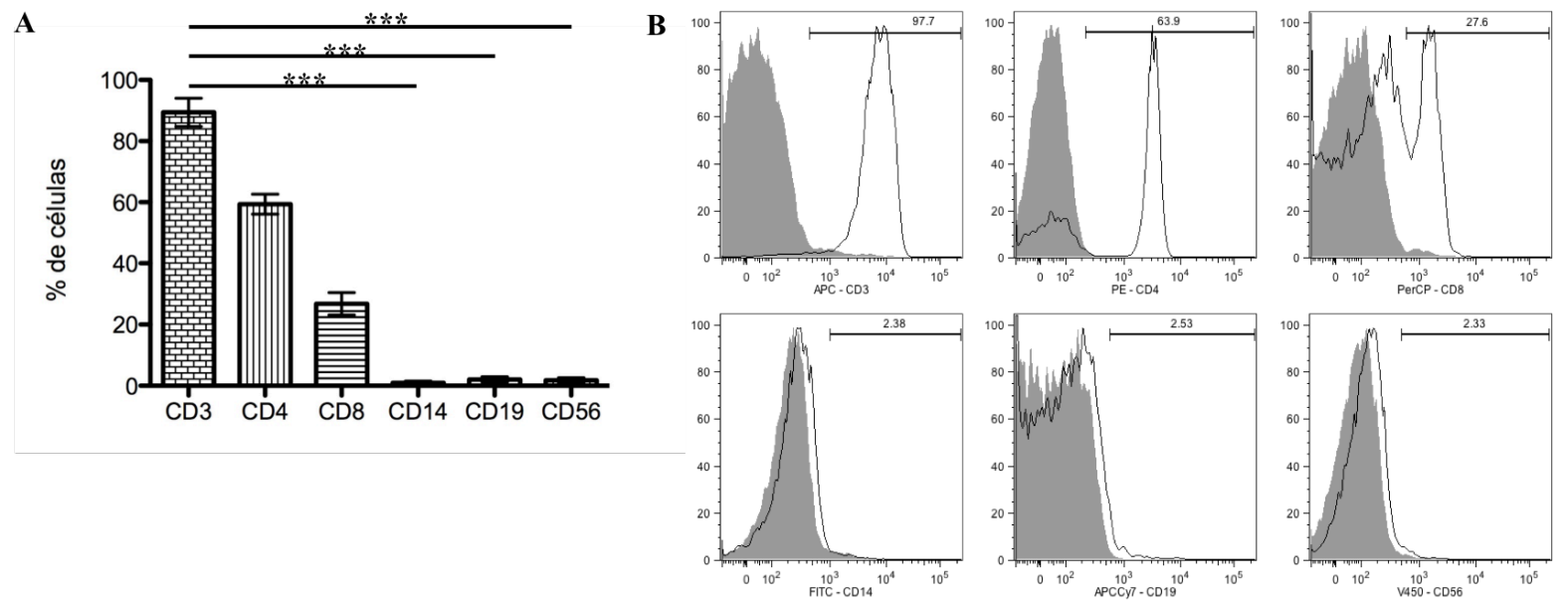

Figura 9 - Enriquecimento de linfócitos $\mathrm{T}^{\mathrm{CD3}^{+}}$do sangue periférico após seleção negativa por esferas imunomagnéticas. (A) Porcentagem de células expressando CD3, CD4, CD8, CD14, CD19 e CD56 dentro da população de linfócitos $\mathrm{T} \mathrm{CD}^{+}$purificados após o processo de seleção. Barras indicam o erro padrão; (***) indica $\mathrm{p}<0,0001 ;(\mathrm{n}=7)$. (B) Histogramas representativos da expressão das moléculas de superfície CD3, CD4, CD8, CD14, CD19 e CD56 na população selecionada; as células não marcadas estão representadas em cinza e as marcadas, em preto.

A separação de linfócitos $\mathrm{T} \mathrm{CD}^{+}$, foi realizada por seleção positiva em coluna imunomagnética a partir das células $\mathrm{CD}^{+}$e, para a obtenção de linfócitos $\mathrm{T} C \mathrm{CD} 8^{+}$, as células que passaram livremente pela coluna após a marcação com o anti-CD4 foram novamente passadas em nova coluna para a retirada da contaminação de outros linfócitos. Para linfócitos T CD4 ${ }^{+}$, obtivemos uma pureza de 95\% (Figuras 10A e B). No entanto, a população de linfócitos $\mathrm{T} \mathrm{CD}^{+}$apresentou pureza menor, provavelmente porque essas células podem ter sofrido mais no processo de separação por coluna, visto que foram necessárias três passagens em colunas diferentes para sua separação (Figuras 11A e B). Embora a pureza desta população tenha ficado abaixo dos $90 \%$ encontrados nas populações anteriores, conseguiu-se um enriquecimento relativo muito significativo. 

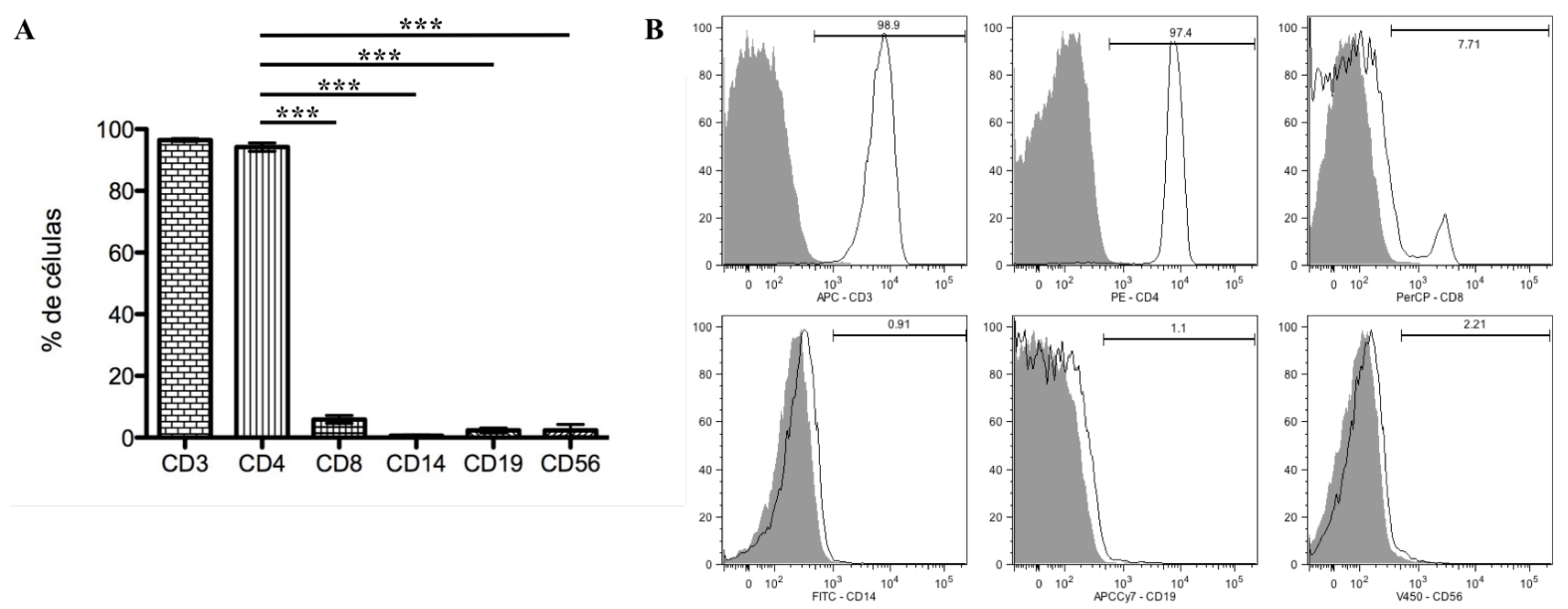

Figura 10 - Enriquecimento de linfócitos $\mathrm{T} \mathrm{CD4}^{+}$do sangue periférico após seleção positiva por esferas imunomagnéticas. (A) Porcentagem de células expressando CD3, CD4, CD8, CD14, CD19 e CD56 dentro da população de linfócitos $\mathrm{T} \mathrm{CD}^{+}$purificados após o processo de seleção. Barras indicam o erro padrão; $(* * *)$ indica $\mathrm{p}<0,0001$; $(\mathrm{n}=7)$. (B) Histogramas representativos da expressão das moléculas de superfície CD3, CD4, CD8, CD14, CD19 e CD56 na população selecionada; as células não marcadas estão representadas em cinza e as marcadas, em preto.
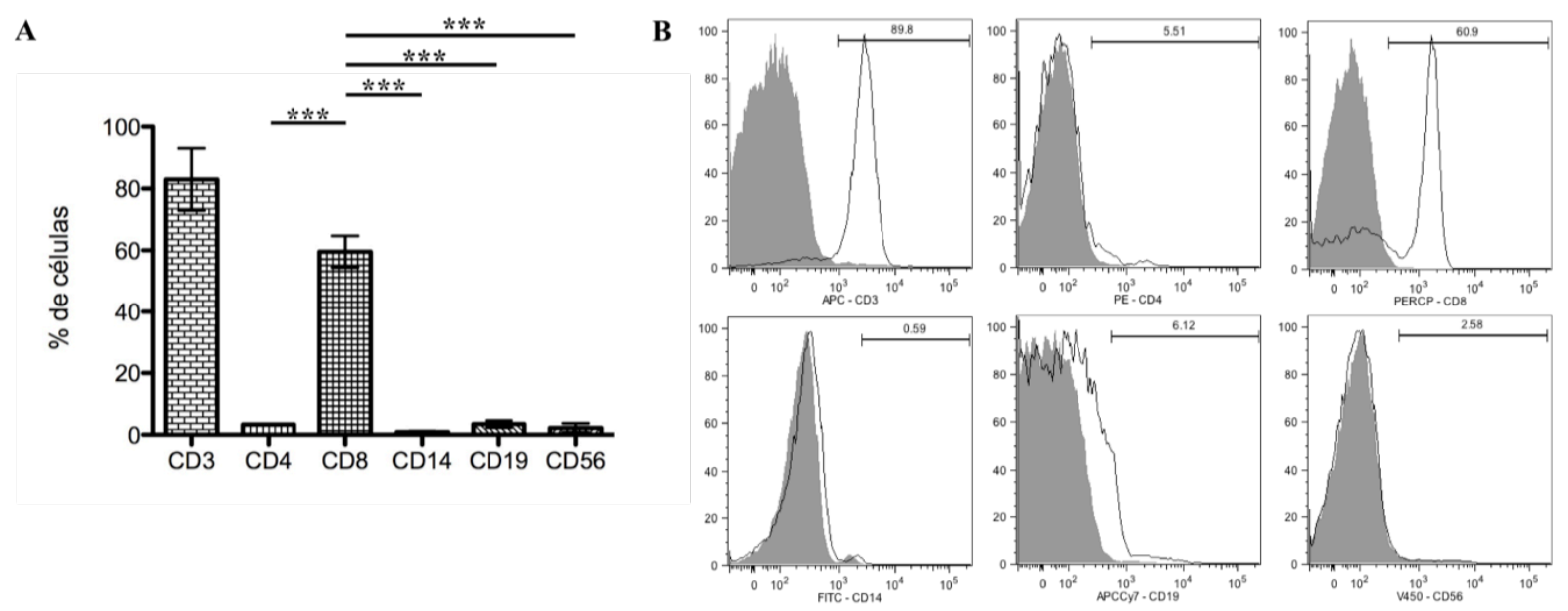

Figura 11 - Enriquecimento de linfócitos $\mathrm{T} \mathrm{CD8}^{+}$do sangue periférico após seleção negativa por esferas imunomagnéticas. (A) Porcentagem de células expressando CD3, CD4, CD8, CD14, CD19 e CD56 dentro da população de linfócitos $\mathrm{T} \mathrm{CD}^{+}$purificados após o processo de seleção. Barras indicam o erro padrão; $(* * *)$ indica $\mathrm{p}<0,0001 ;(\mathrm{n}=7)$. (B) Histogramas representativos da expressão das moléculas de superfície CD3, CD4, CD8, CD14, CD19 e CD56 na população selecionada; as células não marcadas estão representadas em cinza e as marcadas, em preto. 


\subsection{Características morfológicas de monócitos, 0h-DCs, $2 \mathrm{~h}-\mathrm{mDCs}$ e $48 \mathrm{~h}-\mathrm{mDCs}$}

Através de análise morfológica por microscopia de luz convencional, observamos que as células $\mathrm{CD}_{1} 4^{+}$possuem morfologia característica de monócitos, pequenas células (em comparação às DCs) arredondadas e aderidas ao plástico (Figura 12A). No sétimo dia da cultura, as células que apenas receberam o tratamento com as citocinas IL-4 e GM-CSF, consideradas 0h-DCs, apresentaram-se mais alongadas aparentando maior superfície celular e aderência à placa (Figura 12B). No sétimo dia de cultura, parte das células receberam o estimulo de maturação e diferenciação com TNF- $\alpha$ por 2 horas. Parte dessas células apresentaram uma forma arredondada enquanto a outra parte apresentou-se mais alongada (Figura 12C). Já as células ativadas por 48 horas com TNF- $\alpha$ apresentaram um aumento de tamanho, bem como um aumento no número de células arredondadas e com prolongamentos citoplasmáticos, além de ser possível observar diversas células não-aderidas à placa (Figura 12D). 


\section{Resultados 61}

A

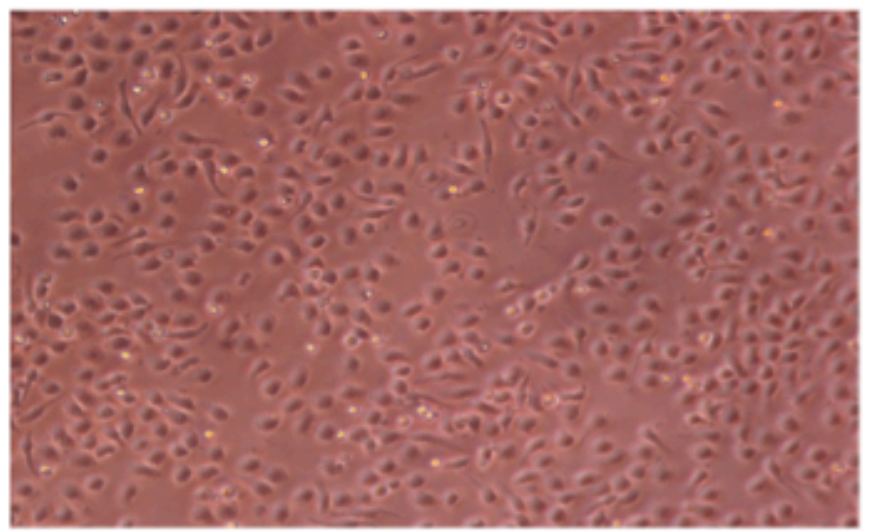

B

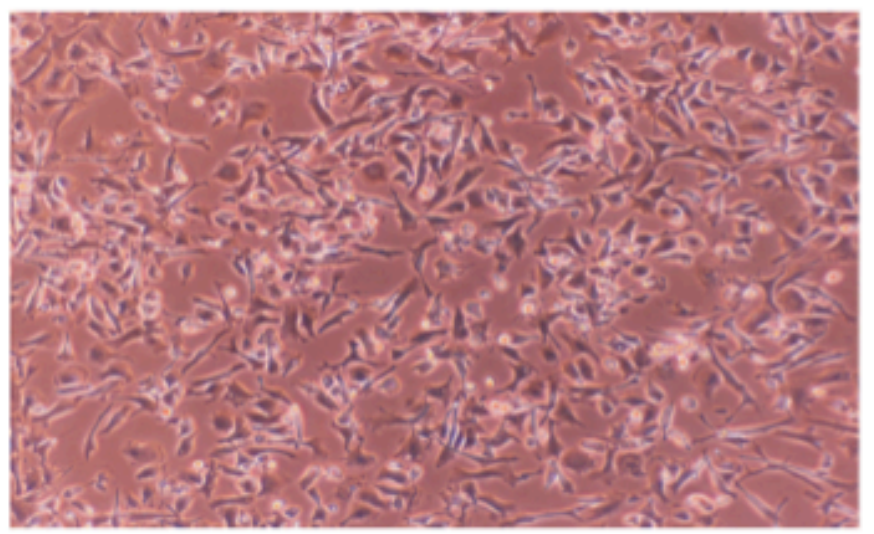

c

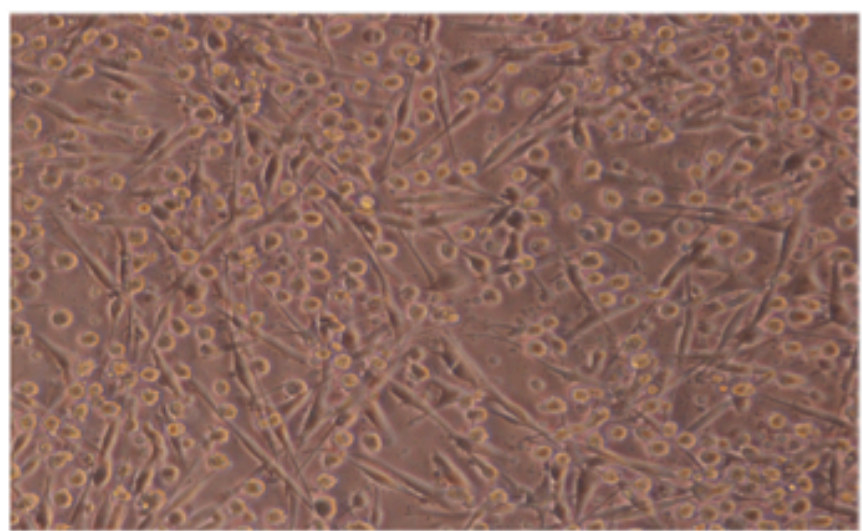

D

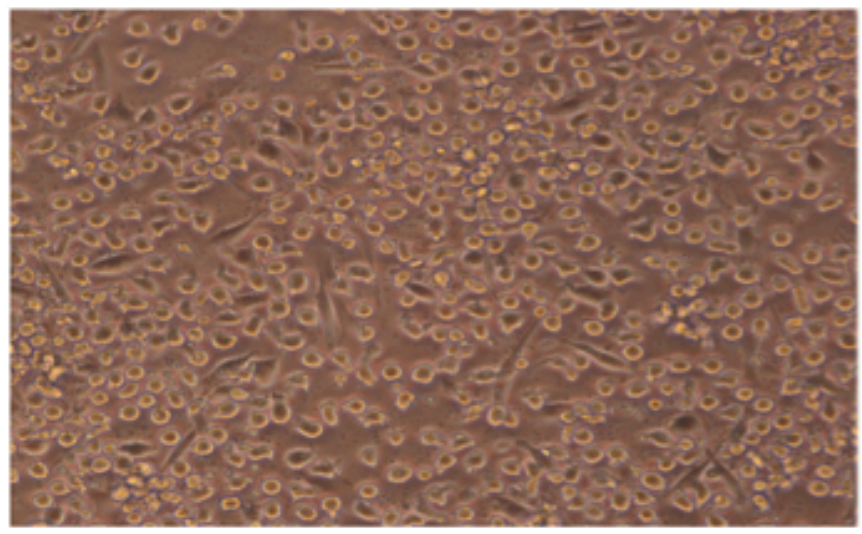

Figura 12 - Fotomicrografias de culturas para diferenciação em DCs. (A) monócitos; (B) DCs imaturas (0h-DCs); (C) DCs ativadas por 2 horas com TNF- $\alpha$ (2h-mDCs); (D) DCs ativadas por 48 horas com TNF- $\alpha$ (48h-mDCs). Aumento de 200x. 


\subsection{Caracterização imunofenotípica de monócitos, 0h-DCs, $2 \mathrm{~h}$-mDCs e 48h-mDCs}

As células consideradas monócitos, 0h-DCs, 2h-mDCs e 48h-mDCs foram analisadas fenotipicamente por citometria de fluxo. Todos os grupos foram marcados para CD1a, CD11c, CD14, CD40, CD80, CD83, CD86, CD209, CCR7, HLA-DR e PD-L1.

Monócitos e DCs derivadas de monócitos apresentam como características fenotípicas a expressão de um marcador de origem mielóide, o CD11c; e de uma molécula apresentadora de antígeno, o HLA-DR (SALLUSTO; LANZAVECCHIA, 1994). De fato, os monócitos expressam em quase sua totalidade as moléculas CD11c e HLA-DR (Figura 13A e B). Já dentre as células com tamanho e granulosidade de DCs, a porcentagem de células

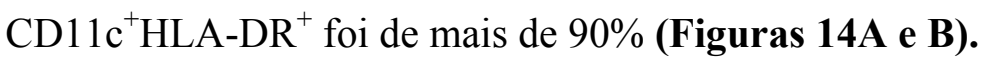

A

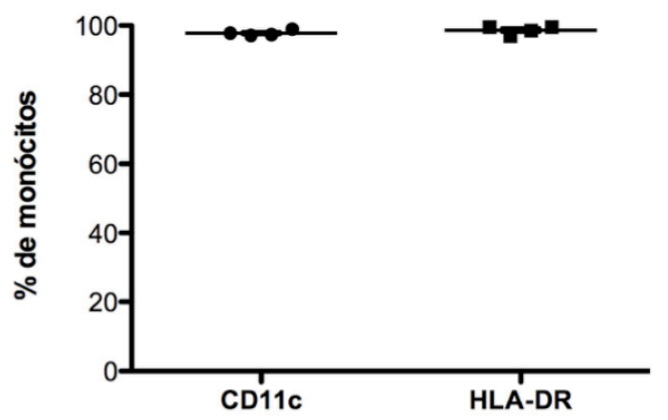

C

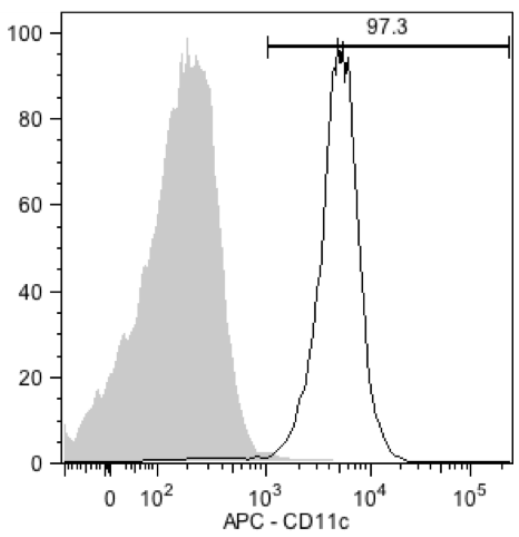

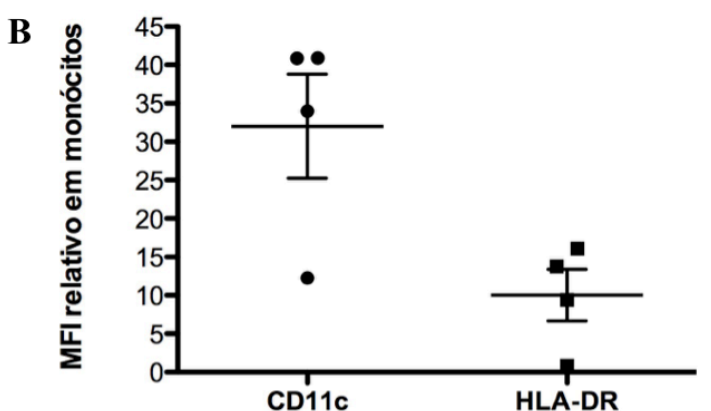

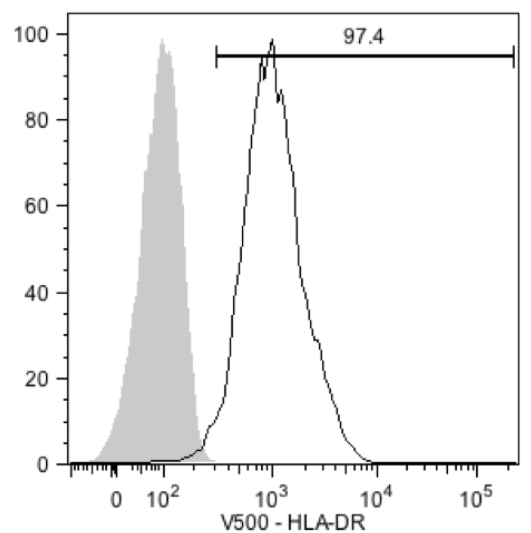

Figura 13 - Expressão de CD11c ${ }^{+}$e HLA-DR ${ }^{+}$em monócitos. (A) Porcentagem de células CD11 $\mathrm{c}^{+}$e HLA-DR ${ }^{+}$em monócitos (calculada dentro da população de células vivas). Barras indicam o erro padrão; $n=4$. (B) MFI relativa de CD11 c ${ }^{+}$e HLA$\mathrm{DR}^{+}$, calculada dividindo-se o valor da MFI da população positiva para CD11c e HLA-DR pelo valor da MFI do seu respectivo tubo sem marcação. C) Histogramas representativos da expressão da molécula de superfície CD11c (esquerda) e HLA-DR (direita); as células não marcadas estão representadas em cinza e as marcadas, em preto. 


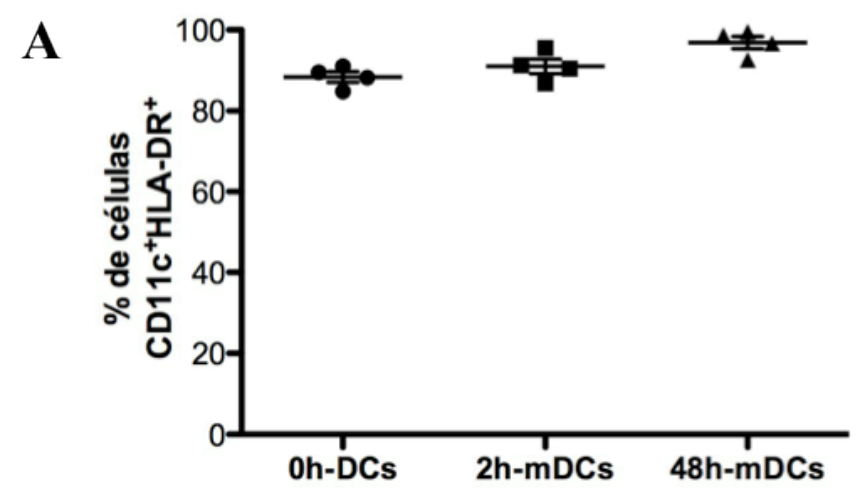

B

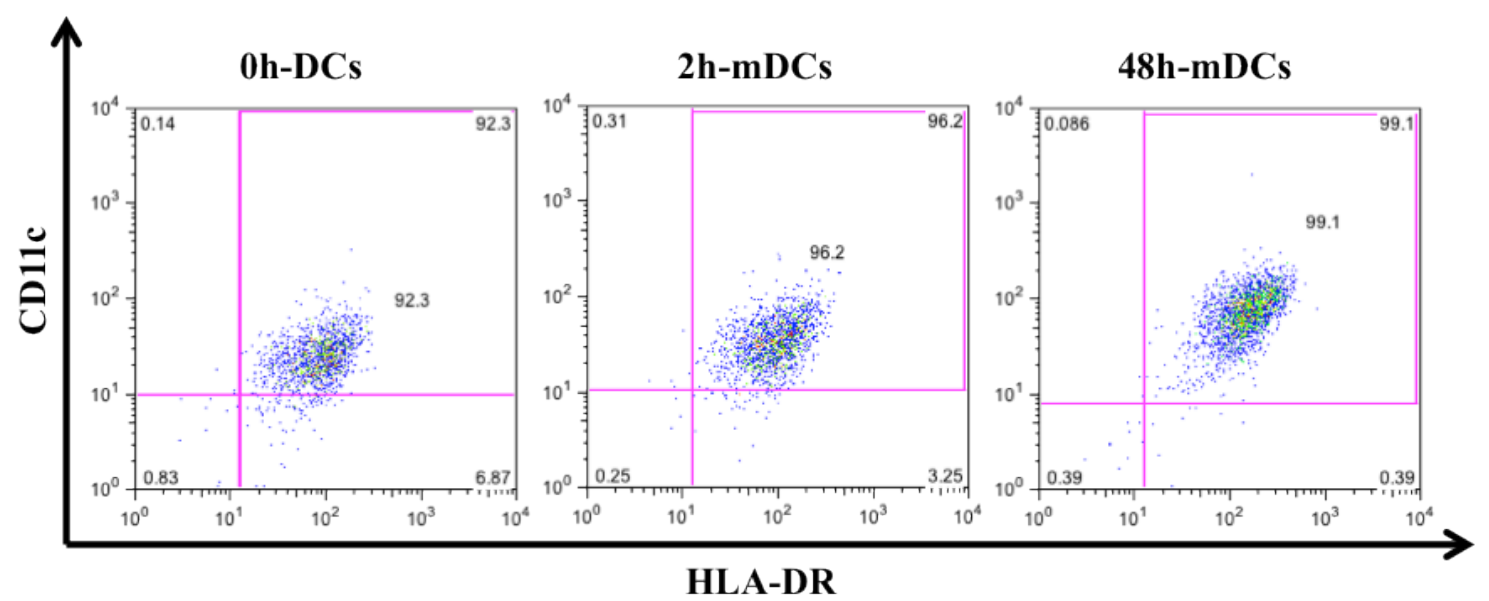

Figura 14 - Expressão de CD11c ${ }^{+} \mathrm{HLA}_{-D R^{+}}$em 0h-DCs, 2h-mDCs e 48h-mDCs. (A) Porcentagem de células CD11 ${ }^{+} \mathrm{HLA}^{-D R^{+}}$em 0h-DCs, 2h-mDCs e 48h-mDCs. Barras indicam o erro padrão; $\mathrm{p}>0,05 ; \mathrm{n}=4$. (B) Gráficos dot plot representativos da expressão das moléculas de superfície CD11 $\mathrm{c}^{+} \mathrm{HLA}^{-D R^{+}}$. 
Na população celular CD11 c ${ }^{+} \mathrm{HLA}_{-} \mathrm{DR}^{+}$, analisou-se a expressão de CD14, conhecido marcador de monócitos. Como esperado, a porcentagem de células $\mathrm{CD}_{1}{ }^{+}$diminuiu gradativamente e significantemente à medida que os monócitos se diferenciaram em 0h-DCs, 2h-mDCs e 48h-mDCs (Figuras 15A e B).

A

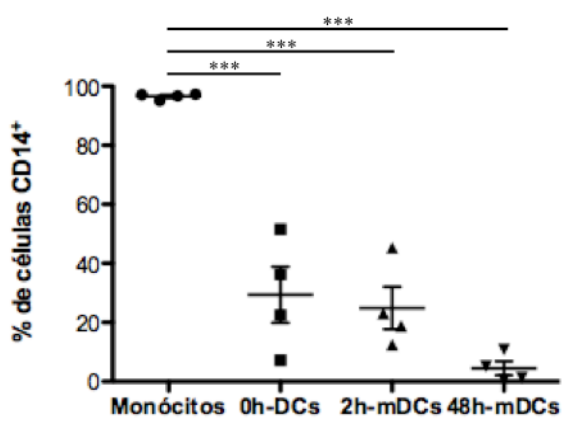

B

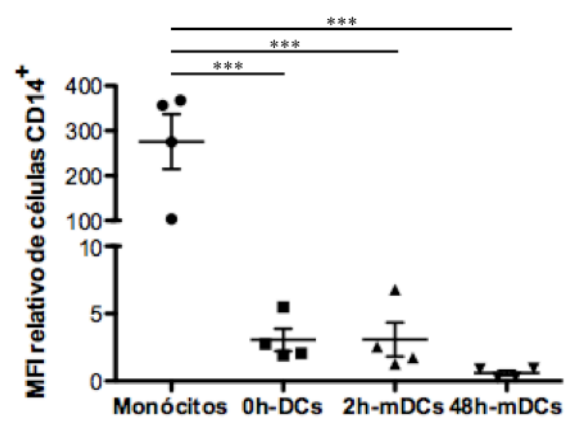

C

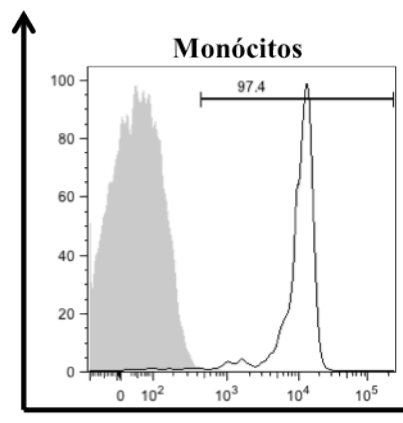

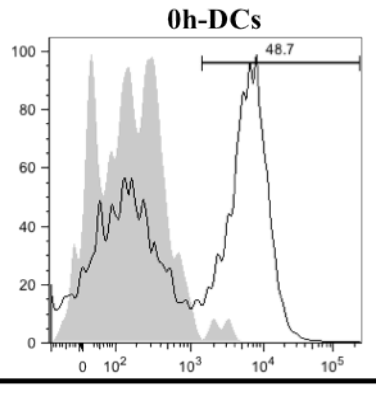

CD14
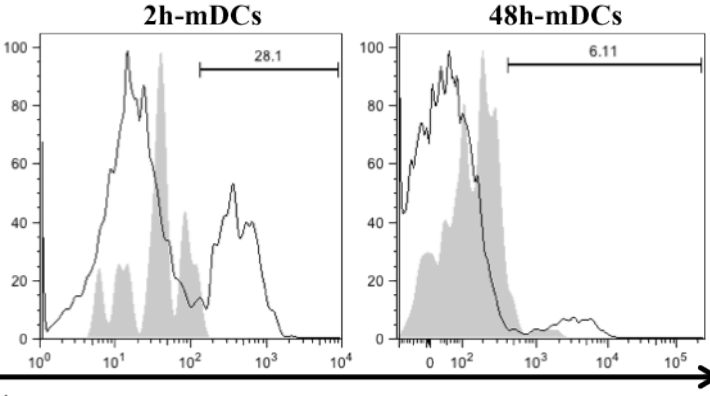

Figura 15 - Expressão de CD14 ${ }^{+}$em monócitos, 0h-DCs, 2h-mDCs e 48h-mDCs. (A) Porcentagem de células $\mathrm{CD}_{1} 4^{+}$em monócitos (calculada dentro da população de células vivas), 0h-DCs, $2 \mathrm{~h}-\mathrm{mDCs}$ e $48 \mathrm{~h}-\mathrm{mDCs}$ (dentro da população CD11 $\mathrm{c}^{+}$HLA-DR ${ }^{+}$. Barras indicam o erro padrão; $(* * *)$ indica $\mathrm{p}<0,0001 ; \mathrm{n}=4$. (B) MFI relativa de CD14, calculada dividindo-se o valor da MFI da população positiva para CD14 pelo valor da MFI do tubo sem marcação. (C) Histogramas representativos da expressão da molécula de superfície CD14; as células não marcadas estão representadas em cinza e as marcadas, em preto. 
As moléculas coestimuladoras de linfócitos T CD40, CD80 e CD86 também foram analisadas. A molécula de superfície $\mathrm{CD}_{4} 0^{+}$apresentou uma baixa expressão em monócitos, quando comparados aos demais grupos de DCs (Figura 16A), mas não houve diferenças significativas quando o MFI foi analisado (Figura 16B).

A

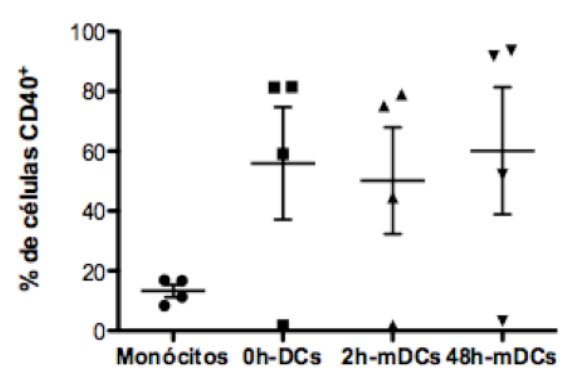

B

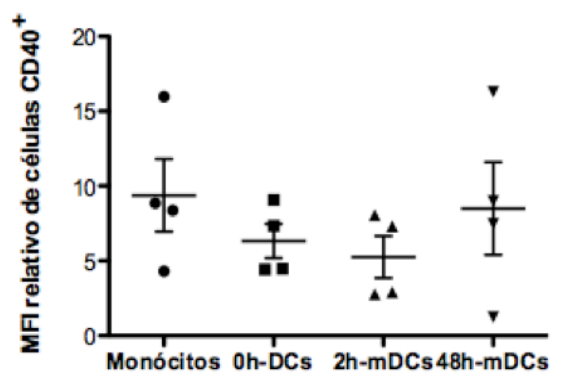

C
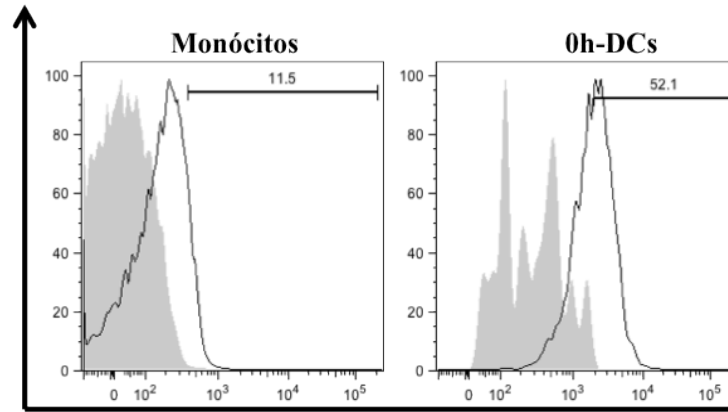

2h-mDCs

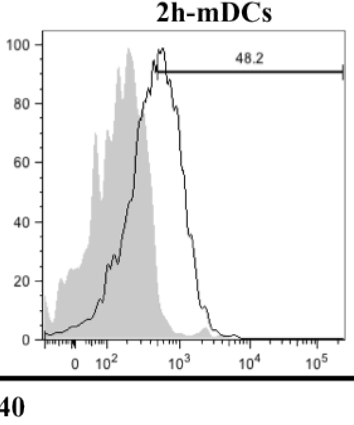

48h-mDCs

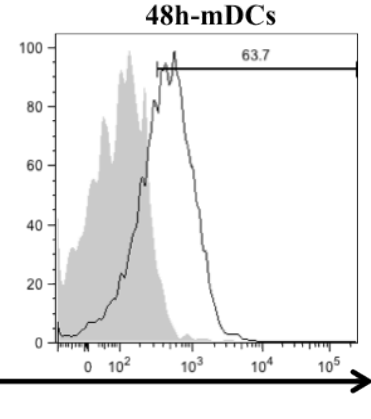

Figura 16 - Expressão de CD40 ${ }^{+}$em monócitos, 0h-DCs, 2h-mDCs e 48h-mDCs. (A) Porcentagem de células $\mathrm{CD}^{+} 0^{+}$em monócitos (calculada dentro da população de células vivas), $0 \mathrm{~h}-\mathrm{DCs}, 2 \mathrm{~h}-\mathrm{mDCs}$ e $48 \mathrm{~h}-\mathrm{mDCs}$ (dentro da população CD11 ${ }^{+}$HLA-DR $^{+}$). Barras indicam o erro padrão; $p>0,05 ; n=4$. (B) MFI relativa de CD40, calculada dividindo-se o valor da MFI da população positiva para CD40 pelo valor da MFI do tubo sem marcação. (C) Histogramas representativos da expressão da molécula de superfície CD40; as células não marcadas estão representadas em cinza e as marcadas, em preto. 
No que se diz respeito à molécula CD80, houve um aumento significante de sua expressão quando comparamos o grupo 48h-mDCs com os outros grupos, tanto em porcentagem de células positivas quanto em MFI relativa (Figuras 17A e B).

A

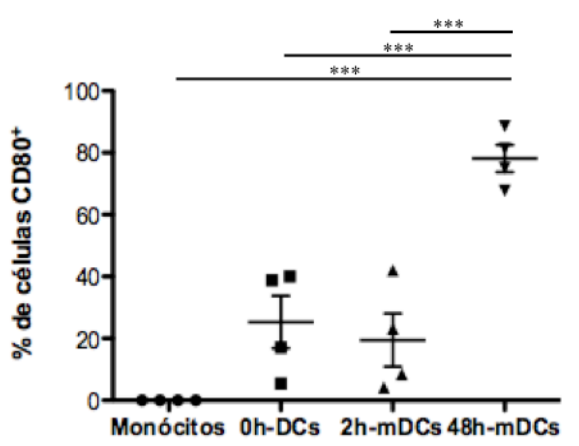

B

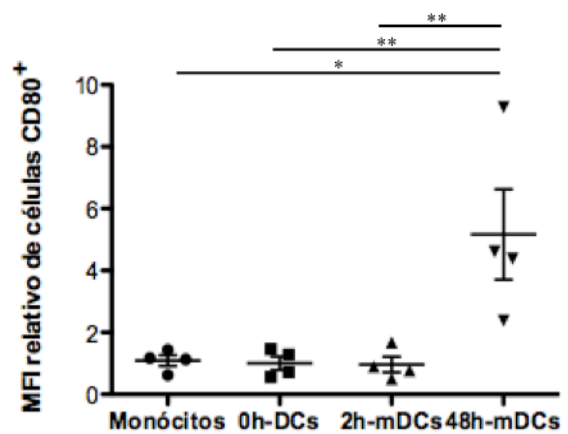

C
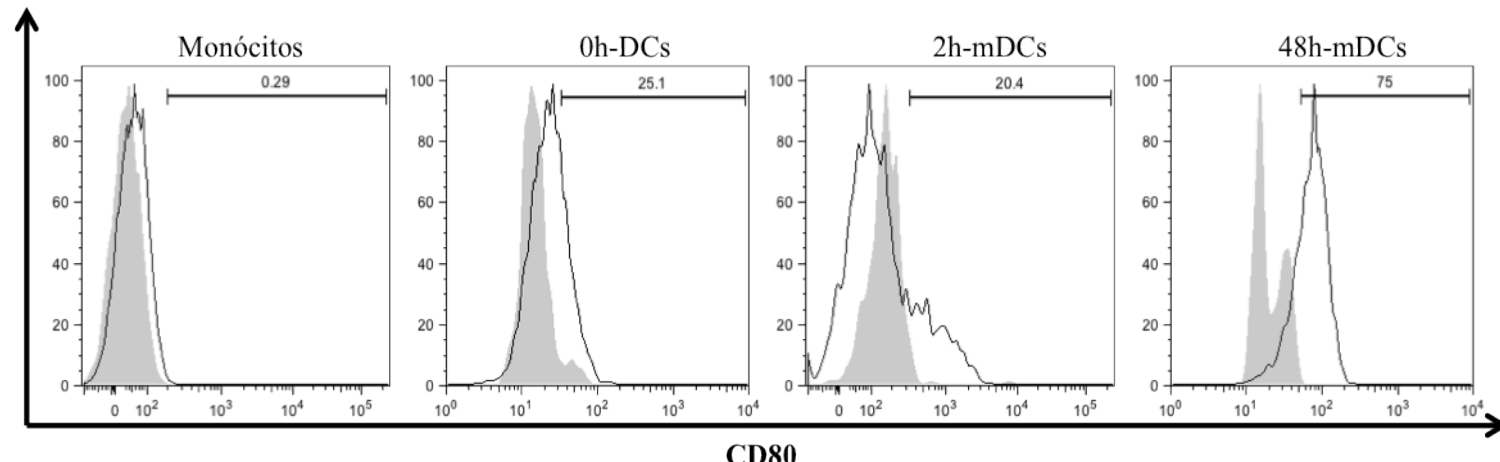

Figura 17 - Expressão de $\mathrm{CD80}^{+}$em monócitos, 0h-DCs, 2h-mDCs e 48h-mDCs. (A) Porcentagem de células $\mathrm{CD}^{+} 0^{+}$em monócitos (calculada dentro da população de células vivas), $0 \mathrm{~h}-\mathrm{DCs}, 2 \mathrm{~h}-\mathrm{mDCs}$ e $48 \mathrm{~h}-\mathrm{mDCs}$ (dentro da população CD11 c $\left.{ }^{+} \mathrm{HLA}_{-\mathrm{DR}}{ }^{+}\right)$. Barras indicam o erro padrão; $(* * *)$ indica $\mathrm{p}<0,0001,(* *)$ indica $\mathrm{p}<0,0050,(*)$ indica $\mathrm{p}<0,0238 ; \mathrm{n}=4$. (B) MFI relativa de CD80, calculada dividindo-se o valor da MFI da população positiva para CD80 pelo valor da MFI do tubo sem marcação. (C) Histogramas representativos da expressão da molécula de superfície $\mathrm{CD} 80$; as células não marcadas estão representadas em cinza e as marcadas, em preto. 
Já a porcentagem de células positivas para molécula CD86 apresentou-se ligeiramente aumentada conforme a diferenciação de monócitos em DCs (Figura 18A), o que também foi observado na MFI relativa (Figuras 18B).

A

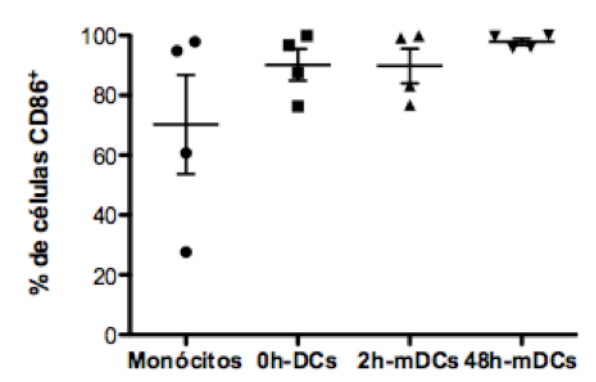

B

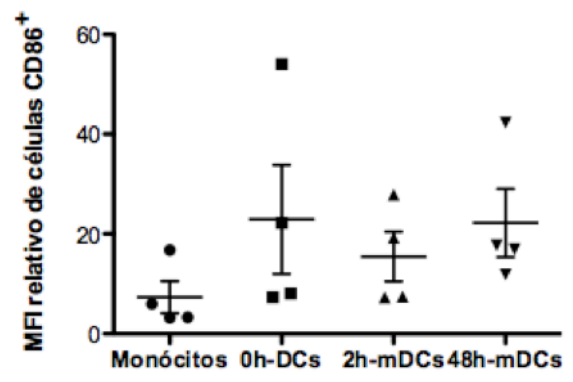

C

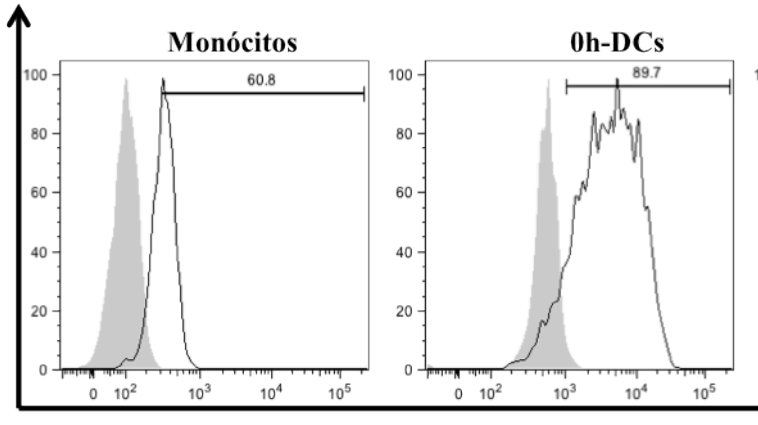

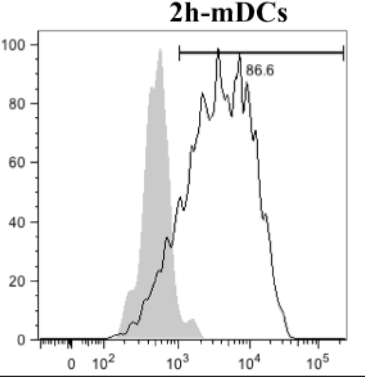

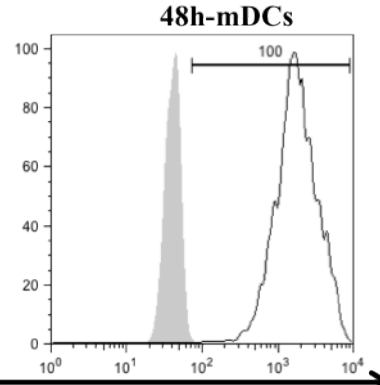

CD86

Figura 18 - Expressão de $\mathrm{CD86}^{+}$em monócitos, 0h-DCs, 2h-mDCs e 48h-mDCs. (A) Porcentagem de células $\mathrm{CD}^{+} 6^{+}$em monócitos (calculada dentro da população de células vivas), $0 \mathrm{~h}-\mathrm{DCs}, 2 \mathrm{~h}-\mathrm{mDCs}$ e $48 \mathrm{~h}-\mathrm{mDCs}$ (dentro da população CD11 ${ }^{+}$HLA-DR $^{+}$). Barras indicam o erro padrão; $p>0,05 ; n=4$. (B) MFI relativa de CD86, calculada dividindo-se o valor da MFI da população positiva para CD86 pelo valor da MFI do tubo sem marcação. (C) Histogramas representativos da expressão da molécula de superfície CD86; as células não marcadas estão representadas em cinza e as marcadas, em preto. 
Outra molécula de superfície analisada em nossa cultura foi o indicador de maturação das DCs, o CD83. No grupo 48h-mDCs houve um aumento significante de expressão quando comparamos com o início da diferenciação e aos monócitos (Figuras 19A e B).

A

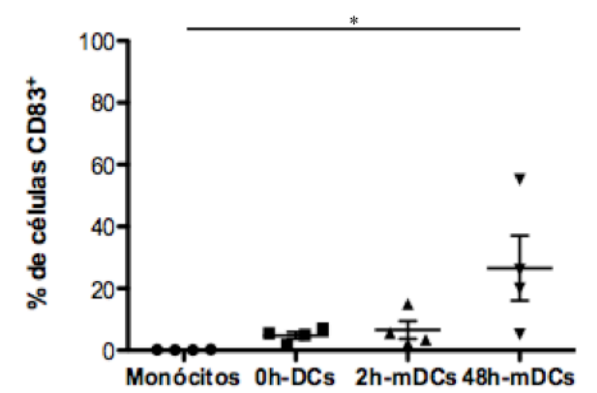

B

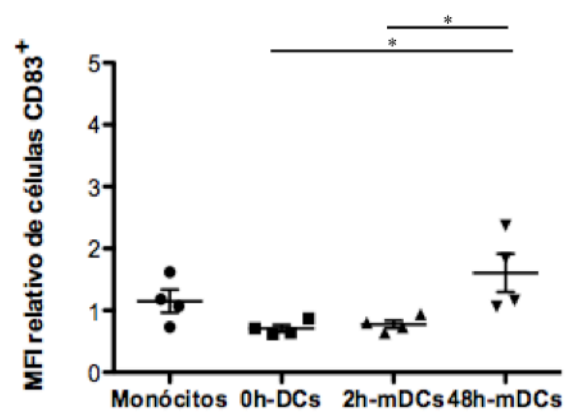

C
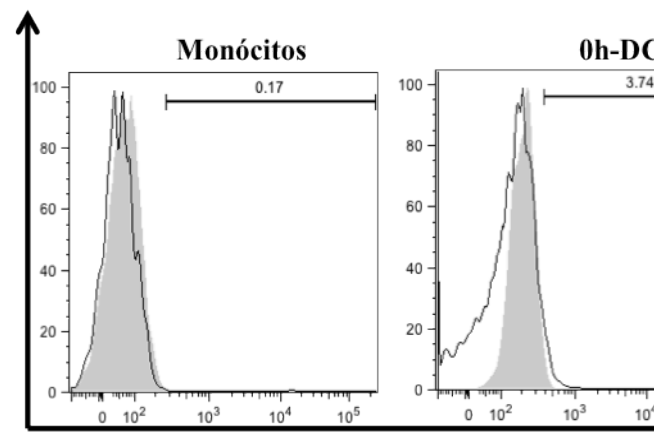

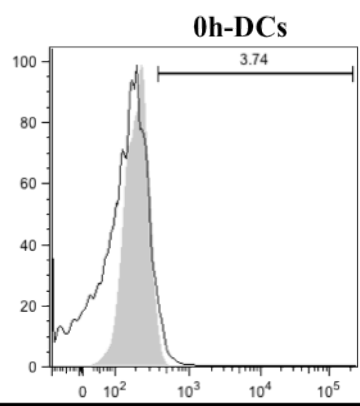

2h-mDCs

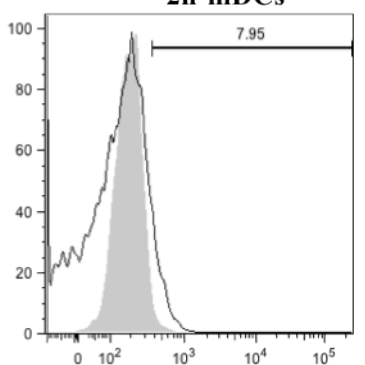

48h-mDCs

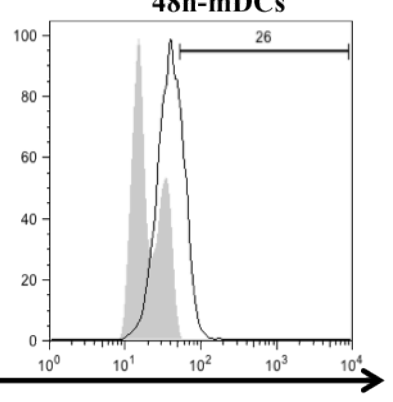

CD83

Figura 19 - Expressão de $\mathrm{CD83}^{+}$em monócitos, 0h-DCs, 2h-mDCs e 48h-mDCs. (A) Porcentagem de células $\mathrm{CD}^{+} 3^{+}$em monócitos (calculada dentro da população de células vivas), 0h-DCs, 2h-mDCs e 48h-mDCs (dentro da população CD11 $c^{+} H_{L A}-D^{+}{ }^{+}$. Barras indicam o erro padrão; (*) indica $\mathrm{p}<0,0238$; $\mathrm{n}=4$. (B) MFI relativa de CD83, calculada dividindo-se o valor da MFI da população positiva para CD83 pelo valor da MFI do tubo sem marcação. (C) Histogramas representativos da expressão da molécula de superfície CD83; as células não marcadas estão representadas em cinza e as marcadas, em preto. 
Também analisamos a molécula de superfície CD1a, que é expressa em DCs, onde está envolvida na apresentação de lipídeos e glicolipídeos para os linfócitos T. Nossos resultados mostraram que a expressão de CD1a mostrou grande variabilidade entre os diferentes doadores, mas pouca variação na porcentagem de células positivas e MFI relativa nas diferentes populações de um mesmo doador (Figuras 20A e B).

A

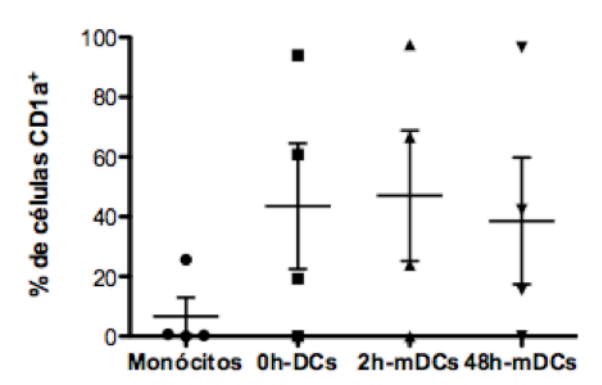

B

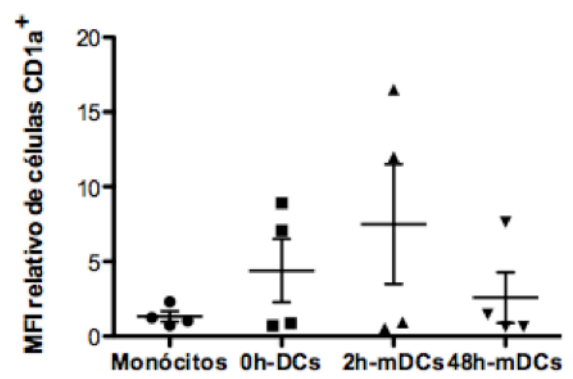

C

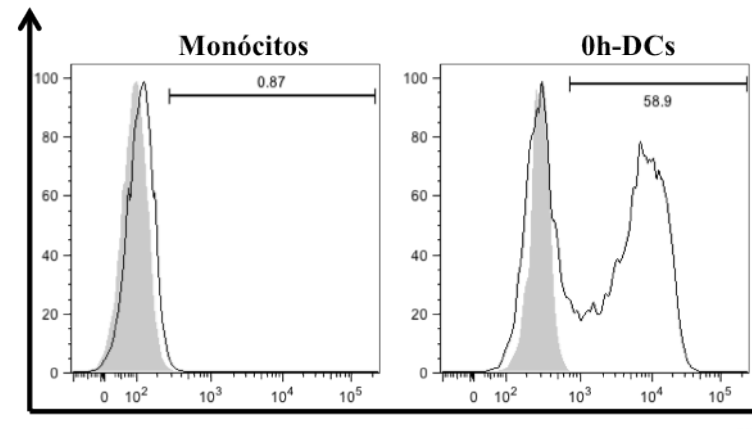

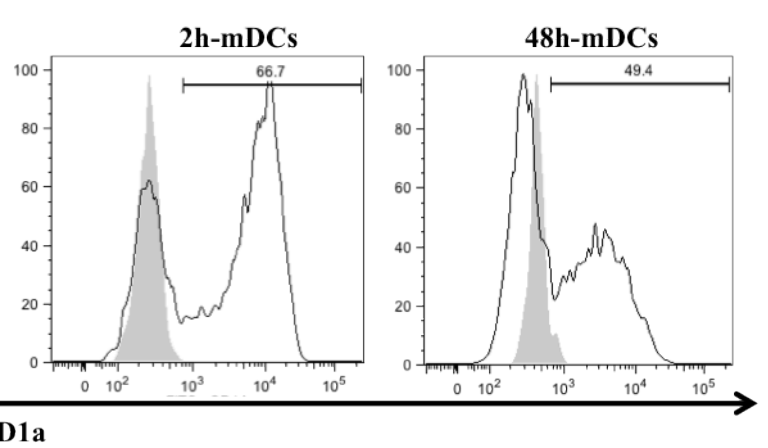

Figura 20 - Expressão de CD1a ${ }^{+}$em monócitos, 0h-DCs, 2h-mDCs e 48h-mDCs. (A) Porcentagem de células $\mathrm{CD}^{+} \mathrm{a}^{+}$em monócitos (calculada dentro da população de células vivas), $0 \mathrm{~h}-\mathrm{DCs}, 2 \mathrm{~h}-\mathrm{mDCs}$ e $48 \mathrm{~h}-\mathrm{mDCs}$ (dentro da população CD11 ${ }^{+}$HLA-DR $^{+}$). Barras indicam o erro padrão; $p>0,05 ; n=4$. (B) MFI relativa de CD1a, calculada dividindo-se o valor da MFI da população positiva para CD1a pelo valor da MFI do tubo sem marcação. (C) Histogramas representativos da expressão da molécula de superfície CD1a; as células não marcadas estão representadas em cinza e as marcadas, em preto. 
Já a molécula de superfície CD209, a qual é considerada um marcador de DCs por sua elevada presença tanto em DCs imaturas como em maduras, não foi expressa em monócitos, enquanto nos grupos 0h-DCs, $2 \mathrm{~h}-\mathrm{mDC}$ e $48 \mathrm{~h}-\mathrm{mDC}$ alta expressão pode ser observada (Figura 21A). Entretanto, não observamos diferenças significantes na MFI relativa desses grupos (Figura 21B).

A

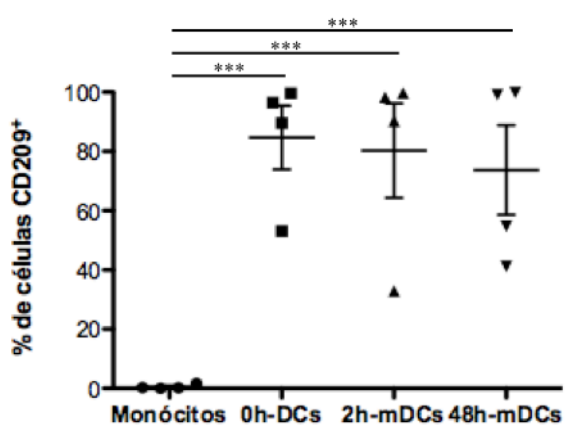

B

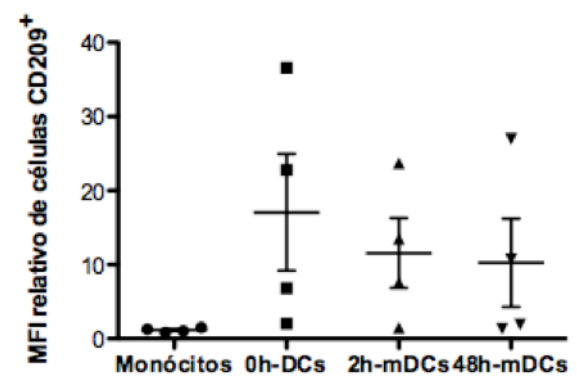

2h-mDCs

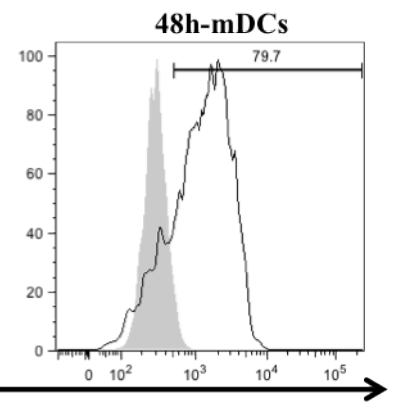

CD209

Figura 21 - Expressão de CD209 ${ }^{+}$em monócitos, 0h-DCs, 2h-mDCs e 48h-mDCs. (A) Porcentagem de células CD209 ${ }^{+}$em monócitos (calculada dentro da população de células vivas), $0 \mathrm{~h}-\mathrm{DCs}, 2 \mathrm{~h}-\mathrm{mDCs}$ e $48 \mathrm{~h}-\mathrm{mDCs}$ (dentro da população CD11 $\mathrm{c}^{+}$HLA-DR ${ }^{+}$). Barras indicam o erro padrão; $(* * *)$ indica $\mathrm{p}<0,0001 ; \mathrm{n}=4$. (B) MFI relativa de CD209, calculada dividindo-se o valor da MFI da população positiva para CD209 pelo valor da MFI do tubo sem marcação. (C) Histogramas representativos da expressão da molécula de superfície CD209; as células não marcadas estão representadas em cinza e as marcadas, em preto. 
Por fim, analisamos as moléculas de superfície CCR7 e PD-L1. Surpreendentemente, não observamos nenhuma diferença na porcentagem de células e na MFI relativa para molécula CCR7 nos grupos 2h-mDCs e 48h-mDCs (Figuras 22A e B). Contudo, podemos notar a presença dessa molécula em monócitos, tanto na porcentagem de células, como na MFI relativa (Figuras 22A e B).

A

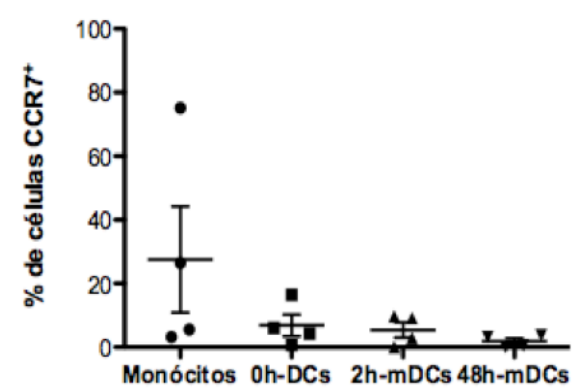

B

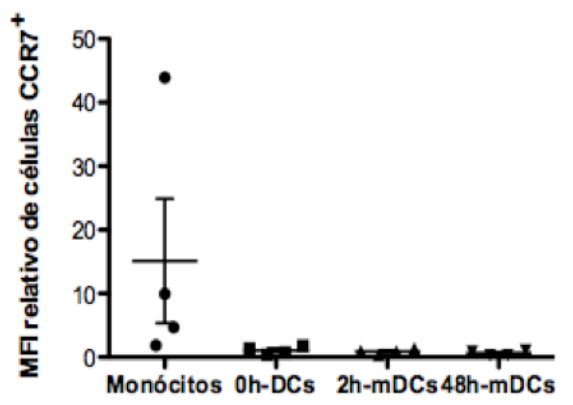

C

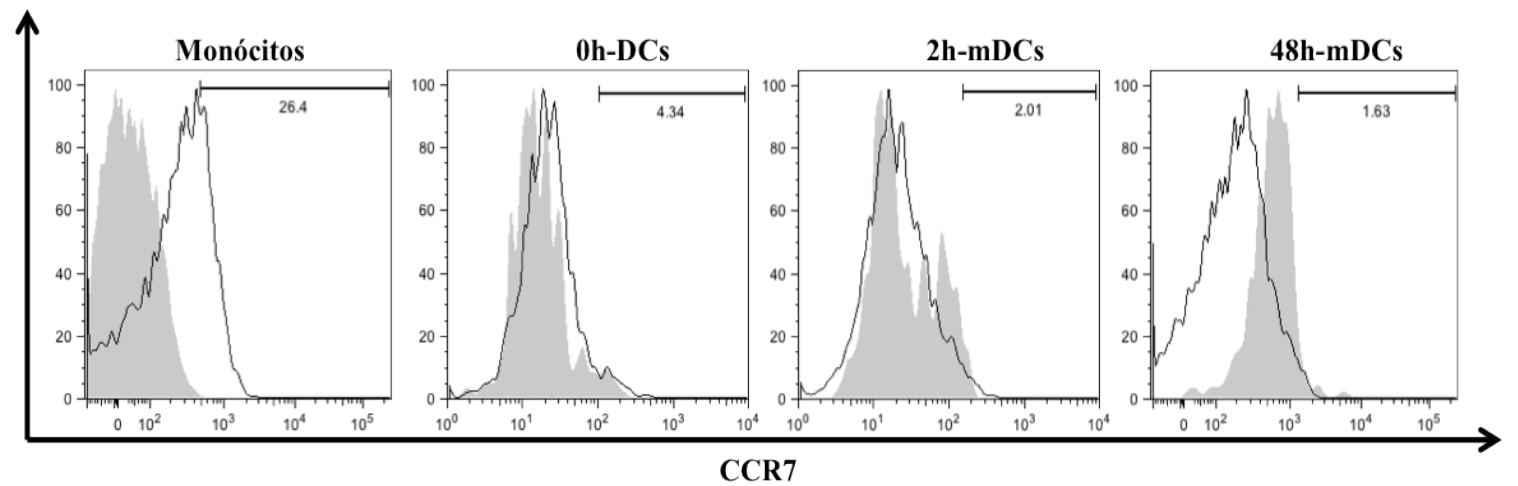

Figura 22 - Expressão de CCR7 $7^{+}$em monócitos, 0h-DCs, $2 \mathrm{~h}-\mathrm{mDCs}$ e 48h-mDCs. (A) Porcentagem de células $\mathrm{CCR} 7^{+}$em monócitos (calculada dentro da população de células vivas), 0h-DCs, 2h-mDCs e 48h-mDCs (dentro da população CD11 $c^{+}$HLA-DR $^{+}$). Barras indicam o erro padrão; $p>0,05 ; n=4$. (B) MFI relativa de CCR7, calculada dividindo-se o valor da MFI da população positiva para CCR7 pelo valor da MFI do tubo sem marcação. (C) Histogramas representativos da expressão da molécula de superfície CCR7; as células não marcadas estão representadas em cinza e as marcadas, em preto. 
Já a expressão de PD-L1 por DCs está associada com um perfil tolerogênico ou regulatório. Os resultados de fenotipagem apresentaram um aumento significativo tanto na porcentagem de células, quanto na MFI relativa de PD-L1 no grupo 48h-mDCs em comparação aos grupos monócitos, 0h-DCs e 2h-mDCs (Figuras 23A e B). Ainda, observamos um aumento significativo da porcentagem de células expressando PD-L1 entre os grupos 0h-DCs e monócitos.

A

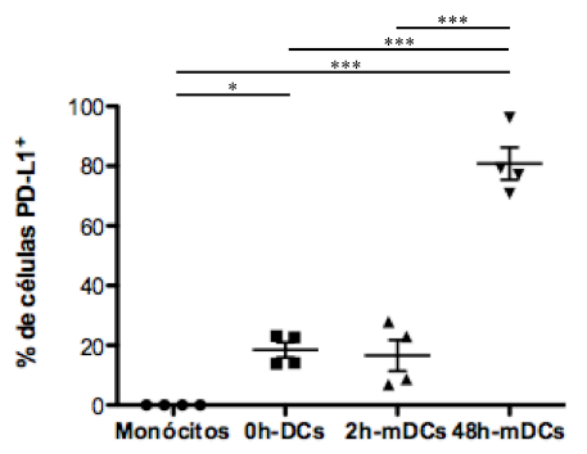

B

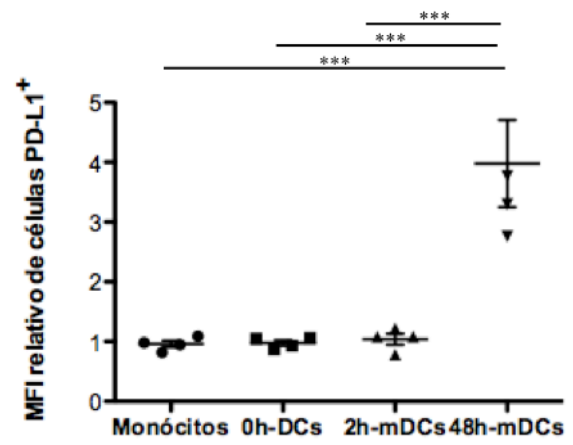

C
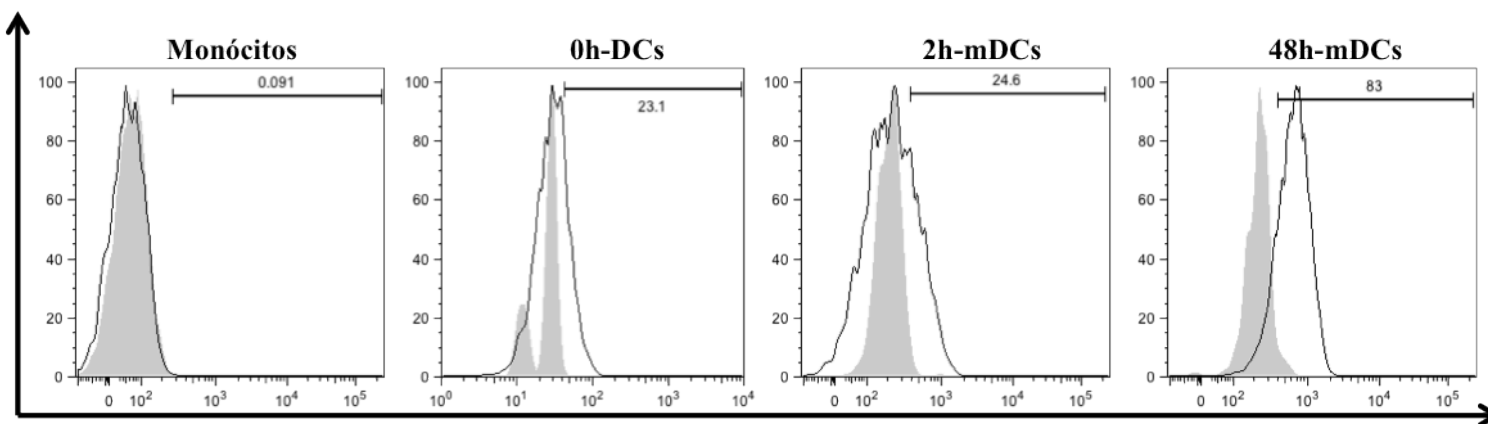

PD-L1

Figura 23 - Expressão de PD-L1 ${ }^{+}$em monócitos, 0h-DCs, 2h-mDCs e 48h-mDCs. (A) Porcentagem de células PD-L1 ${ }^{+}$em monócitos (calculada dentro da população de células vivas), 0h-DCs, 2h-mDCs e 48h-mDCs (dentro da população CD11 $\mathrm{c}^{+} \mathrm{HLA}_{\mathrm{DLR}}{ }^{+}$). Barras indicam o erro padrão; $(* * *)$ indica $\mathrm{p}<0,0001,(*)$ indica $\mathrm{p}<0,0238 ; \mathrm{n}=4$. (B) MFI relativa de PD-L1, calculada dividindo-se o valor da MFI da população positiva para PD-L1 pelo valor da MFI do tubo sem marcação. (C) Histogramas representativos da expressão da molécula de superfície PD-L1; as células não marcadas estão representadas em cinza e as marcadas, em preto. 


\subsection{Análise dos testes para a escolha do tipo de matriz 3D}

Para se trabalhar com modelos 3D in vitro, muitos aspectos devem ser analisados, como o tipo de arcabouço a ser usado, diâmetro de poros, textura etc., como relatado por Lee, Cuddihy e Kotov (2008) e Dutta e Dutta (2009). Para escolher o melhor arcabouço a ser utilizado em nossos experimentos, foram testados: Algimatrix, Cell Fate Hydrogel e 3D Biotek. Todos os testes foram realizados com $48 \mathrm{~h}-\mathrm{mDCs}$ derivadas de monócitos cocultivadas com linfócitos alogenêicos.

Primeiramente, utilizando o Algimatrix, linfócitos e DCs foram marcados para as moléculas de superfície CD3 e CD11c (dados não mostrados). O arcabouço Algimatrix é feito de esponja de alginato com um diâmetro dos poros de 50 a $200 \mu \mathrm{m}$. Porém, por se tratar de uma esponja, sua consistência não favorece sua manipulação. Embora existam soluções da própria empresa para que esta esponja tenha maior estabilidade, seu custo acaba sendo elevado. Ainda, embora o crescimento de células em materiais baseados em alginato possa ter certas vantagens, não existem muito trabalhos mostrando como um produto feito de algas irá interagir molecularmente com células de mamíferos e polímeros naturais.

Outro teste realizado para a escolha da matriz, foi com o arcabouço Cell Fate Hydrogel. Neste experimento foi utilizado o mesmo grupo de células cocultivadas na matriz Algimatrix e marcadas com os mesmos anticorpos de superfície (dados não mostrados). O Cell Fate Hydrogel é uma matriz feita de celulose sintetizada por bactérias possuindo a mesma estrutura química da celulose sintetizada por plantas. Novamente, ainda não existem muitos trabalhos mostrando como o produto interage com células de mamíferos e polímeros naturais.

Por fim, o último teste realizado foi a análise da interação no ambiente tridimensional 3D Biotek. Porém, neste teste foi utilizada faloidina (marcador para filamentos de actina) ao invés dos anticorpos usados nos experimentos anteriores. Foi possível observar que essa matriz possibilita a interação das células com diferentes aspectos morfológicos (DCs e linfócitos), mesmo não se tendo discriminado os diferentes tipos de células presentes por marcações específicas (dados não mostrados). O arcabouço 3D Biotek é feito de poliestireno, material usado em placas de cultura, onde a grande maioria dos estudos in vitro de cultura de células 2D foram realizados, alterando apenas a conformação para 3D. Além disso, esses arcabouços de poliestireno são de vida útil longa, estáveis e tem estrutura reticular, lembrando a conformação da matriz extracelular de órgãos linfoides secundários como o linfonodo. Por essas características, optou-se por utilizar esta matriz 3D para todos os experimentos subsequentes. 


\subsection{Caracterização da rede colágena em linfonodo murino}

Sabendo que os colágenos do tipo I e III são os principais tipos de colágenos presentes nos linfonodos (CASTAÑOS-VELEZ; BIBERFELD; PATARROYO, 1995; KARTTUNEN et al., 1989; SOBOCINSKI et al., 2010) procurarmos determinar a relação entre os colágenos dos tipos III e I presente em linfonodos, além de evidenciar as regiões de prevalência de cada um destes colágenos. Primeiramente, analisamos a densidade das fibras na malha colágena formada através da coloração de Picro-Sirius, o que, indiretamente, nos dá uma noção da composição relativa da mesma (MONTES; JUNQUEIRA, 1991). Nossos resultados mostraram fibras colágenas mais espessas na região do hilo, no tecido conjuntivo subcapsular e na medula do linfonodo, enquanto fibras delgadas com aspecto reticular foram visualizadas nas regiões cortical e paracortical do órgão (Figuras 24A e B). 

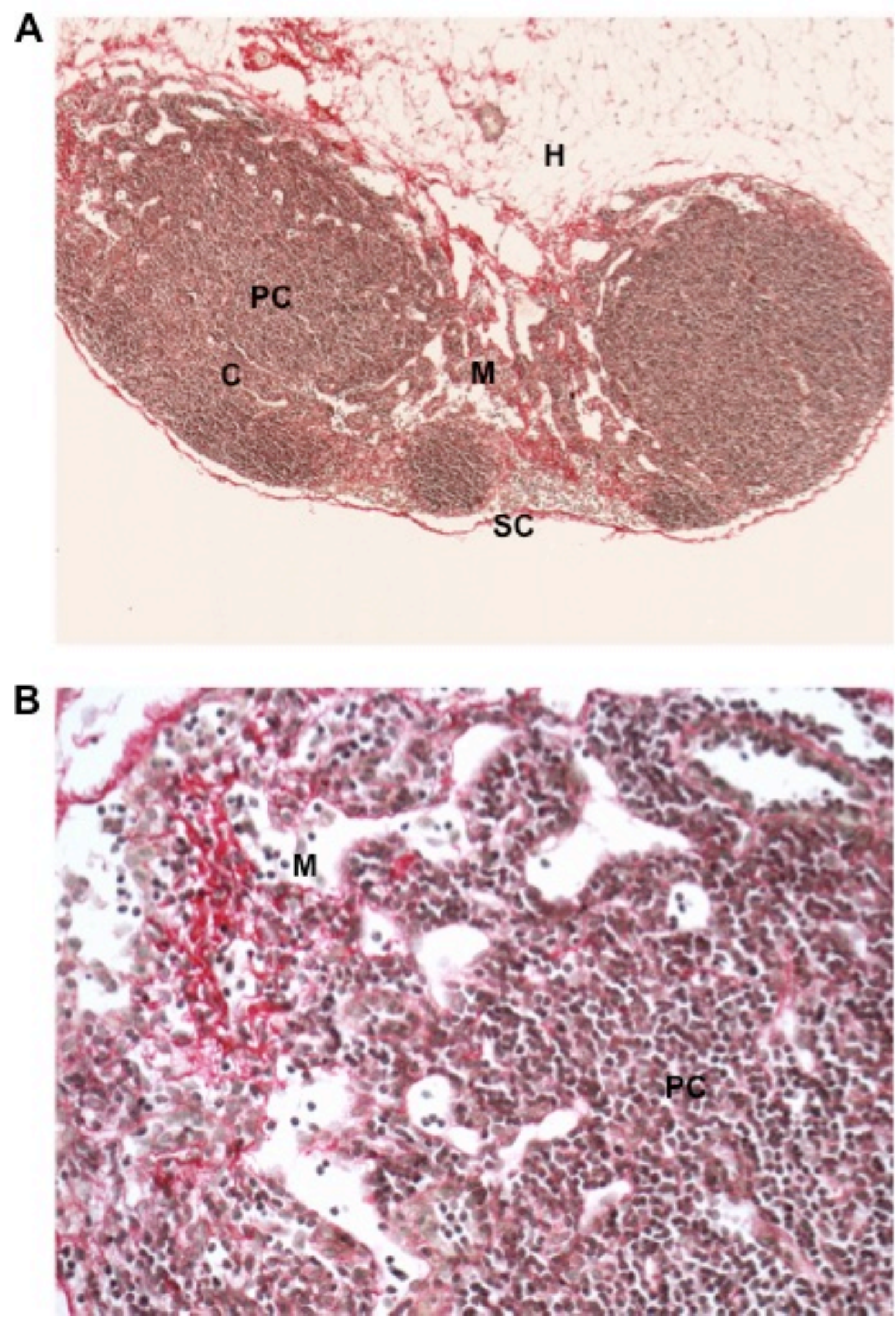

Figura 24 - Fotomicrografias de linfonodo corado com a coloração de picro-sírius observados em luz não-polarizada. (A) Corte histológico de um linfonodo em aumento 50x; (B) Corte histológico de um linfonodo mostando as fibras colágenas em aumento 400x. C - Região Cortical; H - Hilo; M - Região Medular; PC - Região Paracortical; SC - Região Subcapsular. 
Para completar esses dados, realizamos um ensaio de imunofluorescência com objetivo de confirmar a prevalência de colágenos dos tipos III e I nas mesmas amostras de linfonodos. Nossos resultados mostraram a presença de colágeno do tipo III nas regiões cortical/paracortical e na cápsula (Figura 25A), mas o colágeno tipo I só foi encontrado na região medular (dados não mostrados) e na cápsula (Figura 25B).

A

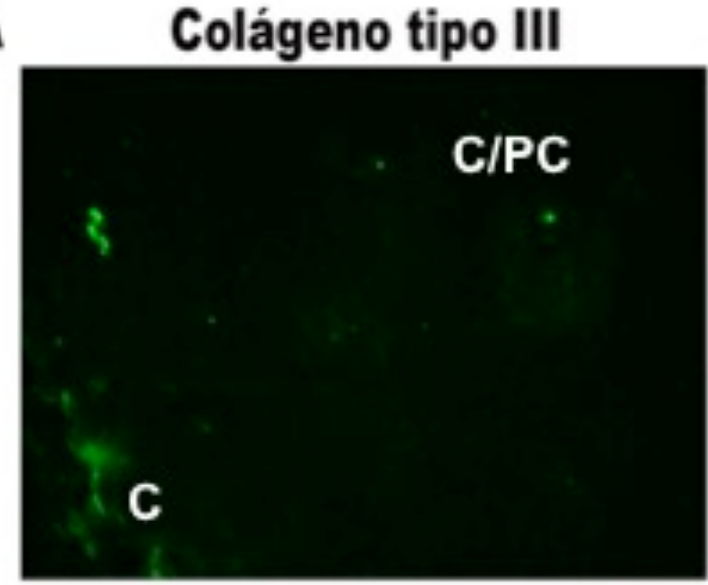

\section{B}

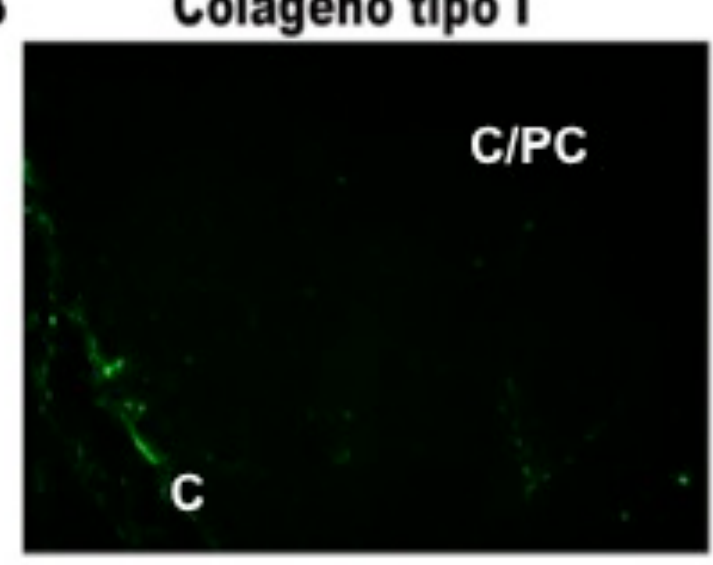

Merge

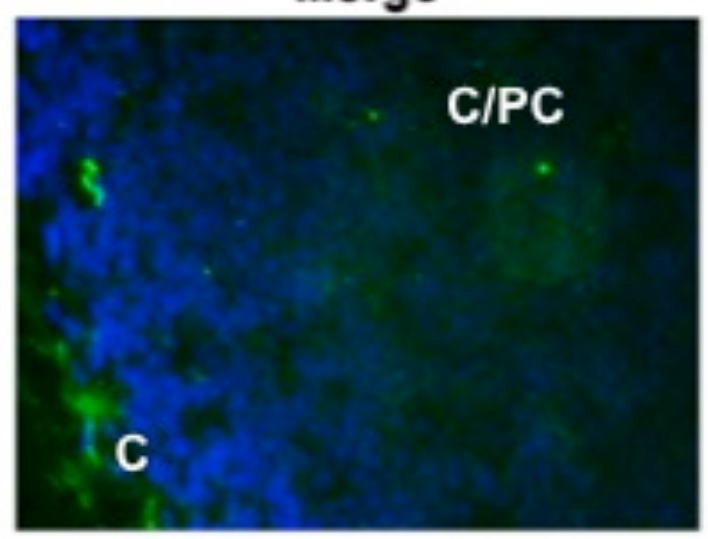

Merge

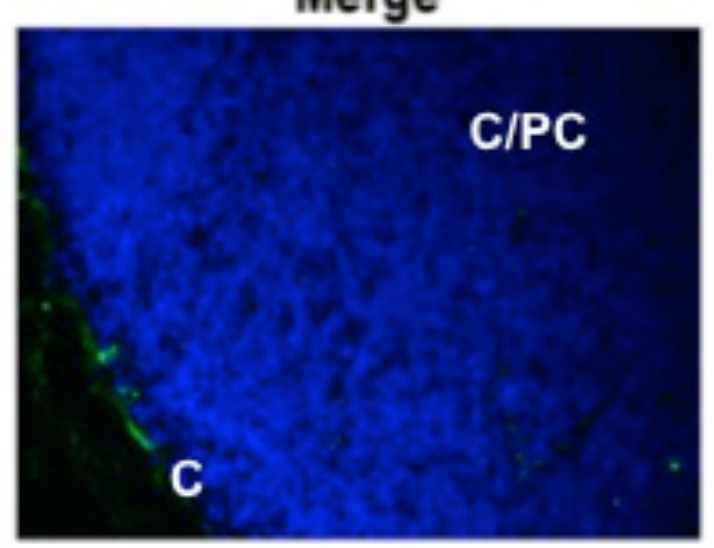

Figura 25 - Fotomicrografias de linfonodo marcado com colágenos do tipo III e I. (A) Corte histológico da região cortical e paracortical de um linfonodo marcado com colágeno do tipo III em verde e núcleos em azul. Aumento de 400x; (B) Corte histológico da região cortical e paracortical de um linfonodo marcado com colágeno do tipo I em verde e núcleo em azul. Aumento de 200x. C - Região Cortical; PC/C - Região Cortical/Região Paracortical. 


\subsection{Análises dos cocultivos em ambiente 3D}

Primeiramente, através do programa de análise Zen 2009 Light Edition, analisamos a duração das interações celulares das coculturas em ambiente $3 \mathrm{D}$ em modo $2 \mathrm{D}$, no qual eram consideradas a morfologia, a fluorescência e a proximidade das células. Porém, no decorrer dos experimentos, observamos ao visualizar as células somente em 2 dimensões muitos resultados falso-positivos de supostas interações. Através da correta análise em todas as dimensões possíveis ( 2 canais de fluorescência, os diferentes planos no eixo $\mathrm{Z}$ e os intervalos de tempo), as imagens foram digitalmente reconstruídas sequencialmente, com posterior formação de volumes. Isso nos permitiu a visualização da amostra em diversos ângulos, bem como a observação dos volumes formados ao longo dos diferentes intervalos de tempo dos experimentos. Isso nos permitiu observar que as mesmas células que, antes visualizados em 2D aparentavam interagir (Figura 26A), em 3D não o faziam (Figura 26B), confirmando os resultados falso-positivos obtidos anteriormente. Por conseguinte e a partir deste momento, todos os resultados apresentados foram analisados através deste segundo método descrito, utilizando 2 canais de fluorescência, os diferentes planos no eixo $\mathrm{Z}$ e os intervalos de tempo. 
A

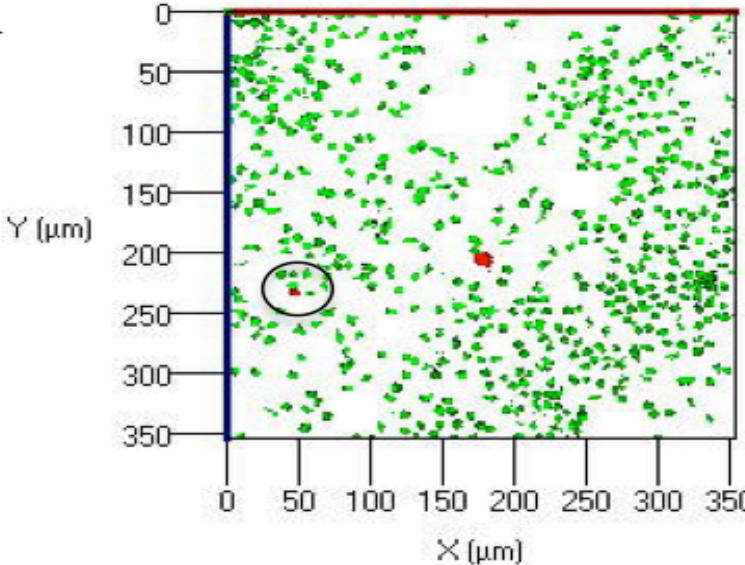

B

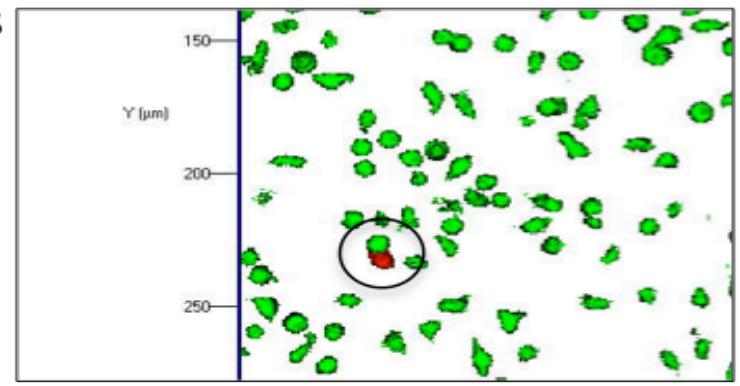

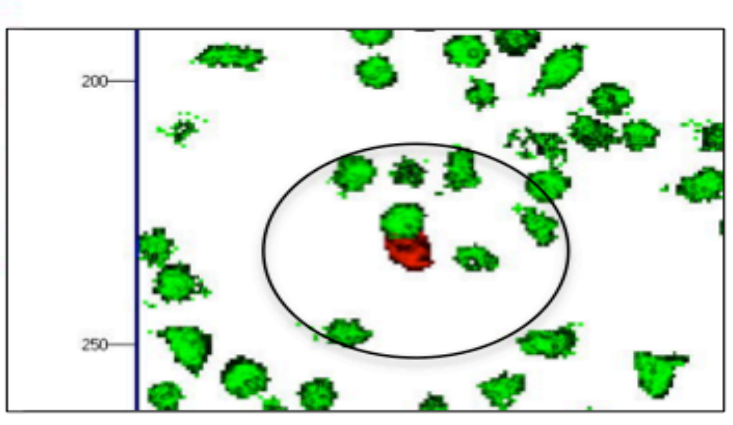
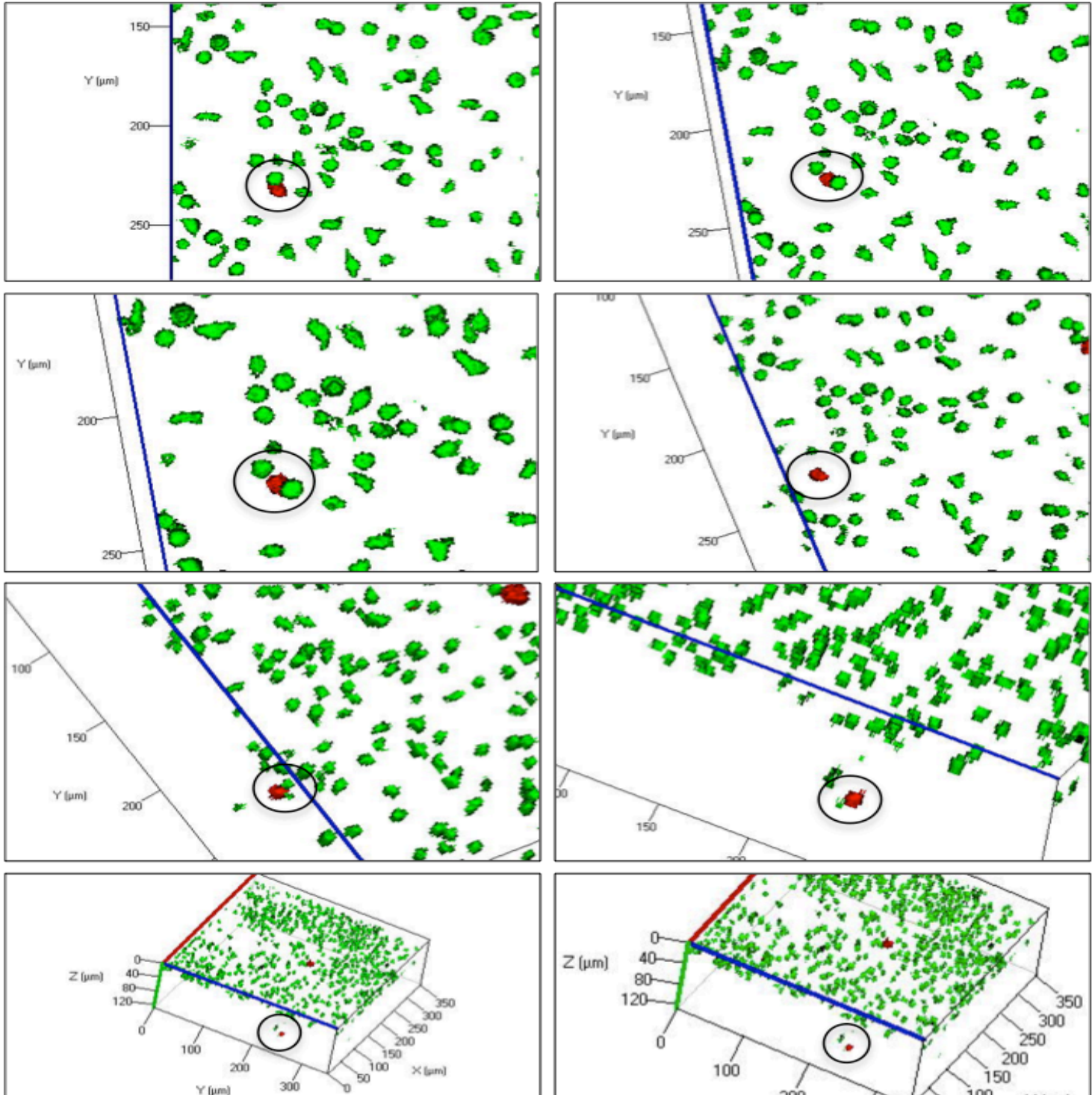
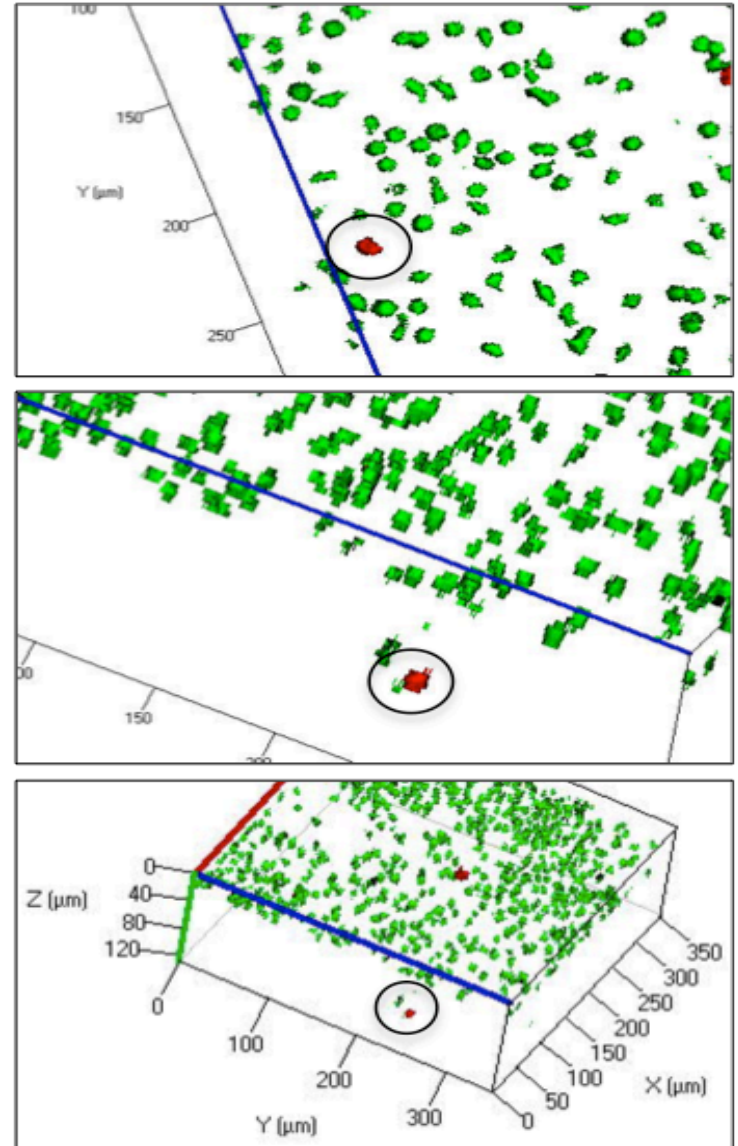

Figura 26 - Interações celulares em 2D vs. 3D. (A) Sequência de imagens da interação celular entre DCs e linfócitos T alogenêicos analisados em 2D. (B) Sequência de imagens da interação celular entre DCs e linfócitos T alogenêicos analisados em 3D; Círculos indicam a falsa "interação" entre DCs (vermelho) e Linfócito $\mathrm{T}$ alogenêicos (verde). 
Em resumo, passamos a realizar a análise das interações celulares, dos eixos $\mathrm{X}, \mathrm{Y}$ e $\mathrm{Z}$ (Figura 27) e a dimensão temporal (T), analisada em períodos sequenciais de 20 minutos. Para cada amostra, foram adquiridas 20 a 60 imagens em 5 campos escolhidos aleatoriamente e 11 a 56 secções do eixo $Z$ que variaram de 7,215 $\mu \mathrm{m}$ até $0,500 \mu \mathrm{m}$ e secções dos eixos $\mathrm{X}$ e Y, que variaram de 1,384 $\mu \mathrm{m}$ até $0,346 \mu \mathrm{m}$. Além disso, para a análise da duração das interações celulares foram considerados no mínimo 2 períodos (Figura 28) e, linfócitos que apenas tocaram as DCs brevemente ou tiveram contato menor do que o estipulado (2 períodos), foram desconsiderados (Figura 29).

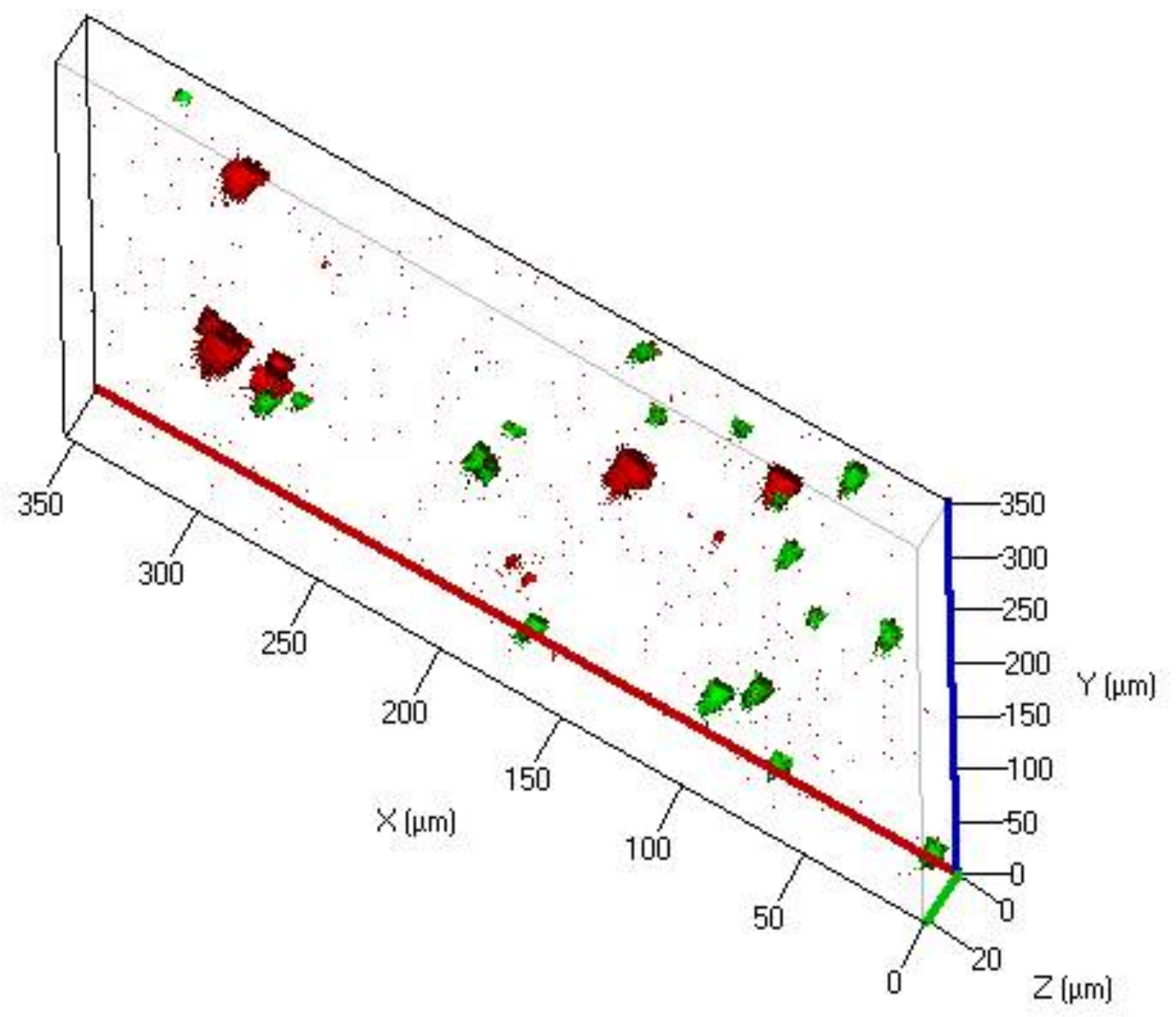

Figura 27 - Esquema mostrando as dimensões espaciais dos eixos $\mathbf{X}, \mathbf{Y}$ e $\mathrm{Z}$. Linha vermelha indica o eixo $\mathrm{X}$, linha verde o eixo $\mathrm{Z}$ e a linha azul o eixo $\mathrm{Y}$. DCs (vermelho) e Linfócitos $\mathrm{T}$ alogenêicos (verde). 

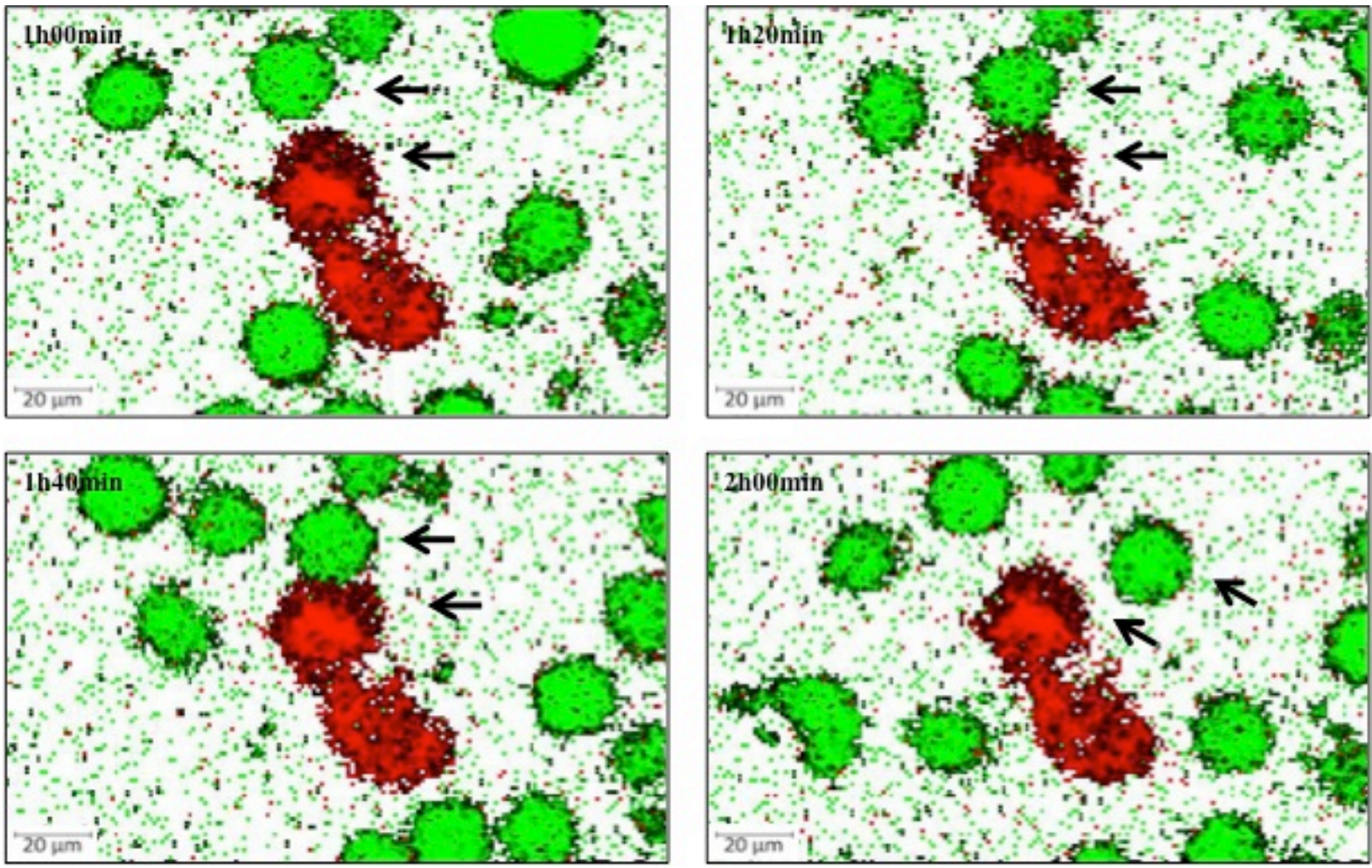

Figura 28 - Interação celular que foi considerada. Sequência de imagens da análise da duração das interações celulares que foram consideradas, no mínimo, $\geq 2$ períodos. Setas indicam a interação entre DCs (vermelho) e Linfócito $\mathrm{T}$ alogenêicos (verde).
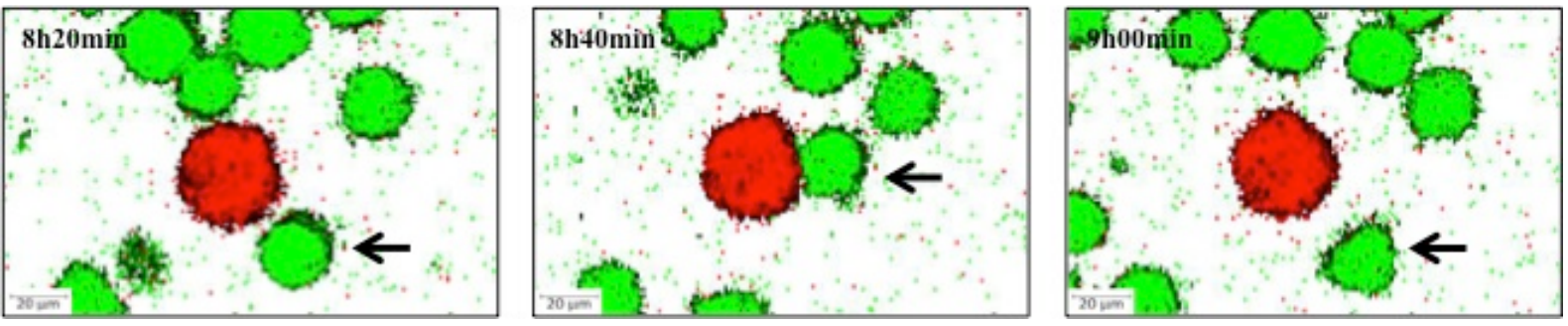

Figura 29 - Interação celular que foi desconsiderada. Sequência de imagens da a interação entre DCs e linfócitos $\mathrm{T}$ alogenêicos em apenas 1 período. DCs (vermelho) e Linfócito $\mathrm{T}$ alogenêicos (verde). Setas indicam o linfócito que "interagiu" apenas 1 intervalo de tempo entre os quadros.

\subsection{Escolha do modelo de estudo}

Baseado nesse tipo de análise da duração das interações celulares, o melhor modelo de estudo foi escolhido - arcabouço 3D Biotek tratado com colágeno do tipo III (STEPONAVICIUS-CRUZ et al., Submetido).

Em resumo, neste trabalho evidenciamos através de um novo modelo $3 \mathrm{D}$ in vitro a grande importância de se considerar o substrato colágeno do tipo III em estudos onde 
envolvam a interação de DCs e linfócitos T que ocorre em órgãos linfoides secundários, sendo assim, mais próximos de resultados esperados ao que ocorre in vivo.

\subsection{Análises das interações celulares entre DCs e Linfócitos $T$ nas coculturas em ambiente 3D}

A partir da escolha do melhor modelo de estudo, os grupos 0h-DCs, 2h-mDCs e 48hmDCs foram corados com CellTracker Red, adicionados ao arcabouço 3D tratado com colágeno do tipo III (Col III) ou não (Sem Col III) e cocultivados com linfócitos T CD $3^{+} \mathrm{CD}^{+}$ previamente corados em CFSE e linfócitos $\mathrm{T} \mathrm{CD}^{+} \mathrm{CD}^{+}$previamente corados em CellTracker Orange.

Nossa primeira análise foi a porcentagem de interações encontrados nos dois diferentes grupos: Sem Col III e Col III. Nós observamos que não houveram interações entre os diferentes tipos de DCs e linfócitos $\mathrm{T} \mathrm{CD}^{+} \mathrm{CD}^{+}$no grupo Sem Col III (Figura 30A). Embora foram encontradas diferenças estatisticamente significantes entre os grupos Sem Col e Col III quando as DCs não foram tratadas com TNF- $\alpha$ ou apenas tratadas por 2 horas (Figura 30A). Já a média da porcentagem de interações celulares dos linfócitos $\mathrm{T} \mathrm{CD} 3^{+} \mathrm{CD} 4^{+}$ com 0h-DCs, $2 \mathrm{~h}-\mathrm{mDCs}$ e $48 \mathrm{~h}-\mathrm{mDC}$ no grupo Col III foram 9,5\%, $17 \%$ e 18\%, repectivamente (Figura 30A). Podemos observar também que de todas as DCs nos grupos 0hDCs, $2 \mathrm{~h}-\mathrm{mDCs}$ e $48 \mathrm{~h}-\mathrm{mDCs}$ apenas $5 \%, 9 \%$ e 3\% delas, respectivamente, interagiram com algum linfócito $\mathrm{T} \mathrm{CD}^{+} \mathrm{CD}^{+}$no grupo Sem Col III e 4\%, 2\% e 4\% no grupo Col III (Figura 30B).

A

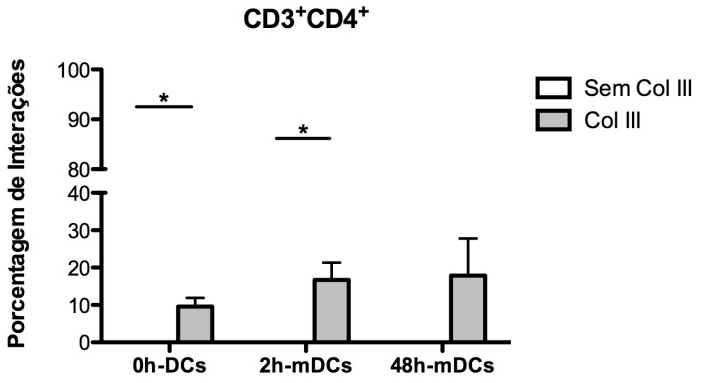

B

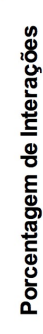

$\mathrm{CD}^{+} \mathrm{CDB}^{+}$

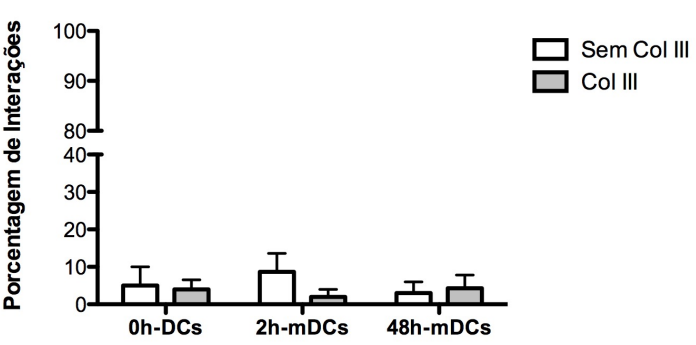

Figura 30 - Porcentagem das interações celulares em ambiente 3D. Porcentagem das interações celulares dos grupos 0h-DCs, 2h-mDCs e 48h-mDCs e (A) linfócitos $\mathrm{T} \mathrm{CD}^{+} \mathrm{CD}^{+}$e (B) linfócito $\mathrm{T} \mathrm{CD}^{+} \mathrm{CD}^{+}$nos grupos Sem Col III e Col III; Barras indicam o erro padrão; (*) indica $\mathrm{p}<0,0500$; Grupo Sem Col III $\mathrm{n}=3$ e grupo Col III $\mathrm{n}=7$. 
Nosso próximo passo foi observar o tempo das interações celulares (Figura 31). Como observamos a ausência de interações celulares entre os diferentes tipos de DCs e linfócitos $\mathrm{T} \mathrm{CD}^{+} \mathrm{CD}^{+}$no grupo Sem Col III (Figura 31A), esse e os próximos itens não serão avaliados. Entretanto foram encontradas diferenças estatisticamente significantes entre os grupos Sem Col e Col III nos três tipos de DCs: 0h-DCs, 2h-mDCs e 48h-mDCs (Figura 31A). A média do tempo das interações celulares foi de 75, 62 e 42 minutos para 0h-DCs, $2 \mathrm{~h}$ mDCs e 48h-mDCs, respectivamente, no grupo Col III (Figura 31A). Os tempos de interações celulares observados nos grupos Sem Col III foram de 165 minutos no grupo 0hDCs, 30 minutos no grupo $2 \mathrm{~h}-\mathrm{mDC}$ e 15 minutos no grupo $48 \mathrm{~h}-\mathrm{mDC}$ quando interagiram com linfócitos $\mathrm{T} \mathrm{CD}^{+} \mathrm{CD}^{+}$(Figura 31B). Já o tempo das interações celulares no ambiente 3D Biotek tratado com colágeno do tipo III entre linfócitos $\mathrm{T} \mathrm{CD} 3^{+} \mathrm{CD} 8^{+}$e $0 \mathrm{~h}-\mathrm{DCs}, 2 \mathrm{~h}-\mathrm{mDCs}$ e 48h-mDCs foram de 34, 17, 40 minutos, respectivamente (Figura 31B). Vale ressaltar que houve uma diminuição estatisticamente significante do tempo de interação de linfócitos $\mathrm{T}$ $\mathrm{CD}^{+} \mathrm{CD}^{+}$com o grupo $0 \mathrm{~h}-\mathrm{DCs}$ para $2 \mathrm{~h}-\mathrm{mDC}$ na matriz 3D tratada com colágeno tipo III (Figura 31B).

A

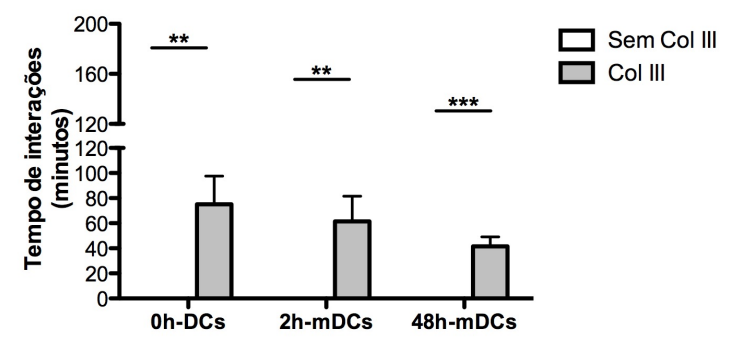

B $\mathrm{CD}^{+} \mathrm{CDB}^{+}$

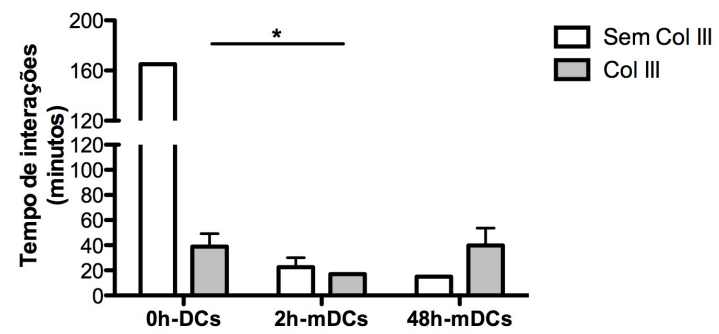

Figura 31 - Tempo de interação celular no ambiente 3D na presença ou ausência de

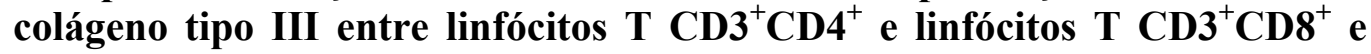
DCs em diferentes estágios de maturação. Tempo de interações celulares entre 0h-DCs, 2h-mDCs e 48h-mDCs cocultivadas com (A) linfócitos T CD3 ${ }^{+} \mathrm{CD} 4^{+} \mathrm{e}$ (B) linfócitos $\mathrm{T} \mathrm{CD}^{+} \mathrm{CD}^{+}$nos grupos Sem Col III e Col III; Barras indicam o erro padrão; $(* * *)$ indica $\mathrm{p}<0,0001,(* *)$ indica $\mathrm{p}<0,0099,\left(^{*}\right)$ indica $\mathrm{p}<0,0500$; Grupo Sem Col III n=3 e grupo Col III $n=7$.

Além disso, observamos diferentes tipos de interações nos grupos Sem Col III e Col III, sendo que no grupo Sem Col III, as interações entre DCs dos grupos 0h-DCs e 2h-mDCs ocorreram sempre com linfócitos $\mathrm{T} C D 3^{+} \mathrm{CD}^{+}$e foram caracterizadas pela interação apenas com um único linfócito, enquanto no grupo 48h-mDCs, as interações com linfócitos $\mathrm{T}$ $\mathrm{CD}^{+}{ }^{\mathrm{CD}} 8^{+}$foram sempre com mais de dois linfócitos diferentes (Tabelas 7 e 8). Já no grupo Col III, não ocorreram alterações evidentes com relação aos diferentes grupos de DCs 
interagindo com linfócitos $\mathrm{T} \mathrm{CD}^{+} \mathrm{CD}^{+}$, em todos houve uma distribuição heterogênea dos tipos de interação, com prevalência de interações com apenas um linfócito (Tabela 7). No entanto, quando observamos os tipos de interações com linfócitos $\mathrm{T} \mathrm{CD}^{+} \mathrm{CD}^{+}$, foi possível ver uma mudança no perfil desses tipos de interações, sendo que nos grupos 0h-DCs e 2hmDCs houve uma predominância de interações com um único linfócito e no grupo 48h-mDCs todas as interações foram repetidas com o mesmo linfócito (Tabela 8).

Tabela 7 - Porcentagem dos diferentes tipos de interações celulares entre os grupos 0hDCs, $2 \mathrm{~h}-\mathrm{mDCs}$ e $48 \mathrm{~h}-\mathrm{mDCs}$ e linfócitos $\mathrm{T} \mathrm{CD3}^{+} \mathrm{CD}^{+}$no grupo Sem Col III e no grupo Col III.

\begin{tabular}{|c|c|c|c|c|c|c|}
\hline \multirow[t]{2}{*}{ ilo gr apo cor } & \multicolumn{3}{|c|}{ Sem Col III } & \multicolumn{3}{|c|}{ Col III } \\
\hline & $\begin{array}{l}\text { Oh- } \\
\text { DCs }\end{array}$ & $\begin{array}{c}2 \mathrm{~h}- \\
\mathrm{mDCs}\end{array}$ & $\begin{array}{c}48 \mathrm{~h}- \\
\text { mDCs }\end{array}$ & $\begin{array}{l}\text { Oh- } \\
\text { DCs }\end{array}$ & $\begin{array}{c}2 \mathrm{~h}- \\
\mathrm{mDCs}\end{array}$ & $\begin{array}{c}48 \mathrm{~h}- \\
\text { mDCs }\end{array}$ \\
\hline $\begin{array}{l}\text { a) DC interagindo com } \\
\text { apenas } 1 \text { linfócito }\end{array}$ & - & - & - & $50 \%$ & $54,5 \%$ & $50 \%$ \\
\hline $\begin{array}{l}\text { b) DC interagindo com } \\
\text { o mesmo linfócito } \\
\text { repetidas vezes }\end{array}$ & - & - & - & $37,5 \%$ & $18,2 \%$ & $16,6 \%$ \\
\hline $\begin{array}{l}\text { c) DC interagindo com } \\
\text { mais de } 2 \text { linfócitos } \\
\text { diferentes }\end{array}$ & - & - & - & - & $18,2 \%$ & $33,4 \%$ \\
\hline $\begin{array}{l}\text { d) DC interagindo com } \\
\text { mais de } 2 \text { linfócitos } \\
\text { sendo que com algum } \\
\text { desses linfócitos, mais } \\
\text { de uma vez }\end{array}$ & - & - & - & $12,5 \%$ & $9,1 \%$ & - \\
\hline
\end{tabular}

(-) sem interação celular observada

Tabela 8 - Porcentagem dos diferentes tipos de interações celulares entre os grupos 0hDCs, 2h-mDCs e 48h-mDCs e linfócitos $\mathrm{T} \mathrm{CD3}^{+} \mathrm{CD8}^{+}$no grupo Sem Col III e no grupo Col III.

\begin{tabular}{l|c|c|c|c|c|c}
\cline { 2 - 6 } & \multicolumn{3}{c|}{ Sem Col III } & \multicolumn{3}{c}{ Col III } \\
\cline { 2 - 7 } & $\begin{array}{c}\text { 0h- } \\
\text { DCs }\end{array}$ & $\begin{array}{c}\mathbf{2 h}- \\
\text { mDCs }\end{array}$ & $\begin{array}{c}\mathbf{4 8 h}- \\
\text { mDCs }\end{array}$ & $\begin{array}{c}\text { 0h- } \\
\text { DCs }\end{array}$ & $\begin{array}{c}\mathbf{2 h}- \\
\text { mDCs }\end{array}$ & $\begin{array}{c}\mathbf{4 8 h} \text { mDCs } \\
\text { mDC }\end{array}$ \\
\hline $\begin{array}{l}\text { a) DC interagindo com } \\
\text { apenas 1 linfócito }\end{array}$ & $100 \%$ & $100 \%$ & - & $50 \%$ & $100 \%$ & - \\
\hline $\begin{array}{l}\text { b) DC interagindo com } \\
\text { o mesmo linfócito } \\
\text { repetidas vezes }\end{array}$ & - & - & - & $25 \%$ & - & $100 \%$ \\
\hline $\begin{array}{l}\text { c) DC interagindo com } \\
\text { mais de 2 linfócitos } \\
\text { diferentes }\end{array}$ & - & - & $100 \%$ & - & - & - \\
$\begin{array}{l}\text { d) DC interagindo com } \\
\text { mais de 2 linfócitos } \\
\text { sendo que com algum } \\
\text { desses linfócitos, mais } \\
\text { de uma vez }\end{array}$ & - & - & - & $25 \%$ & - & - \\
\hline
\end{tabular}

(-) sem interação celular observada 
Em seguida, analisamos na matriz 3D tratada ou não com colágeno do tipo III a velocidade de migração das DCs e dos linfócitos T. Primeiramente observamos a velocidade de migração das DCs em diferentes estágios de maturação no ambiente 3D Biotek tratada ou não com colágeno do tipo III e que não interagiram com linfócitos T (Figura 32). Nossos resultados mostraram que a média da migração de $0 \mathrm{~h}-\mathrm{DCs}$, $2 \mathrm{~h}-\mathrm{mDCs}$ e $48 \mathrm{~h}-\mathrm{mDCs}$ no grupo Sem MEC foi de $11 \mu \mathrm{m} /$ minuto, $9 \mu \mathrm{m} /$ minuto e $13 \mu \mathrm{m} /$ minuto (Figura 32). Essa velocidade de migração de DCs diminuiu quando a matriz foi tratada com colágeno do tipo III para 7 $\mu \mathrm{m} /$ minuto no grupo 0h-DCs e no grupo $48 \mathrm{~h}-\mathrm{mDCs}$ para $10 \mu \mathrm{m} /$ minuto (Figura 32), mas aumentou para $11 \mu \mathrm{m} /$ minuto no grupo $2 \mathrm{~h}-\mathrm{mDCs}$.

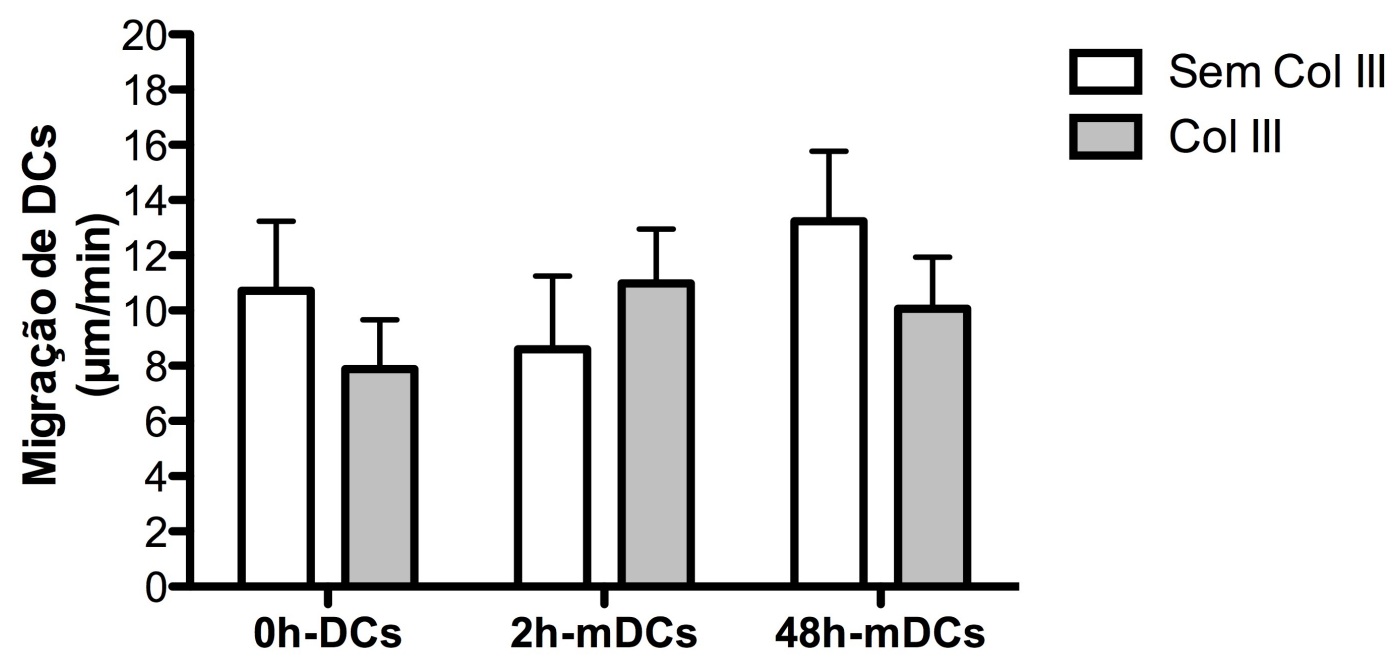

Figura 32 - Migração de DCs sem contato com nenhum linfócito T em um ambiente 3D tratado com colágeno tipo III ou não. Migração de $0 \mathrm{~h}-\mathrm{DCs}, 2 \mathrm{~h}-\mathrm{mDCs}$ e $48 \mathrm{~h}$ mDCs em ambiente 3D no grupo Sem Col III e no grupo Col III; Barras indicam o erro padrão; Grupo Sem Col III n=3 e grupo Col III n=7. 


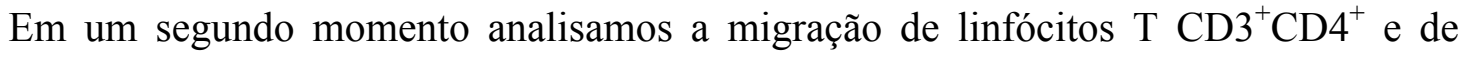
linfócitos $\mathrm{T} \mathrm{CD}^{+} \mathrm{CD}^{+}$que não tiveram nenhum contato com $\mathrm{DCs}$, em culturas onde estas estavam presentes (Figuras 33). Podemos observar que não houveram diferenças significativas na velocidade de migração de linfócitos $\mathrm{T} \mathrm{CD} 3^{+} \mathrm{CD} 4^{+}$entre grupos Sem Col e Col III (Figura 33A). Na migração de linfócitos $\mathrm{T} \mathrm{CD} 3^{+} \mathrm{CD} 8^{+}$observamos que houve um aumento na velocidade de migração desses linfócitos no grupo Col III na presença de 0 hmDCs quando comparado ao grupo Sem Col III (Figura 33B). Com relação a 2h-mDCs e 48h-mDCs a migração de linfócitos $\mathrm{T} \mathrm{CD}^{+} \mathrm{CD} 8^{+}$foi menor no grupo $\mathrm{Col}$ III do que no grupo Sem Col III (Figura 33B). Além disso, de modo geral, no grupo Sem Col III observamos um aumento na velocidade de migração de linfócitos $\mathrm{T} \mathrm{CD}^{+} \mathrm{CD}^{+}$conforme vai aumentando o estágio de maturação das DCs (Figura 33B).

A

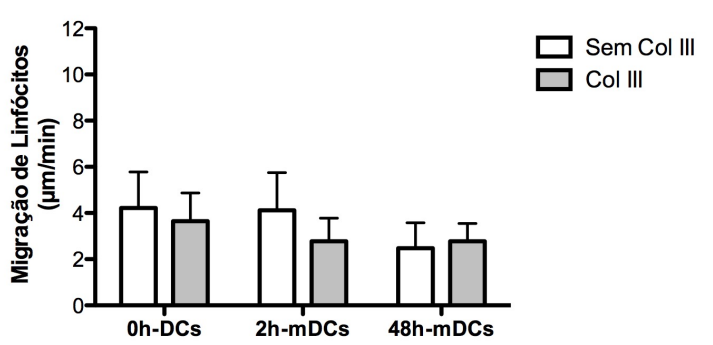

B

$\mathrm{CD}^{+}{ }^{+} \mathrm{CD} 8^{+}$

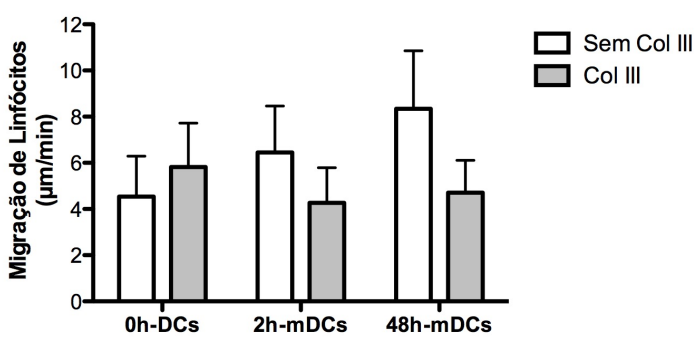

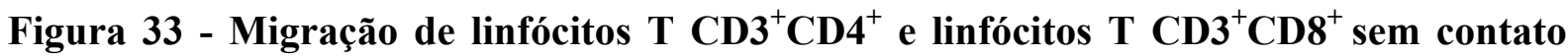
com DCs no ambiente 3D tratado com colágeno do tipo III ou não. Migração de (A) linfócitos $\mathrm{T} \mathrm{CD}^{+} \mathrm{CD}^{+} \mathrm{e}$ (B) linfócitos $\mathrm{T} \mathrm{CD}^{+}{ }^{+} \mathrm{CD} 8^{+}$nos grupos $\mathrm{Sem} \mathrm{Col}$ III e Col III; Barras indicam o erro padrão; Grupo Sem Col III $n=3$ e grupo Col III $n=7$. 
$\mathrm{Na}$ terceira etapa, observamos a velocidade de migração de $0 \mathrm{~h}-\mathrm{DCs}$, $2 \mathrm{~h}-\mathrm{mDCs}$ e $48 \mathrm{~h}-$ mDCs pré e pós interação com linfócitos $\mathrm{T} \mathrm{CD} 3{ }^{+} \mathrm{CD} 4^{+}$e linfócitos $\mathrm{T} \mathrm{CD} 3^{+} \mathrm{CD} 8^{+}$nos grupos Sem Col III e Col III (Figura 34). Na matriz 3D Biotek com colágeno, as 0h-DCs e 2h-mDCs apresentaram um leve decréscimo na velocidade de migração depois de interagir com algum linfócito $\mathrm{T} \mathrm{CD} 3^{+} \mathrm{CD} 4^{+}$. Essa velocidade de migração, porém, aumentou depois da interação com linfócitos $\mathrm{T} \mathrm{CD}^{+} \mathrm{CD}^{+}$no grupo $48 \mathrm{~h}-\mathrm{mDCs}$ (Figura 34A). Entretanto nota-se uma diferença estatisticamente significante na pré interação com linfócitos $\mathrm{T} C D 3^{+} \mathrm{CD} 4^{+}$entre o grupo 0h-DCs e o grupo 48h-mDCs onde havia a presença do colágeno III (Figura 34A). Com relação à velocidade de migração das DCs no grupo Sem Col III, observamos um aumento da velocidade das DCs depois de interagirem com linfócitos $\mathrm{T} \mathrm{CD}^{+} \mathrm{CD}^{+}$nos grupos 0 h-mDCs e 48h-mDCs e a relação interação antes/depois é igual no grupo $2 \mathrm{~h}-\mathrm{mDCs}$ (Figura 34B). Vale ainda notar que a presença do colágeno do tipo III diminuiu a velocidade de migração de 0 h-DCs e 48h-mDCs quando comparamos com as DCs cultivadas apenas na matriz 3D Biotek (Figuras 34B). Ainda no grupo Col III, 2h-mDCs apresentou uma diminuição na velocidade de migração depois de interagir com algum linfócito $\mathrm{T} \mathrm{CD} 3^{+} \mathrm{CD} 8^{+}$ (Figuras 34B). Entretanto houve um aumento na velocidade de migração depois de interagir com algum linfócito $\mathrm{T} \mathrm{CD}^{+} \mathrm{CD}^{+}$quando comparamos os grupos $48 \mathrm{~h}-\mathrm{mDCs}$ com o grupo 2h-mDCs na presença do colágeno do tipo III (Figuras 34B).

A

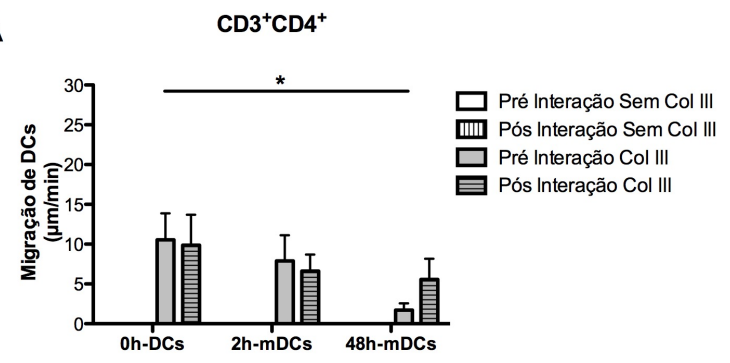

B

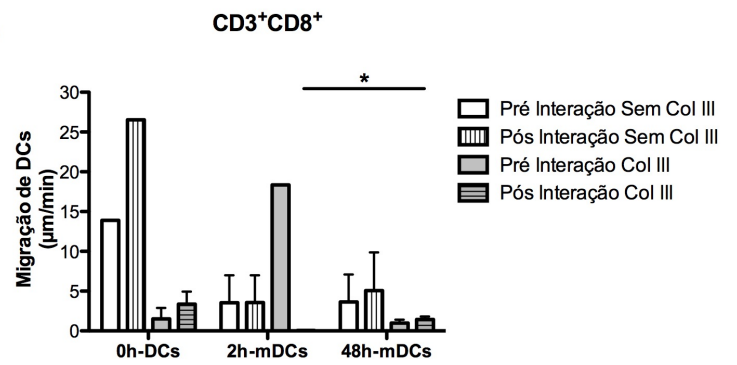

Figura 34 - Migração de DCs pré e pós interação com linfócitos T $\mathrm{CD3}^{+} \mathrm{CD4}^{+}$e linfócitos $\mathrm{T} \mathrm{CD3}^{+} \mathrm{CD8}^{+}$em um ambiente 3D tratado com colágeno tipo III ou não. (A) Migração de 0h-DCs, 2h-mDCs e 48h-mDCs nos grupos Sem Col III e Col III antes de interagirem com algum linfócito $\mathrm{T} \mathrm{CD}^{+} \mathrm{CD}^{+}$e depois de interagirem com o mesmo linfócito; (B) Migração de 0h-DCs, 2h-mDCs e 48h-mDCs nos grupos Sem Col III e Col III antes de interagirem com algum linfócito $\mathrm{T}$ $\mathrm{CD}^{+} \mathrm{CD}^{+}$e depois de interagirem com o mesmo linfócito. Barras indicam o erro padrão; (*) indica $\mathrm{p}<0,0500$; Grupo Sem Col III $n=3$ e grupo Col III $n=7$. 
$\mathrm{Na}$ última etapa, analisamos a migração de linfócitos $\mathrm{T} \mathrm{CD}^{+} \mathrm{CD} 4^{+}$e linfócitos $\mathrm{T}$ $\mathrm{CD} 3^{+} \mathrm{CD} 8^{+}$pré e pós-interação com 0h-DCs, $2 \mathrm{~h}-\mathrm{mDC}$ e e $48 \mathrm{~h}-\mathrm{mDC}$ na presença ou ausência de colágeno do tipo III (Figura 35). Nossos resultados no grupo Col III, mostraram um aumento na migração de linfócitos $\mathrm{T} \mathrm{CD}^{+} \mathrm{CD} 4^{+}$depois de interagirem com as 0h-DCs e uma diminuição na velocidade de migração pós interação nos grupos $2 \mathrm{~h}-\mathrm{mDCs}$ e $48 \mathrm{~h}-\mathrm{mDCs}$ (Figuras 35A). Vale notar que houve uma diminuição estatisticamente significante quando comparamos o grupo $2 \mathrm{~h}-\mathrm{mDC}$ e o grupo $48 \mathrm{~h}-\mathrm{mDC}$ após a interação com o linfócitos $\mathrm{T}$ $\mathrm{CD}^{+} \mathrm{CD}^{+}$(Figuras 35A). Nos grupos Sem Col III e Col III, o grupo 0h-DCs, a migração de linfócitos $\mathrm{T} \mathrm{CD}^{+} \mathrm{CD}^{+}$foi maior antes da interação celular com as DCs (Figura 35B) e no grupo 2h-mDCs migração de linfócitos $\mathrm{T} \mathrm{CD}^{+} \mathrm{CD}^{+}$foi maior depois da interação celular com as DCs ativadas por 2 horas com TNF- $\alpha$ (Figura 35B). No grupo 48h-mDCs e na presença e na ausência do colágeno do tipo III, não observamos diferenças na migração de linfócitos $\mathrm{T} \mathrm{CD}^{+} \mathrm{CD}^{+}$(Figura 35B). Entretanto houve um aumento estatisticamente significante quando comparamos o grupo 0 h-mDCs e o grupo $48 \mathrm{~h}-\mathrm{mDCs}$ após a interação com o linfócitos $\mathrm{T} \mathrm{CD}^{+} \mathrm{CD}^{+}$na presença do colágeno do tipo III (Figura 35B).

A

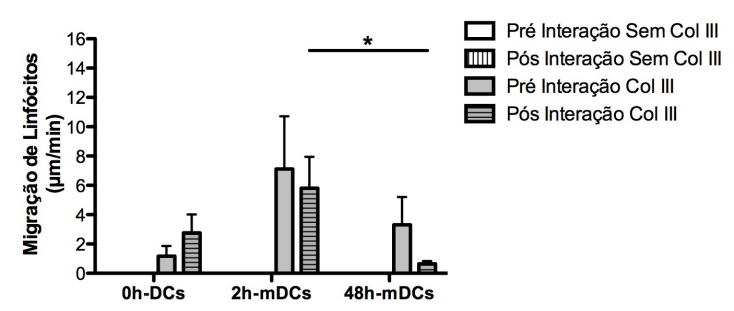

B

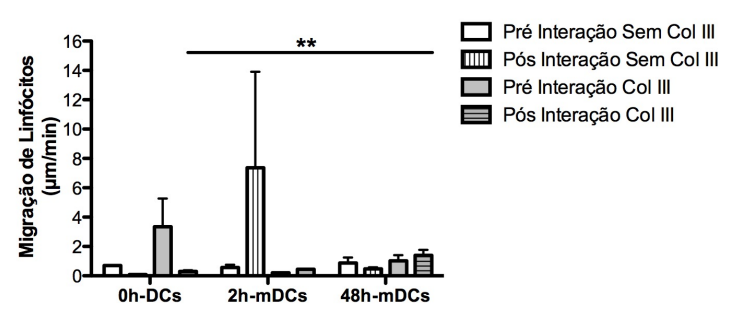

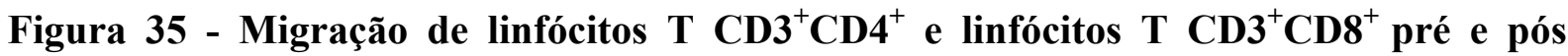
interação com DCs em um ambiente 3D tratado com colágeno tipo III ou não. (A) Migração de linfócitos $\mathrm{T} \mathrm{CD}^{+} \mathrm{CD}^{+}$nos grupos Sem Col III e Col III antes de interagirem com 0h-DCs, 2h-mDCs e 48h-mDCs e depois de interagiram com a mesma DC; (B) Migração de linfócitos $\mathrm{T} \mathrm{CD}^{+} \mathrm{CD}^{+}$nos grupos Sem Col III e Col III antes de interagirem com 0h-DCs, 2h-mDCs e 48h-mDCs e depois que interagiram com a mesma DC; Barras indicam o erro padrão; $(* *)$ indica $\mathrm{p}<0,0099,(*)$ indica $\mathrm{p}<0,0500$; Grupo Sem Col III $\mathrm{n}=3$ e grupo Col III $\mathrm{n}=7$. 
Observamos que não houveram diferenças na produção de IL-2 nos grupos 0h-DCs e 2h-mDCs tanto na presença quanto na ausência de colágeno tipo III (Figura 36A). Já o grupo 48h-mDCs apresentou um aumento na produção de IL-2 na cocultura onde havia a presença de colágeno tipo III (Figura 36A). Com relação a produção de IL-6, nos grupos Sem Col III e Col III, não foi observada a diferença dessa citocina tanto no grupo 0h-DCs quanto no grupo 48h-mDCs (Figura 36B). Em comparação, no grupo 2h-mDCs houve um aumento de IL-6 no grupo Sem Col III quando comparado no grupo Col III (Figura 36B). E ainda, no grupo $2 \mathrm{~h}$ mDCs foi observada um aumento TNF nas coculturas onde havia a presença de colágeno III quando comparada na sua ausência (Figura 36C). Porém não foram observadas diferenças dessa citocina tanto no grupo 0h-DCs quanto no grupo 48h-mDCs (Figura 36C). Foram também analisadas as citocinas IL-4, IL-10, Il-17 e IFN- $\gamma$ mas estas citocinas não foram detectadas em nossos experimentos (dados não mostrados).

A

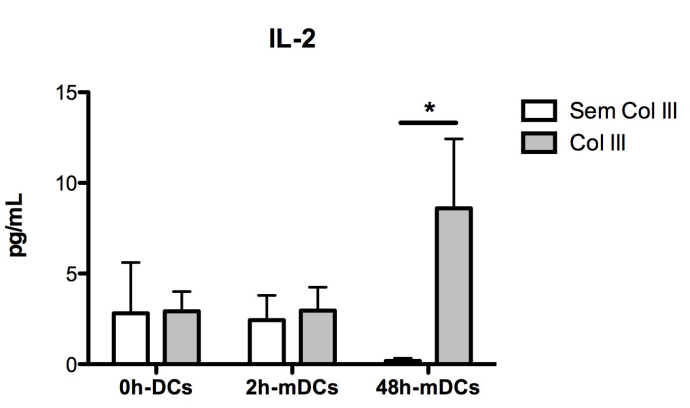

B

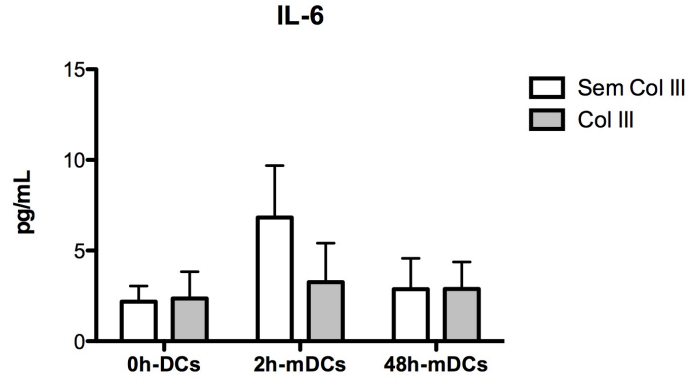

C

TNF

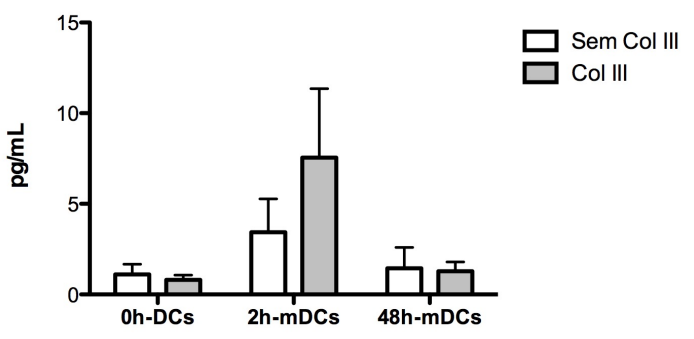

Figura 36 - Avaliação das citocinas peresentes no sobrenadante após 17 horas de cocultivo nos grupos Sem Col III e Col III. O sobrenadante após 17 horas de cocultivo entre $0 \mathrm{~h}-\mathrm{DCs}, 2 \mathrm{~h}-\mathrm{mDC}$ e $48 \mathrm{~h}-\mathrm{mDC}$ e linfócitos T dos grupos Sem Col III e Col III foram removidos da placa, centrifugados e submetidos ao processo de marcação de citocinas inflamatórias baseado na captura de beads (CBA). (A) IL-2; (B) IL-6; (C) TNF; Barras indicam o erro padrão; (*) indica $\mathrm{p}<0,0500$; Grupo Sem Col III $n=3$ e grupo Col III $n=7$. 
Por fim, verificamos o efeito aloestimulador das DCs a partir da atividade funcional das células através de seu potencial de ativar linfócitos T alogenêicos. O CTV é um corante fluorescente citoplasmático estável que é segregado igualmente entre as células filhas após a divisão celular, possibilitando a análise da proliferação celular in vitro.

A atividade aloestimuladora celular foi analisada através da proliferação de linfócitos $\mathrm{T} \mathrm{CD}^{+} \mathrm{CD}^{+} \mathrm{CD} 25^{+}$e linfócitos $\mathrm{T} \mathrm{CD}^{+} \mathrm{CD} 8^{+} \mathrm{CD} 25^{+}$, na média de três experimentos independentes, nos grupos Sem Col III e Col III (Figura 37). Nossos resultados demonstram que não houveram diferenças na porcentagem de proliferação de linfócitos $\mathrm{T}$ $\mathrm{CD} 3{ }^{+} \mathrm{CD} 4{ }^{+} \mathrm{CD} 25^{+}$nos grupos $0 \mathrm{~h}-\mathrm{DCs}$ e $2 \mathrm{~h}-\mathrm{mDCs}$ e de linfócitos $\mathrm{T} \mathrm{CD}^{+} \mathrm{CD}^{+} \mathrm{CD} 25^{+}$no grupo 2h-mDCs, tanto na presença quanto na ausência de colágeno tipo III (Figura 37A e B). Também, foi observado que houve um pequeno aumento da proliferação de linfócitos $\mathrm{T}$ $\mathrm{CD}^{+} \mathrm{CD}^{+} \mathrm{CD} 25^{+}$no grupo 0h-DCs quando comparamos o grupo Sem Col III com o grupo Col III (Figura 37B). Já na porcentagem de proliferação de linfócitos $\mathrm{T} C \mathrm{CD} 3^{+} \mathrm{CD} 4^{+} \mathrm{CD} 25^{+} \mathrm{e}$ linfócitos $\mathrm{T} \mathrm{CD}^{+} \mathrm{CD}^{+} \mathrm{CD} 25^{+}$, as $48 \mathrm{~h}-\mathrm{mDC}$ apresentaram uma tendência a aumento no grupo Col III quando comparado ao grupo Sem Col III (Figura 37A e B).

A

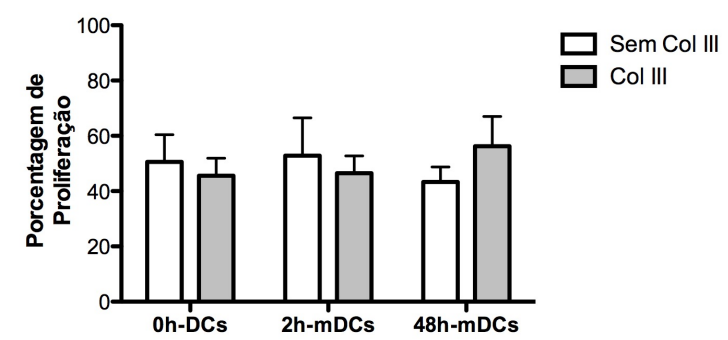

B

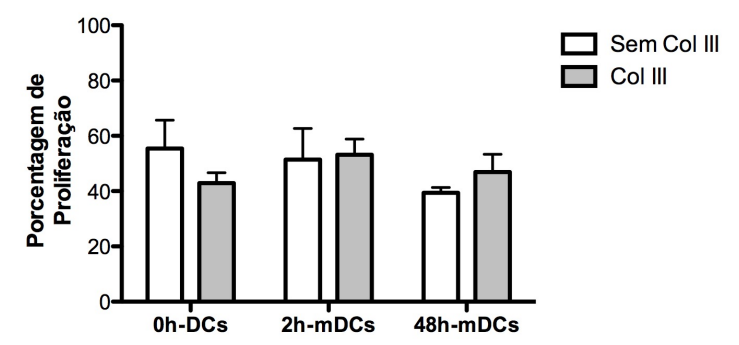

Figura 37 - Representação gráfica do resultado da diluição do CTV. Porcentagem de proliferação das subpopulações de (A) linfócitos $\mathrm{T} \mathrm{CD}^{+} \mathrm{CD} 4{ }^{+} \mathrm{CD} 25^{+}$e (B) linfócitos $\mathrm{T} \mathrm{CD}^{+} \mathrm{CD} 8{ }^{+} \mathrm{CD} 25^{+}$nos grupos Sem Col III e Col III; Barras indicam o erro padrão; Grupo Sem Col III n=3 e grupo Col III n=3.

\subsection{Caracterização das células híbridas}

Nosso próximo passo foi caracterizar as células híbridas dendríticas-tumorais, o qual realizamos imunofluorescência para essas células. Para isso, células dendríticas ativadas por 48 horas com TNF-alfa foram marcadas com anti-CD209. Esta molécula é considerada um marcador de DCs por sua elevada presença tanto em DCs imaturas como em maduras, sendo ausente em monócitos, como observado por imunofenotipagem descrita anteriormente. Já a 
linhagem de adenocarcinoma de mama SKBR-3 foi marcada com anti-Her-2/neu, gene, que codifica uma cadeia do receptor do fator de crescimento epidérmico, superexpresso em parte dos tumores epiteliais. Nossos resultados mostraram que obtivemos sucesso na fusão celular onde observamos a dupla marcação de CD209 (verde) e Her-2/neu (vermelho) (Figura 38).

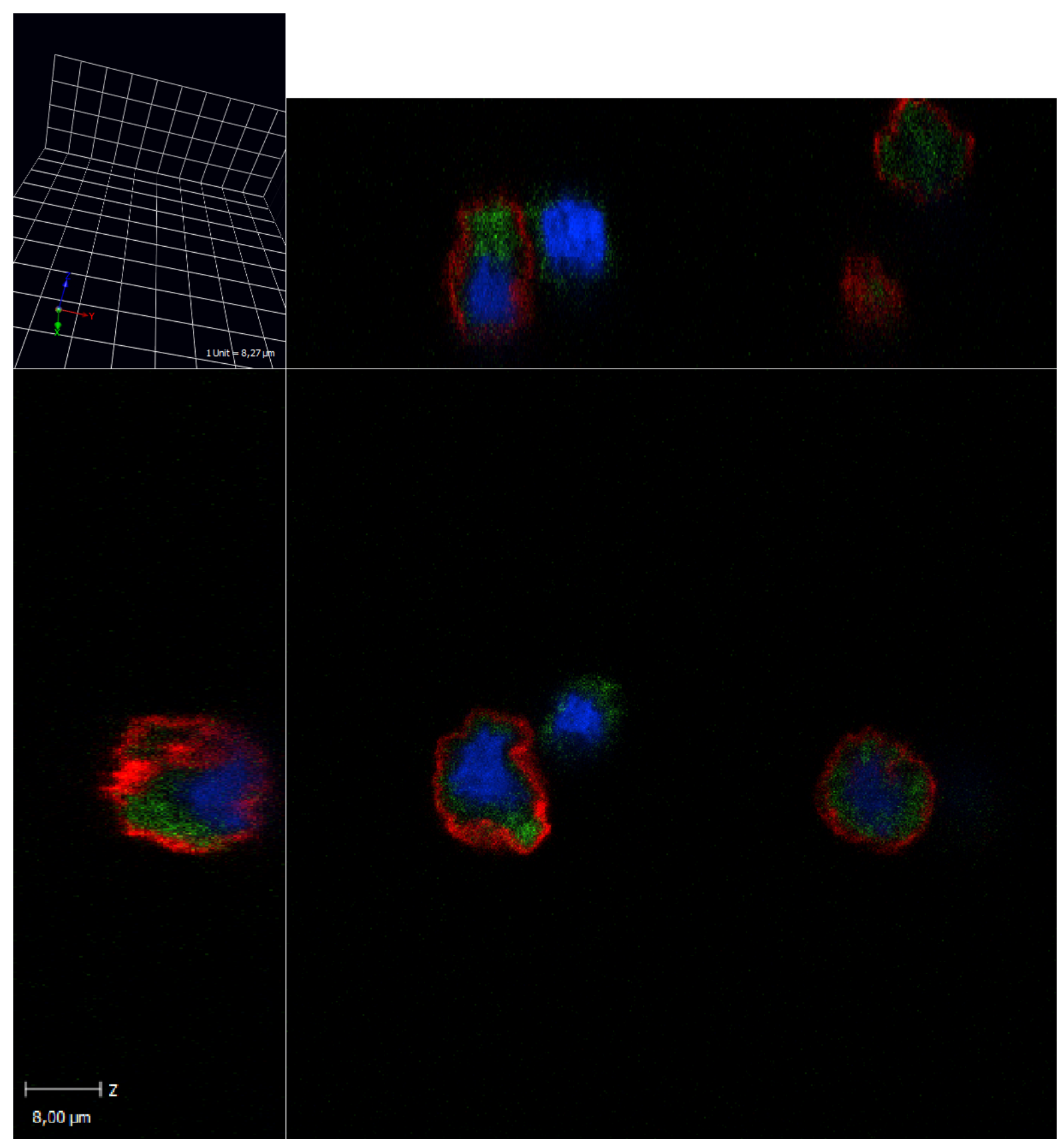

Figura 38 - Caracterização das células híbridas dendríticas-tumorais. Células 48h-mDCs foram submetidas a fusão com células da linhagem celular de adenocarcinoma de mama. Células 48h-mDCs foram marcadas com anti-CD209 (verde) e SKBR3 foram marcadas com Her-2/neu (vermelho). O núcleo das duas células foram marcados com DAP-I (azul). 


\subsection{Análise das interações entre células híbridas e linfócitos $T$ nas coculturas em ambiente 3D}

Em seguida, usando o modelo 3D Biotek tratado com o colágeno do tipo III, 48h-mDCs foram marcadas com anti-CD11c e células tumorais de pacientes com câncer de mama ou células da linhagem SKBR-3 foram marcadas com Her-2/neu e submetidas ao processo de fusão (gerando as células híbridas dendríticas-tumorais), e cocultivadas com linfócitos $\mathrm{T}$ $\mathrm{CD}^{+} \mathrm{CD}^{+}$previamente corados em CellTracker Orange e linfócitos $\mathrm{T}_{\mathrm{CD}} 3^{+} \mathrm{CD} 8^{+}$sem marcação. Como controle utilizamos apenas $48 \mathrm{~h}-\mathrm{mDCs}$ cocultivadas com as diferentes subpopulações de linfócitos T.

A primeira análise foi verificar a porcentagem de interações nos três diferentes grupos: Sem Fusão, Fusão Linhagem e Fusão Tumoral. Nós observamos que a média de interações com linfocitos $\mathrm{T} \mathrm{CD}^{+} \mathrm{CD}^{+}$nos grupos Sem Fusão, Fusão Linhagem e Fusão Tumoral foram de 18\%, 5\% e 10\%, respectivamente (Figura 39A). Com relação às interações com linfócitos $\mathrm{T} \mathrm{CD}^{+} \mathrm{CD} 8^{+}$, podemos observar que a porcentagem de interação de linfócitos $\mathrm{T} \mathrm{CD} 3^{+} \mathrm{CD} 8^{+}$ com o grupo onde as células não foram fundidas foi de $4 \%$, enquanto no grupo Fusão Tumoral, foi de 10\% (Figura 39B). Em contrapartida, o grupo Fusão Linhagem não apresentou nenhuma interação celular (Figura 39B), por isso nas análises subsequentes este grupo não será mencionado.

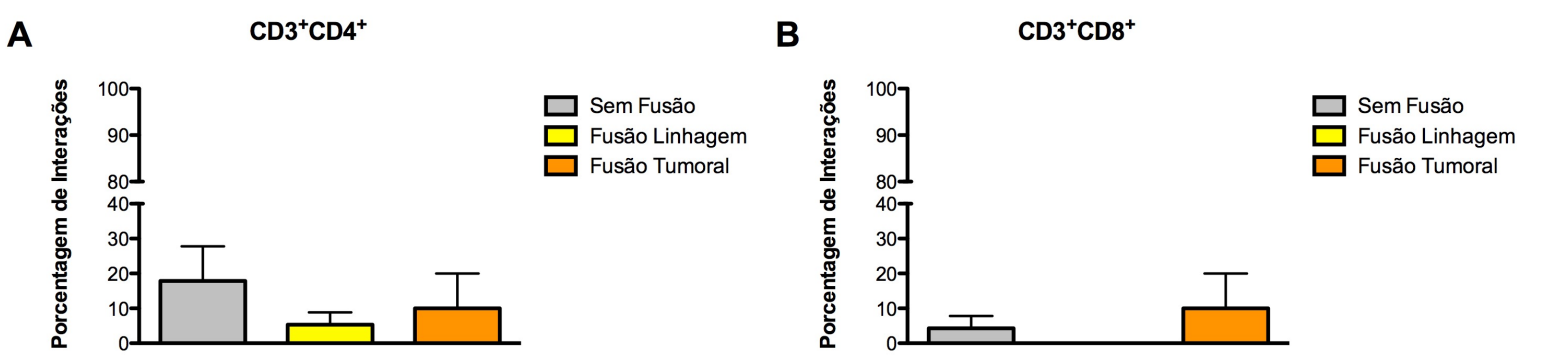

Figura 39 - Porcentagem das interações celulares em ambiente 3D. Porcentagem das interações celulares dos grupos Sem Fusão, Fusão Linhagem e Fusão tumoral com (A) linfócitos $\mathrm{T} \mathrm{CD}^{+} \mathrm{CD}^{+}$e (B) linfócitos $\mathrm{T} \mathrm{CD} 3^{+} \mathrm{CD} 8^{+}$; Barras indicam o erro padrão; Grupo Sem Fusão $n=7$, grupo Fusão Linhagem $n=3$ e grupo Fusão Tumoral $n=5$. 
A média do tempo das interações celulares foi de 42, 96 e 48 minutos, respectivamente para os grupos Sem Fusão, Fusão Linhagem e Fusão Tumoral quando interagiram com linfócitos $\mathrm{T} \mathrm{CD} 3{ }^{+} \mathrm{CD} 4^{+}$(Figura 40A) e de 40 minutos e 71 minutos respectivamente nos grupos Sem Fusão e Fusão Tumoral quando interagiram com linfócitos T $\mathrm{CD}^{+} \mathrm{CD}^{+}$(Figura 40B). Vale ressaltar que houveram diferenças estatisticamente significantes quando comparamos o grupo Fusão Linhagem com os grupos Sem Fusão e Fusão Tumoral tanto no tempo de interações desses grupos com os linfócitos $\mathrm{T} \mathrm{CD} 3^{+} \mathrm{CD} 4^{+}$ quanto com linfócitos $\mathrm{T} \mathrm{CD} 3^{+} \mathrm{CD} 8^{+}$.

A

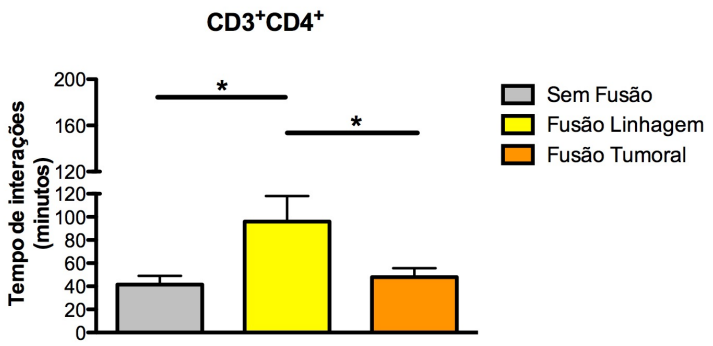

B

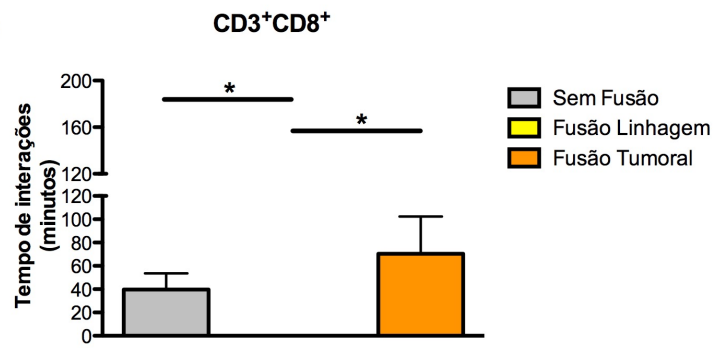

Figura 40 - Tempo de interação celular no ambiente 3D Biotek nos grupos Sem Fusão, Fusão Linhagem e Fusão Tumoral. Tempo de interações celulares dos grupos Sem Fusão, Fusão Linhagem e Fusão tumoral com (A) linfócitos T $\mathrm{CD}^{+} \mathrm{CD}^{+} \mathrm{e}$ (B) linfócitos $\mathrm{T} \mathrm{CD} 3^{+} \mathrm{CD}^{+}$; Barras indicam o erro padrão; (*) indica $\mathrm{p}<0,0500$; Grupo Sem Fusão n=7, grupo Fusão Linhagem n=3 e grupo Fusão Tumoral n=5.

Além disso, quando comparados os tipos de interações celulares, observamos que no grupo Sem Fusão as 48h-mDCs interagiram predominantemente com os mesmos linfócitos $\mathrm{T}$ $\mathrm{CD}^{+} \mathrm{CD}^{+}$repetidas vezes (Tabela 9). Nos grupos Sem Fusão e Fusão Linhagem houve uma distribuição heterogênea dos tipos de interação, com prevalência de interações com um único linfócito $\mathrm{T} \mathrm{CD}^{+} \mathrm{CD}^{+}$com $48 \mathrm{~h}-\mathrm{mDCs}$ e células híbridas dendríticas-tumorais, respectivamente (Tabela 9). Já no grupo Fusão Tumoral observamos uma preferencia células híbridas dendríticas-tumorais interagindo com mais de 2 linfócito $\mathrm{T} \mathrm{CD}^{+} \mathrm{CD}^{+}$diferentes (Tabela 9). Metade das células híbridas dendríticas-tumorais do grupo Fusão Tumoral interagiram com um único linfócito $\mathrm{T} \mathrm{CD}^{+}{ }^{+} \mathrm{CD} 8^{+}$e a outra metade interagiu com mais de 2 linfócitos $\mathrm{T} \mathrm{CD}^{+} \mathrm{CD}^{+}$sendo que com algum desses linfócitos, mais de uma vez (Tabela 9). 
Tabela 9 - Porcentagem dos diferentes tipos de interações celulares dos linfócitos T $\mathrm{CD3}^{+} \mathrm{CD}^{+}$e linfócitos $\mathrm{T} \mathrm{CD3}^{+} \mathrm{CD8}^{+}$nos grupos Sem Fusão, Fusão Linhagem e Fusão Tumoral.

\begin{tabular}{|c|c|c|c|c|c|c|}
\hline & \multicolumn{2}{|c|}{ Sem Fusão } & \multicolumn{2}{|c|}{ Fusão Linhagem } & \multicolumn{2}{|c|}{$\begin{array}{c}\text { Fusão } \\
\text { Tumoral }\end{array}$} \\
\hline & $\mathrm{CD4}^{+}$ & $\mathrm{CD8}^{+}$ & $\mathrm{CD4}^{+}$ & $\mathrm{CD8}^{+}$ & $\mathrm{CD}^{+}$ & $\mathrm{CD8}^{+}$ \\
\hline $\begin{array}{l}\text { a) } 48 \mathrm{~h}-\mathrm{mDCs} \text { ou células híbridas } \\
\text { interagindo com apenas } 1 \text { linfócito }\end{array}$ & $50 \%$ & - & $75 \%$ & - & - & $50 \%$ \\
\hline $\begin{array}{l}\text { b) } 48 \mathrm{~h}-\mathrm{mDCs} \text { ou células híbridas } \\
\text { interagindo com o mesmo linfócito } \\
\text { repetidas vezes }\end{array}$ & $16,6 \%$ & $100 \%$ & $8 \%$ & - & - & - \\
\hline $\begin{array}{l}\text { c) } 48 \mathrm{~h}-\mathrm{mDCs} \text { ou células híbridas } \\
\text { interagindo com mais de } 2 \text { linfócitos } \\
\text { diferentes }\end{array}$ & $33,4 \%$ & - & $17 \%$ & - & $100 \%$ & $50 \%$ \\
\hline $\begin{array}{l}\text { d) } 48 \mathrm{~h}-\mathrm{mDCs} \text { ou células híbridas } \\
\text { interagindo com mais de } 2 \text { linfócitos } \\
\text { sendo que com algum desses linfócitos, } \\
\text { mais de uma vez }\end{array}$ & - & - & - & - & - & - \\
\hline
\end{tabular}

(-) sem interação celular observada

Em seguida, analisamos a velocidade de migração das DCs ou células fundidas e dos linfócitos T. Primeiramente observamos a velocidade de migração das DCs ou células fundidas no ambiente 3D Biotek com colágeno do tipo III e que não interagiram com linfócitos T (Figura 41). Nossos resultados mostraram que a média da migração de 48hmDCs no grupo Sem Fusão foi estatisticamente mais rápido (10 $\mu \mathrm{m} /$ minuto) quando comparamos com a média da migração das células fundidas nos grupos Fusão Linhagem (5 $\mu \mathrm{m} /$ minuto) e Fusão Tumoral (3 $\mu \mathrm{m} /$ minuto) (Figura 41).

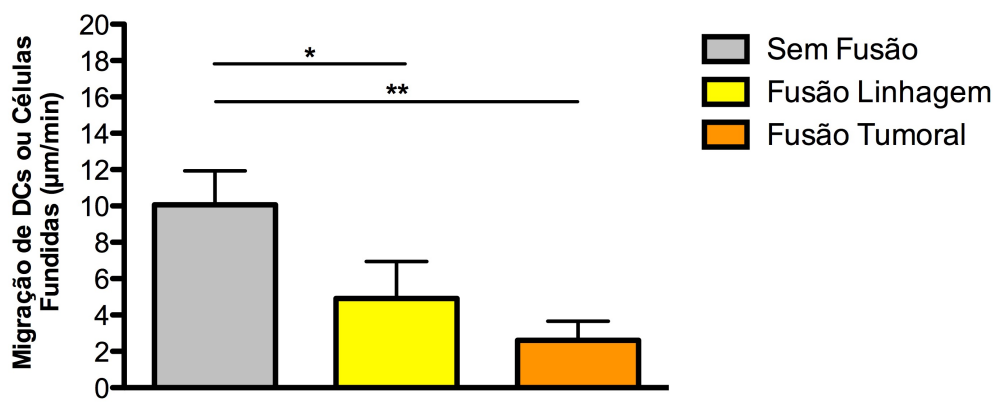

Figura 41 - Migração de DCs ou células fundidas sem contato com nenhum linfócito T nos grupos Sem Fusão, Fusão Linhagem e Fusão Tumoral. Migração de células 48h-mDCs (Sem Fusão), 48h-mDCs fundidas com SKBR-3 (Fusão Linhagem) e 48h-mDCs fundidas com células tumorais de pacientes (Fusão Tumoral) em ambiente 3D na presença de colágeno do tipo III; Barras indicam o erro padrão; $(* *)$ indica $p<0,0099,(*)$ indica $p<0,0500$; Grupo Sem Fusão n=7, grupo Fusão Linhagem $n=3$ e grupo Fusão Tumoral n=5. 
Logo após, analisamos a migração de linfócitos $\mathrm{T} \mathrm{CD}^{+} \mathrm{CD}^{+}$e de linfócitos $\mathrm{T}$ $\mathrm{CD}^{+} \mathrm{CD}^{+}$que não tiveram nenhum contato com DCs ou células fundidas, em culturas onde estas estavam presentes (Figuras 42). Podemos observar que a velocidade de migração de linfócitos $\mathrm{T} \mathrm{CD}^{+} \mathrm{CD}^{+}$nos grupos Sem Fusão foi de $3 \mu \mathrm{m} /$ minuto e que a velocidade de migração de linfócitos $\mathrm{T} \mathrm{CD}^{+} \mathrm{CD}^{+}$no grupo Fusão Linhagem $(5 \mu \mathrm{m} /$ minuto) foi estatisticamente maior quando o comparamos com o grupo Fusão Tumoral $(0,80 \mu \mathrm{m} / \mathrm{minuto})$ (Figura 42A). Já a velocidade de migração dos linfócitos $\mathrm{T} \mathrm{CD}^{+} \mathrm{CD}^{+}$foi $4,5 \mu \mathrm{m} /$ minuto no grupo Sem Fusão, $5 \mu \mathrm{m} /$ minuto no grupo Fusão Linhagem e $3 \mu \mathrm{m} /$ minuto no grupo Fusão Tumoral (Figura 42B).

A

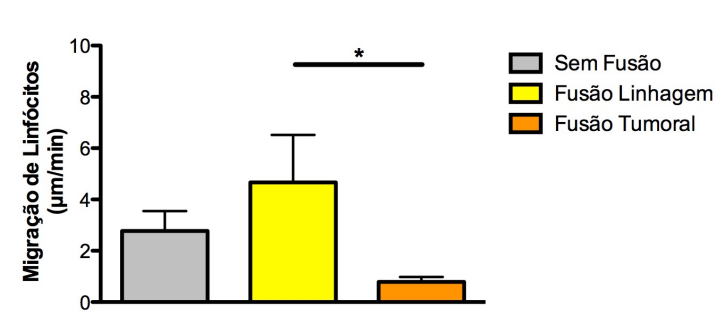

B

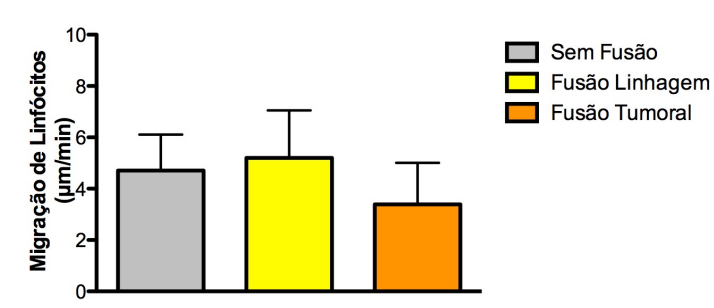

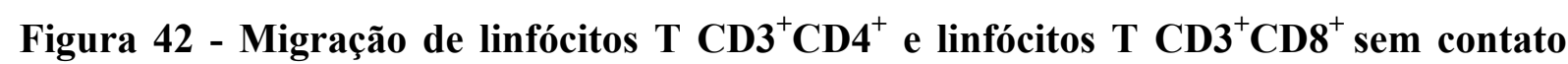
com DCs nos grupos Sem Fusão, Fusão Linhagem e Fusão Tumoral. Migração de (A) linfócitos $\mathrm{T} \mathrm{CD} 3^{+} \mathrm{CD} 4^{+}$e (B) linfócitos $\mathrm{T} \mathrm{CD} 3^{+} \mathrm{CD} 8^{+}$que não tiveram nenhum tipo de contato com DCs ou células híbridas dos grupos Sem Fusão, Fusão Linhagem e Fusão Tumoral; Barras indicam o erro padrão; (**) indica $\mathrm{p}<0,0099$, $(*)$ indica $\mathrm{p}<0,0500$; Grupo Sem Fusão $n=7$, grupo Fusão Linhagem $n=3$ e grupo Fusão Tumoral n=5. 
Na próxima etapa, observamos a velocidade de migração de DCs ou células fundidas pré e pós interação com linfócitos $\mathrm{T} C D 3^{+} \mathrm{CD} 4^{+}$e linfócitos $\mathrm{T} \mathrm{CD} 3^{+} \mathrm{CD} 8^{+}$nos grupos Sem Fusão, Fusão Linhagem e Fusão Tumoral (Figura 43). Podemos observar que houve uma diminuição estatisticamente significante quando comparamos pré interação das $48 \mathrm{~h}-\mathrm{mDCs}$ com a pré interação das células fundidas do grupo Fusão Linhagem (Figura 43A). Nota-se um aumento estatisticamente significante pós interação das células fundidas do grupo Fusão Linhagem quando comparado a pré interação do mesmo linfócitos $\mathrm{T} \mathrm{CD}^{+} \mathrm{CD}^{+}$(Figura 43A). A migração das células fundidas antes de interagirem com um linfócitos $\mathrm{T} \mathrm{CD} 3^{+} \mathrm{CD} 4^{+}$ do grupo Fusão Linhagem migraram estatisticamente mais de devagar quando comparamos com as migração das células fundidas antes de interagirem com um linfócitos $\mathrm{T} \mathrm{CD} 3^{+} \mathrm{CD} 4^{+}$ do grupo Fusão Tumoral (Figura 43A). Também observamos que houve um aumento da velocidade de migração das 48h-mDCs e das células fundidas após interagiram com um linfócito $\mathrm{T} \mathrm{CD}^{+} \mathrm{CD}^{+}$quando comparado antes da interação (Figura 43A). Além disso, de forma geral, observamos que tanto as $48 \mathrm{~h}-\mathrm{mDC}$ quanto as células fundidas de todos os três grupos migraram mais rápido quando interagiram com linfócitos $\mathrm{T} \mathrm{CD} 3^{+} \mathrm{CD} 4^{+}$do que quando interagiram com linfócitos $\mathrm{T} \mathrm{CD}^{+} \mathrm{CD}^{+}$(Figura 43A e B). A velocidade de migração das 48h-mDCs no grupo Sem Fusão pós interação com linfócitos $\mathrm{T} \mathrm{CD}^{+} \mathrm{CD}^{+}$foi estatisticamente mais rápida do que a velocidade de migração das células fundidas nos grupo Fusão Linhagem pós interação com linfócitos $\mathrm{T} \mathrm{CD}^{+} \mathrm{CD}^{+}$(Figura 43B). A relação interação pré/pós foi igual no grupo Fusão Tumoral (Figura 43B).

A

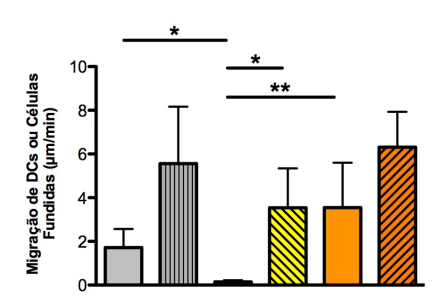

B

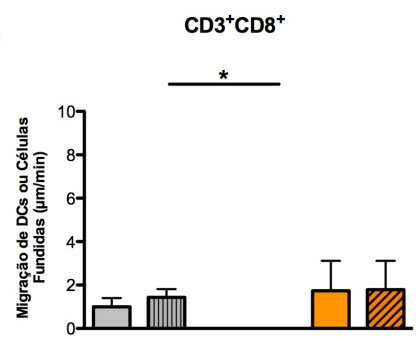

$\square$ Pré Interação Sem Fusão

Pós Interação Sem Fusão

Pré Interação Fusão Linhagem

Pós Interação Fusão Linhagem

Pré Interação Fusão Tumoral

Pós Interação Fusão Tumoral

Figura 43 - Migração de DCs ou células fundidas pré e pós interação com linfócitos T $\mathrm{CD3}^{+} \mathrm{CD4}^{+}$e linfócitos $\mathrm{T} \mathrm{CD3}^{+} \mathrm{CD8}^{+}$nos grupos Sem Fusão, Fusão Linhagem e Fusão Tumoral. Migração celular de DCs ou células fundidas antes e depois de interagirem com (A) linfócitos $\mathrm{T} \mathrm{CD}^{+} \mathrm{CD}^{+}$e (B) linfócitos $\mathrm{T}$ $\mathrm{CD} 3^{+} \mathrm{CD} 8^{+}$nos grupos Sem Fusão, Fusão Linhagem e Fusão Tumoral; Barras indicam o erro padrão; (**) indica $\mathrm{p}<0,0099,(*)$ indica $\mathrm{p}<0,0500$; Grupo Sem Fusão $n=7$, grupo Fusão Linhagem $n=3$ e grupo Fusão Tumoral n=5. 
$\mathrm{Na}$ última etapa da análise de migração, analisamos a migração de linfócitos $\mathrm{T}$ $\mathrm{CD}^{+} \mathrm{CD}^{+}$e linfócitos $\mathrm{T} \mathrm{CD} 3^{+} \mathrm{CD} 8^{+}$pré e pós interação com DCs ou células fundidas nos grupos Sem Fusão, Fusão Linhagem e Fusão Tumoral (Figura 44). Nossos resultados mostraram a diminuição da velocidade de migração dos linfócitos $\mathrm{T}_{\mathrm{CD}}{ }^{+} \mathrm{CD}^{+}$no grupo Sem Fusão após a interação com o mesmo linfócito (Figura 44A). No grupo Fusão Linhagem não observamos diferenças na migração de linfócitos $\mathrm{T} \mathrm{CD}^{+} \mathrm{CD}^{+}$pré/pós interação celular (Figura 44A). Entretanto, no grupo e Fusão Tumoral observamos um aumento estatisticamente significante da pós interação comparado com a pré interação com linfócitos $\mathrm{T}$ $\mathrm{CD}^{+} \mathrm{CD}^{+}$(Figura 44A). O grupo Sem Fusão também não apresentou diferenças na velocidade de migração de linfócitos $\mathrm{T} C D 3^{+} \mathrm{CD} 8^{+}$pré/pós interação celular porém esta pré interação foi estatisticamente maior quando comparamos com a pré interação das células fundidas do grupo Fusão Linhagem (Figura 44B). Houve um aumento estatisticamente significante quando comparamos a pós interação do grupo do grupo Sem Fusão com a pós interação dos grupos Fusão Linhagem e Fusão Tumoral (Figura 44B). Também observamos que houve um aumento estatisticamente significante entre a pós interação do grupos Fusão Linhagem e Fusão Tumoral (Figura 44B). Já a velocidade de migração dos linfócitos $\mathrm{T}$ $\mathrm{CD}^{+} \mathrm{CD}^{+}$no grupo Fusão Tumoral apresentou uma diminuição da velocidade de migração após a interação com o mesmo linfócito (Figura 44B).

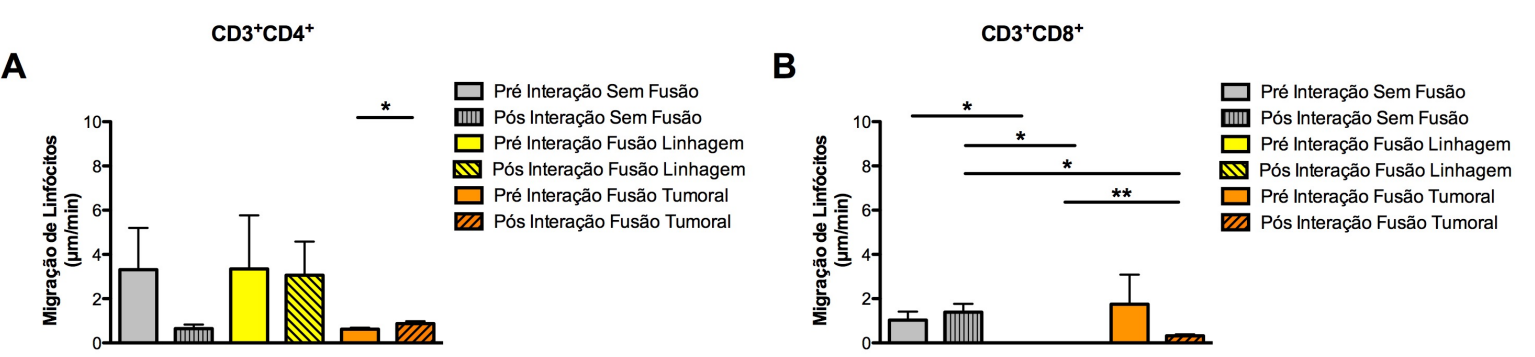

Figura 44 - Migração de linfócitos $\mathrm{T} \mathrm{CD3}^{+} \mathrm{CD4}^{+}$e linfócitos $\mathrm{T} \mathrm{CD3}^{+} \mathrm{CD8}^{+}$pré e pós interação com as DCs ou células fundidas nos grupos Sem Fusão, Fusão Linhagem e Fusão Tumoral. Migração (A) linfócitos $\mathrm{T} \mathrm{CD}^{+} \mathrm{CD}^{+}$e (B) linfócitos $\mathrm{T} \mathrm{CD}^{+} \mathrm{CD}^{+}$antes e depois de interagirem com DCs ou células fundidas nos grupos Sem Fusão, Fusão Linhagem e Fusão Tumoral; Barras indicam o erro padrão; $(* *)$ indica $p<0,0099,(*)$ indica $p<0,0500$; Grupo Sem Fusão $n=7$, grupo Fusão Linhagem $n=3$ e grupo Fusão Tumoral n=5. 


\subsubsection{Análises funcionais entre células hibridas e linfócitos $T$ nas coculturas em ambiente $\underline{3 D}$}

Após a análise das migrações celulares novamente, verificamos o padrão de citocinas presente nas coculturas. Assim, observamos uma diferença estatisticamente significante entre os grupos Sem Fusão e Fusão Tumoral (Figura 45A). Com relação a produção de IL-6, houve um aumento da citocina no grupo Fusão Linhagem e uma diminuição no grupo Fusão Tumoral quando comparados com o grupo Sem Fusão (Figura 45B). E ainda, não foram observadas diferenças de TNF nos três grupos analisados (Figura 45C). Foram também analisadas as citocinas IL-4, IL-10, Il-17 e IFN- $\gamma$ e novamente não foram detectadas em nossos experimentos (dados não mostrados).

A

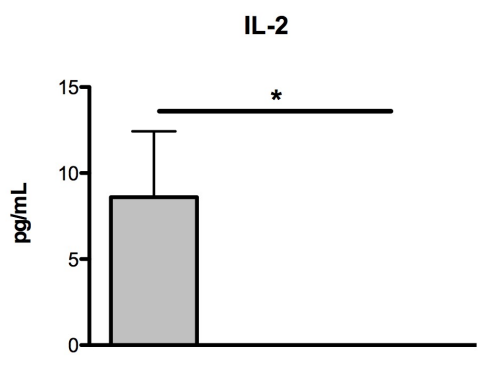

B

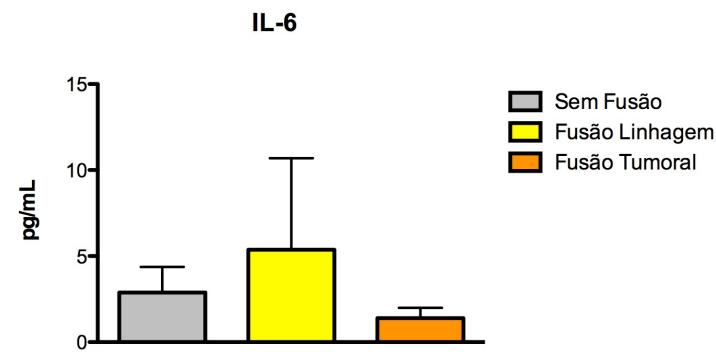

C

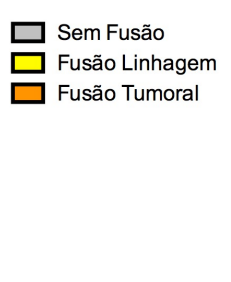

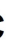

TNF

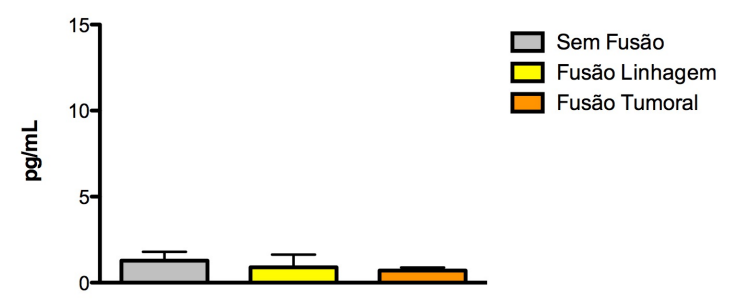

Figura 45 - Avaliação das citocinas peresentes no sobrenadante após 17 horas de cocultivo nos grupos Sem Fusão, Fusão Linhagem e Fusão Tumoral. O sobrenadante após 17 horas de cocultivo dos grupos Sem Fusão, Fusão Linhagem e Fusão Tumoral foram removidos da placa, centrifugados e submetidos ao processo de marcação de citocinas inflamatórias baseado na captura de beads (CBA). (A) IL-2; (B) IL-6; (C) TNF; Barras indicam o erro padrão; (*) indica $\mathrm{p}<0,0500$; Grupo Sem Fusão $n=7$, grupo Fusão Linhagem $\mathrm{n}=3$ e grupo Fusão Tumoral $\mathrm{n}=5$. 
Por fim, fomos verificar o efeito estimulador das DCs e das células híbridas através de seu potencial de ativar linfócitos T. A atividade estimuladora novamente foi analisada através da proliferação de linfócitos $\mathrm{T}$ CD $3{ }^{+} \mathrm{CD} 4{ }^{+} \mathrm{CD} 25^{+}$e linfócitos $\mathrm{T}$ CD $3{ }^{+} \mathrm{CD} 8^{+} \mathrm{CD} 25$ porém nos grupos Sem Fusão e Fusão Tumoral (Figura 46). Nossos resultados demonstram que houve uma diminuição estatisticamente significante na porcentagem de proliferação de linfócitos $T$ $\mathrm{CD}^{+} \mathrm{CD}^{+} \mathrm{CD} 25^{+}$e de linfócitos $\mathrm{T} \mathrm{CD}^{+} \mathrm{CD}^{+} \mathrm{CD} 25^{+}$quando comparamos efeito estimulador das DCs com o efeito estimulador das células híbridas ambos cocultivados em ambiente 3D (Figura 46A e B).

A

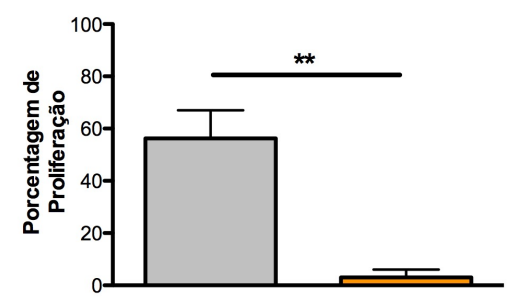

B

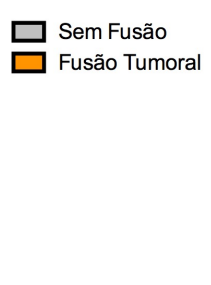

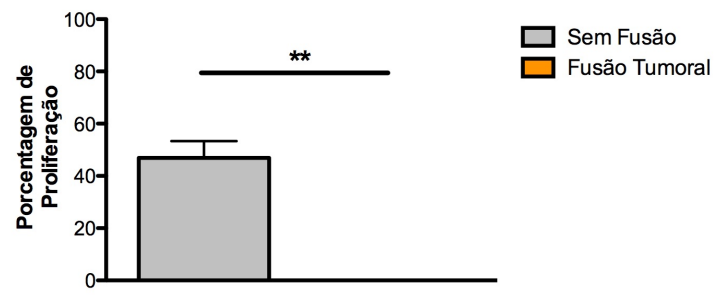

Figura 46 - Representação gráfica do resultado da diluição do CTV. (A) Porcentagem de proliferação das subpopulações de (A) linfócitos $\mathrm{T}$ CD $3^{+} \mathrm{CD} 4^{+} \mathrm{CD} 25^{+}$e (B) linfócitos $\mathrm{T} \mathrm{CD}^{+} \mathrm{CD}^{+} \mathrm{CD} 25^{+}$nos grupos Sem Fusão e Fusão Tumoral; Barras indicam o erro padrão; $(* *)$ indica $\mathrm{p}<0,0099,(*)$ indica $\mathrm{p}<0,0500$; Grupo Sem Fusão n=3 e grupo Fusão Tumoral n=3. 


\section{DISCUSSÃO}

Neste estudo, procuramos estabelecer um modelo que permita estudar interações celulares em ambiente 3D entre células híbridas dendríticas-tumorais e linfócitos T. Este tipo de estudo poderia contribuir para o aperfeiçoamento de estratégias imunoterapêuticas contra o câncer de mama, baseadas em protocolos anteriores que vem utilizando a imunoterapia com células híbridas (BARBUTO et al., 2004; NEVES et al., 2005; PINHO et al., Submetido). Embora com resultados promissores, tais estratégias ainda necessitam ser melhor caracterizadas, o comportamento e as funções desempenhadas por essas células híbridas dendríticas-tumorais que, insuficientemente conhecidos, impedem que se atinja seu completo potencial e requerem portanto o desenvolvimento de novos métodos de análise.

Inicialmente, determinamos que as células $\mathrm{CD} 14^{+}$, linfócitos $\mathrm{T} \mathrm{CD}^{+}$ou linfócitos $\mathrm{T}$ $\mathrm{CD}^{+} \mathrm{CD}^{+}$isoladas apresentaram um alto índice de pureza $( \pm 90 \%)$. A única população celular com pureza abaixo da esperada $( \pm 60 \%)$ foi a de linfócitos $\mathrm{T} \mathrm{CD}^{+} \mathrm{CD}^{+}$. Acreditamos que o fato dessas células terem passado por três isolamentos sucessivos em coluna imunomagnética possa ter afetado a expressão/detecção da molécula CD8 na membrana.

Após o isolamento de monócitos $\mathrm{CD} 14^{+}$, avaliamos se a diferenciação em DCs e sua maturação foi satisfatória, utilizando métodos padronizados e descritos pelo nosso grupo anteriormente (AZEVEDO et al., 2007; BARBUTO et al., 2004; NEVES et al., 2005; RAMOS et al., 2012). A morfologia encontrada foi a esperada e já descrita na literatura (STEINMAN; COHN, 1973; VAN VOORHIS et al., 1982). Fenotipicamente, ocorreu diminuição gradativa da expressão da molécula CD14 com o decorrer da diferenciação e maturação das DCs, conforme o esperado (KIERTSCHER; ROTH, 1996; SALLUSTO; LANZAVECCHIA, 1994). Outros marcadores, como as moléculas coestimuladoras de linfócitos T (CD40, CD80 e CD86), também aumentaram com a diferenciação e maturação, de modo condizente com seus papéis fisiológicos (BANCHEREAU et al., 2000; CAUX et al., 1994; KIERTSCHER; ROTH, 1996). CD83 também foi mais expresso no grupo 48h-mDCs. Esse indicador da maturação das DCs (ZHOU; TEDDER, 1996) parece estar diretamente envolvido na ativação de linfócitos $\mathrm{T} \mathrm{CD}^{+} \mathrm{CD} 4^{+}$e linfócitos $\mathrm{T} \mathrm{CD}^{+} \mathrm{CD}^{+}$(HIRANO et al., 2006; LECHMANN et al., 2001; PINHO et al., 2014). Com relação à molécula de superfície CD1a, expressa em DCs e que participa da apresentação de lipídeos e glicolipídeos para os linfócitos T (AQUINO et al., 2011), encontrou-se pouca variação entre os grupos de DCs, sendo esta molécula praticamente ausente em monócitos. Entretanto, entre os diferentes doadores, obtivemos variação muito grande de expressão de CD1a, o que não corresponde ao 
descrito por outros autores (CAO et al., 2002). Por outro lado, nossos achados quanto à expressão de CD209, molécula envolvida em diversas funções imunoreguladoras (ZHOU et al., 2006) e que foi altamente expresso nos grupos de DCs e ausente em monócitos, são coerentes com a literatura, que descreve altos níveis desta molécula em DCs imaturas e maduras (GEIJTENBEEK et al., 2000). Já o receptor de quimiocinas CCR7, importante na migração das DCs para os linfonodos, só foi encontrado em monócitos, algo já descrito na literatura (CÔTÉ et al., 2009), embora não sendo o senso comum (SAEKI et al., 1999; YANAGIHARA et al., 1998). Uma possível explicação para a baixa expressão do CCR7 em 48h-mDCs pode depender do ativador usado, pois há dados na literatura (e de nosso laboratório), que indicam que sua expressão em DCs maduras está relacionada à ativação com lipopolissacarídeo (YANAGIHARA et al., 1998). Por fim, analisamos a molécula de superfície PD-L1, outro importante marcador funcional das DCs. Wölfle et al. (2011) mostraram que a expressão de PD-L1 por DCs está associada a um perfil tolerogênico, pois DCs que a expressam, induzem linfócitos $\mathrm{T} C D 4^{+} \mathrm{CD} 25^{+} \mathrm{FOXP}^{+}$a suprimir a proliferação linfocitária. Porém, as alterações já relatadas em teses e trabalhos do nosso grupo mostraram que a expressão de PD-L1 acompanhando a de CD86 pode ser muito mais uma regulação da ativação, do que um mecanismo somente de indução de tolerância. Em suma, nossos resultados mostram que a diferenciação e maturação das DCs foi eficaz, observando-se a diminuição de CD14, o aumento das moléculas coestimulatórias CD40, CD80 e CD86, de CD83, assim como a alta expressão de CD209 e PD-L1 após estes processos. Vale notar que o grupo $2 \mathrm{~h}-\mathrm{mDCs}$ possui perfis morfológico e fenotípico muito mais parecidos com $0 \mathrm{~h}-\mathrm{DCs}$ do que com 48h-mDCs, parecendo situar-se entre DCs imaturas e maduras. É ainda interessante reparar nas significantes variações entre os doadores, condizentes com a heterogeneidade que há na raça humana, e para a qual ainda contribui o dimorfismo sexual apresentado pelo sistema imune (HUGHES; CLARK, 2007), uma vez que nossos doadores de sangue foram tanto homens, quanto mulheres.

Após a caracterização das células, nosso próximo passo foi a escolha da melhor forma de análise das interações e migração de células, como publicado anteriormente por nosso grupo (STEPONAVICIUS-CRUZ; FREITAS; BARBUTO, 2013). Assim, a matriz 3D Biotek foi a escolhida como arcabouço, pois além de permitir marcação suficiente das células, este material tem ainda a vantagem de ser amplamente utilizado na comunidade científica, permitindo comparação melhor de nossos resultados. Em nosso caso, obtivemos mais interações de DCs maduras com linfócitos $\mathrm{T} \mathrm{CD}^{+}$utilizando essa metodologia (STEPONAVICIUS-CRUZ; FREITAS; BARBUTO, 2013), o que pode ser explicado pelo 
fato desta matriz possuir uma forma reticular tridimensional, lembrando o arcabouço constituinte de um linfonodo.

O próximo passo foi adicionar mais uma variável ao experimento, com a adição de componentes da matriz extracelular. A literatura apresenta vários trabalhos utilizando o colágeno tipo I e o Matrigel como substratos para os experimentos de interação entre linfócitos e DCs, mas as concentrações desses substratos foram muito variáveis (FRIEDL; BROCKER, 2004; GUNZER et al., 2000a,b; ILINA et al., 2011; SIXTS; LAMMERMANN, 2011) e nenhum deles levou em consideração que o colágeno tipo III é o substrato predominante nos linfonodos (KRAMER; ROSEN; MECDONALD, 1988). Nosso grupo é pioneiro na utilização do colágeno III como substrato de coculturas 3D. Em nossos resultados, esse substrato mostrou melhores taxas de migração de DCs maduras sem contato com linfócitos e após interagir com os mesmos, quando comparados a outros substratos. Além disso, o uso de colágeno III mostrou melhores resultados de porcentagem de interação, tipos de interação e produção de citocinas do que quando nenhum substrato foi utilizado ou quando uma mistura de colágenos I, III e Matrigel foi utilizada (STEPONAVICIUS-CRUZ et al., Submetido). Estes resultados corroboram a literatura, visto que a decisão final de uma célula para exercer diversas funções é resultado de uma resposta bem coordenada de sua interação com os componentes da MEC e com as células vizinhas (SCHMIDT; FRIEDL, 2010; SCHUPPAN; RÜHL, 1994; STERN et al., 2009). No entanto, os mecanismos exatos de como a MEC desempenha tais funções permanece indefinido, mas existem fortes evidências de que a MEC influencia as características celulares por mudanças na organização tridimensional do citoesqueleto e ativação de segundo mensageiro e via da proteína quinase (ADAMS; WATT, 1993; FENG; CHENG; CHAO, 2013; INGBER et al., 1994; ROSKELLEY; DESPREZ; BISSELL, 1994).

De modo geral, DCs imaturas localizadas em órgãos não linfoides com matriz extracelular de composição variável estão principalmente envolvidas na captura e no processamento dos antígenos; quando ocorrem perturbações na homeostasia, estas células imaturas migram para órgãos linfoides, como os linfonodos, através do fluxo linfático. Durante este processo, as células dendríticas amadurecem tornando-se as principais APCs na ativação de linfócitos T "naïve” (BANCHEREAU; STEINMAN, 1998; BANCHEREAU et al., 2000; GUERMONPREZ et al., 2002). Neste linfonodo, encontramos fibras colágenas reticulares muito delgadas constituídas predominantemente pelo colágeno do tipo III (CASTAÑOS-VELEZ; BIBERFELD; PATARROYO, 1995; KARTTUNEN et al., 1989; KRAMER; ROSEN; MECDONALD, 1988; SOBOCINSKI et al., 2010; WILLARD-MACK, 
2006), um fator importante a ser considerado e que ajudou a decisão de realizar os experimentos seguintes na presença deste substrato.

Nos experimentos subsequentes, a matriz 3D tratada com colágeno do tipo III permitiu interações entre DCs em diferentes estágios de maturação com linfócitos $\mathrm{T} \mathrm{CD} 3^{+} \mathrm{CD} 4^{+}$, mas na ausência de colágeno do tipo III, não observamos nenhuma interação, novamente destacando a importância do substrato na análise imunológica. Com relação aos tipos e tempo de interação com linfócitos $\mathrm{T} \mathrm{CD}^{+} \mathrm{CD}^{+}$, observamos uma diminuição inversamente proporcional ao estágio de maturação das DCs, sendo que no grupo 48h-mDCs, obtivemos uma média do tempo de interação 2 vezes menor do que no grupo 0h-DCs e estas interações foram em sua maioria com um único linfócito. Já a interação com linfócitos $\mathrm{T} C D 3^{+} \mathrm{CD} 8^{+}$, mostra um padrão diferente, sendo que não ocorre diferença entre o tempo de interação nos diferentes estágios de maturação das DCs no grupo Col III, mas o tipo de interação muda completamente no grupo $48 \mathrm{~h}-\mathrm{mDCs}$, onde em todas as análises, a mesma DC interagiu repetidas vezes com o mesmo linfócito.

Esses resultados de tipo e tempo de interações são muito discutidos na literatura, sendo que estudos utilizando imagens intravitais revelaram um modelo de 3 fases de interações entre linfócitos $\mathrm{T} \mathrm{CD}^{+}$antígeno-específicos e DCs em linfonodos de camundongos (MEMPEL; HERNRICKSON; VON ANDRIAN, 2004). Neste modelo, identificaram-se interações de curta duração (raramente superior a 30 minutos) de um linfócito com um grande número de DCs, nas primeiras 8 horas após a transferência dos linfócitos para o animal (previamente inoculado com DCs pulsadas com o antígeno). Estas foram seguidas, a partir das 12 horas pós-transferência, por interações estáveis (a maioria com mais do que 60 minutos de interação, sendo que algumas ainda se mantiveram estáveis após 20-26 horas) dos linfócitos com DCs individuais e, depois de um dia, as células voltaram a apresentar perfis de interação semelhantes aos da primeira fase (MEMPEL; HERNRICKSON; VON ANDRIAN, 2004). Em outros estudos realizados in vitro em matriz 3D composta por colágeno tipo I, DCs e linfócitos $\mathrm{T}$ apresentaram interações célula-célula individuais transientes (em média 3-20 min), que levaram à ativação dos linfócitos T. Neste sistema, observou-se que após a separação de uma determinada DC, os linfócitos T continuaram a migrar dentro de colágeno e estabeleceram interações consecutivas com a mesma DC ou com uma DC vizinha (FRIEDL; GUNZER, 2001; GUNZER et al., 2000b). Por outro lado, há trabalhos que descrevem que uma sinapse madura entre os linfócitos T e as DCs requer pelo menos 30 minutos (LEE et al., 2002) e que interações de curta duração (com menos de 30 minutos), não são indutoras de maturação (LEE et al., 2002; MEMPEL; HERNRICKSON; VON ANDRIAN, 2004). 
Devido aos dados aparentemente contraditórios sobre a interação de linfócitos e DCs, duas teorias foram desenvolvidas: a do encontro único e a do encontro seriado (FRIEDL; GUNZER, 2001; IEZZI; KARJALAINEN; LANZAVECCHIA, 1998; ZARNITSYNA; ZHU, 2012). A teoria do encontro seriado propõe que um linfócito $T$ acumule vários sinais de curta duração de vários encontros com as mesmas ou diferentes DCs, prevendo que os linfócitos T devem ser capazes de memorizar a qualidade e a quantidade de seus encontros com DCs até que se atinja o limiar de ativação. A teoria do encontro único, por outro lado, afirma que os linfócitos $\mathrm{T}$ devem estabelecer uma única e longa interação com uma DC para sua correta ativação. É importante ressaltar que o nosso método de análise, foi baseado em imagem adquiridas em intervalos de 20 minutos ao longo de 17 horas, considerando somente o modelo do encontro único, já que em nossas condições, interações de curta duração entre DCs e linfócitos T diferentes, não teriam sido detectadas. Portanto, não temos como saber em nosso modelo se estão ocorrendo interações curtas, condizentes com o modelo de encontro seriado proposto (FRIEDL; GUNZER, 2001; IEZZI; KARJALAINEN; LANZAVECCHIA, 1998; ZARNITSYNA; ZHU, 2012). Já com relação ao modelo de encontro único, nossos dados comprovam outros estudos, pois é conhecido que DCs maduras possuem maior capacidade de ativação linfocitária (BANCHEREAU et al., 2000; NUSSENZWEIG; STEINMAN, 1980; STEINMAN; WITMER, 1978) e que uma interação única e longa é considerada como a mais eficaz para ativação total dos receptores de células $\mathrm{T}$ (TCR) dos linfócitos (IEZZI; KARJALAINEN; LANZAVECCHIA, 1998; MEMPEL; HERNRICKSON; VON ANDRIAN, 2004). Interessantemente, no nosso modelo, os dados sugerem que possa ainda existir uma terceira forma de interação: a do encontro seriado longo. Em nossos experimentos, além de DCs que interagiram com apenas um linfócito T de forma longa - e concordando com a teoria do encontro único -, encontramos outras DCs que interagiram com mais de um linfócito $\mathrm{T}$, porém de maneira longa. Descritos pelo nosso grupo pela primeira vez (STEPONAVICIUS-CRUZ; FREITAS; BARBUTO, 2013), esses dados mostram que uma DC é capaz de interagir com vários linfócitos por períodos similares aos caracterizados no encontro único, sendo então denominado de encontro seriado longo. Ao menos, considerando a ativação dos linfócitos, a modulação funcional das DCs, pelo encontro com linfócitos T poderia ser modificada pelos encontros seriados longos com os linfócitos. Por outro lado, é necessário notar que a extrapolação destes resultados para os fenômenos in vivo teria que considerar ainda que no tecido linfático as densidades celulares são muito elevadas (GRETZ; ANDERSON; SHAW, 1997; USHIKI; OHTANI; ABE, 1995) e interações célula-célula são observadas em maior número e frequência (INGULLI et al., 1997). 
Em adição, foi analisada a migração de células que não apresentaram interações no ambiente 3D com e sem colágeno III. Nossos resultados não mostraram diferenças significantes na migração de DCs ou de linfócitos $\mathrm{T} \mathrm{CD} 3^{+} \mathrm{CD} 4^{+}$, mas a presença ou não de colágeno III foi mais importante para a migração de linfócitos $\mathrm{T} \mathrm{CD}^{+} \mathrm{CD}^{+}$, que apresentaram uma tendência a mudar sua velocidade de migração de acordo com qual DC foram cocultivados e com a presença de substrato. Esses resultados mostram que é possível que ocorra algum tipo de sinalização de DCs a longa distância para induzir mudança de velocidade dos linfócitos $\mathrm{T} \mathrm{CD}^{+} \mathrm{CD}^{+}$e que essa sinalização parece sofrer influência da presença de colágeno III. Ainda, no grupo 48h-mDCs, houve uma tendência do colágeno III em diminuir a velocidade de DCs e linfócitos $\mathrm{T} \mathrm{CD}^{+} \mathrm{CD}^{+}$. Em conjunto, esses resultados indicam que a presença de um substrato ou mesmo a presença de outro tipo celular cocultivado podem alterar a migração das células imunológicas e que a decisão de como o experimento será realizado pode influenciar o resultado final, principalmente se as condições dos experimentos não levarem em consideração a riqueza do microambiente onde ocorrem as interações celulares e o tipo celular envolvido no processo. Fato corroborado na literatura, sendo que Gunzer et al. (2000b) mostraram que uma matriz 3D de colágeno I facilita não somente a migração de linfócitos em direção a uma APC, mas também é capaz de dar suporte à interação célula-célula. Já outro grupo mostrou que linfócitos $\mathrm{T}$ humanos são capazes de migrar em ambiente 3D revestido de colágeno do tipo I, mas não em Matrigel (COUGOULE et al., 2012), enquanto um terceiro estudo mostrou que linfócitos T humanos, quando ativados por anticorpos anti-CD3, possuem uma capacidade migratória 3 vezes maior em uma matriz 3D revestida de Matrigel (HACHEHOUCHE; CHETOUI; AOUDJIT 2010). Outros estudos mostraram que os linfócitos $\mathrm{T}$ migraram mais rapidamente do que os linfócitos $\mathrm{B}$ ou DCs (BOUSSO; ROBEY, 2003; MILLER et al., 2002). Além disso, os valores medidos no tecido linfático intacto assemelhavam-se aqueles para os mesmos tipos de células obtidos em matrizes tridimensionais de colágenos (DORNER et al., 1997; ENTSCHLADEN et al., 1997; FRIEDL; NOBLE; ZÄNKER, 1993, FRIEDL ET AL., 1994, 1998; GUNZER et al., 2000a).

Em outro tipo de análise, as células que interagiram foram mensuradas quanto a sua velocidade antes e após a interação. Interessantemente, 48h-mDCs com colágeno III que não interagiram tiveram uma velocidade média de $10 \mu \mathrm{m} / \mathrm{min}$, enquanto DCs que interagiram com algum linfócito apresentaram velocidade média de $2 \mu \mathrm{m} / \mathrm{min}$ antes da interação e de 6 $\mu \mathrm{m} / \mathrm{min}$ após a interação com um linfócito $\mathrm{T} \mathrm{CD}^{+} \mathrm{CD}^{+}$ou permaneceram com $2 \mu \mathrm{m} / \mathrm{min}$ após interação com um linfócito $\mathrm{T} C D 3^{+} \mathrm{CD} 8^{+}$, o que mostra ser possível indicar se uma DC vai interagir com um linfócito apenas pela sua velocidade de migração média, também 
indicando que quimiocinas podem estar envolvidas na atração de DCs até os linfócitos e que o gradiente de concentração delas pode reduzir a velocidade das DCs para que a interação ocorra. No entanto, porque DCs que interagiram com um linfócito $\mathrm{T} \mathrm{CD} 3{ }^{+} \mathrm{CD} 4^{+}$aumentam sua velocidade, enquanto as que interagiram com um linfócito $\mathrm{T} \mathrm{CD} 3^{+} \mathrm{CD} 8^{+}$não mudaram sua velocidade, é um mistério. Quando analisados os linfócitos que interagiram no grupo 48hmDCs com colágeno III, o padrão de diminuição de velocidade encontrado nas DCs também foi encontrado nos linfócitos, que, após a interação, apresentaram velocidade média de $1 \mathrm{um} / \mathrm{min}$. Assim como os resultados anteriores, estes novos dados podem ser explicados por diferentes citocinas e quimiocinas produzidas por essas células. Alguns dos possíveis candidatos seriam a CCL19, quimiocina produzida por DCs maduras dentro de linfonodos e que atrai linfócitos naive para as DCs (BREART; BOUSSO, 2006; DIEU et al., 2003); ou CCL17 e CCL22, que são produzidas pelas DCs e também ajudam a garantir que linfócitos T movam-se em direção a elas (ALFERINK et al., 2003; VULCANO et al., 2001). Outra hipótese poderia ser a presença das quimiocinas CCL3 e CCL4. Castellino et al. (2006) mostraram que linfócitos $\mathrm{T} \mathrm{CD}^{+} \mathrm{CD}^{+}$(após imunização, mas antes do reconhecimento do antígeno em linfonodos) regulam o CCR5, permitindo que estas células sejam atraídas para os locais de interação com as DCs. Ainda, nossos resultados mostram que existe um efeito na diminuição da velocidade dessas células após o contato, sendo que esta mudança parece estar relacionada com o estágio de maturação das DCs, confirmando dados da literatura (BENVENUTI et al., 2004; GUNZER et al., 2000b).

Com relação aos ensaios funcionais, excluindo o aumento de IL-6 e TNF do grupo 2hmDCs, o qual pode ser explicado pelo pouco tempo após a adição do estímulo de maturação com o próprio TNF- $\alpha$, parece haver uma produção basal dos mesmos em todos os grupos estudados, independentemente do substrato utilizado. Por outro lado, é nítida a importância do colágeno tipo III para a função das células no grupo $48 \mathrm{~h}-\mathrm{mDCs}$, induzindo um aumento significante de IL-2 quando em presença do substrato e levando a uma supressão de sua produção na ausência do mesmo. Esta produção de IL-2 poderia induzir a um aumento na proliferação dos linfócitos, mas o mesmo não foi observado em nossos experimentos, embora pareça existir uma tendência a aumentar no grupo 48h-mDCs com colágeno III quando comparado ao sem colágeno. Além disso, nos grupos $0 \mathrm{~h}-\mathrm{DCs}$ e $2 \mathrm{~h}-\mathrm{mDCs}$, as células proliferaram um pouco mais sem o substrato, fato que se inverte no grupo 48h-mDCs. Embora esperada uma maior proliferação dos linfócitos pelo aumento de IL-2, é necessário ressaltar que, com mais variáveis do que uma cocultura 2D, os efeitos da IL-2 podem ser diferentes aos esperados, sabendo que esta citocina desempenha muitos papéis diferentes, 
como aumento de sobrevivência celular (VAN PARIJS et al., 1999), apoptose Fas dependente de linfócitos reativos (LENARDO et al., 1999), indução de fenótipo regulatório através da expressão de FoxP3 (SHEVACH, 2009), além de participar também da diferenciação dos linfócitos em perfil Th1 (LIAO; LIN; LEONARD, 2011) e Th2 (LIAO et al., 2008) e inibir a diferenciação de linfócitos Th17 (LAURENCE et al., 2007) e linfócitos $\mathrm{T}$ auxiliares foliculares (BALLESTEROS-TATO et al., 2012).

Um importante fato a ser considerado é a importância do grupo 48h-mDCs. Este é o grupo utilizado para a aplicação da vacina terapêutica (BARBUTO et al., 2004; NEVES et al., 2005; PINHO et al., Submetido). Nenhuma citocina com caráter tolerogênico foi encontrada neste grupo quando as células foram cultivadas sem substrato, indicando ainda uma diminuição da IL-2 basal. Já quando o colágeno III foi utilizado, ocorreu um aumento importante da produção de IL-2, induzida pela interação somente das células dendríticas totalmente maduras com o colágeno III. Interessantemente, já foi relatado que o colágeno III se liga e aprisiona IL-2, sendo capaz de regular sua biodisponibilidade (SOMASUNDARAM et al., 2000) e também modular sua função, já que pode sinalizar via integrinas dos linfócitos T para induzir aumento da expressão de p55 e p75 (TSCHOETSCHEL et al., 1997), importantes proteínas que compõe o receptor de IL-2, além de aumentar a atividade coestimuladora em linfócitos T (RAO; HALES; CAMP, 2000). Em conjunto, podemos concluir que nosso experimento mimetizou o fato de apenas DCs maduras agirem diferentemente na presença do colágeno III, visto que essas células são as que entram em contato com este componente da matriz ao chegarem na região paracortical dos linfonodos. E ainda, que embora o estímulo de maturação seja suficiente para analisarmos o fenótipo e a mudança funcional das DCs em culturas convencionais, a adição de variáveis como o colágeno III e outras moléculas que possam mimetizar o microambiente da região paracortical do linfonodo, podem ajudar em um maior entendimento da real fisiologia dessas células.

Em seguida, analisamos todos os parâmetros anteriores em células dendríticas fundidas com células tumorais de pacientes com câncer de mama ou com células da linhagem SKBR-3 cocultivadas com linfócitos $\mathrm{T}$. Como o colágeno III apresentou resultados promissores, utilizamos este substrato e montamos o ambiente 3D para as células, o qual acreditamos que poderia contribuir para o aperfeiçoamento da estratégia imunoterapêutica utilizada em nosso laboratório.

Nosso modelo 3D permitiu interações entre células híbridas do grupo Fusão Tumoral com linfócitos $\mathrm{T} \mathrm{CD} 3^{+} \mathrm{CD} 4^{+}$e linfócitos $\mathrm{T} \mathrm{CD} 3^{+} \mathrm{CD}^{+}$, enquanto células híbridas do grupo Fusão Linhagem apenas interagiram com linfócitos $\mathrm{T} C D 3^{+} \mathrm{CD} 4^{+}$, o que pode significar um 
comportamento diferente desta linhagem em relação ao comportamento das células derivadas de tumores. Um fato que pode suportar essa idéia é de que a SKBR-3 não possui a expressão de moléculas do MHC classe I e expressa em grandes quantidades o Her2/neu (PINHO, 2014), sendo que é conhecido que a perda da expressão de moléculas de classe I do MHC ou dos componentes da maquinaria de processamento de antígenos representa um importante mecanismo de escape tumoral, impedindo seu reconhecimento por linfócitos $\mathrm{T} \mathrm{CD} 3^{+} \mathrm{CD} 8^{+}$ (SELIGER, 2008), sendo justamente as células que não interagiram com o grupo Fusão Linhagem. Ainda, Kaneko et al. (2011) mostraram que a ausência de moléculas de classe I do MHC em células de câncer de mama está associada com um pior prognóstico desses tumores. Com consequências semelhantes, a expressão aumentada de Her2/neu é capaz de diminuir a expressão de diversas proteínas responsáveis pelo processamento de antígenos (HERRMANN et al., 2004). Assim, a SKBR-3 (mesmo fundida com 48h-mDCs) pode ser considerada como “invisível” aos linfócitos $\mathrm{T} C D 8^{+}$, sendo então resistente à morte induzida por estas células. Esse mecanismo parece não se aplicar às células tumorais, ou ainda é possível que a fusão com 48h-mDCs torne possível a interação com linfócitos $\mathrm{T} C D 3^{+} \mathrm{CD} 8^{+}$. De qualquer maneira, enquanto $48 \mathrm{~h}-\mathrm{mDCs}$ sem fusão interagem em proporção maior com linfócitos $\mathrm{T} \mathrm{CD} 3{ }^{+} \mathrm{CD} 4^{+}$ do que com linfócitos $\mathrm{T} \mathrm{CD}^{+} \mathrm{CD}^{+}$, após a fusão com as células tumorais, parece não haver um tipo celular de preferência, sendo que a células do grupo Fusão Tumoral interagiram de maneira semelhante com os dois tipos de linfócitos $\mathrm{T}$ analisados.

Com relação ao tempo e tipos de interação com linfócitos $\mathrm{T} \mathrm{CD} 3^{+} \mathrm{CD} 4^{+}$, obtivemos uma média do tempo de interação 2 vezes maior no grupo Fusão Linhagem do que nos outros grupos e essas interações possuíram um perfil parecido com o do grupo Sem Fusão, parecendo haver uma preferência a interações de encontro único com linfócitos $\mathrm{T} \mathrm{CD}^{+} \mathrm{CD} 4^{+}$. Interessantemente, no grupo Fusão Tumoral, todas as interações foram de encontro serial longo, caracterizando muitas interações com diferentes linfócitos. Já a interação com linfócitos $\mathrm{T} \mathrm{CD}^{+} \mathrm{CD}^{+}$, mostra um padrão diferente, sendo que ocorre um aumento do tempo de interação do grupo Fusão Tumoral comparado aos outros grupos. Ainda neste grupo, existe uma mudança dos tipos de interação quando comparado ao grupo Sem Fusão, sendo que 50\% dos tipos de interação passam a ser de encontro serial longo. Esses resultados mostram que no grupo Fusão Tumoral existe uma predisposição a interações de encontro serial longo, descritas pela primeira vez por nosso grupo (STEPONAVICIUS-CRUZ; FREITAS; BARBUTO, 2013). Em conjunto, isso pode indicar que em nosso caso, a vacina parece estar ativando os linfócitos $\mathrm{T}$ de uma maneira melhor, visto que esse tempo das interações seria o mais eficaz para ativação total do TCR dos linfócitos (IEZZI; KARJALAINEN; 
LANZAVECCHIA, 1998; MEMPEL; HERNRICKSON; VON ANDRIAN, 2004).

Quando a migração das DCs e células híbridas que não interagiram foi analisada, nossos resultados mostraram que a média da migração das células híbridas foi bem reduzida em relação ao grupo Sem Fusão. Essa redução da velocidade de migração pode ser explicada talvez pelo maior volume das células híbridas (SERHAL et al., 2007), além também de uma desorganização da membrana citoplasmática e do citoesqueleto pelo próprio processo de eletroporação (HARKIN; HAY, 1996; KANTHOU et al., 2006). É interessante notar que a interação das células híbridas e das DCs com linfócitos $\mathrm{T} \mathrm{CD} 3^{+} \mathrm{CD}^{+}$acelera a velocidade de migração das mesmas. Vale ainda ressaltar que o mesmo não é observado após a interação destas com linfócitos $\mathrm{T} \mathrm{CD}^{+} \mathrm{CD}^{+}$. Este fenômeno é intrigante e até onde se pôde investigar, não relatado na literatura. Embora especulativamente pode-se sugerir que a interação com linfócitos $\mathrm{T} \mathrm{CD}^{+} \mathrm{CD}^{+}$aumenta a atividade das DCs, tornando-as mais móveis e, portanto, aumentando sua possibilidade de interação com os outros linfócitos T, favorecendo assim, ainda mais o desencadeamento da resposta imune.

Com relação à migração dos linfócitos, os linfócitos $\mathrm{T} C D 3^{+} \mathrm{CD} 8^{+}$que não interagiram apresentaram velocidade parecida em todos os grupos, mas a migração de linfócitos $\mathrm{T}$ $\mathrm{CD}^{+} \mathrm{CD}^{+}$que não interagiram foi maior no grupo Fusão Linhagem e bem reduzida no grupo Fusão Tumoral, talvez indicando algum tipo de regulação à distância, onde os linfócitos $\mathrm{T}$ $\mathrm{CD}^{+} \mathrm{CD}^{+}$cocultivados com células do grupo Fusão Tumoral seriam mais lentos provavelmente devido a diferenças de produção de algum quimioatraente. Ainda, quando analisada a velocidade desses linfócitos antes e depois de interagirem, não houveram grandes diferenças, mostrando inclusive que as DCs e as células híbridas apresentam uma velocidade maior do que os linfócitos após a interação com essas células, quando o esperado talvez seria o oposto, já que são os linfócitos que são ativados e deixariam o linfonodo para se dirigirem ao local do perigo.

Até então, a vacina terapêutica usando células de câncer de mama apresentou resultados interessantes nos nossos experimentos, como taxas e tempo de interações celulares parecidas com de DCs maduras, tipo de interações celulares aparentemente melhorado para uma ativação mais eficaz de um número maior de linfócitos e velocidade de migração compatível. No entanto, quando analisamos os resultados funcionais, a expressão de IL-2 existente no grupo de células Sem Fusão desaparece totalmente nos grupos de células híbridas, assim como a proliferação de linfócitos, que foi praticamente nula no grupo Fusão Tumoral. Logo, a vacina de células híbridas de câncer de mama parece interagir melhor com os linfócitos, mas acaba inibindo a atividade dessas células. Essa inibição pode ser explicada 
possivelmente pela baixa expressão de antígeno leucocitário humano-I (HLA-I) convencionais e alta expressão de HLA-G pelas células do carcinoma ductal invasivo (JEONG et al., 2014; LOUMAGNE et al., 2014; RAMOS et al., 2014). O HLA-G faz parte dos HLA-I não convencionais e é expresso principalmente por células trofoblásticas invasivas da placenta (LE BOUTEILLER et al., 1999) e de diversos tipos de tumores invasivos (ALGARRA et al., 2004; DAVIDSON et al., 2005; DUTTA et al., 2005; IBRAHIM et al., 2001, 2004), sendo responsável por um dos mecanismos de evasão imunológica mais conhecidos, capaz de induzir imunotolerância local via interação célula-célula e sistêmica através da produção de isoformas de HLA-G solúveis (FAVIER et al., 2007; LE BOUTEILLER et al., 1999). Além disso, o HLA-G expresso por uma célula tumoral é capaz de induzir inibição de maturação de DCs e da apresentação de antígeno, gerar linfócitos T reguladores e inibir proliferação de linfócitos, assim como citotoxicidade celular e gerar anergia (RAMOS et al., 2014; SHIROISHI et al., 2003). Logo, é possível que esta molécula esteja por trás dos efeitos inibitórios encontrados nos linfócitos após interação com as células híbridas, possivelmente entrando em anergia, entretanto, mais estudos necessitam ser realizados para comprovar esta teoria.

Em suma, nosso trabalho demonstrou a grande variedade de resultados passíveis de análise quanto às interações celulares em ambientes tridimensionais e como a escolha do microambiente de cocultura 3D pode afetar tais resultados. Em nossos resultados, a matriz 3D Biotek e o colágeno III aumentaram significativamente a porcentagem, o tipo e o tempo de interaçoões, assim como a migração de DCs e linfócitos e a produção de citocinas. Em nossas condições, as DCs interagiram de maneira mais homogênea com linfócitos $\mathrm{T} C D 3^{+} \mathrm{CD} 8^{+}$, enquanto as interações com linfócitos $\mathrm{T} \mathrm{CD} 3^{+} \mathrm{CD}^{+}$foram alteradas pela maturação das DCs e a presença de diferentes substratos. Com relação às células fusionadas, fica claro como a Fusão Linhagem possui características diferentes da Fusão Tumoral e deve-se manter cautela com o uso de linhagens como a SKBR-3 para mimetizar o comportamento de células obtidas diretamente das pacientes com câncer de mama. De modo geral, a fusão com células tumorais ex vivo foi capaz de aumentar tanto a porcentagem, quanto o tempo e o tipo de interações. No entanto, a regulação negativa de IL-2 e a ausência de proliferação linfocitária após estas interações parecem sugerir que as células híbridas seriam pobres ativadoras da resposta imune. No entanto, várias explicações alternativas podem ser sugeridas para esta observação: o tratamento das DCs para a fusão poderia provocar, de fato, uma mudança na atividade dessas células, o que seria, de certa forma, difícil de conciliar com os resultados positivos observados clinicamente; o fenômeno seria restrito a tumores de mama, indicando que 
moléculas presentes em células dos tumores de mama e, portanto, carregadas para as células híbridas, seriam as responsáveis por essa regulação funcional negativa dos linfócitos; ou, ainda, a produção de IL-2 e a proliferação linfocitária in vitro não seriam bons indicadores de uma resposta clínica. Fica claro, portanto, que seja qual for a explicação para o fenômeno observado, ainda são necessários mais estudos para entender o funcionamento das células híbridas dendríticas-tumorais e como podemos melhorá-las para aplicação em vacinas terapêuticas. 


\section{CONCLUSÃO}

Neste trabalho apresentamos um novo modelo de cocultura 3D in vitro que permitiu determinar as consequências da interação de diferentes células apresentadoras de antígenos com linfócitos $\mathrm{T}$, indicando haver grande influência dos componentes usados na construção do ambiente, das células e do estado de maturação das mesmas sobre o efeito que exercem sobre os linfócitos $\mathrm{T}$, os quais apresentam modificações em sua atividade migratória, sua proliferação e produção de citocinas, todas mensuráveis no modelo.

Assim, pode-se concluir que esta forma de análise pode contribuir de maneira significativa para a compreensão da biologia da resposta imunológica de modo geral e, especificamente, para o aprimoramento de estratégias de imunização utilizando células apresentadoras de antígenos geradas in vitro, como é o caso da imunização com células híbridas dentríticas-tumorais para o tratamento do câncer.

Usando este método, foi possível concluir que:

$\checkmark$ O ambiente 3D Biotek acrescido de colágeno III permite análise tridimensional das interações celulares de maneira reprodutiva;

$\checkmark$ Embora outras interações entre DCs e linfócitos T prescindam do colágeno III, a presença deste é necessária para que se observem interações entre linfócitos $\mathrm{T}$ $\mathrm{CD} 3^{+} \mathrm{CD} 4^{+}$e DCs;

$\checkmark$ Os parâmetros analisados (porcentagem, tipo e tempo) das interações celulares de DCs em diferentes estágios de maturação com diferentes subpopulações de linfócitos $\mathrm{T}$ permitiram a sugestão de um novo modelo de interação entre estas células: o modelo de encontro seriado longo;

$\checkmark$ A presença de um substrato e a presença de DCs em diferentes estágios de maturação podem alterar a migração dos linfócitos $\mathrm{T} \mathrm{CD} 3^{+} \mathrm{CD} 8^{+}$;

$\checkmark$ A fase de maturação das DCs afeta suas interações com os linfócitos T e também o comportamento dos linfócitos $\mathrm{T}$, tanto dos que que interagiram diretamente com elas quanto dos que não o fazem diretamente;

$\checkmark$ A maturação completa das DCs e a presença de colágeno III induziram a produção de IL-2 nas co-culturas com linfócitos T, indicado que possa estar ocorrendo uma ativação fisiológica do sistema imunológico que, consequentemente, é acompanhada da expressão de moléculas reguladoras dessa mesma ativação. 
$\checkmark$ Os resultados dos grupos Fusão Linhagem e Fusão Tumoral indicam que o uso da linhagem SKBR-3 não é aconselhado para estes ensaios de interação celular e protocolo de vacinação, pois células híbridas que as contêm, possuem comportamento diverso daquelas produzidas a partir de células obtidas diretamente dos tumores das pacientes;

$\checkmark$ Quando analisados porcentagem, tempo e tipo de interações, o grupo Fusão Tumoral mostrou interações com linfócitos $\mathrm{T} \mathrm{CD}^{+} \mathrm{CD}^{+}$e com linfócitos $\mathrm{T}$ $\mathrm{CD}^{+} \mathrm{CD}^{+}$observando uma predisposição a interações de encontro serial longo, embora não estão sendo ativados após a interação;

$\checkmark$ Células híbridas apresentaram a velocidade de migração reduzida quando comparadas as DCs. 


\section{REFERÊNCIAS ${ }^{1}$}

ADAMS, J. C.; WATT, F. M. Regulation of development and differentiation by the extracellular matrix. Development., v. 117, n. 4, p. 1183-1198, 1993

ALFERINK, J.; LIEBERAM, I.; REINDL. W.; BEHRENS, A.: WEISS, S.; HÜSER, N.; GERAUER, K.; ROSS, R.; RESKE-KUNZ, A. B.; AHMAD-NEJAD, P.; WAGNER, H. FÖRSTER, I. Compartmentalized production of CCL17 in vivo: strong inducibility in peripheral dendritic cells contrasts selective absence from the spleen. J. Exp. Med., v. 197, n. 5, p. 585-599, 2003.

ALGARRA, I.; GARCÍA-LORA, A.; CABRERA, T.; RUIZ-CABELLO, F., GARRIDO, F. The selection of tumor variants with altered expression of classical and nonclassical MHC class I molecules: implications for tumor immune escape. Cancer Immunol. Immunother., v. 53, n. 10, p. 904-910, 2004

AQUINO, A.; GRAZIANI, G.; FRANZESE, O.; PRETE, S. P.; BONMASSAR, E.; BONMASSAR, L.; D'ATRI, S. Exogenous control of the expression of Group I CD1 molecules competent for presentation of microbial nonpeptide antigens to human $T$ lymphocytes. Clin. Dev. Immunol., v. 2011, p. 1-27, 2011.

ARDAVÍN, C.; MARTÍNEZ DEL HOYO, G.; MARTÍN, P.; ANJUÈRE, F.; ARIAS, C. F.; MARÍN, A. R.; RUIZ, S.; PARRILLAS, V.; HERNÁNDEZ, H. Origin and differentiation of dendritic cells. Trends Immunol., v. 22, n. 12, p. 691-700, 2001.

AZEVEDO, A. P. S.; LAGINHA, F.; BARBUTO, J. A. M. Phenotypic and functional characterization of monocyte-derived dendritic cells from breast cancer patients. In: 13TH INTERNATIONAL CONGRESS OF IMMUNOLOGY, 2007. Abstracts. Rio de Janeiro, 2007, res. G07-099.

BAKER, B. M.; CHEN, C. S. Deconstructing the third dimension: how 3D culture microenvironments alter cellular cues. J. Cell. Sci., v. 1, n. 125, p. 3015-3024, 2012.

BALEEIRO, R.; DAHNE, L.; BAUDE, B.; LADEMANN, J.; WIESMULLER, K.; WALDEN, P. Induction of specific CD8+ T cell proliferation by human DC loaded with peptide coupled to TLR agonist. In: INTERNATIONAL SYMPOSIUM ON DENDRITIC CELLS IN FUNDAMENTAL AND CLINICAL IMMUNOLOGY, 2010. Abstracts. Lugano, Suiça: Institute for Research in Biomedicine and Swiss Vaccine Research Institute, 2010. res. P03- 081.

BALlESTEROS-TATO, A.; LEÓN, B.; GRAF, B. A.; MOQUIN, A.; ADAMS, P. S.; LUND, F. E.; RANDALL, T. D. Interleukin-2 inhibits germinal center formation by limiting $\mathrm{T}$ follicular helper cell differentiation. Immunity., v. 36, n. 5. p. 586-847, 2012.

BANCHEREAU, J.; BRIERE, F.; CAUX, C.; DAVOUST, J.; LEBECQUE, S.; LIU, Y. J. PULENDRAN B, PALUCKA K. Immunobiology of dendritic cells. Annu. Rev. Immunol., v. 18, n. 3, p. 767-811, 2000.

${ }^{1}$ De acordo com: ASSOCIAÇÃO BRASILEIRA DE NORMAS TÉCNICAS. NBR 6023:

Informação e documentação: referências: elaboração. Rio de Janeiro, 2002. 
BANCHEREAU, J.; STEINMAN, R. M. Dendritic cells and the control of immunity. Nature, v. 392, n. 6673, p. 245-52, 1998.

BARBUTO, J. A. Are dysfunctional monocyte-derived dendritic cells in cancer an explanation for cancer vaccine failures? Immunotherapy., v. 5, n. 2, p. 105-107, 2013.

BARBUTO, J. A.; ENSINA, L. F.; NEVES, A. R.; BERGAMI-SANTOS, P.; LEITE, K. R.; MARQUES, R.; COSTA, F.; MARTINS, S. C.; CAMARA-LOPES, L. H.; BUZAID, A. C. Dendritic cell-tumor cell hybrid vaccination for metastatic cancer. Cancer Immunol. Immunother., v. 53, n. 12, p. 1111-1118, 2004.

BENVENUTI, F.; LAGAUDRIÈRE-GESBERT, C.; GRANDJEAN, I.; JANCIC, C.; HIVROZ, C.; TRAUTMANN, A.; LANTZ, O.; AMIGORENA, S. Dendritic cell maturation controls adhesion, synapse formation, and the duration of the interactions with naive $\mathrm{T}$ lymphocytes. J. Immunol., v. 172, n. 1, p. 292-301, 2004.

BONIFAZ, L.C.; BONNYAY, D.P.; CHARALAMBOUS, A.; DARGUSTE, D. I.; FUJII, S.; SOARES, H.; BRIMNES, M. K.; MOLTEDO, B.; MORAN, T. M.; STEINMAN, R. M. In vivo targeting of antigens to maturing dendritic cells via the DEC-205 receptor improves $T$ cell vaccination. J. Exp. Med., v. 199, n. 6, p. 815-824, 2004.

BOUSSO, P.; ROBEY, E. Dynamics of CD8+ T cell priming by dendritic cells in intact lymph nodes. Nat. Immunol., v. 4, n. 6, p. 579-585, 2003.

BREART, B.; BOUSSO, P. Cellular orchestration of $\mathrm{T}$ cell priming in lymph nodes. Curr. Opin. Immunol., v. 18, n. 4, p. 483-490, 2006.

CAO, X.; SUGITA, M.; VAN DER WEL, N.; LAI, J.; ROGERS, R. A.; PETERS, P. J.; BRENNER, M. B. CD1 molecules efficiently present antigen in immature dendritic cells and traffic independently of MHC class II during dendritic cell maturation. J. Immunol., v. 169, n. 9 , p. 4770-4777, 2002.

CARBONE FR1, KURTS C, BENNETT SR, MILLER JF, HEATH WR. Cross-presentation: a general mechanism for CTL immunity and tolerance. Immunol. Today., v. 19, n. 8, p. 368373, 1998.

CARREL, A. On the permanent life of tissues outside of the organism. J. Exp. Med., v. 15, n. 5, p. 516-528, 1912.

CASEY, D. G.; LYSAGHT, J.; JAMES, T.; BATEMAN, A.; MELCHER, A. A.; TODRYK, S. M. Heat shock protein derived from a non-autologous tumour can be used as an antitumour vaccine. Immunology., v. 110, n. 1, p. 105-111, 2013.

CASTAÑOS-VELEZ, E.; BIBERFELD, P.; PATARROYO, M. Extracellular matrix proteins and integrin receptors in reactive and non-reactive lymph nodes. Immunology., v. 86, n. 2, p. 270-278, 1995.

CASTELLINO, F.; HUANG, A. Y.; ALTAN-BONNET, G.; STOLL, S.; SCHEINECKER, C.; GERMAIN, R. N. Chemokines enhance immunity by guiding naive CD8+ T cells to sites of CD4+ T cell-dendritic cell interaction. Nature., v. 440, n. 7086, p. 890-895, 2006. 
CAUX, C.; MASSACRIER, C.; VANBERVLIET, B.; DUBOIS, B.; VAN KOOTEN, C.; DURAND, I.; BANCHEREAU, J. Activation of human dendritic cells through CD40 crosslinking. J. Exp. Med., v. 180, n. 4, p. 1263-1272, 1994.

Caux, C.; Vanbervliet, B.; Massacrier, C.; Dezutter-Dambuyant, C.; de Saint-Vis, B.; Jacquet, C.; Yoneda, K.; Imamura, S.; Schmitt, D.; Banchereau, J. CD34+ hematopoietic progenitors from human cord blood differentiate along two independent dendritic cell pathways in response to GM-CSF+TNF alpha. J. Exp. Med., v. 184, n. 2, p. 695-706, 1996.

CHAPUT, N.; SCHARTZ, N. E.; ANDRÉ, F.; TAÏEB, J.; NOVAULT, S.; BONNAVENTURE, P.; AUBERT, N.; BERNARD, J.; LEMONNIER, F.; MERAD, M.; ADEMA, G.; ADAMS, M.; FERRANTINI, M.; CARPENTIER, A. F.; ESCUDIER, B.; TURSZ, T.; ANGEVIN, E.; ZITVOGEL, L. Exosomes as potent cell-free peptide-based vaccine. II. Exosomes in $\mathrm{CpG}$ adjuvants efficiently prime naive Tc1 lymphocytes leading to tumor rejection. J. Immunol., v. 172, n. 4, p. 2137-2146, 2004.

CHIANG, C. L.; KANDALAFT, L. E.; TANYI, J.; HAGEMANN, A. R.; MOTZ, G. T.; SVORONOS, N.; MONTONE, K.; MANTIA-SMALDONE, G. M.; SMITH, L.; NISENBAUM, H. L.; LEVINE, B. L.; KALOS, M.; CZERNIECKI, B. J.; TORIGIAN, D. A.; POWELL, D. J. JR.; MICK, R.; COUKOS, G. A dendritic cell vaccine pulsed with autologous hypochlorous acid-oxidized ovarian cancer lysate primes effective broad antitumor immunity: from bench to bedside. Clin. Cancer Res., v. 19, n. 17, p. 4801-4815, 2013.

COLLIN, M.; MCGOVERN, N.; HANIFFA, M. Human dendritic cell subsets. Immunology., v. 140, n. 1, p. 22-30, 2013.

COLONNA, M.; TRINCHIERI, G.; LIU, Y. J. Plasmacytoid dendritic cells in immunity. Nat. Immunol., v. 5, n. 12, p. 1219-1226, 2004.

CÔTÉ, S. C.; PASVANIS, S.; BOUNOU, S.; DUMAIS, N. CCR7-specific migration to CCL19 and CCL21 is induced by PGE(2) stimulation in human monocytes: Involvement of EP(2)/EP(4) receptors activation. Mol. Immunol., v. 46, n. 13, p. 2682-2693, 2009.

COUGOUlE, C.; VAN GOETHEM, E.; LE CABEC, V.; LAFOURESSE, F.; DUPRÉ, L.; MEHRAJ, V.; MÈGE, J. L.; LASTRUCCI, C.; MARIDONNEAU-PARINI, I. Blood leukocytes and macrophages of various phenotypes have distinct abilities to form podosomes and to migrate in 3D environments. Eur. J. Cell. Biol., v. 91, n. 12, p. 938-949, 2012.

CYSTER, J. G. Chemokines, sphingosine-1-phosphate, and cell migration in secondary lymphoid organs. Annu. Rev. Immunol., v. 23, p. 127-159, 2005.

DANGLES-MARIE, V.; RICHON, S.; EL-BEHI, M.; ECHCHAKIR, H.; DOROTHÉE, G.; THIERY, J.; VALIDIRE, P.; VERGNON, I.; MENEZ, J.; LADJIMI, M.; CHOUAIB, S.; BELLET, D.; MAMI-CHOUAIB, F. A three-dimensional tumor cell defect in activating autologous CTLs is associated with inefficient antigen presentation correlated with heat shock protein-70 down-regulation. Cancer Res., v. 63, n. 13, p. 3682-3687, 2003.

DAVIDSON, B.; ELSTRAND, M. B.; MCMASTER, M. T.; BERNER, A.; KURMAN, R. J.; RISBERG, B.; TROPE, C. G.; SHIH, I. E. M. HLA-G expression in effusions is a possible 
marker of tumor susceptibility to chemotherapy in ovarian carcinoma. Gynecol. Oncol., v. 96, n. 1, p. 42-47, 2005.

DEBNATH, J.; BRUGGE, J. S.; Modelling glandular epithelial cancers in three-dimensional cultures. Nat. Rev. Cancer., v. 5, n. 9, p. 675-688, 2005.

DHIMOLEA, E.; MAFFINI, M. V.; SOTO, A. M.; SONNENSCHEIN, C. The role of collagen reorganization on mammary epithelial morphogenesis in a $3 \mathrm{D}$ culture model. Biomaterials.,v. 2 n. 13, p. 3622-3630, 2010.

DIEU, M. C.; VANBERVLIET, B.; VICARI, A.; BRIDON, J. M.; OLDHAM, E.; AÏTYAHIA, S.; BRIÈRE, F.; ZLOTNIK, A.; LEBECQUE, S.; CAUX, C. Selective recruitment of immature and mature dendritic cells by distinct chemokines expressed in different anatomic sites. J. Cell Sci., v. 15, n. 116, p. 2377-2388, 2003.

Dorj, B.; Won, J. E.; Purevdorj, O.; Patel, K. D.; Kim, J. H.; Lee, E. J.; Kim, H. W. A novel therapeutic design of microporous-structured biopolymer scaffolds for drug loading and delivery. Acta. Biomater., v. 13, p. 1742-7061, 2013.

DORNER, B.; MÜLLER, S.; ENTSCHLADEN, F.; SCHRÖDER, J. M.; FRANKE, P.; KRAFT, R.; FRIEDL, P.; CLARK-LEWIS, I.; KROCZEK, R. A. Purification, structural analysis, and function of natural ATAC, a cytokine secreted by CD8(+) T cells. J. Biol. Chem., v. 272, n. 13, p. 8817-8823, 1997.

DUTTA, N.; MAJUMDER, D.; GUPTA, A.; MAZUMDER, D. N.; BANERJEE, S. Analysis of human lymphocyte antigen class I expression in gastric cancer by reverse transcriptasepolymerase chain reaction. Hum. Immunol., v. 66, n. 2, p. 164-169, 2005.

DUTTA, R. C.; DUTTA, A. K. Cell-interactive 3D-scaffold; advances and applications. Biotechnol. Adv., v. 27, n. 4, p. 334-339, 2009.

DZOPALIC, T.; RAJKOVIC, I.; DRAGICEVIC, A.; COLIC, M. The response of human dendritic cells to co-ligation of pattern-recognition receptors. Immunol. Res., v. 52, n. 2, p. 20-33, 2012.

EISENDLE, K.; WOLF, D.; GASTL, G.; KIRCHER-EIBL, B. Dendritic cells from patients with chronic myeloid leukemia: functional and phenotypic features. Leuk. Lymphoma., v. 46, n. 5, p. 663-670, 2005.

ENGERING, A.; GEIJTENBEEK, T. B.; VAN VLIET, S. J.; WIJERS, M.; VAN LIEMPT, E.; DEMAUREX, N.; LANZAVECCHIA, A.; FRANSEN, J.; FIGDOR, C. G.; PIGUET, V.; VAN KOOYK, Y. The dendritic cell-specific adhesion receptor DC-SIGN internalizes antigen for presentation to T cells. J. Immunol., v. 168, n. 5, p. 2118-2126, 2002.

ENTSCHLADEN, F.; NIGGEMANN, B.; ZÄNKER, K. S.; FRIEDL, P. Differential requirement of protein tyrosine kinases and protein kinase $\mathrm{C}$ in the regulation of $\mathrm{T}$ cell locomotion in three-dimensional collagen matrices. J. Immunol., v. 159, n. 7, p. 3203-3210, 1997.

FAVIER, B.; LEMAOULT, J.; ROUAS-FREISS, N.; MOREAU, P.; MENIER, C.; CAROSELLA, E. 
D. Research on HLA-G: an update. Tissue Antigens., v. 69, n. 3, p. 207-211, 2007.

FEDER-MENGUS, C.; GHOSH, S.; RESCHNER, A.; MARTIN, I.; SPAGNOLI, G. C. New dimensions in tumor immunology: what does 3D culture reveal? Trends Mol. Med., v. 14, n. 8, p. 333-340, 2008.

FEDER-MENGUS, C.; GHOSH, S.; WEBER, W. P.; WYLER, S.; ZAJAC, P.; TERRACCIANO, L.; OERTLI, D.; HEBERER, M.; MARTIN, I.; SPAGNOLI, G. C.; RESCHNER, A. Multiple mechanisms underlie defective recognition of melanoma cells cultured in three-dimensional architectures by antigen- specific cytotoxic T lymphocytes. Br. J. Cancer., v. 96. n. 7, p. 1072-1082, 2007.

FENG, C. H.; CHENG, Y. C.; CHAO, P. H. The influence and interactions of substrate thickness, organization and dimensionality on cell morphology and migration. Acta. Biomater., v. 9, n. 3, p. 5502-5510, 2013.

FISCHER, K.; HOFFMANN, P.; VOELKL, S.; MEIDENBAUER, N.; AMMER, J.; EDINGER, M.; GOTTFRIED, E.; SCHWARZ, S.; ROTHE, G.; HOVES, S.; RENNER, K.; TIMISCHL, B.; MACKENSEN, A.; KUNZ-SCHUGHART, L.; ANDREESEN, R.; KRAUSE, S. W.; KREUTZ, M. Inhibitory effect of tumor cell-derived lactic acid on human T cells. Blood., v. 109, n. 9, p. 3812-3819, 2007.

FREITAS, V. M.; JAEGER, R. G. The effect of laminin and its peptide SIKVAV on a human salivary gland adenoid cystic carcinoma cell line. Virchows Arch., v. 441, n. 6, p. 569-576, 2002.

FREITAS, V. M.; RANGEL, M.; BISSON, L. F.; JAEGER, R. G.; MACHADO-SANTELLI, G. M. The geodiamolide $\mathrm{H}$, derived from Brazilian sponge Geodia corticostylifera, regulates actin cytoskeleton, migration and invasion of breast cancer cells cultured in three-dimensional environment. J. Cell Physiol., v. 216, n. 3, p. 583-594, 2008.

FRIEDL, P.; BRÖCKER, E. B. Reconstructing leukocyte migration in 3D extracellular matrix by time-lapse videomicroscopy and computer-assisted tracking. Methods Mol. Biol., v. 239, n. 23, p. 77-90, 2004.

FRIEDL, P.; ENTSCHLADEN, F.; CONRAD, C.; NIGGEMANN, B.; ZÄNKER, K. S. $\mathrm{CD} 4+\mathrm{T}$ lymphocytes migrating in three-dimensional collagen lattices lack focal adhesions and utilize betal integrin-independent strategies for polarization, interaction with collagen fibers and locomotion. Eur. J. Immunol., v. 28, p. 2331- 2343, 1998.

FRIEDL, P.; GUNZER, M.; Interaction of T cells with APCs: the serial encounter model. Trends Immunol., v. 22, n. 4, p. 187-191,2001.

FRIEDL, P.; NOBLE, P. B.; SHIELDS, E. D.; ZÄNKER, K. S. Locomotor phenotypes of unstimulated CD45RAhigh and CD45ROhigh CD4+ and CD8+ lymphocytes in threedimensional collagen lattices. Immunology., v. 82, n. 617-624, 1994.

FRIEDL, P.; NOBLE, P. B.; ZÄNKER, K. S. Lymphocyte migration in three-dimensional collagen gels. Comparison of three quantitative methods for analysing cell trajectories. $\mathbf{J}$. Immunol. Meth., v. 165, p. 157-165, 1993. 
GANGULY, D.; HAAK, S.; SISIRAK, V.; REIZIS, B. The role of dendritic cells in autoimmunity. Nat. Rev. Immunol., v. 13, n. 8, p. 566-577, 2013.

GEIJTENBEEK, T. B.; TORENSMA, R.; VAN VLIET, S. J.; VAN DUIJNHOVEN, G. C.; ADEMA, G. J.; VAN KOOYK, Y.; FIGDOR, C. G. Identification of DC-SIGN, a novel dendritic cell-specific ICAM-3 receptor that supports primary immune responses. Cell., v. 100, n. 5 , p. 575-585, 2000.

GHOSH. S.; ROSENTHAL, R.; ZAJAC, P.; WEBER, W. P.; OERTLI, D.; HEBERER, M.; MARTIN, I.; SPAGNOLI, G.C.; RESCHNER, A. Culture of melanoma cells in 3dimensional architectures results in impaired immunorecognition by cytotoxic $\mathrm{T}$ lymphocytes specific for Melan-A/MART-1 tumor- associated antigen. Ann. Surg., v. 242, n. 6, p. 851$857,2005$.

GONZÁlEZ, B.; SOLANO-AGAMA MDEL, C.; GONZÁLEZ DEL PLIEGO, M.; MENDOZA-GARRIDO, M. E. Differences in cell migration of cultured pituitary cells from infantile and adult rats: participation of the extracellular matrix and epidermal growth factor. Int. J. Dev. Neurosci., v. 22, n. 4, p. 231-239, 2004.

GRETZ, J. E.; ANDERSON, A. O.; SHAW, S. Cords, channels, corridors and conduits: critical architectural elements facilitating cell interactions in the lymph node cortex. Immunol. Rev., v. 156, p. 11-24, 1997.

GRIFFITH, L. G.; SWARTZ, M. A. Capturing complex 3D tissue physiology in vitro. Nat. Rev. Mol. Cell Biol., v.7, n. 3, p. 211-224, 2006.

GUERMONPREZ, P.; VALLADEAU, J.; ZITVOGEL, L.; THÉRY, C.; AMIGORENA, S. Antigen presentation and $\mathrm{T}$ cell stimulation by dendritic cells. Annu. Rev. Immunol., v. 20, p. 621-667, 2002.

GUNZER, M.; FRIEDL, P.; NIGGEMANN, B.; BRÖCKER, E. B.; KÄMPGEN, E.; ZÄNKER, K. S. Migration of dendritic cells within 3-D collagen lattices is dependent on tissue origin, state of maturation, and matrix structure and is maintained by proinflammatory cytokines. J. Leukoc. Biol., v. 67, n. 5, p. 622-629, 2000a.

GUNZER, M.; SCHÄFER, A.; BORGMANN, S.; GRABBE， S.; ZÄNKER, K. S.; BRÖCKER, E. B.; KÄMPGEN, E.; FRIEDL, P. Antigen presentation in extracellular matrix: interactions of $\mathrm{T}$ cells with dendritic cells are dynamic, short lived, and sequential. Immunity., v. 13, n. 3, p. 323-332, 2000 b.

HACHEHOUCHE, L. N.; CHETOUI, N.; AOUDJIT, F.; Implication of discoidin domain receptor 1 in $\mathrm{T}$ cell migration in three-dimensional collagen. Mol. Immunol., v. 47, n. 9, p. 866-869, 2010.

HARKIN, D. G.; HAY, E. D. Effects of electroporation on the tubulin cytoskeleton and directed migration of corneal fibroblasts cultured within collagen matrices. Cell Motil. Cytoskeleton., v. 35, n. 4, p. 345-357, 1996. 
HERRMANN, F.; LEHR, H. A.; DREXLER, I.; SUTTER, G.; HENGSTLER, J.; WOLLSCHEID, U.; SELIGER, B. HER-2/neu-mediated regulation of components of the MHC class I antigen-processing pathway. Cancer Res., v. 64, n. 1, p. 215-220, 2004.

HIRANO, N.; BUTLER, M .O.; XIA, Z.; ANSEN, S.; VON BERGWELT-BAILDON, M. S.; NEUBERG, D.; FREEMAN, G. J., NADLER, L. M. Engagement of CD83 ligand induces prolonged expansion of CD8 $+\mathrm{T}$ cells and preferential enrichment for antigen specificity. Blood., v. 107, p. 1528-1536, 2006.

HOLMES, B.; CASTRO, N. J.; LI, J.; KEIDAR, M.; ZHANG, L. G. Enhanced human bone marrow mesenchymal stem cell functions in novel 3D cartilage scaffolds with hydrogen treated multi-walled carbon nanotubes. Nanotechnology., v. 24, n. 36, p. 365-400, 2013.

HUGHES, G.C.; CLARK, E. A. Regulation of dendritic cells by female sex steroids: relevance to immunity and autoimmunity. Autoimmunity., v. 40, n. 6, p. 470-481, 2007.

IBRAHIM, E. C.; ARACTINGI, S.; ALLORY, Y.; BORRINI, F.; DUPUY, A.; DUVILlARD, P.; CAROSELlA, E. D.; AVRIL, M. F.; PAUL, P. Analysis of HLA antigen expression in benign and malignant melanocytic lesions reveals that upregulation of HLA-G expression correlates with malignant transformation, high inflammatory infiltration and HLAA1 genotype. Int. J. Cancer., v. 108, n. 2, p. 243-250, 2004.

IBRAHIM, E. C.; GUERRA, N.; LACOMBE, M. J.; ANGEVIN, E.; CHOUAIB, S.; CAROSELlA, E. D.; CAIGNARD, A.; PAUL, P. Tumor-specific up-regulation of the nonclassical class I HLA-G antigen expression in renal carcinoma. Cancer Res., v. 61, n. 18, p. 6838-6845, 2001.

IEZZI, G.; KARJALAINEN, K.; LANZAVECCHIA, A. The duration of antigenic stimulation determines the fate of naive and effector T cells. Immunity., v. 8, n. 1, p. 89-95, 1998.

ILINA, O.; BAKKER, G. J.; VASATURO, A.; HOFMANN, R. M.; FRIEDL, P. Two-photon laser-generated microtracks in 3D collagen lattices: principles of MMP-dependent and independent collective cancer cell invasion. Phys. Biol., v. 8, n. 1, p. 15-19, 2011.

INGBER, D. E.; DIKE, L.; HANSEN, L.; KARP, S.; LILEY, H.; MANIOTIS, A.; MCNAMEE, H.; MOONEY, D.; PLOPPER, G.; SIMS, J. Cellular tensegrity: exploring how mechanical changes in the cytoskeleton regulate cell growth, migration, and tissue pattern during morphogenesis. Int. Rev. Cytol., v. 150, n. 77, p. 173-224, 1994.

INGULLI, E.; MONDINO, A.; KHORUTS, A.; JENKINS, M. K. In vivo detection of dendritic cell antigen presentation to CD4(+) T cells. J. Exp. Med., v. 185, n. 12, p. 2133-41, 1997.

INSTITUTO NACIONAL DO CÂNCER. Disponivel em:

$<$ http://www2.inca.gov.br/wps/wcm/connect/tiposdecancer/site/home/mama $>$. Acesso em: 9 Março 2013.

JEONG, S.; PARK ,S.; PARK, B. W.; PARK, Y.; KWON, O. J.; KIM, H. S. Human leukocyte antigen-G (HLA-G) polymorphism and expression in breast cancer patients._PLoS 
One, v. 9, n. 5, p. 982-989, 2014.

JOHNSTONE, R. M.; ADAM, M.; HAMMOND, J. R.; ORR, L.; TURBIDE, C. Vesicle formation during reticulocyte maturation. Association of plasma membrane activities with released vesicles (exosomes). J. Biol. Chem., v. 262, n. 19, p. 9412-9420, 1987.

KALDJIAN, E. P.; GRETZ, J. E.; ANDERSON, A. O.; SHI, Y.; SHAW, S. Spatial and molecular organization of lymph node $\mathrm{T}$ cell cortex: a labyrinthine cavity bounded by an epithelium-like monolayer of fibroblastic reticular cells anchored to basement membrane-like extracellular matrix. Int. Immunol., v. 13, n. 10, p. 1243-1253, 2001.

KANEKO, K.; ISHIGAMI, S.; KIJIMA, Y.; FUNASAKO, Y.; HIRATA, M.; OKUMURA, H.; SHINCHI, H.; KORIYAMA, C.; UENO, S.; YOSHINAKA, H.; NATSUGOE, S. Clinical implication of HLA class I expression in breast cancer. BMC Cancer., v. 11, n. 6, p. 454-450, 2011.

KANTHOU, C.; KRANJC, S.; SERSA, G.; TOZER, G.; ZUPANIC, A.; CEMAZAR, M. The endothelial cytoskeleton as a target of electroporation-based therapies. Mol. Cancer Ther., v. 5, n. 12, p. 3145-3152, 2006.

Karttunen, T.; Sormunen, R.; Risteli, L.; Risteli, J.; Autio-Harmainen, H. Immunoelectron microscopic localization of laminin, type IV collagen, and type III $\mathrm{pN}$-collagen in reticular fibers of human lymph nodes. J. Histochem. Cytochem., v. 37, n. 3, p. 279-286, 1989.

KIERTSCHER, S. M.; ROTH, M. D. Human CD14+ leukocytes acquire the phenotype and function of antigen-presenting dendritic cells when cultured in GM-CSF and IL-4. J. Leukoc. Biol., v. 59, n. 2, p. 208-218, 1996.

KIM, C. H.; HONG, M. J.; PARK, S. D.; KIM, C. K.; PARK, M. Y.; SOHN, H. J.; CHO, H. I.; KIM, T. G.; HONG, Y. K. Enhancement of anti-tumor immunity specific to murine glioma by vaccination with tumor cell lysate-pulsed dendritic cells engineered to produce interleukin12. Cancer Immunol. Immunother., v. 55, n. 11, p. 1309-1319, 2006.

KLEINMAN, H. K.; MARTIN, G. R. Matrigel: basement membrane matrix with biological activity. Semin. Cancer Biol., v. 15, n. 5, p. 378-386, 2005.

KOYA, R. C.; WEBER, J. S.; KASAHARA, N.; LAU, R.; VILLACRES, M. C.; LEVINE, A. M.; STRIPECKE, R. Making dendritic cells from the inside out: lentiviral vector-mediated gene delivery of granulocyte- macrophage colony-stimulating factor and interleukin 4 into CD14+ monocytes generates dendritic cells in vitro. Hum. Gene Ther., v. 15, n. 8, p. 733$748,2004$.

KRAMER, R. H,; ROSEN, S. D.; MCDONALD, K. A. Basement-membrane components associated with the extracellular matrix of the lymph node. Cell Tissue Res., v. 252, n. 2, p. 367-375, 1988.

KUROTAKI, T.; TAMURA, Y.; UEDA, G.; OURA, J.; KUTOMI, G.; HIROHASHI, Y.; SAHARA, H.; TORIGOE, T.; HIRATSUKA, H.; SUNAKAWA, H.; HIRATA, K.; SATO, $\mathrm{N}$. Efficient cross-presentation by heat shock protein 90-peptide complex-loaded dendritic cells via an endosomal pathway. J. Immunol., v. 179, n. 3, p. 1803-1813, 2007. 
LAURENCE, A.; TATO, C. M.; DAVIDSON, T. S.; KANNO, Y.; CHEN, Z.; YAO, Z.; BLANK, R. B.; MEYLAN, F.; SIEGEL, R.; HENNIGHAUSEN, L.; SHEVACH, E. M.; O'SHEA, J. J. Interleukin-2 signaling via STAT5 constrains T helper 17 cell generation. Immunity., v. 26, n. 3, p. 371-381, 2007.

LE BOUTEILlER, P.; SOLIER, C.; PRÖLL, J.; AGUERRE-GIRR, M.; FOURNEL, S, LENFANT, F. Placental HLA-G protein expression in vivo: where and what for? Hum. Reprod. Update., v. 5, n. 3, p. 223-233, 1999.

LECHMANN, M.; KROOSHOOP, D. J.; DUDZIAK, D.; KREMMER, E.; KUHNT, C.; FIGDOR, C. G.; SCHULER, G.; STEINKASSERER, A. The extracellular domain of CD83 inhibits dendritic cell- mediated $\mathrm{T}$ cell stimulation and binds to a ligand on dendritic cells. $\mathbf{J}$. Exp. Med., v. 194, p. 1813-1821, 2001.

LEE, E. Y.; LEE, W. H.; KAETZEL, C. S.; PARRY, G.; BISSELL, M. J. Interaction of mouse mammary epithelial cells with collagen substrata: regulation of casein gene expression and secretion. Proc. Natl. Acad. Sci U S A., v. 82, n. 5, p. 1419-1423, 1985.

LEE, J.; CUDDIHY, M. J.; KOTOV, N. A. Three-dimensional cell culture matrices: state of the art. Tissue Eng. Part. B Rev., v. 14, n. 1, p. 61-86, 2008.

LEE, K. H.; HOLDORF, A. D.; DUSTIN, M. L.; CHAN, A. C.; ALLEN, P. M.; SHAW, A. S. T cell receptor signaling precedes immunological synapse formation. Science., v. 295, n. 5559, p. 1539-1542, 2002.

LENARDO, M.; CHAN, K. M.; HORNUNG, F.; MCFARLAND, H.; SIEGEL, R.; WANG, J.; ZHENG, L. Mature T lymphocyte apoptosis--immune regulation in a dynamic and unpredictable antigenic environment. Annu. Rev. Immunol., n. 17, p. 221-253, 1999.

LI, W.; MU, D.; TIAN, F.; HU, Y.; JIANG, T.; HAN, Y.; CHEN, J.; HAN, G.; LI, X. Exosomes derived from Rab27a-overexpressing tumor cells elicit efficient induction of antitumor immunity. Mol. Med. Rep., v. 8, n. 6, p. 1876-1882, 2013.

LIAO, W.; SCHONES, D. E.; OH, J.; CUI, Y.; CUI, K.; ROH, T. Y.; ZHAO, K.; LEONARD W. J. Priming for $\mathrm{T}$ helper type 2 differentiation by interleukin 2-mediated induction of interleukin 4 receptor alpha-chain expression. Nat. Immunol., v. 9, n. 11, p. 1288-1296, 2008.

LIAO, W.; LIN, J. X.; LEONARD, W. J. IL-2 family cytokines: new insights into the complex roles of IL-2 as a broad regulator of $\mathrm{T}$ helper cell differentiation. Curr. Opin. Immunol., v. 23, n. 5, p. 598-604, 2011.

LIU, Y. J. Professional type 1 interferon-producing cells and plasmacytoid dendritic cell precursors. Annu. Rev. Immunol., v. 23, n. 78, p. 275-306, 2005.

LOUMAGNE $\mathrm{L}^{1}$, BAUDHUIN J, FAVIER B, MONTESPAN F, CAROSELLA ED, ROUAS-FREISS N. In vivo evidence that secretion of HLA-G by immunogenic tumor cells allows their evasion from immunosurveillance. Int. J. Cancer., v. 135, n. 9, p. 2107-2117, 2014. 
MAYORDOMO, J. I.; ZORINA, T.; STORKUS, W. J.; ZITVOGEL, L.; CELLUZZI, C.; FALO, L. D.; MELIEF, C. J.; ILDSTAD, S. T.; KAST, W. M.; DELEO, A. B. Bone marrowderived dendritic cells pulsed with synthetic tumour peptides elicit protective and therapeutic antitumour immunity. Nat. Med., v. 1, n. 12, p. 1297-1302, 1995.

MEMPEL, T. R.; HENRICKSON, S. E.; VON ANDRIAN, U. H. T-cell proming by dendritic cells in lymph nodes occurs in three distinct phases. Nature., v. 427, n. 76, p. 154-159, 2004.

MILLER, M. J.; WEI, S. H.; PARKER, I.; CAHALAN, M. D. Two-photon imaging of lymphocyte motility and antigen response in intact lymph node. Science., v. 296, n. 5574, p. 1869-1873, 2002.

MONTES, G. S.; JUNQUEIRA, L. C. The use of the Picrosirius-polarization method for the study of the biopathology of collagen. Mem. Inst. Oswaldo Cruz., v. 86, n. 3, p. 1-11, 1991.

NAIK, S. H. Demystifying the development of dendritic cell subtypes, a little. Immunol. Cell. Biol., v. 86, n. 5, p. 439-452, 2008.

NAITO, H.; TOJO, T.; KIMURA, M.; DOHI, Y.; ZIMMERMANN, W. H.; ESCHENHAGEN, T.; TANIGUCHI, S. Engineering bioartificial tracheal tissue using hybrid fibroblast-mesenchymal stem cell cultures in collagen hydrogels. Interact. Cardiovasc. Thorac. Surg., v. 12, n. 2, p. 156-161, 2011.

NEVES, A.R.; ENSINA, L. F.; ANSELMO, L. B.; LEITE, K. R.; BUZAID, A. C.; CÂMARA-LOPES, L. H.; BARBUTO, J. A. Dendritic cells derived from metastatic cancer patients vaccinated with allogeneic dendritic cell-autologous tumor cell hybrids express more CD86 and induce higher levels of interferon-gamma in mixed lymphocyte reactions. Cancer Immunol. Immunother., v. 54, n. 1, p. 61-66, 2005.

NIU, B. L.; DU, H. M.; SHEN, H. P.; LIAN, Z. R.; LI, J. Z.; LAI, X.; WEI, S. D.; ZOU, L. Q.; GONG, J. P. Myeloid dendritic cells loaded with dendritic tandem multiple antigenic telomerase reverse transcriptase (hTERT) epitope peptides: a potentially promising tumor vaccine. Vaccine., v. 30, n. 23, p. 3395-3404, 2012.

NUSSENZWEIG, M. C.; STEINMAN, R. M. Contribution of dendritic cells to stimulation of the murine syngeneic mixed leukocyte reaction. J. Exp. Med., v. 151, n. 5, p. 1196-1212, 1980.

O'DOHERTY, U.; PENG, M.; GEZELTER, S.; SWIGGARD, W. J.; BETJES, M.; BHARDWAJ, N.; STEINMAN, R. M. Human blood contains two subsets of dendritic cells, one immunologically mature and the other immature. Immunology., v. 82, n. 3, p. 487-493, 1994.

OJIMA, T.; IWAHASHI, M.; NAKAMURA, M.; MATSUDA, K.; NAKA, T.; NAKAMORI, M.; UEDA, K.; ISHIDA, K.; YAMAUE, H. The boosting effect of co-transduction with cytokine genes on cancer vaccine therapy using genetically modified dendritic cells expressing tumor-associated antigen. Int. J. Oncol., v. 28, n. 4, p. 947-953, 2006.

ORSINI, G.; LEGITIMO, A.; FAILLI, A.; FERRARI, P.; NICOLINI, A.; SPISNI, R.; MICCOLI, P.; CONSOLINI, R. Defective Generation and Maturation of Dendritic Cells from 
Monocytes in Colorectal Cancer Patients during the Course of Disease. Int. J. Mol. Sci., v. 14, n. 11, p. 22022-22041, 2013.

PAGE, H.; FLOOD, P.; REYNAUD, E. G. Three-dimensional tissue cultures: current trends and beyond. Cell Tissue Res., v. 352, n. 1, p. 123-131, 2013.

PINHO, M. P.; MIGLIORI, I. K.; FLATOW, E. A.; BARBUTO, J. A. Dendritic cell membrane CD83 enhances immune responses by boosting intracellular calcium release in $\mathrm{T}$ lymphocytes. J. Leukoc. Biol., . v. 56, n. 8, p. 1237-1255, 2014.

PRZEPIORKA, D.; SRIVASTAVA, P. K. Heat shock protein--peptide complexes as immunotherapy for human cancer. Mol. Med. Today., v. 4, n. 11, p. 478-484, 1998.

PULENDRAN, B. Modulating TH1/TH2 responses with microbes, dendritic cells, and pathogen recognition receptors. Immunol. Res., v. 29, n. 3, p. 187-196, 2004.

RAMOS, C. S.; GONÇALVES, A. S.; MARINHO, L. C.; GOMES AVELINO, M. A.; SADDI, V. A.; LOPES, A. C.; SIMÕES, R. T.; WASTOWSKI, I. J. Analysis of HLA-G gene polymorphism and protein expression in invasive breast ductal carcinoma. Hum. Immunol., v. 75, n. 7, p. 667-672, 2014.

RAMOS, R. N.; CHIN, L. S.; DOS SANTOS, A. P.; BERGAMI-SANTOS, P. C.; LAGINHA, F.; BARBUTO, J. A. Monocyte-derived dendritic cells from breast cancer patients are biased to induce CD4+CD25+Foxp3+ regulatory T cells. J. Leukoc. Biol., v. 92, n. 3, p. 673-682, 2012.

RANGARAJAN, A.; HONG, S. J.; GIFFORD, A.; WEINBERG, R. A. Species- and cell type-specific requirements for cellular transformation. Cancer Cell., v. 6, n. 2, p. 171-183, 2004.

RAO, W. H.; HALES, J. M.; CAMP, R. D.; Potent costimulation of effector T lymphocytes by human collagen type I. J. Immunol., v. 165, n. 9, p. 4935-4940, 2000.

REICHARDT, P.; GUNZER, F.; GUNZER, M. Analyzing the physicodynamics of immune cells in a three-dimensional collagen matrix. Methods Mol Biol., v. 380, n. 90, p. 253-269, 2007.

REIZIS, B.; COLONNA, M.; TRINCHIERI, G.; BARRAT, F.; GILLIET, M. Plasmacytoid dendritic cells: one-trick ponies or workhorses of the immune system? Nat. Rev. Immunol,. v. 11, n. 8, p. 558-565, 2011.

REYES, D.; SALAZAR, L.; ESPINOZA, E.; PEREDA, C.; CASTELLÓN, E.; VALDEVENITO, R.; HUIDOBRO, C.; INÉS BECKER, M.; LLADSER, A.; LÓPEZ, M. N.; SALAZAR-ONFRAY, F. Tumour cell lysate-loaded dendritic cell vaccine induces biochemical and memory immune response in castration-resistant prostate cancer patients. Br. J. Cancer., v. 109, n. 6, p. 1488-1497, 2013.

REZK, S. A.; NATHWANI, B. N.; ZHAO, X.; WEISS, L. M. Follicular dendritic cells: origin, function, and different disease-associated patterns. Hum. Pathol., v. 44, n. 6, p. $937-$ 950, 2013. 
ROMAGNOLI, G. G. Exossomos derivados de células dendríticas como adjuvantes naturais na resposta antitumoral. 2012. $142 \mathrm{f}$. Tese (Doutorado em Imunologia) - Instituto de Ciências Biomédicas, Universidade de São Paulo, São Paulo, 2012.

ROSALIA, R. A.; QUAKKELAAR, E. D.; REDEKER, A.; KHAN, S.; CAMPS, M.; DRIJFHOUT, J. W.; SILVA, A. L.; JISKOOT W. Dendritic cells process synthetic long peptides better than whole protein, improving antigen presentation and T-cell activation. Eur. J. Immunol., v. 43, n. 10, p. 2554-2565, 2013.

ROSENBLATT, J.; AVIVI, I.; VASIR, B.; UHL, L.; MUNSHI, N. C.; KATZ, T.; DEY, B. R.; SOMAIYA, P.; MILLS, H. Vaccination with dendritic cell/tumor fusions following autologous stem cell transplant induces immunologic and clinical responses in multiple myeloma patients. Clin Cancer Res,. v. 19, n. 13, p. 3640-3648, 2013.

ROSKELLEY, C. D.; DESPREZ, P.Y.; BISSELL, M. J. Extracellular matrix-dependent tissue-specific gene expression in mammary epithelial cells requires both physical and biochemical signal transduction. Proc. Natl. Acad. Sci U S A., v. 91, n. 26, p. 12378-12382, 1994.

SAEKI, H.; MOORE, A. M.; BROWN, M. J.; HWANG, S. T. Cutting edge: secondary lymphoid-tissue chemokine (SLC) and CC chemokine receptor 7 (CCR7) participate in the emigration pathway of mature dendritic cells from the skin to regional lymph nodes. $\mathbf{J}$. Immunol., n. 1,62 v. 5, p. 2472-2475, 1999.

SALLUSTO, F.; SCHAERLI, P.; LOETSCHER, P.; SCHANIEL, C.; LENIG, D.; MACKAY, C. R.; QIN, S.; LANZAVECCHIA, A. Rapid and coordinated switch in chemokine receptor expression during dendritic cell maturation. Eur. J. Immunol., v. 28, n. 9, p. 2760-2769, 1998.

SALLUSTO, F1.; LANZAVECCHIA, A. Efficient presentation of soluble antigen by cultured human dendritic cells is maintained by granulocyte/macrophage colony-stimulating factor plus interleukin 4 and downregulated by tumor necrosis factor alpha. J. Exp. Med., v. 79, n. 4, p. 1109-1118, 1994.

SANTINI, M. T.; RAINALDI, G.; ROMANO, R.; FERRANTE, A.; CLEMENTE, S.; MOTTA, A.; INDOVINA, P. L. MG- 63 human osteosarcoma cells grown in monolayer and as three-dimensional tumor spheroids present a different metabolic profile: a (1)H NMR study. FEBS. Lett., v. 557, n. 3, p. 148-154, 2004, 2004.

SATO, K.; FUJITA, S. Dendritic cells: nature and classification. Allergol. Int., v. 56, n. 3, p. 183-191, 2007.

SCHMEICHEL, K. L.; BISSELL, M. J. Modeling tissue-specific signaling and organ function in three dimensions. J. Cell Sci., v. 116, n. 12, p. 2377-2388, 2003.

SCHMIDT, S.; FRIEDL, P. Interstitial cell migration: integrin-dependent and alternative adhesion mechanisms. Cell Tissue Res., v. 339, n. 1, p. 83-92, 2010.

SCHULER, G.; STEINMAN, R. M. Murine epidermal Langerhans cells mature into potent immunostimulatory dendritic cells in vitro. J. Exp. Med., v. 161, n. 3, p. 526-546, 1995. 
SCHUPPAN, D.; RÜHL, M. Matrix in signal transduction and growth factor modulation. Braz. J. Med. Biol. Res., v. 27, n. 9, p. 2125-2141, 1994.

SCOTT-TAYLOR, T.; PETTENGELL, R.; CLARKE, I.; STUHLER, G.; LA BARTHE, M.; WALDEN, P.; DALGLEISH, A. Human tumour and dendritic cell hybrids generated by electrofusion: potential for cancer vaccines. Biochim. Biophys. Acta., v. 1500, n. 3, p. 265$279,2000$.

SELIGER, B. Molecular mechanisms of MHC class I abnormalities and APM components in human tumors. Cancer Immunol. Immunother., v. 57, n. 11, p. 1719-1726, 2008.

SERHAL, K.; BAILLOU, C.; GHINEA, N.; FONTANGES, P.; DUPUY, F. P.; LEMOINE, F. M.; LACAVE, R. Characteristics of hybrid cells obtained by dendritic cell/tumour cell fusion in a T-47D breast cancer cell line model indicate their potential as anti-tumour vaccines. Int. J. Oncol., v. 31, n. 6, p. 1357-1365, 2007.

SERTL, K.; TAKEMURA, T.; TSCHACHLER, E.; FERRANS, V. J.; KALINER, M. A.; SHEVACH, E. M. Dendritic cells with antigen-presenting capability reside in airway epithelium, lung parenchyma, and visceral pleura. J Exp Med., v. 163, n. 2, p. 436-451, 1986.

SHAW, K. R.; WROBEL, C. N.; BRUGGE, J. S. Use of three-dimensional basement membrane cultures to model oncogene-induced changes in mammary epithelial morphogenesis. J. Mammary Gland Biol. Neoplasia., v. 9, n. 4, p. 297-310, 2004.

SHEVACH, E. M. Mechanisms of foxp3 $\mathrm{T}$ regulatory cell-mediated suppression. Immunity., v. 30, n. 5, p. 636-645, 2009.

SHIROISHI, M.; TSUMOTO, K.; AMANO, K.; SHIRAKIHARA, Y.; COLONNA, M.; BRAUD, V. M.; ALLAN, D. S.; MAKADZANGE, A. Human inhibitory receptors Ig-like transcript 2 (ILT2) and ILT4 compete with CD8 for MHC class I binding and bind preferentially to HLA-G. Proc. Natl. Acad. Sci U S A., v. 100, n. 15, p. 8856-8861, 2003.

SIXT, M.; LÄMMERMANN, T. In vitro analysis of chemotactic leukocyte migration in 3D environments. Methods Mol. Biol., v. 769, n. 77, p. 149-146, 2011.

SOBOCINSKI, G. P.; TOY, K.; BOBROWSKI, W. F.; SHAW, S.; ANDERSON, A. O.; KALDJIAN, E. P. Ultrastructural localization of extracellular matrix proteins of the lymph node cortex: evidence supporting the reticular network as a pathway for lymphocyte migration. BMC. Immunol., v. 17, n. 12, p. 11-42, 2010.

SOLOMON, S.; MASILAMANI, M.; MOHANTY, S.; SCHWAB, J. E.; BONEBERG, E. M.; ILLGES, H. Generation of three-dimensional pannus-like tissues in vitro from single cell suspensions of synovial fluid cells from arthritis patients. Rheumatol. Int., v. 24, n. 2, p. 71 76, 2004.

SOMASUNDARAM, R.; RUEHL, M.; TILING, N.; ACKERMANN, R.; SCHMID, M.; RIECKEN, E. O.; SCHUPPAN, D. Collagens serve as an extracellular store of bioactive interleukin 2. J. Biol. Chem., v. 275, n. 49, p. 38170-38175, 2000. 
STEINMAN, R. M. The dendritic cell system and its role in immunogenicity. Annu. Rev. Immunol., v. 9, p. 271-296, 1991.

STEINMAN, R. M.; COHN, Z. A. Identification of a novel cell type in peripheral lymphoid organs of mice. I. Morphology, quantitation, tissue distribution. J. Exp. Med., v. 137, n. 5, p. 1142-1162, 1973.

STEINMAN, R. M.; WITMER, M. D. Lymphoid dendritic cells are potent stimulators of the primary mixed leukocyte reaction in mice. Proc. Natl. Acad. Sci U S A, v. 75, n. 10, p. $5132-$ 5136, 1978.

STEPONAVICIUS-CRUZ, K.; FREITAS, V. M.; BARBUTO, J. A. Dendritic cells and T lymphocytes interactions in a novel 3D system. Procedia Engineering., v. 59, p. 166-173, 2013.

STERN, M. M.; MYERS, R. L.; HAMMAM, N.; STERN, K. A.; EBERLI, D.; KRITCHEVSKY, S. B.; SOKER, S.; VAN DYKE, M. The influence of extracellular matrix derived from skeletal muscle tissue on the proliferation and differentiation of myogenic progenitor cells ex vivo. Biomaterials., v. 30, n. 12, p. 2393-2399, 2009.

TAKAHASHI, K.; KENJI, A.; NORIHIRO, T.; EISAKU, K.; TAKASHI, O.; KAZUHIKO, H.; TADASHI, Y.; TADAATSU, A. Morphological interactions of interdigitating dendritic cells with B and T cells in human mesenteric lymph nodes. Am. J. Pathol., v. 159, n. 1, p. 131-138, 2001.

TAN, J. K.; O'NEILL, H. C. Maturation requirements for dendritic cells in T cell stimulation leading to tolerance versus immunity. J. Leukoc. Biol., v. 78, n. 2, p. 319-324, 2005.

TASAKI, A.; YAMANAKA, N.; KUBO, M.; MATSUMOTO, K.; KUROKI, H.; NAKAMURA, K.; NAKAHARA, C.; ONISHI, H.; KUGA, H.; BABA, E.; TANAKA, M.; MORISAKI, T.; KATANO, M. Three-dimensional two-layer collagen matrix gel culture model for evaluating complex biological functions of monocyte-derived dendritic cells. $\mathbf{J}$. Immunol. Methods., v. 287, n. 2, p. 79-90, 2004.

TEKLENBURG, G.; MACKLON, N. S. Review: in vitro models for the study of early human embryo-endometrium interactions. Reprod. Sci,, v. 16, n. 9, p. 811-818, 2009.

TSCHOETSCHEL, U.; SCHWING, J.; FROSCH, S.; SCHMITT, E.; SCHUPPAN, D.; RESKE-KUNZ, A. B. Modulation of proliferation and lymphokine secretion of murine CD4+ $\mathrm{T}$ cells and cloned Th1 cells by proteins of the extracellular matrix. Int. Immunol., v. 9, n. 1, p. 147-159, 1997.

USHIKI, T.; OHTANI, O.; ABE, K. Scanning electron microscopic studies of reticular framework in the rat mesenteric lymph node. Anat. Rec., v. 241, n. 1, p. 113-122, 1995.

VAN NUFFEL, A. M.; CORTHALS, J.; NEYNS, B.; HEIRMAN, C.; THIELEMANS, K.; BONEHILL, A. Immunotherapy of cancer with dendritic cells loaded with tumor antigens and activated through mRNA electroporation. Methods Mol. Biol., v. 629, n. 12, p. 405-452, 2010. 
VAN PARIJS, L.; REFAELI, Y.; LORD, J. D.; NELSON, B. H.; ABBAS, A. K.; BALTIMORE, D. Uncoupling IL-2 signals that regulate $\mathrm{T}$ cell proliferation, survival, and Fas-mediated activation-induced cell death. Immunity., v. 11,n. 7, p. 281-288, 1999.

VAN VOORHIS, W. C.; HAIR, L. S.; STEINMAN, R. M.; KAPLAN, G. Human dendritic cells. Enrichment and characterization from peripheral blood. J. Exp. Med., v. 155, n. 4, p. 1172-1187, 1982.

VASSALLI, G. Dendritic cell-based approaches for therapeutic immune regulation in solidorgan transplantation. J. Transplant., v. 3, n. 15 p. 376-429, 2013.

VIAUD, S.; TERME. M.; FLAMENT, C.; TAIEB, J.; ANDRÉ, F.; NOVAULT, S.; ESCUDIER, B.; ROBERT, C.; CAILLAT-ZUCMAN, S.; TURSZ, T.; ZITVOGEL, L.; CHAPUT, N. Dendritic cell-derived exosomes promote natural killer cell activation and proliferation: a role for NKG2D ligands and IL-15Ralpha. PLoS One., v. 4, n. 3, p. 494-500, 2009.

VIK-MO, E. O.; NYAKAS, M.; MIKKELSEN, B. V.; MOE, M. C.; DUE-TØNNESEN, P.; SUSO, E. M,; SÆBØE-LARSSEN, S.; SANDBERG, C.; BRINCHMANN, J. E.; HELSETH, E.; RASMUSSEN, A. M.; LOTE, K.; AAMDAL, S.; GAUDERNACK, G.; KVALHEIM, G.; LANGMOEN, I. A. Therapeutic vaccination against autologous cancer stem cells with mRNA-transfected dendritic cells in patients with glioblastoma. Cancer Immunol. Immunother., v. 62, n. 9, p. 1499-1509, 2015.

VULCANO, M.; ALBANESI, C.; STOPPACCIARO, A.; BAGNATI, R.; D'AMICO, G.; STRUYF, S.; TRANSIDICO, P.; BONECCHI, R.; DEL PRETE, A.; ALLAVENA, P.; RUCO, L. P.; CHIABRANDO, C.; GIROLOMONI, G.; MANTOVANI, A.; SOZZANI, S. Dendritic cells as a major source of macrophage-derived chemokine/CCL22 in vitro and in vivo. Eur. J. Immunol., v. 31, n. 3, p. 812-822, 2001.

WANG, K. ZHOU, Q.; GUO, A. L.; XU, C. R.; AN, S. J.; WU, Y. L. An autologous therapeutic dendritic cell vaccine transfected with total lung carcinoma RNA stimulates cytotoxic T lymphocyte responses against non-small cell lung cancer. Immunol Invest,. v. 38, n. 7, p. 665-680, 2009.

WIETHE, C.; DITTMAR, K.; DOAN, T.; LINDENMAIER, W.; TINDLE, R. Enhanced effector and memory CTL responses generated by incorporation of receptor activator of NFkappa B (RANK)/RANK ligand costimulatory molecules into dendritic cell immunogens expressing a human tumor-specific antigen. J Immunol., v. 171, n. 8, p. 4121-30, 2003.

WILLARD-MACK, C. L. Normal structure, function, and histology of lymph nodes. Toxicol Pathol., v. 34, n. 5, p. 409-424, 2006.

WÖLFLE, S. J.; STREBOVSKY, J.; BARTZ, H.; SÄHR, A.; ARNOLD, C.; KAISER, C.; DALPKE, A. H.; HEEG, K. PD-L1 expression on tolerogenic APCs is controlled by STAT-3. Eur. J. Immunol., v. 41, n. 2, p. 413-424, 2011.

XU, R.; SPENCER, V. A.; GROESSER, D. L.; BISSELL, M. J. Laminin regulates PI3K basal localization and activation to sustain STAT5 activation. Cell Cycle., v. 9, n. 21, p. 43154322, 2010. 
YAMADA, K. M.; CUKIERMAN, E. Modeling tissue morphogenesis and cancer in 3D. Cell., v. 130, n. 4, p. 601-610, 2007.

YANAGIHARA, S.; KOMURA, E.; NAGAFUNE, J.; WATARAI, H.; YAMAGUCHI, Y. EBI1/CCR7 is a new member of dendritic cell chemokine receptor that is up-regulated upon maturation. J. Immunol., v. 161, n. 6, p. 3096-3102, 1998.

YIP. D.; CHO, C. H. A multicellular 3D heterospheroid model of liver tumor and stromal cells in collagen gel for anti-cancer drug testing. Biochem. Biophys. Res. Commun., v. 433, n. 3, p. 327-332, 2013.

ZARNITSYNA, V.; ZHU, C. T cell triggering: insights from 2D kinetics analysis of molecular interactions. Phys. Biol., v. 9, n. 4, p. 45-62, 2012.

ZHANG, H. M.; ZHANG, L. W.; LIU, W. C.; CHENG, J.; SI, XM.; REN, J. Comparative analysis of DC fused with tumor cells or transfected with tumor total RNA as potential cancer vaccines against hepatocellular carcinoma. Cytotherapy., v. 8, n. 6, p. 580-588, 2006.

ZHANG, P.; YI, S.; LI, X.; LIU, R.; JIANG, H.; HUANG, Z.; LIU, Y.; WU, J.; HUANG, Y. Preparation of triple-negative breast cancer vaccine through electrofusion with day-3 dendritic cells. PLoS One., v. 9, n. 7, p. 102-197, 2014.

ZHENG, R.; SHU, S. Immune response to cancer and its regulation in regional lymph nodes. J Surg Oncol., v. 103, n. 6, p. 550-554, 2011.

ZHOU, L. J.; TEDDER, T. F. CD14+ blood monocytes can differentiate into functionally mature CD83+ dendritic cells. Proc. Natl. Acad. Sci U S A., v. 93, n. 6, p. 2588-2592, 1996.

ZHOU, T.; CHEN, Y.; HAO, L.; ZHANG, Y. DC-SIGN and immunoregulation. Cell Mol. Immunol., v. 3, n. 4. p. 279-283, 2006.

ZIEGLER-HEITBROCK, L,; ANCUTA, P.; CROWE, S.; DALOD, M.; GRAU, V.; HART, D. N.; LEENEN, P. J.; LIU, Y. J. Nomenclature of monocytes and dendritic cells in blood.

Blood., v. 116, n. 16, p. 4-8, 2010. 